Historic, Archive Document

Do not assume content reflects current scientific knowledge, policies, or practices. 


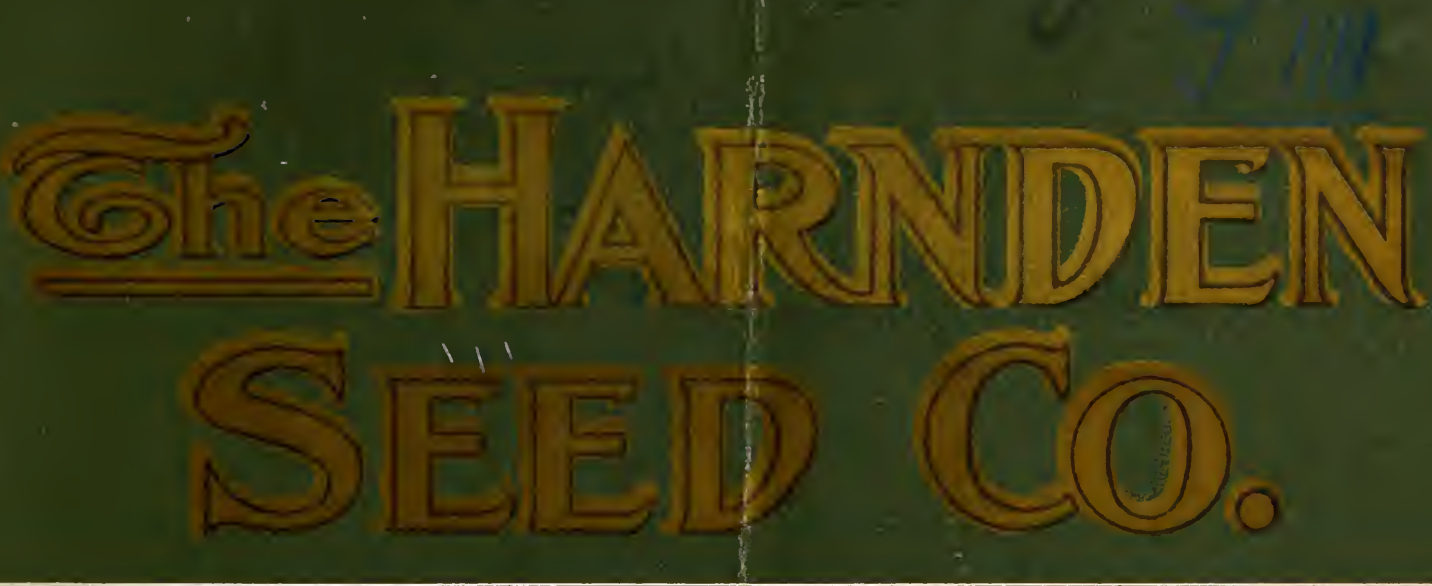


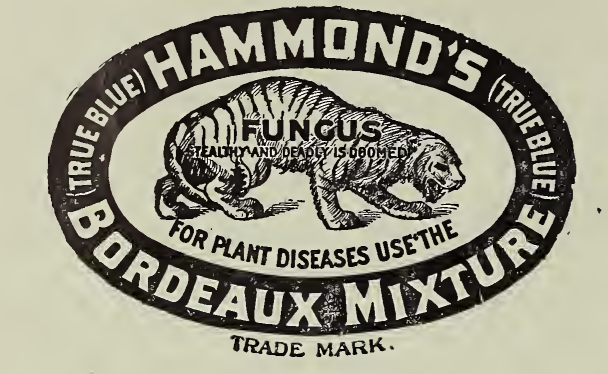

Hammond's Slug Shot

Is One of the Great Staple Remedies to Destroy Insects That Prey on Plants of All Kinds

Perforated top carton for small gardens, dusting fowls, dogs or cats 1or lice. Price, filled, $15 \mathrm{c}$.

Perforated tin screw top canister for house plants. Can be refilled. Price, $25 \mathrm{c}$.

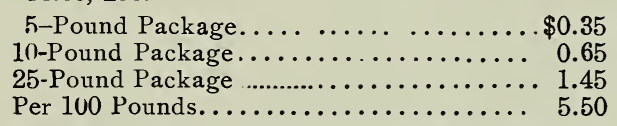

KEROSENE EMULSION_To kill hairy caterpillars. 1 Qt. 50c. Gal., \$1.60.

HELLEBORE_T/2 lb., 15c; 1 lb., 25c; 5 lbs., $\$ 1.00$.

PARIS GREEN_- $1 \mathrm{lb}$. to 50 gallons of water. $1 / 4 \mathrm{lb}, 15 \mathrm{c} ; 1 / 2 \mathrm{lb}$. 25c; 1 lb., 40c; 5 lbs. at 30c; 14, 28 and 56 lb. Keg at $24 \mathrm{c}$ per lb.

ARSENATE OF LEAD_-1 lb., 25c; 2 lbs., 45c; 5 lbs , $\$ 1.00 ; 25 \mathrm{lb}$, and $10 \mathrm{lb}$. kegs at $16 \mathrm{c} ; 2 \mathrm{lb}$ lb. and $400 \mathrm{lb}$. barrels at $12 \mathrm{r} / 2 \mathrm{c}$.

WHALE OIL SOAP_Makes an excellent wash for trees and plants where insects and Eggs affect the bark. $1 / 4$ lb. box, 10c; I $/ 2$ lb. box, $15 \mathrm{c}$.

TOBACCO PAPER_-Sure death to black and green fly, also to thrips. In fact kills everything affected by tobacco fumes. Very easy to use and not the least disagreeable. Complete instructions with each package. Price for $1 / 2 \mathrm{lb}$. can, 75c. Not prepaid.

TOBACCO DUST-For fumigating. 10c per lb.; 3 lbs for 25c; $\$ 3.50$ per 110 lbs.

\section{The French Bordeaux Mixture}

\section{In Fine Pulp or Liquid Form}

The finest and best article of its kind made in America. Ready for immediate use. Works freely, without clogging, in any spraying machine. To be diluted 25 to 50 times with water and sprayed. The uniformity of its consistence permits of very fine spray and consequent large economical distribution of a small quantity evenly over a large area of surface. Prevents black rot, mildew and rust. Destroys fungous growth on vegetables. $1 \mathrm{Qt}$. can, $50 \mathrm{c} ; \mathrm{Gal}$., $\$ 1.50$

TOBACCO DUST_Fine for spraying. 10c per lb; 3 lbs. for 25c; $\$ 3.50$ per $100 \mathrm{lbs}$.

HAND DUST SPRAYER-For applying. $\$ 1.00$ each.

TOBACCO EXTRACT-For vaporizing and spraying. Destroys Aphides and red spiders. $30 \mathrm{c}$ per $1 / 2 \mathrm{pt}$.; $50 \mathrm{c}$ per $\mathrm{pt}$.

GRAPE DUST_Destroys mildews, prevents blights in greenhouses or hotbeds. $5 \mathrm{lb}$. pkg., $40 \mathrm{c}$.

SULPHO TOBACCO SOAP_-3 oz. cake, 10c; 8 oz., 20c. Not prepaid. If by mail, add lc per ounce.

SANITINE-The best ant, roach and insect exterminator known. Very easy to use and not poisonous. Is clean and has an agreeable odor. It is also used as a disinfectant. Pint bottle, 50c. Not prepaid.

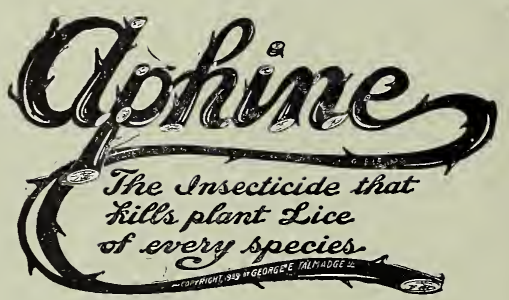

Prices as follows:
APHINE_The insecticide which kills green, black white and Belgium scale, red spider, thrip and mealy bug. In fact it does better work than any other insecticide known. Recommended by the leading entomol. ogists of the country. Full directicns with each package. and white fly, brown,

$x / 2$ pint cans ................. $\$ 0.40$

Pint cans....................... 0.65

Quart cans...............................

Gallon can.................... 2.00

NOT PREPAID

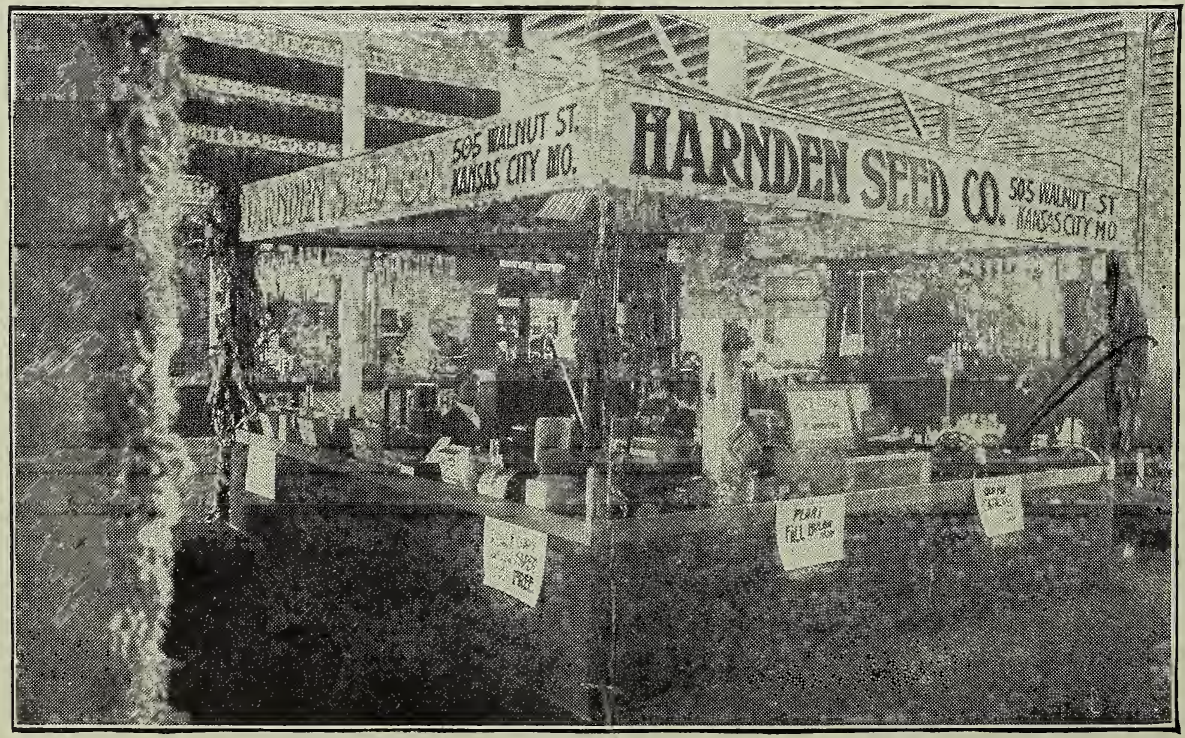




\section{Harnden Seed Co. walnut street Kansas City, Mo.}

Date___ Forward by $\left(\begin{array}{l}\text { State whether wanted by } \\ \text { Mail, Express of Freigbt }\end{array}\right)$

Please Do Not Write Here

Name

Street, P. O. Box or

Rural Delivery

Post Office

Express Office ( $\left(\begin{array}{l}\text { If Different } \\ \text { From P. O. }\end{array}\right)$

County

State

Amount Enclosed 


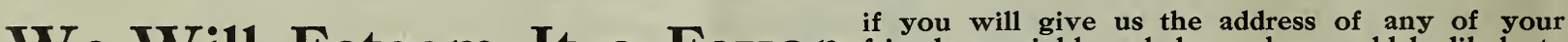 if you will give us the address of any of your
friends or neighbors below who would be likely to buy seeds or other goods in our line.}

\section{PLEASE DO NOT WRITE IN THE SPACE BELOW}

Flower Seed Order Filled

Vegetable Seed Order Filled

Agricultural Seed Order Filled

Sundry Order Filled

Plant Order Filled

Shipped

\section{Date}

“

“

66

66
By

“

“

“

“ i 


\section{The Harnden Seed Co.'s}

Annual Catalogue

For I9II

\section{ANNOUNCEMENT}

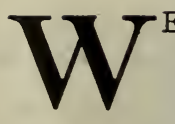

desire to present our annual catalogue for your inspection, and beg to say that we are again able to offer you a complete line of field, garden and flower seeds grown by the best growers in this country and in Europe. Our stock is the finest we can buy, which assures you of a good crop.

Our facilities for handling our business this year are better than ever before. We have arranged for larger warehouse space, which allows us to buy and store greater amounts of seed. This of course means lower prices on all seeds which were not injured by the bad weather last spring and summer. Some of the seeds imported from other countries have been injured in this way; also a heavier tariff has been imposed. Notwithstanding these handicaps, we offer you our complete stock of all seeds at reasonable prices and know full well that your results will be more than satisfactory.

We have created a new department in our business, preparations for which have been going on for three years. This new department is our Pedigreed Seed Corn line, one that is complete and is as far advanced as science and sense teaches us. We have obtained for our work several of the leading varieties and these we have bred up for yielding qualities. They are pure and of pedigreed stock. Our breeding plots are segregated and cannot be mixed by other corn about them. You will find on another page a complete account of our Pedigreed Seed. We refer you to it for further information.

To our patrons in Kansas City and nearby places we are pleased to announce that we have opened a second retail store at 1418 Grand Ave., Kansas City, Mo. We are carrying a full line of field, garden and flower seeds at our new place, also a full line of bulbs, shrubs, poultry supplies and. remedies. We have further made arrangements with the Central Coal and Coke Co. of this city to sell their different grades of coal and we will be pleased to receive your orders, which will have our careful attention.

This new store is run in connection with our old stand at 505 Walnut Street. The demand has increased so within the last few years for a seed store farther up town that we deemed it wise to obtain the store formerly occupied by the Fish Seed, Feed and Coal Co., whom we have succeeded. Your patronage is solicited and our reliability as seedsmen is our guarantee that you will get only the best grades of seed at a reasonable figure.

We have done business here for twenty-five years, always striving to give the best for the lowest price.

Our garden seeds, which for the past years have given such satisfaction, are even better than ever before. Our selections are of the best and twenty-five years' experience has given us the ability to make these selections.

Flower seeds are one of our strongest features and our varieties and mixtures cannot be equaled by any seed company. These we offer you and for further and more definite information refer you to our Flower Seed Department which you will find in this book.

We thank you far past favors and hope to be in receipt of your future orders, which we assure you will have our careful attention.

You no doubt received our paper, The Kansas City Seedsman. This we hope to make the best thing of its kind ever published and it will be sent to you free of charge each time it is issued, which will be six times per year. Tell your friends about this paper or send us their names and we will send it to them regularly.

Your patronage is solicited and we guarantee to give you fair and honest treatment. Our stock is good, our prices right-your orders will be appreciated.

\section{THE HARNDEN SEED CO.}

Kansas City, Mo., January, 1911.

\section{Our Guarantee}

So many different conditions may arise regarding the germination or growth of seeds, bulbs or plants, such as planting too shallow, or too deep, destruction by insects, frosts, chemical changes, etc., that we are forced to sell our seeds under the non-guarantee rule used by all seedsmen, viz: The Harnden Seed Company, while they exercise the greatest care in the selection of their seeds, give no warranty, express or implied, as to description, purity, productiveness of any seeds, bulbs or shrubs they send out, and they do not in any way guarantee them to grow or be responsible for the crop. If the purchaser does not accept the goods on these terms they are at once to be returned. 


\section{6}

\section{Tested Vegetable Seed}

WE TEST ALL SEED BEFORE SHIPMENT IS MADE

SEEDS BY MAIL-We pay postage on all Vegetable and Flower seeds offered in this catalogue by packet, ounce, quarter pound, pound, pint or quart, unless otherwise noted. We guarantee safe delivery by mail, postage prepaid.

SEEDS BY EXPRESS OR FREIGHT - When Seeds are ordered sent by Freight or Express, 8 cents for a pound, 8 cents for a pint, and 15 cents for a quart may be deducted from prices in this catalogue for these quantities, as purchaser pays express and freight charges when shipment is received.

PECK, BUSHEL AND BARREL LOTS-The Freight or Express charges must be paid by purchasers when shipment is received.

MARKET GARDENERS OR OTHER LARGE PLANTERS requiring larger quantities of Seeds than are here quoted are invited to write for Our Special Price List. This we cannot send to private gardeners, as it is intended only for those who grow for market. In wrîting, please state whether you are a Market Gardener, Florist or Dealer in Seeds.

It pays to order heavy seeds and large quantities by Freight or Express, but it must be done somewhat earlier in the season to insure delivery on time.

IN REMITTING Send Money by Express, Kansas City Draft, Registered Letter or P. O. Money Order; we also take postage stamps to any amount. We do not send goods C. O. D. unless 50 per cent of the money is sent with order.

\section{Discounts}

1-On Seeds in Packets and Ounces:

Purchasers may make selections of seeds in Packets and Ounces at the following discounts:

When sending $\$ 1.00$, to the value of $\$ 1.25$.

When sending $\$ 2.00$, to the value of $\$ 2.50$.

When sending $\$ 3.00$, to the value of $\$ 3.75$.

When sending $\$ 4.00$, to the value of $\$ 5.00$.

When sending $\$ 5.00$, to the value of $\$ 6.25$.

These discounts do not apply to seeds sold in larger quantities than one ounce, nor on collections, bulbs, plants, or tools. For all of these the published prices must be sent.

2-On Seeds in Bulk.

From catalogue prices by the $1 / 4$ pound, pounds, peck or bushel (except. on grass, clover and other field seeds), when cash is sent with order, purchaser may deduct 5 per cent on an order of from $\$ 3.00$ to $\$ 5.00$, and 10 per cent on an order from $\$ 6.00$ to $\$ 10.00$.

\section{ARTICHOKE}

Culture-Sow early in the spring at intervals of four inches, in drills one foot apart, transplanting the following spring to permanent beds in drills three feet apart each way.

Large Green Globe-Pkt., 5c.; oz., 30c; x/4 lb., $\$ 1.00$.

\section{Jerusalem Artichoke}

This variety is cultivated for its tubers, which are especially valuable for hog food. Plant in rows three feet apart and two feet in the rows; cover about four inches deep. Will produce 350 to 500 bushels per acre. Per peck, 50c; bu., $\$ 1.50$; not prepaid.

\section{5c WORTH OF SEEDS EXTRA.}

With every dollar's worth ordered in pkts. and ounces. This does not apply to $1 / 4 \mathrm{lb} ., 1 \mathrm{lb}$., pints, quarts, pecks, or tools. For these net price must be sent.

\section{ASPARAGUS}

Culture-The permanent beds should be prepared by deep plowing or spading and thoroughly enriching the ground with stable manure or other fertilizers. Set out in beds 5 feet wide, three rows in a bed, the outer being each 1 foot from the edge, and 12 inches in the row; set the plants with roots well spread, about 6 inches below the surface. After the plants are well started, give frequent and thorough cultivation. In? autumn, after the tops are fully ripe and yellow, they' should be cut and burned and a good dressing of manure applied, and in the spring forked in, after which one quart of salt to each square rod put on the ground will be found very beneficial. The next season the bed may be cut over two or three times, but if this is done, all the roots, no matter how small, should be cut, and after the final cutting, give a good dressing of manure and frequent cultivation. For market on a large scale, set 4. feet apart one way and $1 \mathrm{x} / 2$ the other; to grow plants from seed, sow in drills 1 inch deep in rows 1 foot apart; soak the seed before planting.

Argenteuil-Grows to large size. Vigorous, free from rust. Delightful flavor. Per packet, 5c; oz., 10c; $\mathrm{r} / 4 \mathrm{lb}$., 25c; 1 lb., $75 \mathrm{c}$.

Conover's Colossal-A productive and popular sort, and probably as good as any. Pkt., $5 \mathrm{c}$; oz., 10c; $1 / 4 \mathrm{lb}$., 20c; 1 lb., 50c.

Palmetto-Earlier than the Colossal. Pkt., 5c; oz., $10 c ; x / 4$ lb., 20c; 1 lb. $60 c$.

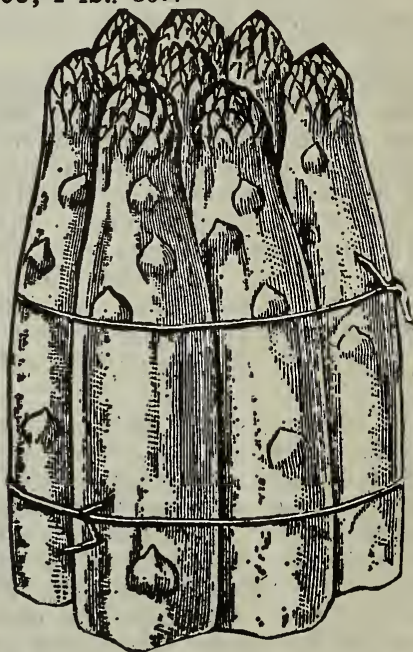

Columbian Mammoth White.

Columbian Mammoth White-A new variety with white shoots, stay white without earthing up or blanching. Pkt., 5c; oz., 10c; $1 / 4$ lb., 20c; 1 lb., 60c.

Asparagus Roots-By purchasing good, strong roots, two years, time is saved. At prices given by express, purchaser pays the charges when received.

STRONG TWO-YEAR-OLD ROOTS.

By Mail postpaid By Express not paid

Doz. $100 \quad 100 \quad 1000$

Columbian Mammoth White ..25c $\$ 1.35 \quad \$ 1.00 \quad \$ 5.50$

Palmetto $\ldots \ldots \ldots \ldots \ldots \ldots \ldots \ldots 25 \mathrm{c} \quad \mathbf{1 . 3 5} \quad \mathbf{1 . 0 0} \quad \mathbf{5 . 5 0}$

Conover's Colossal ..........25c $1.35 \quad 1.00 \quad 5.50$

50 at the 100 rate. 500 at the 1,000 rate. Special prices on larger quantities.

Asparagus Culture-A book giving, all possible details as to growing, soil, marketing, canning, etc., for home use or market; cloth, $60 \mathrm{c}$, postpaid. 


\section{BEANS}

\section{Dwarf or Bush Varieties}

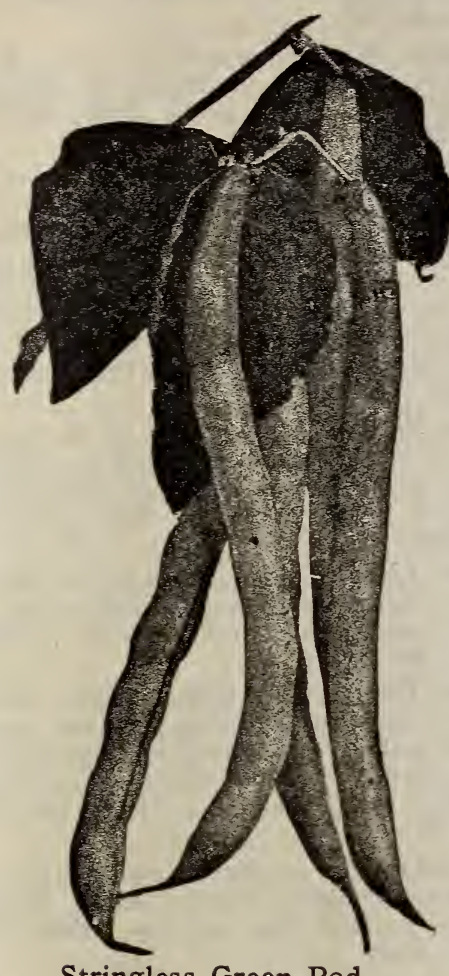

Remember the Prices on Beans - Pints and quarts are prepaid. If sent with larger order by express or freight, deduct $8 \mathrm{c}$ per pint and $15 \mathrm{c}$ per quart.

Culture - The best soil adapted is a light, rich, well-drained loam, which has been manured for a previous crop; do not plant before the ground becomes dry and warm; drop the seed in drills from 2 to 3 feet apart, leaving - two to four plants to the foot of row; cultivate them frequently up to the time of blossoming, but never disturb them when the ground or plants are wet with rain or dew; beans should be cultivated very shallow, as any cutting of roots after the plants come into bloom is liable to cause the blossoms to blast.

Stringless Green Pod.

\section{Green Podded Varieties}

Stringless Green Pod (Burpee's)-Earliest Green Podded Bush Bean. For either the market or home garden, no other green podded bean can be more highly recommended. It is very early. The pods are a rich green, very round and straight, five inches long. The pods are tender, bright and of the finest flavor, entirely stringless. Pkt., 10c; pt., 25c; qt., 45c; pk., $\$ 1.75$.

Giant Stringless Green Pod-A very productive variety, pods long, straight, of a very handsome appearance. A few days later than Stringless Green Pod. Pkt., 10c; pt., 25c; qt., $45 \mathrm{c}$; pk., $\$ 1.75$.

Full Measure-Produces a round, stringless green pod. The variety is early and remarkably prolific for an early sort. The pods are perfectly stringless and the quality is first class. The pods usually grow from 6 to 7 inches in length and $1 / 2$ of an inch in diameter, making them nearly as large in diameter as Burpee's Stringless Green Pod and somewhat longer. They may not be quite as early as Burpee's Stringless Green Pod but the pod is smoother and the plant is more hardy and productive and only a very few days later. Pkt., $10 \mathrm{c}$; pt., 25c; qt., $45 \mathrm{c}$; pk., $\$ 1.50$.

Extra Early Round Pod Red Valentine-For snaps there is nothing superior to this variety among the older green podded sorts. These plants are of dwarf, compact bush growth, fifteen to eighteen inches high; very prolific, hardy and early in maturing. Pods medium length, curved cylindrical, with crease in back; fleshy, crisp and tender. Pkt., 10c; pt., 25c; qt., 40c; pk., \$1.50.
Extra Early Yellow Six Weeks-Seeds yellowish drab, pods long, straight and when young of good quality. Pkt., 10c; pt., 25c; qt., 40c; pk., \$1.25.

Longfillow-Vigorous in growth, 16 inches tall, bearing abundance of pods 5 to 6 inches long, round, slightly curved, stringless when young, of good quality. Seed small, long, color mostly a dark red relieved by blotches and markings of a lighter shade. Pkt., 10c; pt., 25c; qt., $45 \mathrm{c} ; \mathrm{pk} ., \$ 1.50$.

Bush Lima (Burpee's)-The bushes grow from 18 to 20 inches high, of stout growth and always erect. It is an immense yielder, each bush bearing from 50 to 200 large, handsome pods, well filled with very large beans, which are identical in size and luscious flavor to the well-known large Pole Limas. Pkt., 10c; pt., 30c; qt., $45 \mathrm{c} ; \mathrm{pk} ., \$ 1.75$.

Bush Lima (Henderson's)-Grows without poles in compact bush form, about 18 inches high. Very productive; two weeks earlier than any of the Pole Limas. Pkt., 10c; pt., 25c; qt., 40c; pk., \$1.75.

\section{Wax Podded Varieties}

When not otherwise priced are each, per pkt., 10c; per pt., 30c; per qt., $45 \mathrm{c}$; postpaid. Per peck, $\$ 1.75$, not prepaid.

Dwarf Golden Wax-Old standard variety; seeds nearly round, purple and white; pods nearly straight, broad, flat, golden yellow, very fleshy and wax-like, with short green point.

Improved Prolific Black Wax-Beans small, jet black; pods round, medium length, curved, fleshy, and of a clear waxy yellow color, with long, slightly curved point. This bean is more extensively used by the market gardeners than any other variety of the wax sort.

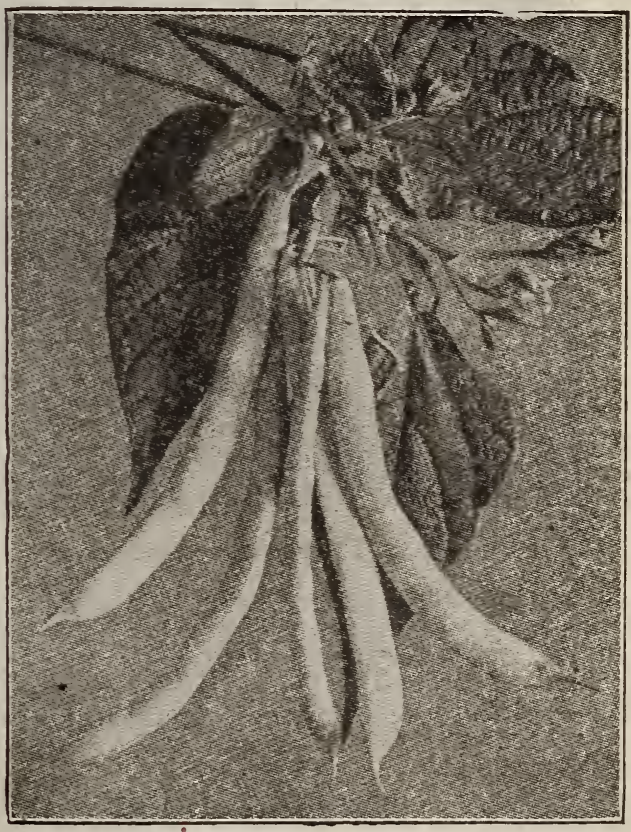

Dwarf Golden Wax.

Wardwell's Kidney Wax-Ripens about as early as the Golden Wax; vines large and strong; handsome golden-yellow, long flat pods, which are almost entirely free from rust and spots.

New Round Pod Kidney Wax Bean-This bean is closely allied to the popular Wardwell's Kidney Wax, differing from that variety in that the pod is perfectly round, somewhat longer and entirely stringless. This new sort has great merit and is destined to become one of great popularity with the market gardeners. 


\section{Wax Beans-Continued}

Currie's Rust-Proof Black Wax-We recommend this to our market gardeners as an especially good Wax Bean. The pod is of a rich yellow color, but is a flat pod instead of a round pod, fully as tender, brittle and stringless, and comes nearer being an absolutely rustproof bean than any other wax variety.

Davis' Kidney 'Wax-This plant is a vigorous grower, carrying the pods well up from the ground. The pods are long, straight, oval, of clear waxy-white color and handsome, often growing to a length of seven to eight inches, are quite stringless and of fine flavor.

Pencil Pod Black Wax-Early, hardy, very prolific and of excellent quality. Pods are long, straight and round, like a pencil, of a bright yellow color, tender, brittle and absolutely stringless. The seeds are long, round and rather small; color black.

Jones' Stringless Wax-A white seeded variety with round, stringless pods of unsurpassed beauty and quality. Nearly a week earlier than any strain of black wax. The pods are long, perfectly round, and exceptionally solid, of a delicate light color, perfectly stringless, showing no coarseness even when past their prime.

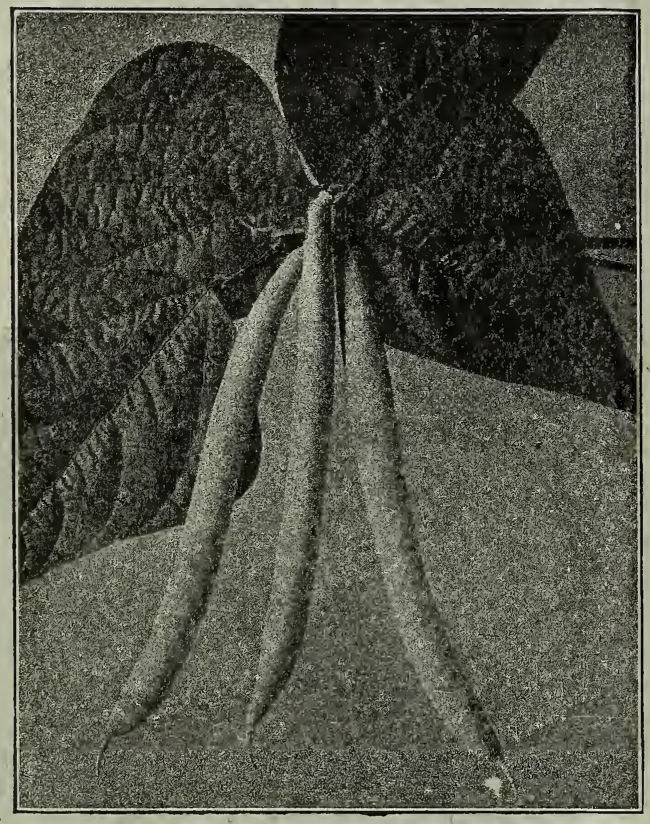

Stringless Refuge Wax (Keeney's).

Stringless Refuge Wax (Keeney's)-Ten days to two weeks earlier than the Round Pod Thousand to One Refugee, and is very near, if not quite as prolific as this very prolific cropper. The pods are the same size and shape and are of exceptionally fine quality. The color is a light, bright yellow and the pod is perfectly stringless at all stages of development. This is probably the most prolific of all the Round Podded. Wax Beans known to the trade at the present time and is used very extensively by canners who want both quantity and quality.

\section{Pole or Running Bean}

Lazy Wife-Pods produced in great abundance; measure 6 to 8 inches in length; broad, thick, fleshy and entirely stringless. Each pod contains from 6 to 8 round white beans. Pkt., 10c; pt., 30c; qt., 45c; pk., $\$ 1.75$.
Dutch Case Knife-Earliest pole bean; pods long and flat; beans white, of excellent quality, green or dry. Pkt., 10c; pt., 25c; qt., 40c; pk., \$1.50.

Horticultural or Speckled Cranberry-A showy bean, maturing in eighty days. Pods green, dashed with red, valued either as a snap or for shelling. Pkt., 10c; pt., 25c; qt., 40c; pk., \$1.75.

Early Golden Cluster Wax-A desirable sort. Pods six to eight inches long, borne in abundant clusters, each containing from three to six pods. Pkt., 10c; pt., 35c; qt., 50c; pk., \$2.25.

Speckled Cut Short or Corn Hill-Will grow when planted among corn, without poles; good cropper and very popular. Pkt., 10c; pt., 30c; qt., 45c; pk., $\$ 1.75$.

Kentucky Wonder, or Old Homestead-A very prolific sort, producing its long pods in large clusters. The pods, when young, are nearly round, of the best flavor and are most excellent for snaps. This is one of the best and most profitable beans for the market gardener. Pkt., 10c; pt., 30c; qt., 45c; pk., \$1.75.

Kentucky Wonder Wax-Very similar to the green podded variety except in color of pod which is a bright golden yellow, long, well filled. Good for either snap or shell bean. Strong vigorous vines. Pkt., 10c; pt., 30c; qt., 50c; pk., \$2.00.

King of the Garden Lima-Pods large and frequently contain from five to six large beans. Similar to the Large White Lima, but matures much earlier. Pkt., $10 \mathrm{c}$; pt., $30 \mathrm{c}$; qt., $45 \mathrm{c}$; pk., $\$ 1.75$.

Small White Lima, Carolina or Sieva-Vines vigorous, with many short branches, so that they are sometimes grown without poles; very early and productive with small, smooth, dark green leaves; pods curved, short, flat; seed white, small and flat. Pkt., 10c; pt., $25 \mathrm{c}$; qt., 40c; pk., \$1.75.

Siebert's Early Lima-The earliest Lima bean for home garden or market. Short pods, contain from 4 to 5 beans, enormous yielder, fine quality. Pkt., 10c; pt., 30c.; qt., $45 \mathrm{c}$; pk., $\$ 1.75$.

\section{MANGEL WURZEL BEETS}

\section{The Most Nutritious, Fattening and Best Winter Food for Stock}

Pkt., 5c; oz., 10c; I/4 1b., 15c; 1 lb., 35c, prepaid. By express, not prepaid, $25 \mathrm{c} \mathrm{lb}$. Write for Prices on Large Lots.

Culture-Sow the seed during April and not later than the last of May. Plant 1 inch deep in drills from 2 to $2 \frac{1}{2}$ feet apart, dropping from 6 to 10 seeds to the foot, which will require from 6 to 10 pounds to the acre. When the plants are 3 inches high, thin out with the hoe to 10 to 12 inches. Cultivate well and often, but discontinue as soon as the "roots have commenced to form. The roots should be harvested and stored in pits or cellar when ripe, for if left they may start into fresh growth.

Harnden's Mammoth Long Red-The roots are very large, uniformly straight, and heavy cropper. It is the best long red mangel and of the greatest value for stock feeding.

Champion Yellow or Orange Globe-Much esteemed for its smooth, globe-shaped roots, which grow to a large size; flesh white; an excellent keeper.

Golden Tankard-One of the finest mangels in cultivation; used extensively in England for dairy farming; of almost cylindrical shape. Color deep yellow. 


\section{GARDEN BEETS}

Our prices are for seeds, postpaid, by mail. If ordered by express or freight, remember to deduct 8 cents per pound from prices quoted.

\section{Harnden's Selected Stock}

\section{French Grown Beet Seed}

Culture-Cultivation has more effect in the quality of this than most any other vegetable. To be sweet and tender it must be grown quickly, a result that can only be obtained by having the soil worked deep, made light and rich by the application of well-rotted manure. Sow in drills 18 inches apart and 1 inch deep; thin to 4 inches apart. For winter use, the turnip variety may be shown in June. One ounce to 60 feet of drill; 4 pounds per acre.

Harnden's Early Market-The earliest beet ever brought on our market, maturing for two seasons earlier than any other beet here. Tops small, making it fine for bunching. Skin and flesh deep blood red, fine grained and tender. See cut taken from a photograph. Pkt., 5c; Oz. 10c; I/4 1b., 30c; 1b., \$1.00.

Detroit Dark Red-Tops exceptionally small and uniformly upright; roots are perfect turnip shape with small tap roots. The principal fault with most turnip beets is the occasional appearance of white rings, but by careful selection this has been overcome and will be found to be one of the deepest red beets. Quality of the very best, sweet, tender. Gardeners can safely plant it largely. Pkt., 5c; oz., 10c; r/4 1b., 25c; 1b., 75c.

Improved Early Blood Turnip-This is an improved strain of the old Blood Turnip Beet, having smooth, round roots of medium size, with dark red flesh, fine grain, very sweet, excellent for summer and autumn use. Pkt., 5c; oz. 10c; I/4 lb., 20c; 1 lb., 50c. son that has tried this superb beet pronounces it one of the best beets in cultivation. Almost round, leaves small, dark rich crimson, with rings of lighter hue; flavor delicate, rich and sugary. Pkt., 5c; oz., 10c; 1/4 lb., 25c; 1 lb., 75c.

Crimson Globe-Is a very fine variety for early or main crop, medium size, almost globe shape, smooth and free from rootlets; flesh dark rich red. Pkt., 5c; Oz., 10c; I/4 1b., 25c; 1 lb., 75c.

\section{Swiss Chard Beet or Summer Spinach}

A distinct vegetable and much superior to the common beet for greens and equal to spinach. It must be remembered, however, that the roots are of no value as beets. Sow early in the spring in rows 16 inches apart and the seedlings afterwards thin out to 6 inches in the row. Pkt., 5c; oz., 10c; I/4 1b., 20c; lb., 60c.

\section{Sugar Beets}

Pkt., 5c; oz., 10c; I/4 lb., 15c; 1 lb., 40c, prepaid. By express, not prepaid, 35c per lb.

Vilmorin's Improved Sugar-An improved French sort, medium, containing a large percentage of sugar Chiefly used by sugar beet growers. Grows below the surface.

Lane's Imperial Sugar-This beet grows to a large size, yields almost as much in bulk as the best mangel, and contains a large percentage of sugar. Roots smooth, free from small rootlets, broad at the shoulder, and gradually taper to the base. Grows partially above ground. Smooth, whitish-green skin, snow-white flesh.

Business is good. We have branched out and you can get Harnden's seeds at our up-town store, 1418 Grand Ave., and 505 Walnut St., Kansas City.
Edmand's Early Blood Turnip-A selected strain of blood turnip beet; deep blood red in color, with small tops; handsome appearance, favorite with market gardeners as a late sort. Pkt., 5c; Oz., 10c; r/4 lb., 20c; 1b., 65c. Extra Early Egyptian-Roots very dark red, tender and sweet, rounded on top. The seed we offer is a special selection of the darker and most perfect roots with small tops. Pkt., $5 \mathrm{c} ;$ oz. 10c; I/4 1b., 25c; 1 1b., $75 \mathrm{c}$.

Crosby's Egyptian-An improved strain of the Egyptian. Instead of being flat, the roots are smooth and round in shape; of finer quality, combined with the same extra early maturity. Pkt., 5c; Oz., 10c; $1 / 4 \mathrm{lb}$., 25c; 1 1b., 75c.

Eclipse-Another very fine early variety with globe-shaped roots; flesh dark-blood, zoned with a lighter red, very sweet, crisp and tender, especially when young. Pkt., 5c; Oz., 10c; I/4 lb., 25c; 1 lb., 75 c.

Dewing's Early Bood Turnip-Deep blood red, turnip shape. Pkt., 5c; oz., $10 \mathrm{c} ; \mathrm{I} / 4$ lb., 20c; 1 lb., 60c.

Long Smooth Dark Red-An excellent variety, flesh dark red, zoned with lighter shades, large size, remaining sweet and tender until spring. Pkt., 5c; oz., 10c; $1 / 4$ lb., 20c; 1 lb., 60 c.

Electric Beet-The best all around beet for market garden purposes ever introduced on our market. Every per-

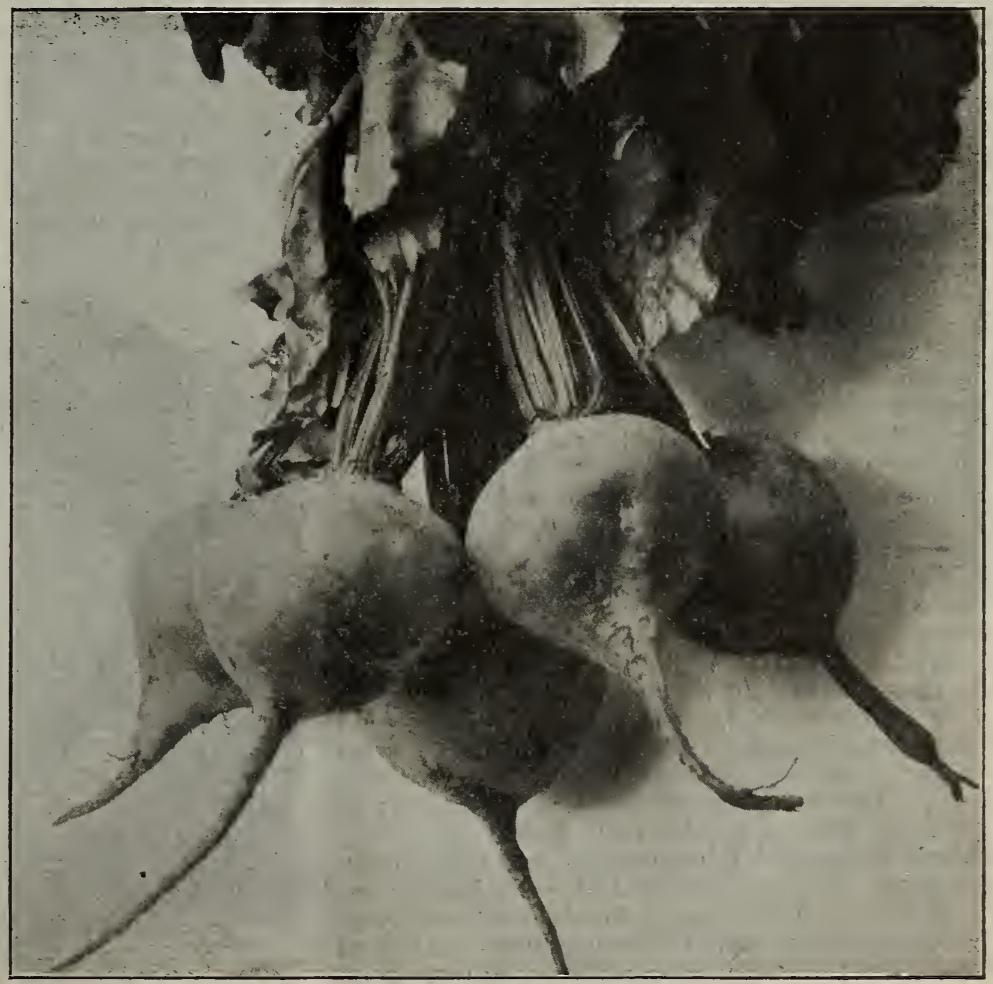

Harnden's Early Market. 


\section{Harnden's American Grown Cabbage Seed}

\section{A Word About Cabbage Seed}

Never in the history of the seed trade has the cabbage seed been so short. Both in this country and Europe the crop has been almost a failure, and we have made these prices as reasonable as possible. Orders will be filled without any advance as long as present stock lasts. If wanting cabbage in larger quantities

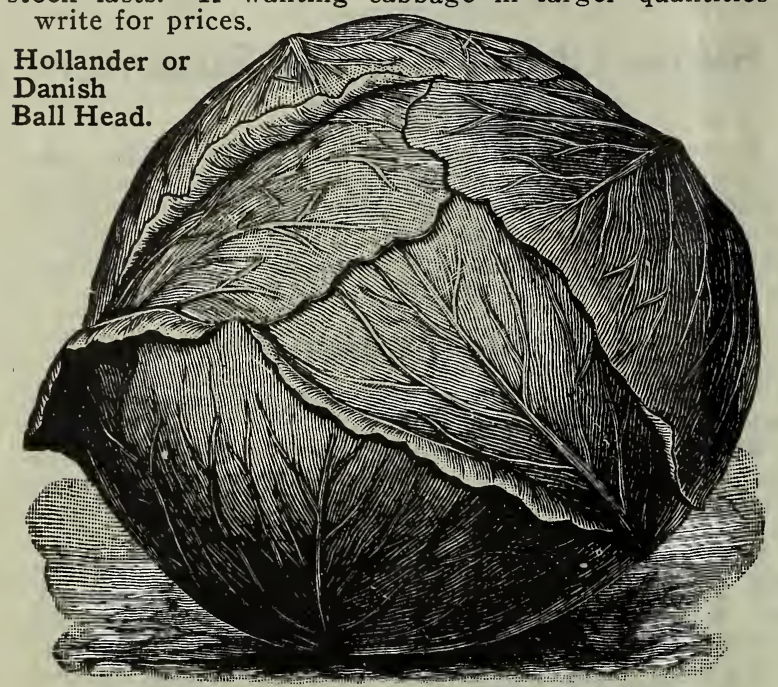

\section{Cabbage and Cauliflower Culture}

Book giving directions how to grow, etc., postpaid, $60 \mathrm{c}$.

Culture-The cabbage, to be well grown, requires a deep, rich loamy soil. For early use, sow the seed in hot-beds in February or March, or it may be sown about the middle of September, and the plants wintered over in cold frames. Transplant in spring, as soon as the ground can be worked, in rows 2 feet apart, and the plants 18 inches apart in rows. For late or winter use, the seed should be sown in May, and the plants set out in July, $21 / 2$ by 3 feet. Prices are prepaid.

Extra Early Jersey Wakefield-The earliest and hardiest heading of first early cabbages. Most gardeners depend upon it for the bulk of their extra early crop. Its exceeding hardiness not only to resist cold weather, but other unfavorable conditions, insures the greatest likelihood of profitable and satisfactory results. Head conical, very compact, solid and of excellent quality. Selected American grown, per pkt., 10c; oz., 35c; 2 oz., 60c; r/4 lb., 90c; 1b., \$3.50. Imported, Pkt., 5c; Oz., 20c; 2 oz., $35 c ; 1 / 4$ lb., 60c; 1 lb., \$2.00.

Harnden's Large Heading Wakefield-Similar in every respect to the Jersey Wakefield except that it is very much larger, and not quite so early. Heads not quite as much pointed. Pkt., 5c; oz., 20c; I/4 lb., 60c; 1b., \$2.00.

Early Summer, Selected Stock-About 10 days later than the Early Wakefield, but being fully. double the size, it may be classed as decidedly the best large early cabbage, and is deservedly popular with market gardeners. Equal in weight to most of the late varieties. Keeps a long time withont bursting. Heads round, not pointed. Pkt., 5c; $1 / 2$ Oz., 10c; oz., 20c; I/4 lb., 60c; 1b., $\$ 1.60$.

Fottler's Improved Brunswick-This has proven to be a most excellent acclimated second early variety. It is low on the stump, heads solid and comfact, weighing from ten to fifteen pounds each, and is sure to head. From seed sown in March good size heads can be marketed in June. A very valuable variety. Pkt., 5c; oz., 20c; r/4 lb., 65c; lb., \$2.25.

Dark Red Erfurt-Earlier than the Red Dutch. Excellent sort for pickling. Pkt., 5c;0z., 25c; I/4 lb., 65c.

Improved Red Dutch (Red Drumhead)-Used exclusively for pickling; heads flat and solid; color, deep purple. Pkt., 5c; Oz., 25c; $1 / 4$ lb., 65c.

Early Ulm Savoy-Very early and of fine quality. Heads round, beautifully crumpled, solid and of a deep green color. Pkt., 5c; 0z., 25c; I/4 1b., 65c.

Hollander or Danish Ball Head Cabbage-This splendid variety is remarkable for its solidity and grand keeping qualities. The heads, although not quite so large as Premium Flat Dutch, are equally as heavy and superb in quality. Pkt., 10c; $1 / 2$ oz., 15 c; 0z., 25 c; 2 ozs., $45 \mathrm{c} ; \mathrm{r} / 4$ 1b., 75c; lb., \$2.75.

Harnden's Premium Large Late Flat Dutch-We have taken great pains in the selection of this strain, and have sold it to our market gardeners for a number of seasons. It has given universal satisfaction to every one who has tried it, maturing well in our climate, and produces large and compact heads. For general crop this variety cannot be excelled. Pkt., 5c; oz., 20c; I/4 lb., $60 \mathrm{c} ; 1 \mathrm{~b}$., $\$ 2.25$.

St. Louis Late Market-An extremely large and solid heading variety, well suited for fall and winter. It forms large, handsome heads which will keep in the best condition for a long time. We recommend this sort for markets that require a very solid head. Pkt., 5c; 0z., 25c; $\mathrm{r} / 4 \mathrm{lb}$., $75 \mathrm{c}$; 1b., \$2.25.

We offer the following standard sorts, postpaid. Pkt., 5c; oz., 25c; I/4 lb., 60c; lb., \$2.00.

Early Spring, Early Winningstadt, Early Flat Dutch, All Seasons, Louisville Drumhead, Succession, Surehead, Early Drumhead, Large Late Drumhead.

\section{Gress}

Curled or Pepper Grass-This small salad is much used with Lettuce, to the flavor of which its warm, pungent taste makes a most agreeable addition. Sow thickly in drills sixteen inches apart. Pkt., 5c; oz., 10c; I/4 lb., 20c; lb., 50c, postpaid.

True Water-This is quite a distinct variety of cress, and only thrives when its roots and stems are submerged in water. The seed should be sown and lightly covered in gravelly, mucky lands, along the borders of small streams. Pkt., $10 \mathrm{c}$; oz., $30 \mathrm{c} ; \mathrm{x} / 4 \mathrm{lb}$., $\$ 1.00$.

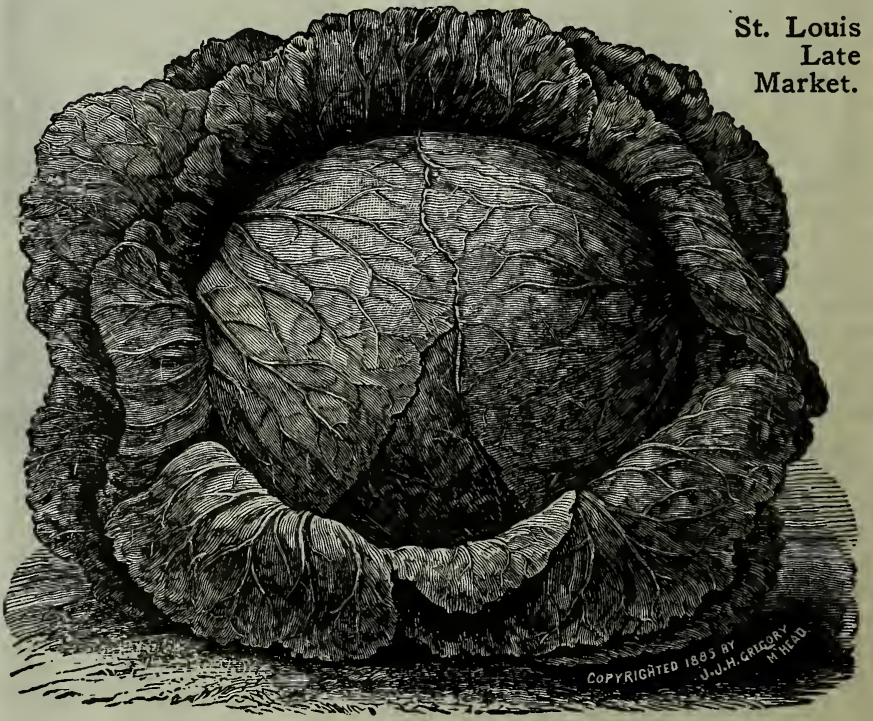




\section{CUCUMBERS}

The Klondike Cucumber-Has proven in every way a valuable acquisition, producing fruit for every purpose for which cucumbers are used; averaging from 6 to 8 inches in length; uniform in size; dark green color; retaining its color, and a very prolific yielder. One of the best for home gardens, and a good market garden sort. Pkt., 5c; oz., 15c; I/4 1b., 35c; 1b., \$1.00.

Japanese Climbing-Vines are of healthy, vigorous growth, with rich dark green foliage, and throws out strong, grasping tendrils, which enable it to climb trellis, wire netting, brush or any other suitable support. Of large size, cylindrical shape; flesh pure white; skin dark green, turning to brown and netted when

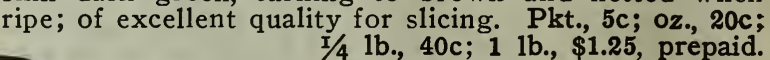

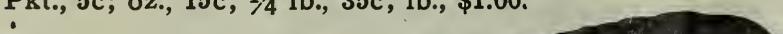
Improved L o n g Green - A standard late sort; fruit dark green. Pkt., 5c; oz., 15c; r/4 lb., 35c; 1b., \$1.25.

Improved Arlington White Spine-This is the strain so universally popular for growing under glass, the earliest and by far the best forcing strain; uniform in size, color a rich green, with light green spines. It is not only the best for forcing, but is unsurpassed for open ground. Pkt., 5c; Oz., 15c; $1 / 4$ lb., 35c; 1b., $\$ 1.00$.

Livingston's Evergreen - An improved type of Evergreen; fruit medium size; rich, deep green skin; a favorite early variety; fine for table use. Pkt., 5c; oz.; 15c; r/4 lb., 35c; lb., \$1.00.

Klondike.

Davis Perfect-We have omitted cataloguing this variety until we could compare it with other well known sorts and test its merits. We find after a trial of two seasons that it is a desirable variety of extra long white spine strain and recommend it to our customers. Color a dark glossy green. Length ten to twelve inches. Slim in shape and of exceptionally good flavor. One of the very best for forcing under glass and also for out door culture. It is almost seedless one-third the length from the stem and the few seeds it contains are so small and tender they are hardly noticeable when in eating condition. Price, pkt., 5c; oz., 10c; $1 / 4$ lb., 40c; 1 lb., \$1.25.
Extra Long or Evergreen White Spine-Beautiful in shape and color; fruit long and cylindrical, dark green; flesh white, crisp and tender; finest quality. Pkt., 5c; oz., 15c; I/4 lb., 35c; lb., $\$ 1.00$, prepaid.

We offer the following: Pkt.

Chicago Pickling $\ldots \ldots \ldots \ldots . \$ 0.05$

Early Cluster ............. .05

Early Frame ................... .05

Peerless White Spine ....... .05

Green Prolific .............. .05

Gherkin $\ldots \ldots \ldots \ldots \ldots \ldots \ldots \ldots \ldots \ldots \ldots . .05$

\begin{tabular}{rrr} 
oz. & I/4 lb. & \multicolumn{1}{c}{ lb. } \\
$\$ 0.10$ & $\$ 0.35$ & $\$ 1.00$ \\
.10 & .35 & 1.00 \\
.10 & .35 & 1.00 \\
.10 & .35 & 1.00 \\
.10 & .35 & 1.00 \\
.20 & .60 & 2.00
\end{tabular}

\section{CELERY}

Culture-Sow in drills and tread the seed firmly in; thin out to an inch apart and keep the ground well worked and free from weeds; shade the young plants for a week or ten days and do not let the soil dry out. In order to secure stocky plants, cut off the tops once or twice before transplanting, which should be done before July, after plants have attained a height of 4 to 6 inches.

\section{Celery for Profit, by Greiner-Paper, postpaid, 25c.}

White Plume-This handsome sort is valued because naturally the stalk and portions of the inner leaves and heart are white; the whiteness does not show, however, until the plants are about one-third grown; it is unsurpassed for all uses and the earliest celery in the market. Pkt., 5c; 0z., 15c; I/4 lb., 40c; 1 lb., $\$ 1.50$, prepaid.

Golden Self-Blanching-Similar to the White Plume in its self-blanching characteristics, but of a deep golden yellow color. Best stock. (Best French Seed.) Pkt., 15c; oz., 50c; r $/ 4$ lb., $\$ 1.75 ; 1 b ., \$ 6.50$. Regular stock, Pkt., $10 \mathrm{c} ; 0 \mathrm{z}$., $35 \mathrm{c} ; \mathrm{I} / 4$ lb., $\$ 1.25 ; 1$ lb., $\$ 4.00$.
Giant Pascal-Grows about two feet high; the stalks are very broad, thick and crisp, and of a rich nutty flavor. The heart is golden yellow, very full and attractive in appearance; it bleaches very easily and quickly. Pkt., 5c; Oz., 15c; I/4 1b., 45c; 1 lb., $\$ 1.60$, prepaid.

Celeriac, or Turnip-Rooted Celery-Sow seed same as Celery. Transplant in rows two feet apart, nine inches in the row. Thorough cultivation is necessary to secure good roots. Earthing up is not necessary. Roots may be cooked or used as salad.

Giant Smooth Prague-A very large and smooth variety, free from side roots, a desirable sort for market, and an excellent keeper. Pkt., 5c; oz., 15c; I/4 1b., 50c.

New York Market or Giant Self Blanching-One of the recent introductions resembling the White Plume. The stalks are much broader and heavier and much superior in quality. This variety is destined to become a favorite with the market gardeners on account of its earliness, size and freedom from stringiness. Blanches to a deep golden yellow. Don't fail to plant this if you are raising for market. Pkt., 10c; $1 / 2$ oz., 20c; Oz., 35c; I/4 1b., 75c; 1 lb., \$2.50. 


\section{SWEET CORN}

\section{Northern Grown}

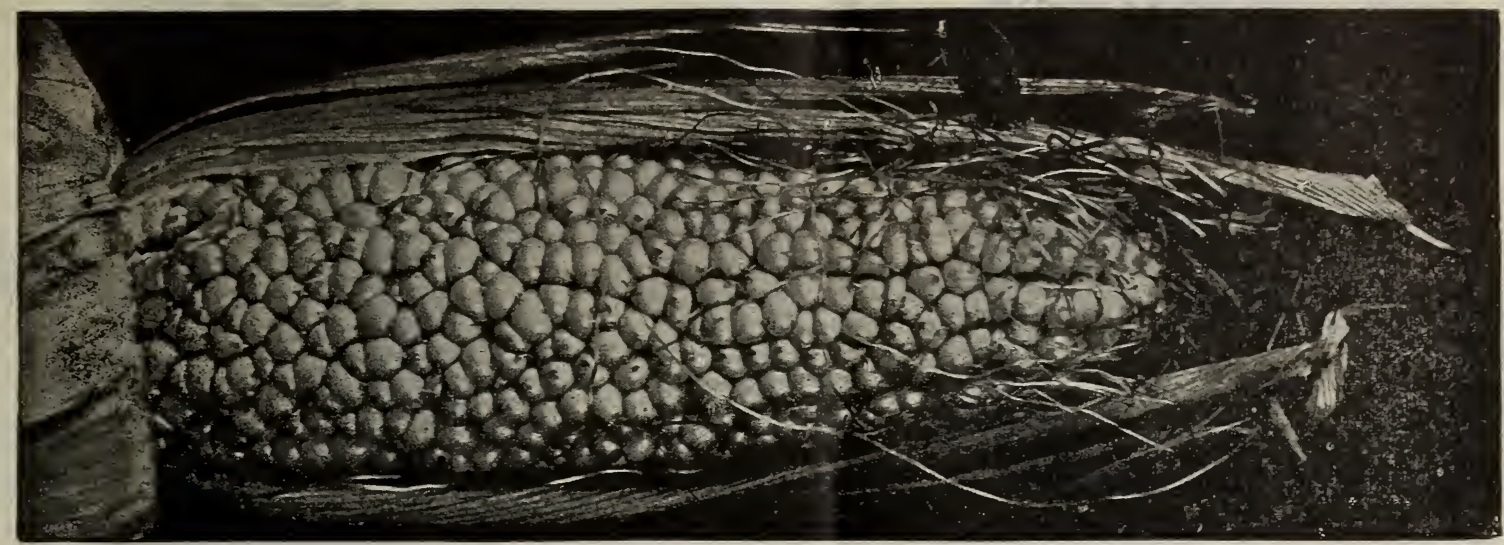

Country Gentleman.

Remember these prices are prepaid on pints and quarts.

If to go with freight or express orders deduct $10 \mathrm{c}$ from pints and $15 \mathrm{c}$ from quart prices on corn.

Country Gentleman-A medium late variety of sweet corn; one of the best for private use; kernels very deep, placed irregularly, but compactly on the cob, the cob itself being very small. Pkt., $10 \mathrm{c}$; pt., 30c; qt., $45 \mathrm{c}$, postpaid; pk., $\$ 1.50$, not prepaid.

White Evergreen-Has most of the characteristics of the regular Stowell's Evergreen. Is about five days earlier; grains pure white and remain tender a long time. A very good variety for canning as it retains the pure white color. Pkt., 10c; pt., 30c; qt., 45c, postpaid; pk., $\$ 1.25$, not prepaid.

Early Evergreen-The best second early sweet corn, possessing every good quality of the Stowell's Evergreen, and resembling it in every respect. Matures ten days earlier than the Evergreen. Pkt., 10c; pt., 30c; qt., $45 \mathrm{c}$, postpaid; pk., $\$ 1.25$, not prepaid.

Stowell's Evergreen-The best late sweet corn in every way, being large eared, hardy and productive, sweet and tender, remaining a long time in condition suitable for cooking; there is no other late sweet corn which can compare with it. Pkt., 10c; pt., 30c; qt., 45c, postpaid; pk., \$1.25, not prepaid.

Extra Early Adams, or Burlington-This is not a true sweet corn, but produces ears well filled with tender white grains. It is very early, and on account of its hardiness and hard, round grain, it can be planted much earlier than sweet corn. Pkt., 10c; pt., 30c; qt., 45c, postpaid; pk., \$1.25, not prepaid.

Early Adams-Same as above, but not as early. Pkt., 10c; pt., 30c; qt., 45c, postpaid; pk., \$1.25, not prepaid. Mammoth White Cory-Ears larger than common Cory, and two or even three to the stalk. Claimed by the originator to be the largest and best extra early sweet corn in existence. The grains are in twelve rows, and the ear is symmetrical and handsome, with no openings between the rows at the base. Grains large and white, of remarkably good quality for such an early sort. Excellent for market. Pkt., $10 \mathrm{c}$; pt., 30c; qt., $45 \mathrm{c}$, postpaid; pk., $\$ 1.25$, not prepaid.

Peep o' Day-One of the sweetest of all the extra early varieties. The stalks grow from $31 / 2$ to $41 / 2$ feet high, and bear 4 to 5 ears to a stalk. Being small stalks stand very close planting. Pkt., 10c; pt., 30c; qt., 55c. By express, not prepaid, pk., \$1.25.
Golden Bantam-Early sweet corn, with yellow kernel; very sweet and delicious, tender and of excellent quality. One of the best early varieties. Pkt., 10c; pt., 30c; qt., 55c. By express, not prepaid, pk., \$1.25.'

Crosby's Early-A most excellent variety and remarkably early; ears of large size, medium length. Pkt., 10c; pt., 30c; qt., 45c; pk., \$1.25, not prepaid.

Early Champion-The earliest large sweet corn grown. This variety is the earliest large sweet corn yet introduced, being only a few days later than the first early small sorts. It is 10 and 12 rowed, and pure white in color; sweet and tender. Pkt., 10c; pt., 30c; qt., 45c, postpaid; pk., \$1.25, not prepaid.

We offer the following standard varieties:

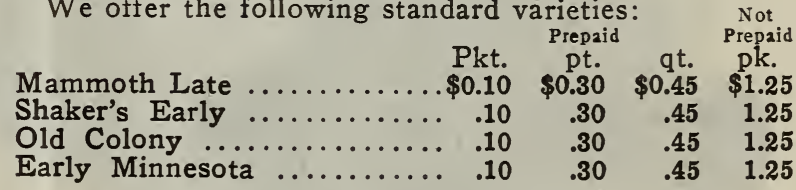

\section{CHICORY}

Culture-Sow in drills half an inch deep, in rich, mellow soil; the after-culture being the same as recommended for carrots.

Large Rooted-Roots of fine form, the chicory of commerce, used to adulterate coffee. Pkt., 5c; oz., 10c; I/4 1b., 25c; 1b., 75c.

\section{KOHL RABI}

Early White Vienna-Best early variety for table; bulbs white. Pkt., 5c; oz., 20c; I/4 1b., 50c.

Early Purple-Similar to the last, except in color. Pkt., 5c; Oz., 20c; I/4 lb., 50c.

\section{HARNDEN'S BLUE GRASS MIXTURE}

To make a solid velvety turf, use our Extra Mixture for Lawns. Prices as follows: One pound, 35 c; 3 pounds, $\$ 1.00$; bushel $\$ 4.25$. If to go by mail add onehalf cent per ounce. 


\section{ENDIVE}

Culture-For early use sow in April. For the main crop sow in June and July, and when up an inch or two, transplant to one foot apart each way.

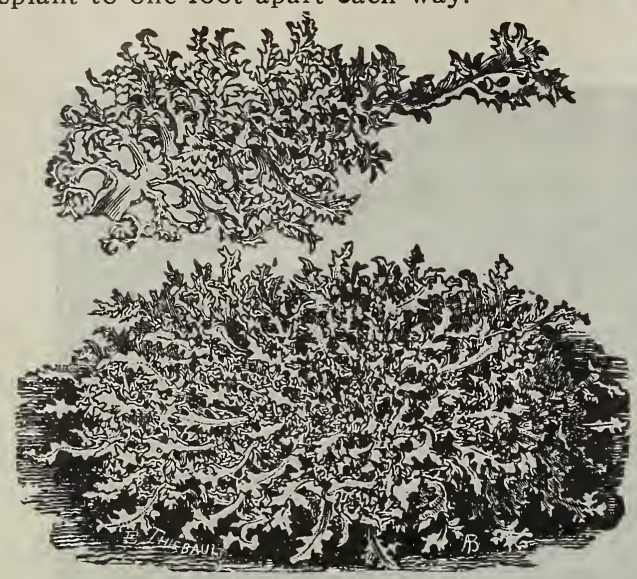

Endive-Green Curled.

Green Curled-Very hardy, with dark green curled leaves; tender and crisp. Pkt., 5c; oz., 15c; $1 / 4$ 1b., 40c; lb., \$1.25, prepaid.

Moss Curled-Handsomely curled; fine quality; a desirable sort. Pkt., 5c; oz., $15 \mathrm{c}$; $1 / 4$ lb., $40 \mathrm{c}$; lb., $\$ 1.25$, prepaid.

Broad Leaved Batavian-Large heads of broad, thick leaves; if bleached, the inner leaves make a fine salad. Pkt., 5c; 0z., 15c; $1 / 4$ lb., 40c; 1b., $\$ 1.25$, prepaid.

\section{KALE OR BORECOLE}

Culture-Cultivate the same as cabbage. For summer and fall use, sow in April and transplant in June; for early spring greens, sow in September. Two pounds per acre in drills, three pounds broadcast.

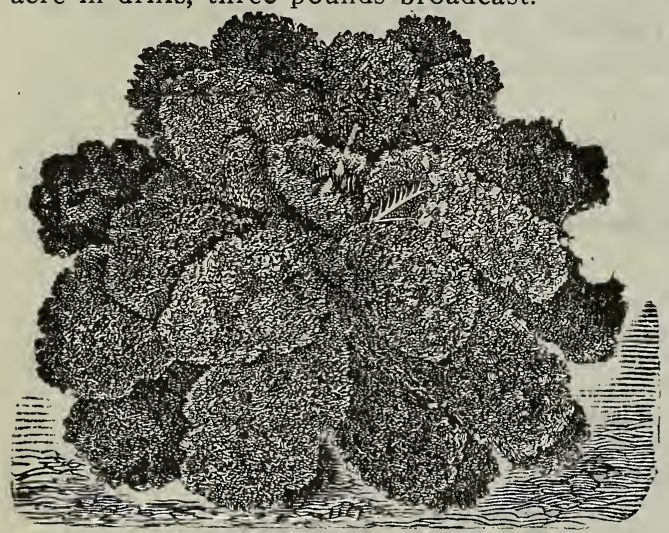

Kale-Dwarf Green Curled German.

Dwarf Green Curled German-Very hardy, the main sort planted by gardeners. Pkt., 5c; oz., 10c; $1 / 4 \mathrm{lb}$, 25c; 1b., 75c, prepaid.

Dwarf Green Curled Scotch-Leaves of a bright green; very tender and closely curled; rarely exceeding 18 inches in height, but spreading out, under good cultivation, to 3 feet in diameter. Pkt., $5 \mathrm{c} ; 0 z ., 10 \mathrm{c} ; 1 / 4 \mathrm{lb}$., $25 \mathrm{c}$; $1 \mathrm{~b}$., $75 \mathrm{c}$, prepaid.

Tall Green Scotch-Finely curled; even more tender after being touched by frost. Pkt., $5 \mathrm{c}$; oz., 10c; $1 / 4 \mathrm{lb}$., 25 c; 1 b., $75 \mathrm{c}$, prepaid.

Siberian-Dwarf growth; bluish green leaves; extensively grown as winter greens. . Per pkt., 5c; oz., 10c; $1 / 4$ lb., 20c; 1 lb., $75 \mathrm{c}$.

\section{EGG PLANT}

Culture-Sow in March or April in a hot-bed; transplant when two inches high into a second hot-bed, or let them remain and thin out to four inches apart. Uniform heat is essential to this plant, and it rarely recovers from the least chill in its early growth. When the weather becomes settled, transplant into the open ground, two and one-half feet apart each way. One ounce to 1,500 plants.

New York Improved (the only variety to plant) - The best in cultivation; 1 a rg e, round, dark purple, and very productive. Pkt., 10c; oz., 35c; lb., $\$ 1.25$, prepaid.

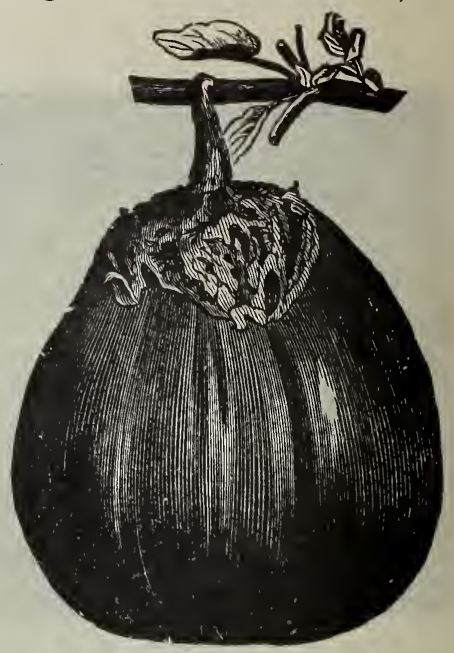

New York Improved

\section{LEEK}

One Ounce Will Sow 100 Feet of Drill-Leek is reported more delicate than the onion for soup, etc. Sow in seed-bed middle of spring, when the plants are three or four inches high, transplant them into rows wide enough apart to admit the hoe between them. With good culture they may be grown five or six inches in circumference.

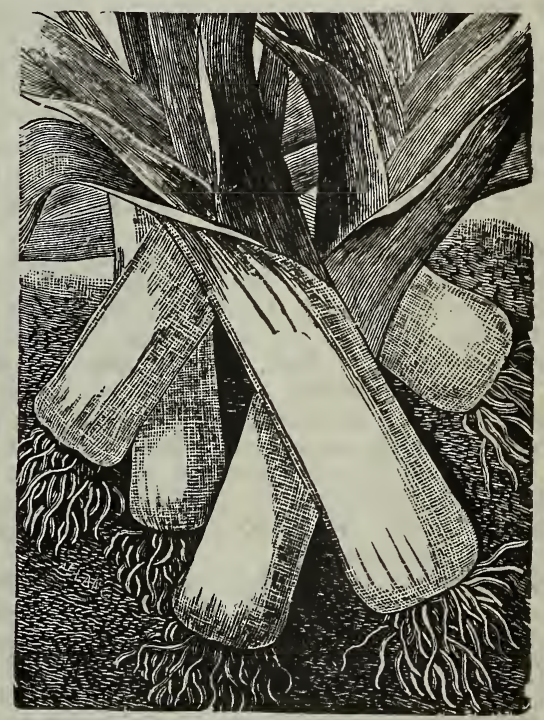

Leek Giant Carentan.

American Broad Leaf-This variety is more largely used in this country than any other; plant strong, with broad leaves. Pkt., 5c; oz., 15c; I/4 lb., 35c; 1b., $\$ 1.25$, prepaid.

Giant Carentan-Grows to immense size, broad leaves; one of the best; hardy. Pkt., $5 c$; oz., 15c; $1 / 41 \mathrm{lb}$,
35c; lb., $\$ 1.25$, prepaid. 


\section{LETTUCE}

Culture-For general crop, sow as early in the spring as the ground can be worked, in drills 18 inches apart, and thin the young plants to 4 inches apart in the row. As the plants begin to crowd, thin them out and use as equired. Keep the soil constantly loose by frequent hoeing.

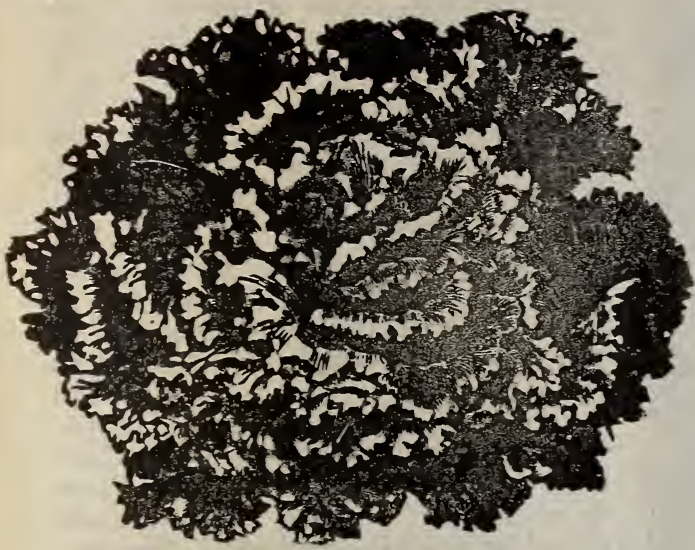

Grand Rapids Forcing.

May King-The plants of this new lettuce are all quick growth. It is an extra fine heading lettuce and very early. Can be sown for spring and fall in the open round. Can also be grown in cold frames during the winter months. Practically all of the plants head, and ire extremely handsome in appearance, and grow to a liameter of 6 or 7 . inches. Has broad green outer eaves, folding closely about the round solid head. In :ool weather the edges of the outer leaves are slightly inged with brown, the inner leaves blanch to a rich yolden yellow. 'Price, per pkt., 5c; oz., 10c; I/4 lb., 30c; lb., $\$ 1.00$

California Cream Butter-This is one of the best of he summer varieties of head lettuce; a strong growing ;ort, with large green leaves, marked with scattered rown dashes; sometimes called Winter Lettuce. Pkt., ic; Oz., 10c; $1 / 4$ lb., 25c; lb., 80c, prepaid.

Denver Market-An early variety of head lettuce, ither for forcing or open ground; forms large heads if a desirable light color. The leaves are beautifully narked and blistered like Savoy cabbage and are very :risp and tender. Pkt., 5c; oz., 10c; 1/4 lb., 30c; 1 lb., 1.00, prepaid.

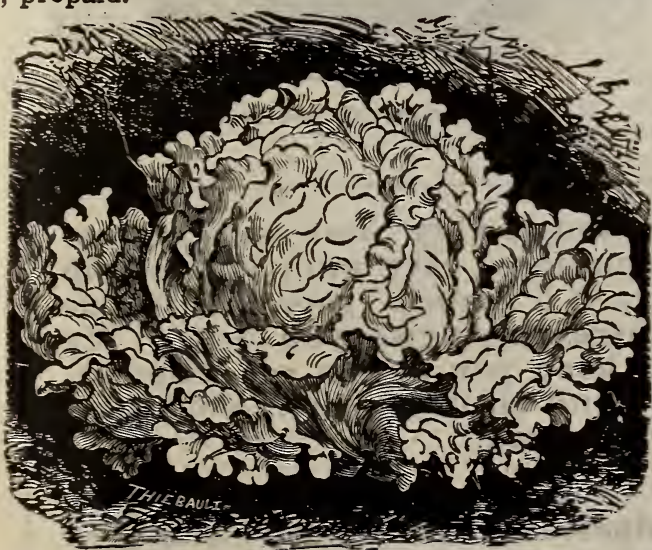

California Cream Butter.
Kansas City, or Golden Forcing-A very popular variety, originated on our market in Kansas City. Used largely by our market gardeners, either for open ground or forcing; light in color; sometimes called Golden Forcing, and resembles the Denver Market, but not quite as near a head variety. This is used largely for forcing. Price, per oz., $15 \mathrm{c}$; $1 / 4$ lb., $40 \mathrm{c} ; 1 \mathrm{lb}$., $\$ 1.25$, prepaid.

Iceberg-An extremely hard head variety. Good for home and market. Pkt., 5c; oz., 10c; $1 / 4$ lb., 30c; 1 lb., $\$ 1.00$.

\section{Curled or Loose Head Varieties}

Black Seeded Simpson-A standard variety for forcing and early out-door culture. It forms large, loose clusters of leaves of light yellowish green color; the leaves are large, thin, very tender, slightly ruffled and blistered, the inner ones nicely blanched, and even the large outside leaves are tender and of good quality. Pkt., 5c; oz., 10c; I/4 lb., 25c; 1b., 80c, prepaid.

Grand Rapids Forcing-A forcing variety especially adapted for greenhouse culture in the winter, for which it has no peer. A strong grower, very tender, and will keep from wilting longer while exposed for sale than any other sort. Pkt., 5c; oz., 10c; $1 / 4$ lb., 30c; 1 lb., $\$ 1.00$, prepaid.

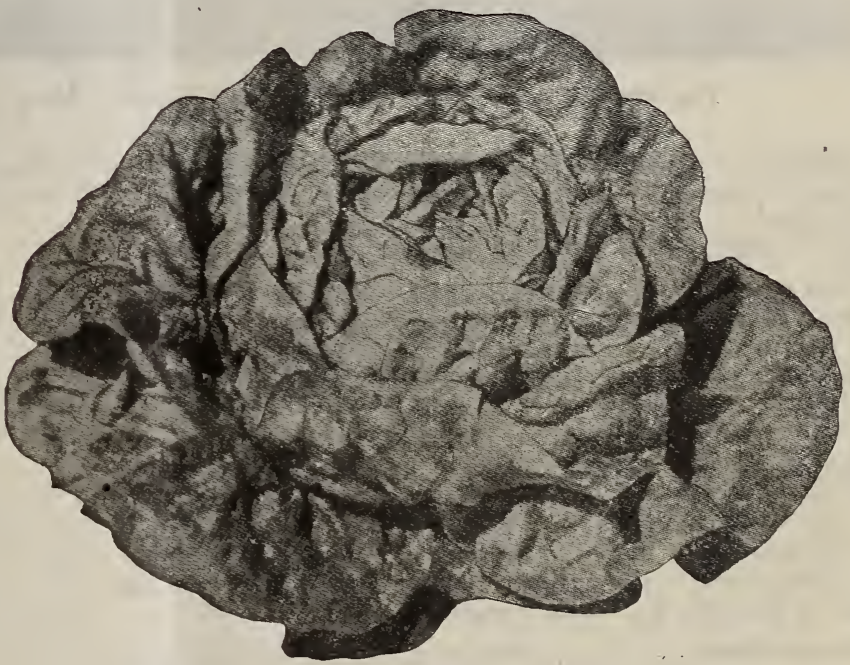

May King Lettuce.

Cos Lettuce-The Cos Lettuce is distinct from the preceding sorts, having long, narrow, spoon-shaped leaves, which usually fold into loose sugar-loaf shaped heads, which blanch better by having the outer leaves drawn about them and tied. On account of their exceeding crispness, tenderness and delicate flavor, they are becoming more and more popular in this country. Leaves yellowish white in color, long, narrow, upright, folding into a solid head like that of an Early York Cabbage; crisp and tender; self-blanching." Plkt., 5c; oz., $15 \mathrm{c}$; $1 / 4$ lb., $35 \mathrm{c}$; $1 \mathrm{~b}$., $\$ 1.25$, prepaid.

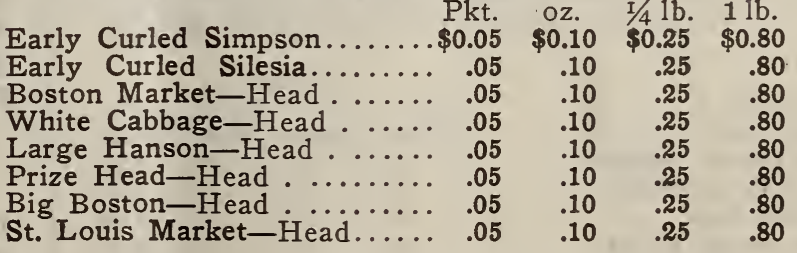




\section{MUSK MELON}

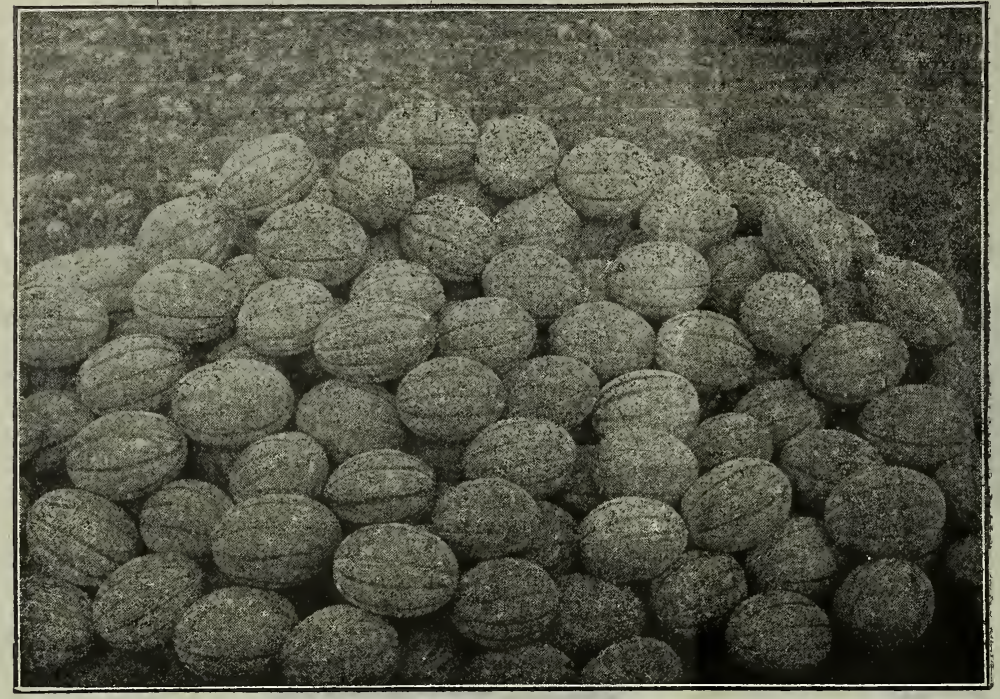

Culture-Melons thrive best in light, dry, sandy. soil; plant in hills 6 feet apart each way, 12 seeds in each hill; remove 2 to 3 inches of soil where the hill is desired, and fill in with wellrotted manure, then replace the soil 4 inches high, raking the hill rather flat. When the plants have made the second pair of leaves, thin out to 4 in a hill. If the plants grow very rank pinch off the ends when about 3 feet long.

Burrell's Gem-Six to seven inches in length and four to four and a half in diameter. Well ribbed and covered with a fine grayish netting. Skin a rich dark green with deep orange salmon colored flesh of the finest flavor, sweet and tender. The flesh is thick and firm and ripens close to the skin. One of the most popular varieties for hotels and restaurants ever introduced. Per pkt., 5c; oz., 10c; $1 / 4$ lb., 35c; 1 lb., \$1.25.

The New Rocky Ford Melon With Golden Meat.

Champion Market-The melons are almost a perfect globe in shape, and densely netted, weighing from 4 to 5 lbs. each; flesh light green in color; of a rich, sweet flavor. Pkt., 5c; oz., 10c; $1 / 4$ lb., 35c; lb., $\$ 1.25$, prepaid.

Chicago Market-This deservedly popular variety has been steadily growing in favor and holds its own against all melons in the market. Nearly round, flattened at ends and deeply and regularly ribbed, skin green, densely netted; flesh light green. Pkt., 5c; oz., 10c; $1 / 4$ lb., $35 \mathrm{c}$; 1b., \$1.25, prepaid.

Extra Early Hackensack-A variety possessing all the good qualities of the well-known Hackensack, but at least ten days or two weeks earlier. The melons weigh from 4 to $10 \mathrm{lbs}$. each, are of nutmeg shape, heavily netted and have a light green flesh. Pkt., 5c; oz., $10 c$; $1 / 4$ lb., 35c; lb., $\$ 1.25$, prepaid.

Rocky Ford-Oblong, somewhat similar to the Netted Gem. Grow very uniform in shape and size, weighing from $11 / 2$ to $2 \mathrm{lbs}$; skin green and thickly netted; flesh of a light green color and very sweet. The most popular shipping variety grown. Pkt., $5 \mathrm{c}$; oz., 10c; 1/4 lb., $35 \mathrm{c} ; 1 \mathrm{~b} ., \$ 1.25$, prepaid.

Paul Rose or Petoskey-Flesh firm; a rich orange red color, like that of the Osage, but sweeter and more highly flavored. One of the best sorts for home garden. Pkt., 5c; oz., 10c; 1/4 lb., 35c; 1b., $\$ 1.25$, prepaid.

Banana-An entirely distinct variety, bearing long, slender banana-like fruit. Skin creamy white and entirely free from netting. Flesh deep salmon color, thick and of good quality. Pkt., 5c; 0z., 15c; 1/4 lb., 50c; lb., $\$ 1.50$.

Standard Sorts. Postpaid. Jenny Lind Sorts.

Early Green Nutmeg......... .05

Netted Gem Round.......... . 05

Emerald Gem . .............. .05

Baltimore or Acme.......... .05

Montreal Market .......... .05

Netted Gem Oblong ......... 05

Large Green Nutmeg........ .05

oz. $\quad 1 / 4 \mathrm{lb}$

$\$ 0.10 \$ 0.30 \quad \$ 1.00$

$\begin{array}{lll}.10 & .30 & 1.00\end{array}$

$\begin{array}{lll}.10 & .30 & 1.00\end{array}$

$\begin{array}{lll}.10 & .30 & 1.00\end{array}$

$\begin{array}{lll}.10 & .30 & 1.00\end{array}$

$\begin{array}{lll}.10 & .30 & 1.00\end{array}$

$\begin{array}{lll}.10 & .30 & 1.00\end{array}$

$\begin{array}{lll}.10 & .30 & 1.00\end{array}$

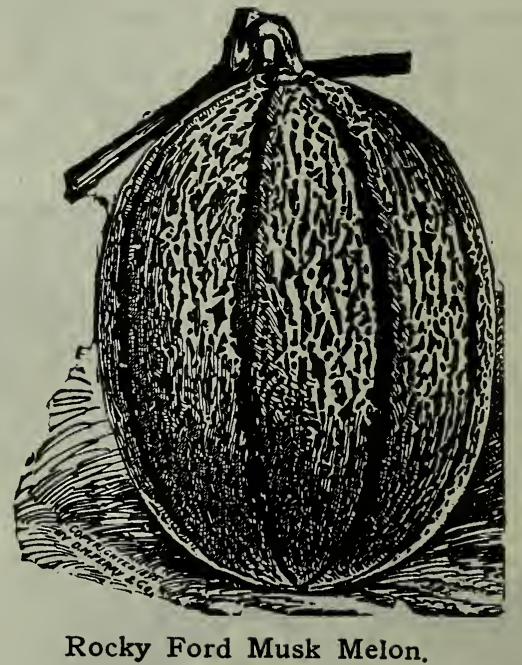

The Kansas City Seedsman-a paper with a purpose. We want you to help us make it a farmers' paper. Write us any interesting news you have. We aim to keep you posted on prices together with all information obtainable regarding seeds.

Business is good. We have branched out, and you can get Harnden's seeds at our up-town store, 1418 Grand Ave., and 505 Walnut Street, Kansas City. 


\section{WATERMELON}

If ordered to go by express or freight at purchaser's expense, deduct $8 \mathrm{c}$ per pound.

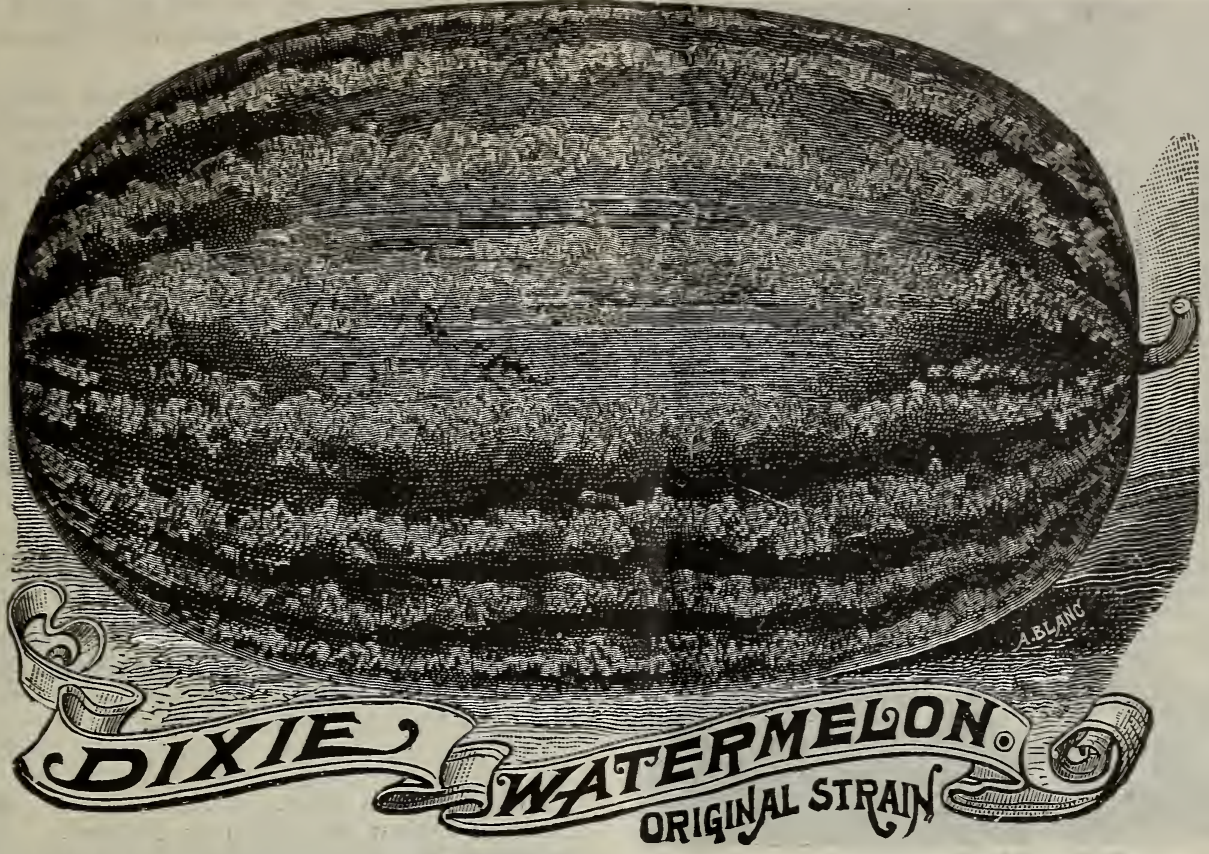

Blue Gem or Iceberg-In shape and appearance it is similar to Kolb's Gem. The melons are uniformly large and of a thick oval form; color, dark green, with faint stripes of lighter shade, but much darker than Kolb's Gem. Flesh, deep pink. It is an excellent shipper; large and solid. Flesh crisp and entirely free from stringiness. Seeds black. Pkt., 5c; oz., 10c; I/4 1b., 20c; $1 \mathrm{lb}$., 60c, prepaid; 5 lbs., $\$ 2.50$, not prepaid.

Triumph-As a market sort and for shipping the best ever produced. A cross between the Duke Jones and the Kolb's Gem; has the handsome appearance of the former and the firm shipping qualities of the latter. The rind is of dark green color, with indistinct stripes of a little lighter color. The average size, large. Pkt., 5c; Oz., $10 \mathrm{c} ; \mathrm{I} / 4$ lb., $20 \mathrm{c}$; lb., 50c, prepaid; $5 \mathrm{lbs}$., $\$ 2.00$, not prepaid.

The Dixie-A cross between the Kolb's Gem and the Mountain Sweet; far superior to the former; larger, earlier and much more productive. Pkt., $5 \mathrm{c} ; \mathrm{oz} ., 10 \mathrm{c} ; \mathrm{I} / 4$ lb., 20c; 1 lb., 50c, prepaid; 5 lbs., $\$ 2.00$, not prepaid.

Kolb's Gem-Attains a weight of from 25 to 50 pounds; flesh bright red, solid, sweet and luscious; fruit round or slightly oval, marked with irregularly mottled stripes of dark and very light green. Plkt., 5c; oz., 10c; I/4 lb., 20c; lb., 60c, postpaid; 5 lbs., \$2.50, not prepaid.

Sweet Heart-Fruit large, oval, uniformly mottled, light and dark green; rind thin, but firm; flesh red, solid, melting and sweet. Pkt., 5c; oz., 10c; I/4 lb., 20c; lb., 60c, prepaid; 5 lbs., $\$ 2.50$, not prepaid.

Alabama Sweet-One of the earliest melons for market purposes; long, dark in color; meat, rich crimson, delicious flavor. It is used largely in the South. The seeds are light. Plkt., 5c; oz., 10c; I/4 1b., 25c; 1b., 75c, prepaid.

Georgia Rattlesnake, or Gypsy-Standard Southern variety of large size, possessing very remarkable shipping qualities; oblong, square at the ends; scarlet flesh. Pkt., 5c; oz., 10c; I/4 1b., 20c; lb., 60c, prepaid; 5 lbs., $\$ 2.50$, not prepaid.
McIver's Wonderful Sugar-The sweetest melon grown; attains a great weight; has handsome appearance; never cracks or loses its fine flavor in the wettest season. Pkt., 5c; oz., 10c; I/4 lb., 20c; 1b., 60c; 5 lbs., $\$ 2.50$, not prepaid.

Kleckley's Sweet-Large, oblong melon; skin dark green; flesh bright scarlet, very sweet and sugary; one of the best melons that has been offered. If you have a home garden you can't afford to be without this. Pkt. 5c; oz., 10c; I/4 lb., 25c; lb., 75c; 5 lbs., $\$ 3.00$, not prepaid.

Black Diamond-A cross between Kolb's Gem and Hoosier King; one of the most prolific watermelons ever planted; color rich, dark green, almost black; symmetrical in shape, roundish to blunty oval; uniform throughout the field; in size they are very large. Plst. 5c; oz., 10c; I/4 lb., 20c; 1 lb., 60c, prepaid; 5 lbs., $\$ 2.50$, not prepaid.

Light Icing, or Gray Monarch-Mottled gray skin, long shape, flesh crimson, sweet, delicious flavor. Pkt. $5 c$; oz., 10c; I/4 lb., 20c; lb., 60c; 5 lbs., \$2.50, not prepaid.

Halbert Honey-Dark rich colored skin, regular in shape, crimson meat, small white seed-a very fine melon for home use; fully equals Kleckley's Sweet. Pkt. 5c; oz., 10c; I/4 lb., 25c; 1 lb., 75 c; 5 lbs., $\$ 3.00$, not prepaid.

Cole's Early-This is an extra early melon of oval form, small in size, handsomely striped with light and dark green, of good quality. Desirabe for home use. Plkt., 5c; oz., 10c; I/4 lb., 20c; lb., 60c, postpaid; 5 lbs., $\$ 2.50$, not prepaid.

Standard Sorts. Seminole. Pkt.

Florida Favorite. $\$ 0.05$

05

Phinney's Early. .......... .05

Pride of Georgia............. .05

Mountain Sweet................ 05

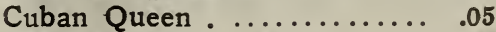

Peerless or Ice Cream....... .05

George Queen ...........................

Black Diamond .............. .05

Prepaid

oz. $\quad \mathrm{I} / 4 \mathrm{lb} \quad 1 \mathrm{lb}$ $\$ 0.10 \quad \$ 0.20 \quad \$ 0.50$ 


\section{SURE-CROP MUSHROOM SPAWN}

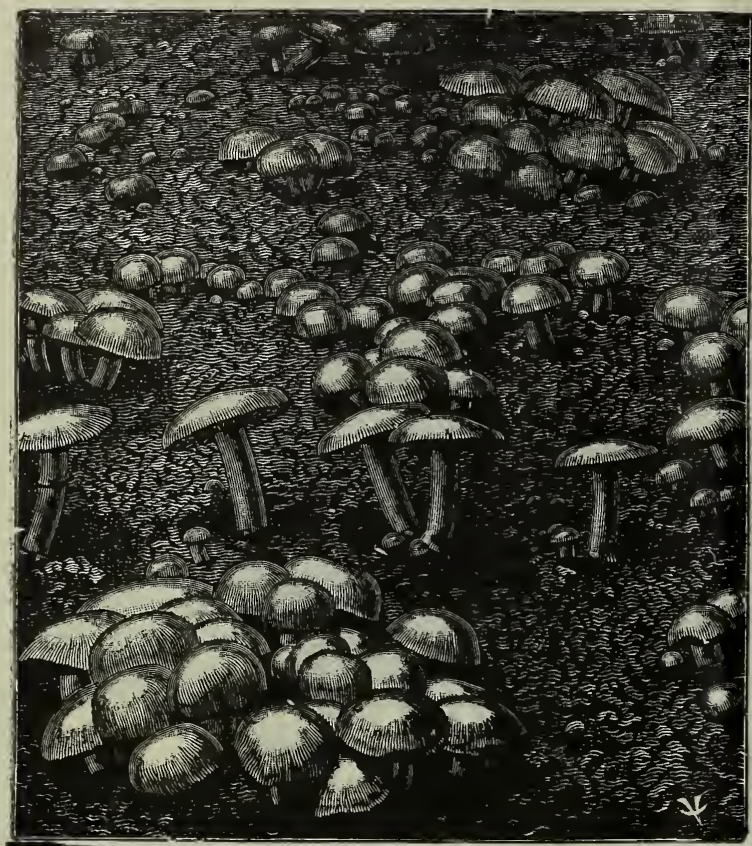

A Bed of Mushrooms.

Culture-Any dark room or pit where the temperature can be kept from 50 to 60 degrees will do for the culture of mushrooms. In preparation for a mushroom bed, procure soil from an old pasture, and fresh horse manure, free from straw or litter, and mix thoroughly in proportion of three parts horse manure to one of loam; previous to mixing, the manure should be turned a number of times to get rid of the heat; make out of this compost a bed 8 to 10 inches deep, pressed solidly; let the temperature recede until it reaches about 90 degrees, then plant pieces of spawn the size of a walnut in holes 2 to 3 inches deep, and 6 inches apart each way; cover the holes, pressing the dirt solid. At the expiration of ten days cover the whole with 2 inches of fresh loam and over this spread 3 or 4 inches of straw, hay or litter; in about eight weeks the mushrooms make their appearance. If the surface becomes dry, wet with warm water. One brick of spawn will plant 8 or 9 square feet.

English Spawn-1 brick, 20c; prepaid, 30c; 5 lbs., $\$ 1.25 ; 10 \mathrm{lbs}$., $\$ 1.75$, not prepaid.

French Spawn-Our own importation. In original boxes of $2 \mathrm{lbs}$. at $\$ 1.00$ per box, not prepaid. Pamphlet on Mushroom Culture packed in each box.

Robinson's Mushroom Culture-A book bound in cloth, giving directions how to prepare mushroom beds and raise mushrooms. Postpaid, 60c.

\section{MUSTARD}

Southern Giant Curled-Highly esteemed in the South, where the seed is sown in the fall and used in the spring as salad. Our stock is the true curled leaf, with dark green leaves, edges of which are finely curled. Pkt., 5c; 0z., 10c; 1/4 lb., 25c; 1 lb., 75c, prepaid.

Brown or Black-The common small-seeded variety; more pungent than the White. Pkt., 5c; 0z., 10c; $1 / 4$ lb., $15 \mathrm{c}$; $1 \mathrm{~b} ., 35 \mathrm{c}$, prepaid.

White-Best for culinary purposes and for salads. Pkt., 5c; oz., 10c; 1/4 1b., 15c; 1 lb., 35c, prepaid.

\section{OKRA or GUMBO}

Culture-This vegetable is extensively grown in the Southern states, where its long pods, when young, are used in soups or stews, and are served like asparagus. In hills or drills 3 feet apart and trim out to 3 plants in a hill.

Improved Perkins Giant Green Pod-A new Okra esteemed by canners and market gardeners. It is a great improvement on the old green podded sorts. Large, handsome green pods; fine quality; very productive; 4 to 5 feet tall. Pkt., $5 \mathrm{c}$; oz., $10 \mathrm{c} ; \mathrm{r} / 4 \mathrm{lb}$., $20 \mathrm{c}$; 1b., 50c, prepaid.

White Velvet-The pods of this variety are not ridged or square edged, but are round and smooth, and much larger than the other sort. Pkt., 5c; oz., 10c; $1 / 4$ lb., 20c; 1b., 60c, prepaid.

Dwarf Green-Plants of dwarf, stocky growth, wonderfully prolific and mature pods ready for use ten days to two weeks earlier than the tall varieties; pods 3 to 4 inches in length, and heavily ridged. Pkt., 5c; oz., 10c; I/4 lb., 20c; 1b., 50c, prepaid.

\section{ONION SETS}

Write for special prices on large lots. Prices variable. Top sets, 28 lbs., per bushel; bottom sets, $32 \mathrm{lbs}$., per bushel.

Prepaid Not Prepaid

Qt. Peck

Top or Button Sets $\ldots \ldots \ldots \ldots \ldots \ldots \$ 0.30 \quad \$ 1.00$

Bottom Onion Sets, Red or Yellow.... $\quad .30 \quad \mathbf{7 5}$

Bottom Onion Sets, White............ $\quad .30 \quad 1.00$

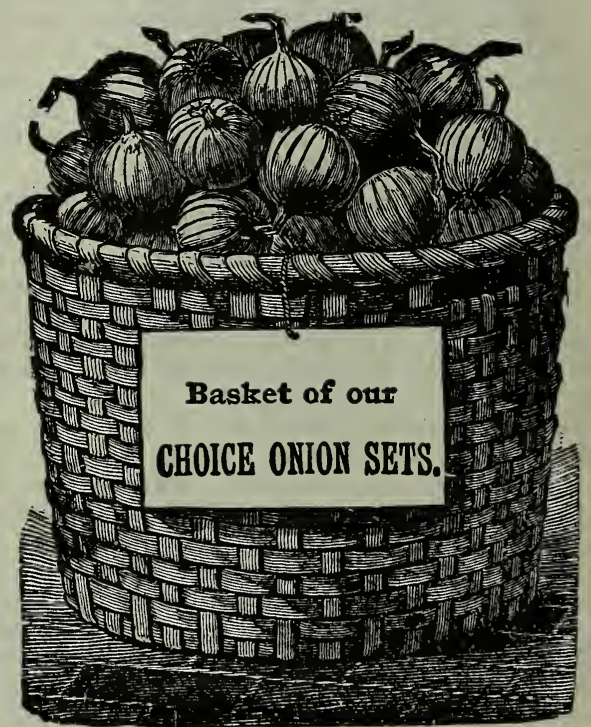

Your order by mail is handled three times. We enter it, pack and ship the same day unless you want us to delay shipment for some reason. Prompt attention to business brings more customers. If your order reaches you promptly, tell your friends; if not, tell us. 


\section{ONION}

\section{A Strictly High-Grade Strain of Seed}

If in want of larger quantities for sowing sets or more than pound lots, write us and we will make you our very best price.

Culture-Full size onions may be grown from the seed fully as well, much more cheaply and only little later than from sets. For this purpose from 4 to 5 pounds of seed per acre are required. Sow the seed thinly one-half inch deep in drills one foot apart, and thin out later, leaving about 8 plants to the foot. The first hoeing should be given, just skimming the ground between the rows, as soon as they can be seen the length of the row, but do not ridge up to the growing bulbs.

Extra Early Red-The earliest of all red onions. Flat in shape. Pkt., 5c; oz., $15 c$; $1 / 4$ lb., 50c; 1b., $\$ 1.60$, prepaid.

Large Red Wethersfield-The standard variety so largely used for commercial purposes, good size, an immense yielder; deep red color; fine keeper. Pkt., 5c; oz., 15c; I/4 lb., 50c; lb., \$1.60, prepaid.

Extra Early White Pearl-A pure silvery-white onion of very quick growth, frequently maturing in seventy days from sowing the seed. Bulbs are flattened, of medium size, with silvery-white skin; flesh crisp and mild in flavor. Pkt., 5c; oz., 20c; $1 / 4 \mathrm{lb}$., 60c; 1b., $\$ 2.00$, prepaid.

Yellow Strasburg or Dutch-Bulbs quite flat, of good size; skin rich yellow, turning to brown when exposed; ripens early; flesh white and of mild flavor; keeps well. It is one of the very best to grow for sets. Pkt., 5c; oz., 10c; $1 / 4$ lb., $40 c$; lb., $\$ 1.35$, prepaid.

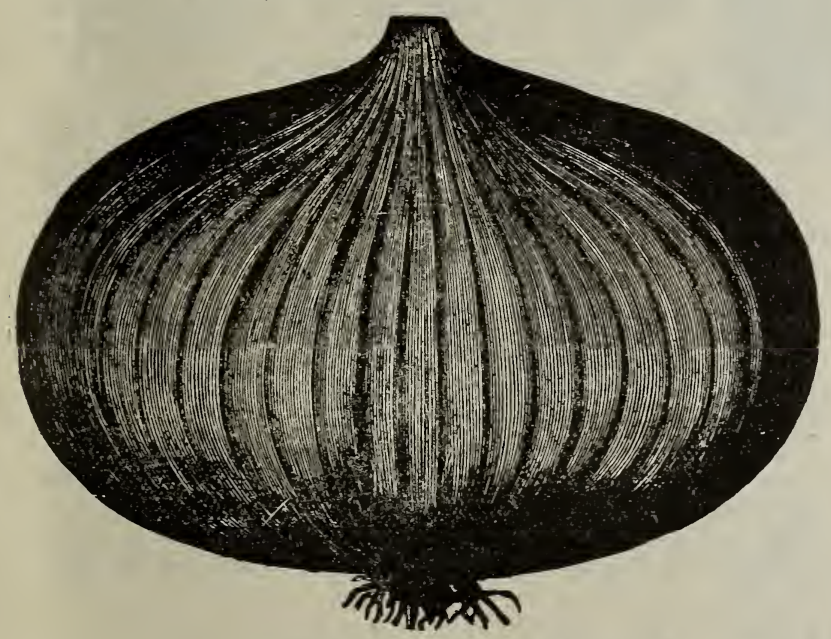

Large Red Wethersfield.

Mammoth Silver King-An Italian variety of special merit; remarkably early, of large size and fine quality. A popular variety in the South, where it grows to an enormous size; white flesh; shape flat; mild and delicate flavor. Plkt., 5c; 0z., 20c; 1/4 1b., 60c; 1b., \$1.75, prepaid.

Flat Yellow Danvers-Like the Globe Yellow Danvers, but rather more flattened. One of the best keeping onions grown; flesh white, fine grained, firm and mild; perfect in shape and a large cropper. Pkt, 5c; oz., 15c; $1 / 4$ lb., 40c; lb., $\$ 1.35$, prepaid.

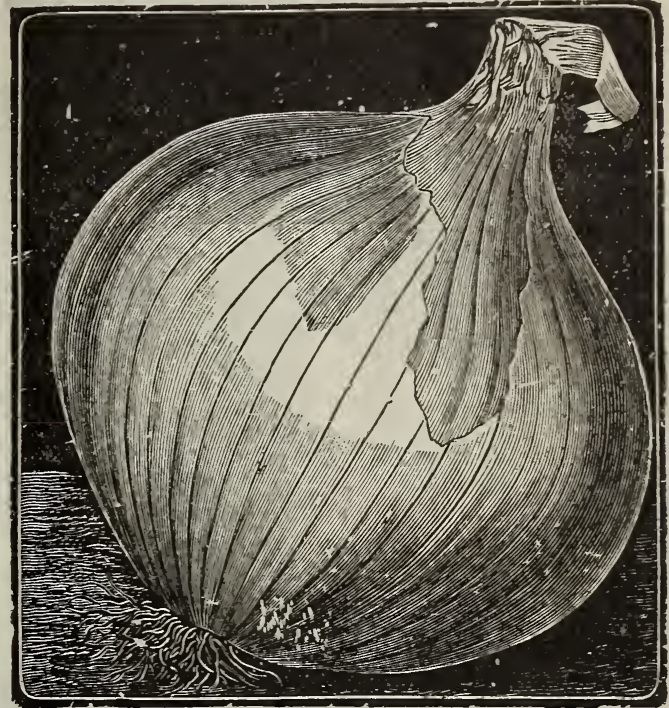

Southport Yellow Globe.

White Portugal or Silverskin-An early flat white variety; mild flavor; excellent for growing sets; one of the best for pickling. Pkt., 5c; oz., 20c; $1 / 4$ lb., 60c; 1b., $\$ 2.00$, prepaid.

White Bermuda-This is the onion that has been recommended so highly for Southern growers. Grows to an immense size; the skin is very thin, white and fine-grained; of mild and pleasant flavor. Our seed of this splendid variety is Teneriffe grown and absolutely pure. Pkt., 5c; 0z., 20c; $1 / 4$ lb., 60c; lb., $\$ 2.00$, prepaid.

Australian Brown-Of medium size, wonderfully hard and solid and of somewhat globular form; the color of the skin is a clear amber-brown. It is very early in ripening and never makes any stiff necks or scallions. It has the reputation of keeping indefinitely; will keep longer in good condition than any other onion known. Pkt., 5c; oz., 10c; $1 / 4$ lb., $40 \mathrm{c}$; 1 lb., $\$ 1.35$, prepaid.

Southport Yellow Globe-A favorite variety in the East, where it is grown almost to the exclusion of al other sorts; bright yellow in color; a perfect keeper and a heavy yielder. Pkt., 5c; 0z., 15c; 1/4 1b., 50c; 1b., $\$ 1.50$ prepaid.

Southport Red Globe-Similar to the White Globe except in color; they are perfectly globe-shaped, more so than the Globe Danvers; of handsome appearance and heavy croppers; excellent keepers; a very desirable sort. Plkt., 5c; oz., 15c; $1 / 4$ lb., 50c; lb., $\$ 1.50$, prepaid.

Southport White Globe-One of the handsomest onions grown and rapidly taking the lead in our market; a large yielder, mild in flavor, clear white skin and in every way to be recommended; one of the best varieties to sow for early bunching. Pkt., $5 \mathrm{c}$; 0z., $25 \mathrm{c}$; $1 / 4 \mathrm{lb}$. $75 \mathrm{c} ; 1 \mathrm{~b} ., \$ 2.50$, prepaid.

Prize Taker, or Spanish King-Like nearly all Spanish onions, this makes extra large size onions and of particularly fine flavor. The outside skin is a rich yellow straw color, and the flesh is pure white, sweet, mild and tender. Ripens up fine and hard, and makes a very handsome and attractive onion. Pkt., $5 c ; 0 z ., 20 c ; 1 / 4$ 1b., 60c; 1b., \$1.75. 


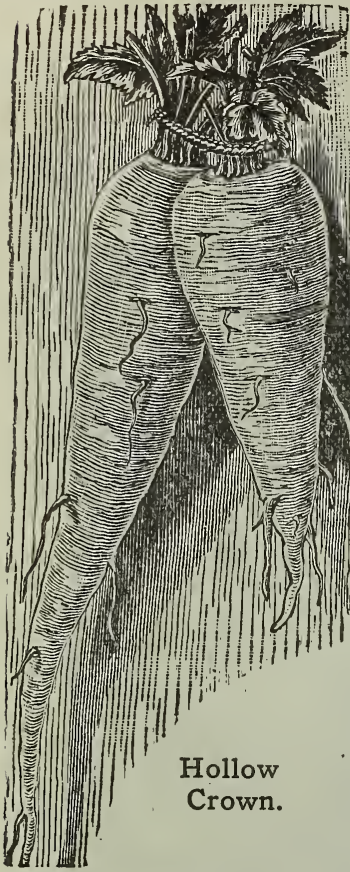

\section{PARSNIP}

Culture - The parsin thrives best in a deep, mellow soil. Sow the seed early in the spring in rows fifteen inches apart, covering the seed half an inch deep; thin out the plants, when well up, to five inches apart in the rows.

Hollow Crown-Smooth, large roots, sweet and of most excellent flavor. Pkt. 5c; 0z., 10c; I/4 1b., 20c; 1b., $50 \mathrm{c}$, prepaid.

Improved Guernsey-Not so long as the Hollow Crown, but of greater diameter. Pkt., 5c; oz., 10c; I/4 lb., 20c; 1b., 50c, prepaid.

\section{PARSLEY}

Culture-The seed is very slow to germinate, and should be sown early in the spring. previously soaking the seed for a few hours in warm water. Sow in drills one foot apart, and when the plants are well up, thin to one foot in the row. When the plants are about three inches high cut of all the leaves; the plant will be brighter and better curled; every cutting will result in improvement. One ounce to 150 feet of drill.

Champion Moss Curled-Leaves beautifully curled and mossy. Pkt., 5c; oz., 10c; I/4 1b., 25c; lb., 75c, prepaid.

Double Curled-A fine variety; excellent for garnishing. Pkt., 5c; oz., 10c; I/4 1b., 25c; lb., 75c, prepaid.

Hamburg or Turnip Rooted-Sometimes called German Parsley; a fleshy rooted variety. Pkt., 5c; oz., 10c; $\mathrm{I} / 4$ lb., 25c; lb., 75c, prepaid.

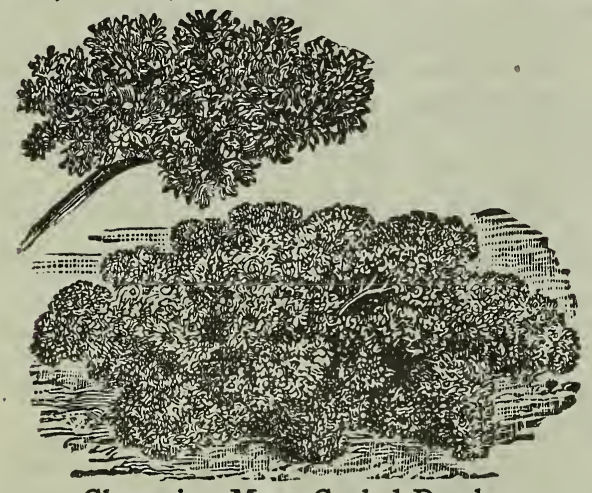

Champion Moss Curled Parsley.

\section{PEPPER}

Improved Bull Nose or Sweet Mountain-A very large sort of inverted bell-shape, suitable for filling or for a mixed pickle; flesh thick, hard and less pungent than most other sorts. Pkt., 5c; oz., 25c; 1/4 1b., 60c, prepaid.

Long Red Cayenne-Pods small, cone-shaped, scarlet red, and when ripe used for pickles and pepper sauce. Pkt., 5c; oz., 25c; I/4 1b., 75c, prepaid.

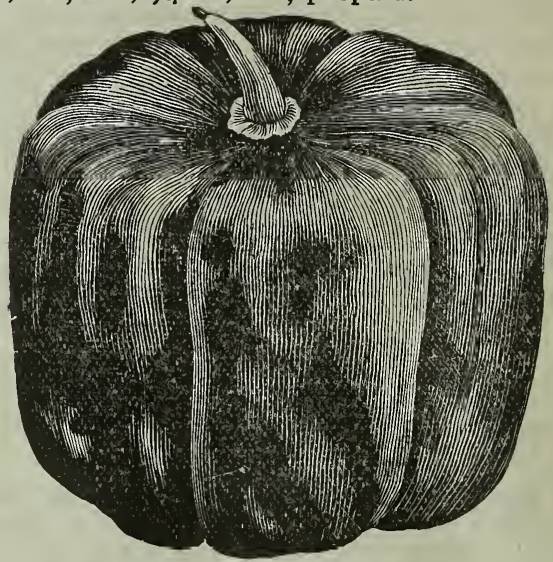

Improved Bull Nose or Sweet Mountain.

Chinese Giant Pepper-One of the very largest and best mango peppers, mammoth size, splendid shape, bright glossy pods, mild flavor. Bushes literally loaded. Bearing early and continuing to bear until frost. Very shy seeder. Pkt., 10c; I/4 oz., 15c; $1 / 2$ oz., 25c; oz., 40c; $\mathrm{T} / 4$ lb., $\$ 1.25$.

Ruby King-The peppers are of a bright ruby red color, from $4 \frac{1}{2}$ to 6 inches long, by $3 \frac{1}{2}$ to 4 inches in diameter. Flavor mild, and can be sliced and eaten with pepper and vinegar like tomatoes. Pkt., $5 \mathrm{c} ; \mathbf{o z}$., 25c; I/4 1b., 75c, prepaid.

Celestial-A beautiful and attractive plant; the peppers, up to the time when they are fully grown, are of a delicate creamy yellow color, and when fully grown change to an immense vivid scarlet, making the plant, when loaded with fruit, part of one color and part of the other-very attractive. Pkt., 5c; oz., 25c; I/4 lb., 75c, prepaid.

Spanish Monstrous-Fruit very large, often 8 inches or more in length by 2 or 3 inches in diameter; rind thick and fleshy; mild and sweet flavored. Pkt., 5c; oz. $25 \mathrm{c}$; $1 / 4$ lb., $75 \mathrm{c}$, prepaid.

Large Mexican Chile-This is the pepper sold so largely in the manufacturing of Chile Con Carne. Grows extensively in Southern Texas and Old Mexico and is more of a tropical pepper and will only produce green peppers in our climate. Pkt., 5c; oz., 15c; I/4 lb., 25c; Ib., $75 \mathrm{c}$.

\section{SEED POTATOES-Northern Grown}

\section{Write for prices on large lots. Subject to market changes.}

We commence shipping as soon as danger of frost is over, but will ship when requested at any time when customers wish to take their own risk.

Potatoes may be grown in any ordinary soil, but do best in sandy loam. Ten bushels cut tubers to the acre.

We offer the following standard varieties, all Northern grown.

Extra Early Ohio-The main potato for early planting; with the exception of the Early Triumph, this is the earliest potato grown. Pk., 40c; bu., $\$ 1.50 ; 2$ bu. sacks, $\$ 2.75 ; 10$ bu. lots, $\$ 1.35$ per bushel.

Early Triumph-The earliest potato grown, and one that every gardener should plant at least a few of for early market. Potatoes are of a medium size; color is a light red; round and uniform in shape. Pk., $40 \mathrm{c}$; bu., $\$ 1.50 ; 2$ bu. sacks, $\$ 2.75 ; 10$ bu. lots, $\$ 1.35$ per bushel.

Early Rose and Burbank Late-I/4 bu., $35 \mathrm{c}$; $1 / 2$ bu., $65 \mathrm{c} ; 2$ bu. sacks, $\$ 2.75 ; 10$ bu. lots, $\$ 1.20$ per bushel. 


\section{PEAS}

NOTICE-The pea crop is the shortest it has been for many years. You should order as early as possible before stocks are broken. When varieties ordered are sold out we will send the nearest type to peas ordered unless you state on your order not to do so.

Harnden's Extra Early-For years this pea has been grown in and around Kansas City by the market gardeners with the best of success. Seeds round; pods well filled, and ripen uniformly; height, $21 / 2$ feet; seeds white and slightly dented. Pkt., 10c; pt., 30c; qt., 50c, prepaid; pk., $\$ 2.00$, not prepaid.

American Wonder-The earliest of the winkled sorts; grows about nine inches high, and is covered with well filled pods, often containing seven or eight tender and sweet peas. Pkt., 10c; pt., 35c; qt., 50c, prepaid; pk., \$2.25, not prepaid.

Alaska-One of the earliest, which, in evenness of growth of vine and early maturity of pods, is unequaled by any other extra early pea Vines 2 to $2 \frac{1}{2}$ feet high, bearing four to sever long pods which are filled with medium sized bright green peas. Pkt., 10c; pt., 30c; qt., 45c prepaid; pk., $\$ 2.00$, not prepaid.

Nott's Excelsior-It resembles the Americar Wonder, but the vines are larger and more vig. orous. Pkt., $10 \mathrm{c}$; pt., $35 \mathrm{c}$; qt., $50 \mathrm{c}$, prepaid; pk. $\$ 2.25$, not prepaid.

New Telephone - Seed green, wrinkled height about four feet; foliage luxuriant, pe culiar light shade of green; pods unusually large, elegant shape, slightly curved, well filled with peas of large size. A most desirable variety for those who wish a large, showy pea. Pkt., 10c; pt., $35 \mathrm{c}$; qt., 50c, prepaid; pk., $\$ 2.25$, not prepaid.

Gradus or Prosperity-The earliest large podded pea in cultivation; the immense pods are as large as those of the Telephone; uniformly well shaped, nearly round ard well filled with large, handsome peas. The vine has heavy stems, with large dark green leaves; grows 3 feet in height. Pkt., 10c; pt., 35c; qt., 50c, prepaid; pk., \$2.25, not prepaid.

Harnden's Electric-This pea has steadily gained in popularity and is today the earliest wrinkled pea on the market. Pods are large, very broad, filled with large, tender peas of a most delicious flavor. It is a dwarf wrinkled pea and should be classed among the extra earlies. Height 12 inches. Pkt., 10c; pt., $35 \mathrm{c}$; qt., 50c, prepaid; pk., \$2.25, not prepaid.

Admiral Dewey-The very best, long podded, large vine, wrinkled pea yet introduced. Pods of the largest size, frequently 6 inches in length, rounded in point, deep green in color and well filled with large peas of the richest flavor; height $31 / 2$ feet. Pkt., 10c; pt., 35c; qt., 50c, prepaid; pk., $\$ 2.25$, not prepaid.

Thomas Laxton-Closely resembles the Gradus in habit and rapidity of growth. It is one of the finest early large podded peas, in earliness within a day or two of the earliest of all, containing seven or eight very large peas of the richest flavor. Height 3 to $31 / 2$ feet, and one of the finest ever introduced. Pkt., 10c; pt., $40 \mathrm{c}$; qt., $60 \mathrm{c}$, prepaid; pk., $\$ 2.50$, not prepaid.

Ameer-Resembling Alaska in manner of growth, but a week to ten days later, the greatest difference being in the size of the pod, which is much larger and slightly curved. Seed, green; smooth; height $21 / 2 \mathrm{ft}$. Pkt., 10c; pt., $30 \mathrm{c}$; qt., $45 \mathrm{c}$, prepaid; pk., $\$ 2.00$, not prepaid. 


\section{PUMPKIN}

One pound for 200 to 300 hills; four pounds per acre.

King of the MammothThis is the genuine strain of the True Mammoth Pumpkin. The largest pumpkin grown, often attaining a weight of 200 pounds and over. The flesh and skin are of a bright, golden yellow color, of excellent quality and a splendid keeper. Pkt., 5c; oz., $10 \mathrm{c} ; \mathrm{I} / 4$ lb., 30c; 1b., $\$ 1.00$, prepaid.

Sweet Potato-Pear shaped, size medium; creamy white in color, sometimes striped with green; flesh fine grained and very sweet. Pkt., 5c; oz., 10c; 1/4 1b., 25c; lb., $80 c$, prepaid.

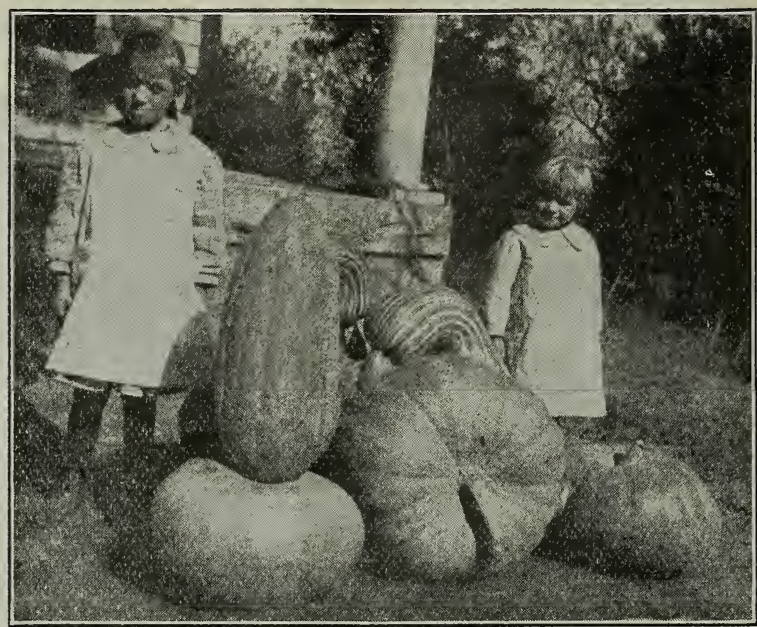

Small Sugar-Handsome and prolific; of small size, averaging about 10 inches in diameter. Skin deep

\section{RADISH}

\section{Harnden's French Grown Seed}

Culture-For the first crop sow as early in the spring as the ground can be worked, and every two weeks throughout the season for a succession. A warm, sandy loam, made rich and light by some good strong manure will be most likely to afford them brittle and free from worms. Sow in drills ten to twelve inches apart. The winter varieties should be sown in July and August. Like the turnip, they make the best growth in the autumn, and must be taken up before frost and stored away in a cool cellar in sand, or a pit, where they will keep tender and crisp all winter.

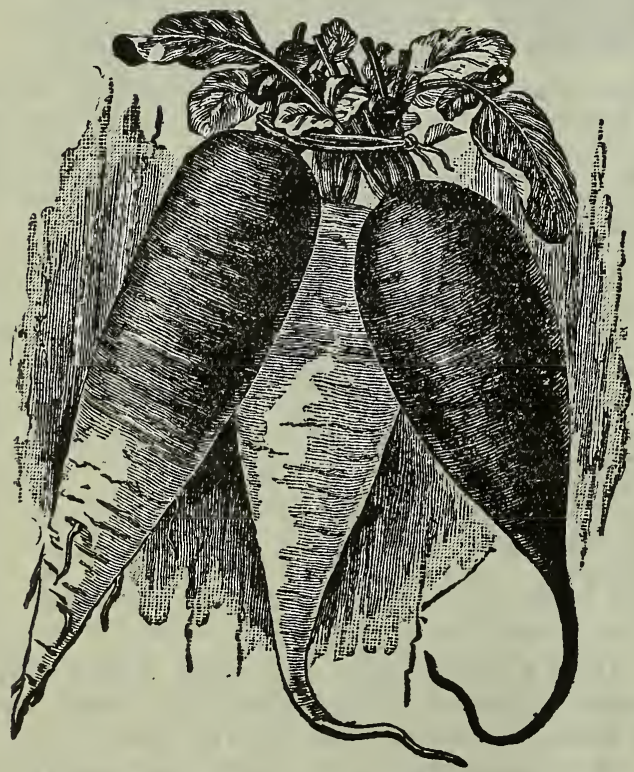

Improved Chartier. Wood's Early Frame. White Strasburg. orange yellow. Fine grained, sweet, dry and an excellent keeper; a good table variety. Pkt., 5c; oz., 10c; r/4 1b., 20c; lb., 60c, prepaid.

Connecticut Field-One of the best for field culture; can be grown with corn, largely used for stock feeding. Deep, rich yellow color. Oz., 10c; $1 / 4$ lb., $15 c$; lb., 40c, prepaid.

Large Cheese or $\mathbf{K y}$. Field-A popular variety in the South. Fruit flattened skin mottled light green and yellow; flesh tender; oz., 10c; r/4 lb., 15c; 1b., 40c.

Cushaw-A prolific variety; large size, frequently weighing 60 pounds and over; color, white striped and mottled with green. Pkt. 5c; oz., 10c; I/4 lb., 20c; lb., 60c, prepaid. excellent quality. Pkt., 5c;

Aarnden's Early Scarlet Globe-A desirable turnip sort for hot-bed forcing and out-doors; very early; flavor mild, crisp, juicy and tender; top small; will stand heat, without becoming pithy. One of the best selling and most attractive radishes on account of its bright scarlet color and handsome shape; is ready in 28 days. Our stock of this is the very best, selected with special care as to size, shape, color and earliness. Pkt., 5c; oz., $10 \mathrm{c}$; $1 / 4 \mathrm{lb}$., 20c; 1b., $60 \mathrm{c}$, postpaid; 5 lbs., by express, not prepaid, $\$ 2.50$.

\section{Three Good Turnip Varieties}

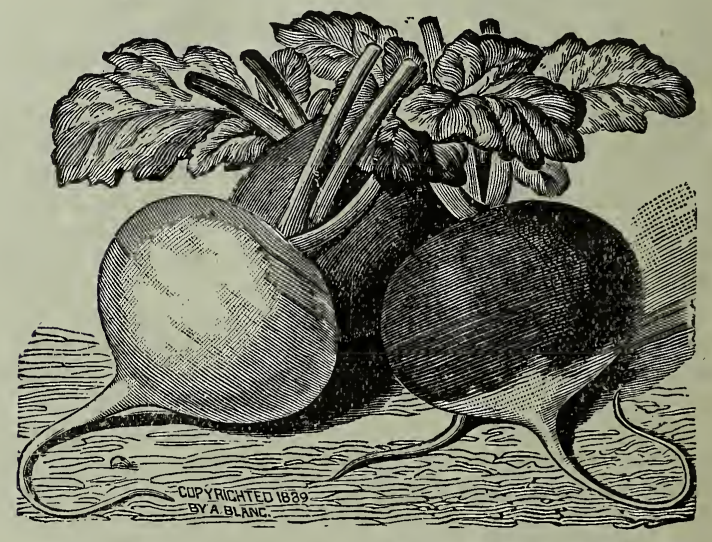

$$
\begin{gathered}
\text { White Turnip. Early Deep Scarlet. } \\
\text { Scarlet White Tip. }
\end{gathered}
$$

Harnden's Selected Early Scarlet Turnip, White Tipped-This is the most important sort for out-door sowing. Our market gardeners plant hundreds of pounds of this variety each year. The color is just right and the size always asked for by the hotels and grocers. Pkt., 5c; oz., 10c; I/4 lb., 20c; 1b., 60c, prepaid; 5-lb. lots, not prepaid, $\$ 2.50$. 


\section{RADISH-Continued}

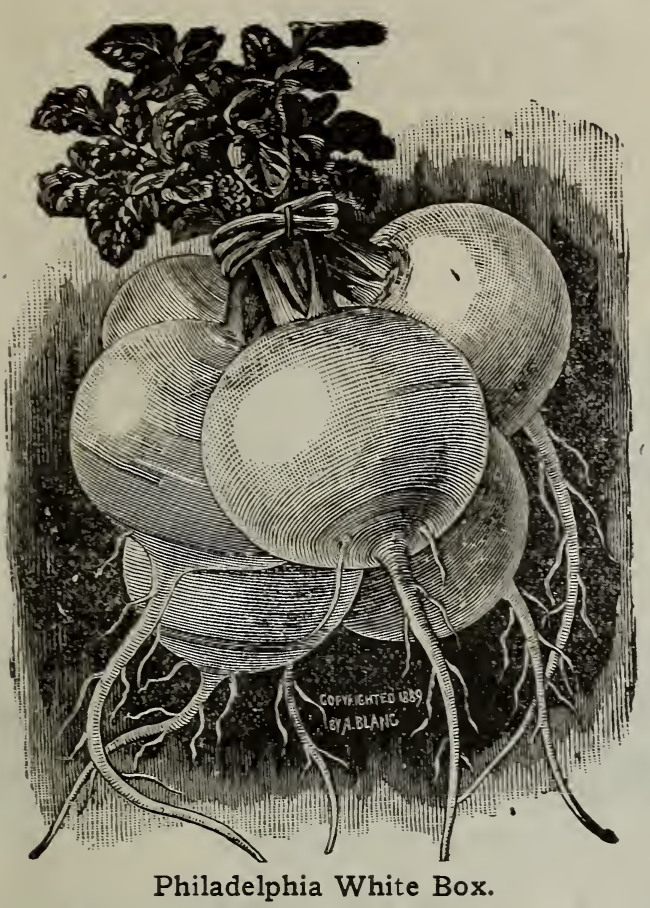

Improved Chartier-The color at the top is crimson running into pink about the middle, and from thence down it is a pure waxy white; it is of quick growth, and does not become stringy. Pkt., 5c; oz., 10c; $1 / 4$ ld., 20c; lb., $60 \mathrm{c}$, postpaid.
White Strasburg-A leading sort on our market; half long in shape; both skin and flesh pure white, firm and brittle; grows to a large size and withstands severe heat. Pkt., 5c;. 0z., 10c; I/4 lb., 20c; 1b., 60c, postpaid.

Extra Early Deep Scarlet Turnip, White Tipped, Forcing-A beautiful variety, deep scarlet with white tip; popular as a market variety. Does not show as much white as the ordinary Scarlet T. W. Tip. Pkt., $5 c ; 0 z$., 10c; $1 / 4$ lb., 20c; 1b., 60c, postpaid; 5 ibs., not prepaid, $\$ 2.50$.

Philadelphia White Box-Roots round and smooth, very white and handsome; remains solid and juicy long after full grown; desirable for forcing but a splendid out-door radish as well. Pkt., 5c; 0z., 10c; $1 / 4$ lb., 20c; lb., 60c, postpaid.

Crimson Giant Globe-The best radish for forcing or early planting out of doors, will grow larger and remain solid longer than any other round red forcing radish. Pkt., 5c; 0z., 10c; 1/4 lb., 25c; 1 lb., $75 \mathrm{c}$.

Wood's Early Frame-This variety is similar in shape to the Long Scarlet, but shorter and fully ten days earlier; much used for forcing. Pkt., $5 c ; 0 z ., 10 c ; 1 / 4 \mathrm{lb}$., $20 \mathrm{c}$; 1b., 60c, postpaid.

Long White Vienna or Lady Finger-This is one of the finest long radishes, beautiful in shape, skin and flesh pure white. Pkt., 5c; oz., 10c; I/4 lb., 20c; lb., 60c, postpaid.

Icicle-The earliest and finest long white radish. The young radishes are ready for use even earlier than the long scarlet and continue to grow for a long time, fully retaining their tenderness and mild flavor until quite large. Pkt., 5c; 0z., 10c; $1 / 4$ lb., 25c; lb., 60c, postpaid.

Rose China Winter-One of the best fall and winter varieties, a favorite with market gardeners; bright rose color, flesh white, firm and of superior quality. Pkt., $5 c$; oz., 10c; $1 / 4$ lb., 25c; lb., 70c.

\section{Standard Varieties}

Early White Turnip

Early Deep Scarlet Turnip.

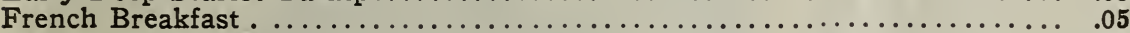

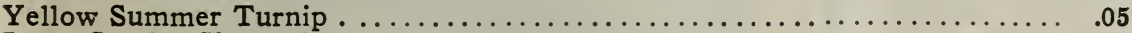

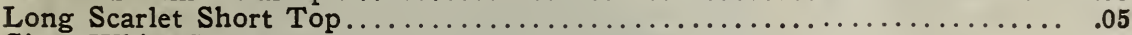

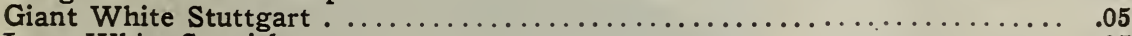

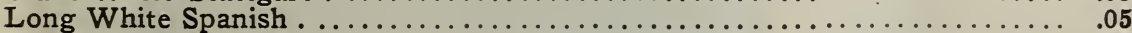

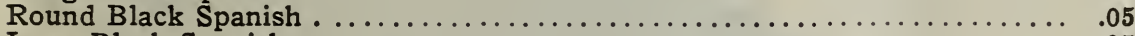

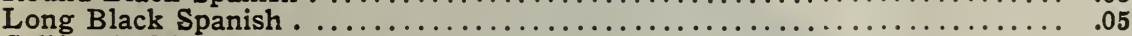

California Mammoth White Winter.....................................

Chinese Celestial.
Pkt.

$\$ 0.10 \$ 0.20$

$.10 \quad .20$

$.10 \quad .20$

$.10 \quad .20$

$.10 \quad .20$

$.10 \quad .20$

$.10 \quad .20$

$.10 \quad .25$

.10

.10

.10
.25

.25

.25
Not Prepaid

lb. $5 \mathrm{lb} .10 \mathrm{lb}$.

$\$ 0.60 \quad \$ 2.50 \quad \$ 4.50$

$\begin{array}{lll}60 & 2.50 & 4.50\end{array}$

$\begin{array}{lll}.60 & 2.50 & 4.50\end{array}$

$\begin{array}{lll}.60 & 2.50 & 4.50\end{array}$

$\begin{array}{lll}.60 & 2.50 & 4.50\end{array}$

$\begin{array}{lll}.60 & 2.50 & 4.50\end{array}$

$\begin{array}{lll}.65 & 2.65 & 4.75\end{array}$

$\begin{array}{lll}.70 & 2.75 & 5.00\end{array}$

$\begin{array}{lll}.75 & 2.75 & 5.00\end{array}$

$\begin{array}{lll}.70 & 3.00 & 5.00\end{array}$

$\begin{array}{lll}.75 & 2.75 & 5.00\end{array}$

\section{RHUBARB .}

Culture-Sow in drills one foot apart, one inch deep, when a few inches high, thin to a foot apart. In fall or spring prepare the ground for the final bed by trenching two feet deep, mixing a liberal quantity. of manure with the soil. Set the plants three feet apart each way.
Linnaeus-The earliest for market purposes. Pkt., $5 c ; 0 z ., 10 c ; 1 / 4$ lb., 35c; lb., $\$ 1.25$.

Victoria-Large and tender. Pkt., $5 \mathrm{c}$; oz., 10c; $1 / 4$ lb., $35 \mathrm{c}$; lb., $\$ 1.25$.

Roots-Not prepaid, dozen, $\$ 1.00$; each, 10c; prepaid, $15 \mathrm{c}$ each; $\$ 1.50$ dozen. 


\section{SPINACH}

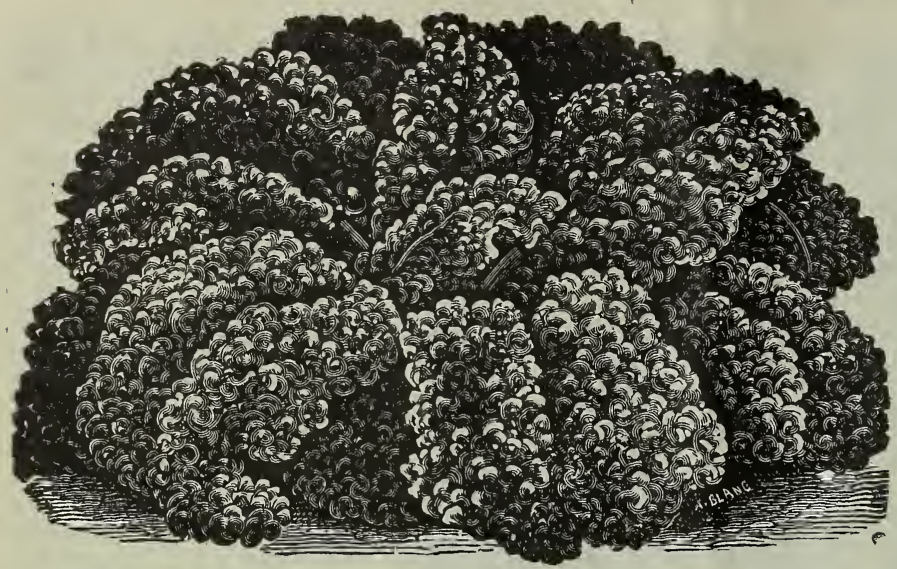

Bloomsdale or Savoy Leaved.
Pkt., 5c; oz., 10c; $1 / 4$ lb., 15c; 1 lb., 35c, prepaid; 5 lbs., $\$ 1.00 ; 10$ lbs., $\$ 1.75$, not prepaid.

Round Leaf Virofly-A variety with large thick leaf, matures quickly; a good market sort. Pkt., 5c; 0z., 10c; $1 / 41 \mathrm{lb} ., 15 \mathrm{c} ; 1 \mathrm{lb}$., 35c, prepaid; 5 lbs., $\$ 1.00 ; 10$ lbs., $\$ 1.75$, not prepaid.

\section{SALSIFY}

Culture-It succeeds best in a light, well enriched soil; coarse and fresh manure should be avoided, as it will surely cause the roots to grow uneven and ill-shaped. Sow the seeds as early as possible, and quite deep in drills about eighteen inches apart, and thin the plants to three inches in the row.

Mammoth Sandwich Island-This variety grows to an extra large size, averaging fully double the size and weight of roots of the old French variety. Pkt., 5c; oz., 15c; $1 / 4 \mathrm{lb} ., 35 \mathrm{c}$.

Don't forget that we always are willing to send samples. Write for them.

Culture-Spinach is an important market gardener's crop, of easy culture. For spring and summer use, sow in drills one foot apart and one inch deep, as early as the ground can be worked, and every two weeks for a succession. For winter and early spring use, sow in September in well manured ground; cover with straw on the approach of severe cold weather. The ground cannot be too rich; the stronger the ground the more delicate and succulent will be the leaves. The New Zealand Spinach, which requires more room, as it makes a large and spreading plant, may be started from seed early in the spring to give greens during the heat of summer. Light applications of nitrate of soda have often a magic effect on spinach.

Thick Leaved Round-Good for either fall or spring sowing; very hardy; leaves large, round, thick. Pkt., 5c; oz., $10 \mathrm{c}$; $\mathrm{x} / 4 \mathrm{lb}$., 15c; 1b., 35c, postpaid; 5 lbs., $\$ 1.00$, $10 \mathrm{lbs}$., $\$ 1.75$, not prepaid.

Bloomsdale or Savoy-Leaved-Leaves large, curled and wrinkled like Savoy cabbage, very hardy. Pkt., 5c; oz., 10c; $1 / 4$ lb., $15 \mathrm{c}$; lb., 35c, postpaid; 5 lbs., $\$ 1.00 ; 10$ Ibs., $\$ 1.75$, not prepaid.

Long Standing-Standard with gardeners; leaves thick, fleshy and crumpled, round, large and of a dark green color; slow to run to seed. Pkt., 5c; oz., 10c; $1 / 4$ lb., 15c; lb., 35c, postpaid; 5 lbs., $\$ 1.00,10 \mathrm{lbs}$., $\$ 1.75$, not prepaid.

Prickly Winter-Matures a little earlier than the round leaf sorts; very hardy, good for winter planting.

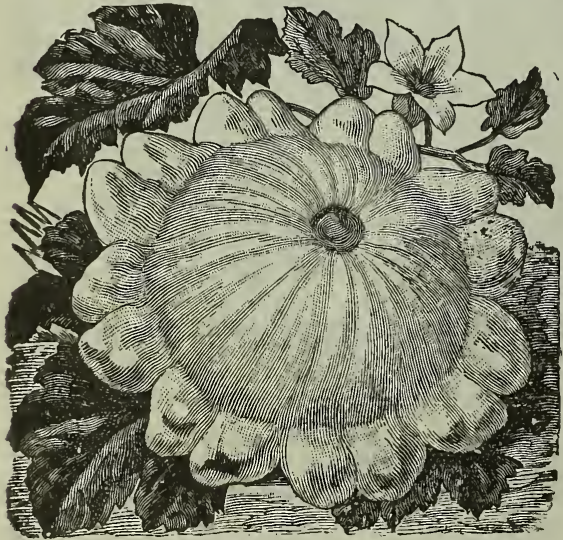

Mammoth White Bush.

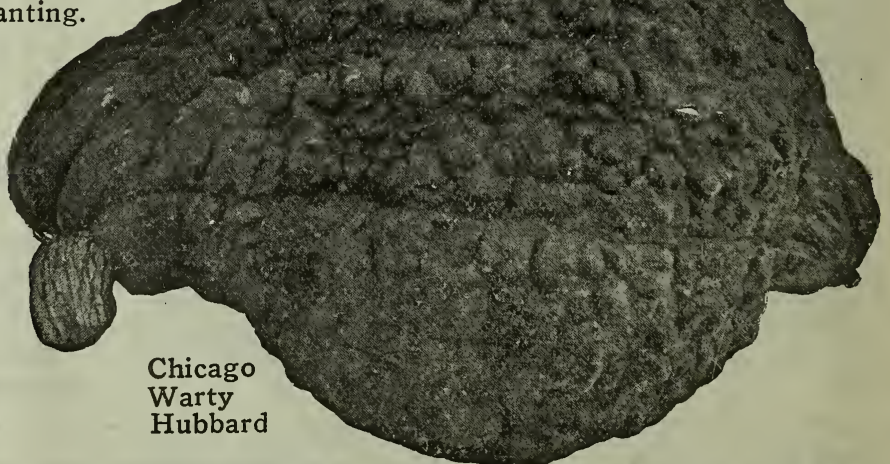

Chicago Warty Hubbard-The principal late squash for commercial purposes. An improvement on the old Hubbard. Skin heavily warted. The best late squash to plant for general crop. Pkt., $5 c$; oz., $10 \mathrm{c} ; 1 / 4 \mathrm{lb}$., 30c; lb., $\$ 1.00$, prepaid. 


\section{TOMATOES}

\section{Harnden's Selected Tomato Seed}

Culture-Tomatoes do best on not over rich, warm soil, and success depends upon securing a rapid, vigorous and unchecked growth during the early part of the season. Even a slight check while the plants are small will materially diminish their productiveness. Sow the seed in hot-beds or seed boxes, and when the plants have four leaves, transplant into shallow boxes or coldframes.

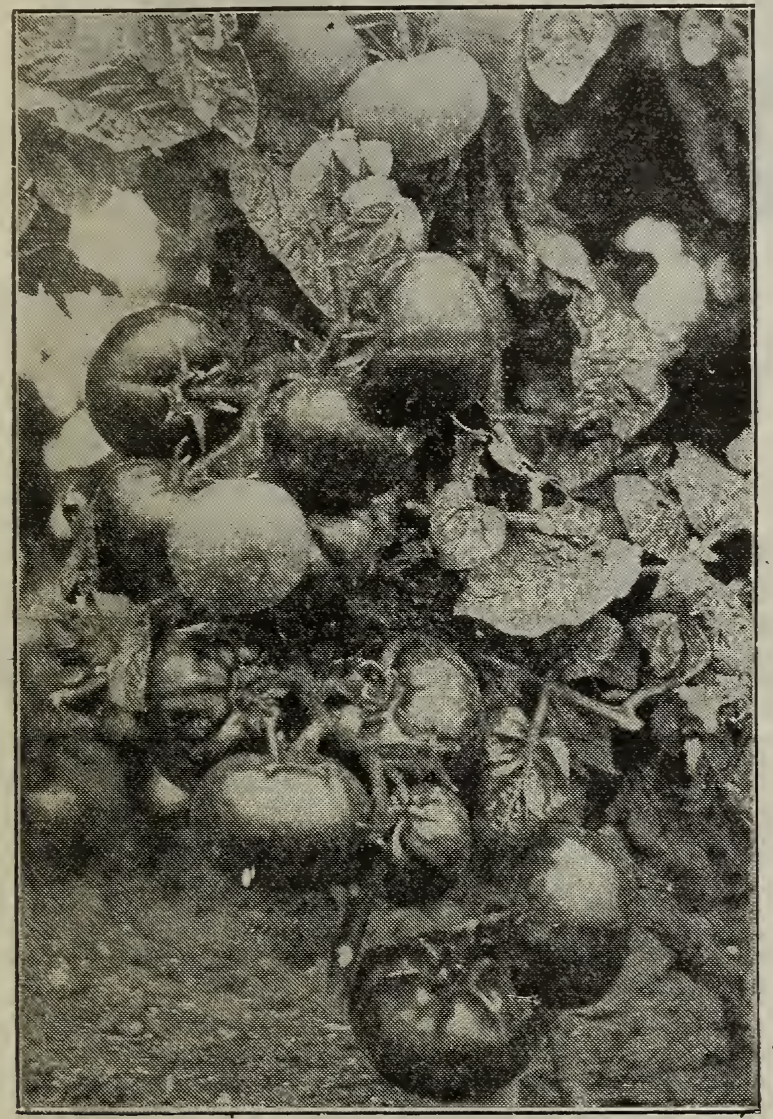

Dwarf Stone (Livingston's).

Double the Size of Dwarf Champion.

The Largest Dwarf in Existence.

Livingston's Globe-Beautiful globe shape; among the first to ripen, although of large size; smooth, firm fleshed; few seeds; ripens evenly; color a beautiful glossy rose, tinged purple; flavor delicate and agreeable; splendid slicing variety; borne on short-jointed branching plants in great abundance, literally loaded with fruit; a good general cropper; an entirely distinct and fixed new sort. Pkt., 10c; 3 pkts., 25c; oz., 35c; 1/4 lb., \$1.00.

Buckeye State-One of the largest fruited varieties grown; smooth and uniform; heavy cropper; grows in clusters of from four to ten fruits; color glossy dark crimson, with slight tinge of purple; matures about the same time as the Stone. Pkt., 5c; oz., 25c; $1 / 4$ lb., $75 c$.

Matchless-A large, bright red tomato; fruit large, smooth and symmetrical; flesh bright red color. Pkt., $5 c$; oz., 25c; $1 / 4$ lb., 75c.
Livingston's Dwarf Stone Tomato-In habit of vine it resembles Dwarf Champion, but is of stronger growth and more erect. The fruit resembles Livingston's Stone in color, shape, and is practically the same size; double the size of Dwarf Champion, yet equally as early; more productive. Pkt., 10c; oz., 30c; $1 / 4$ lb., $85 \mathrm{c}$.

New Stone-Large, smooth tomato; color bright scarlet; ripens evenly on the stem; solid, an excellent shipper, very productive; fine for canning; a general favorite with all who have used it. Pkt., 5c; oz., 20c; $1 / 4$ 1b., 50c.

Dwarf Champion-The best early tomato grown; entirely distinct in habit of growth and foliage; vines are dwarf and compact, grow stiff and upright, with thick, short-jointed stems. Pkt., $5 \mathrm{c}$; oz., $30 \mathrm{c} ; \mathrm{I} / 4 \mathrm{lb}$., $75 \mathrm{c}$.

Livingston's Beauty-True stock grows in clusters of four or five; glossy crimson, partaking of some of the characteristics of the Acme; retains its color and size until late in the season. Pkt., $5 \mathrm{c} ; 0 \mathrm{z} ., 25 \mathrm{c} ; \mathrm{I} / 4 \mathrm{lb}$., $70 \mathrm{c}$.

Spark's Earliana Tomato-This tomato has become very popular with many growers of tomatoes for early market; it is a very excellent early variety, good size, good color, twice as many plants can be grown on an acre of this variety than any other variety grown. Pkt., $5 \mathrm{c}$; oz., $30 \mathrm{c} ; \mathrm{r} / 4 \mathrm{lb}$., $75 \mathrm{c}$.

Trucker's Favorite-The finest large-fruited purple tomato. Most regular in form and size; thick-meated and very solid; this is one of the largest smooth tomatoes grown. Well ripened throughout. The smooth flesh fruits always bring the highest prices on our Kansas City market, where their fine flavor is especially esteemed. 'The fruits continue of large size to the very last, and are always unexcelled for slicing or cooking. Pkt., 5c; oz., 30c; $1 / 4 \mathrm{lb}$., 85c.

Crimson Cushion or Beefsteak-Fruit large; color bright scarlet, flesh solid and of good quality; cells small and few in number; very productive; fruit finely formed and of handsome appearance. Pkt., $5 \mathrm{c} ; 0 z ., 30 \mathrm{c} ; \mathrm{I} / 4 \mathrm{lb}$, $75 \mathrm{c}$.

Large Red Trophy-Rich red color, very productive, smooth, fine grained fruit, strong, vigorous growing vine. One of the best late tomatoes. More largely used by canners than any other variety. Pkt., 5c; oz., 20c; $\mathrm{r} / 4 \mathrm{lb} ., 50 \mathrm{c}$.

Acme-The earliest, well-known, bright pink tomato .....................\$0.20 \$0.60

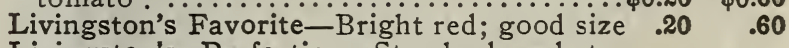

Livingston's Perfection-Standard red to-

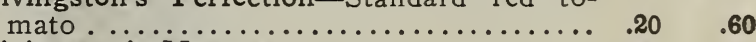

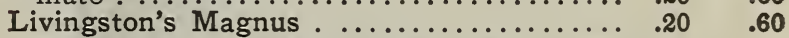

Royal Red-Large, smooth red; heavy cropper ........................... .20

Ponderosa-The largest tomato in cultiva-

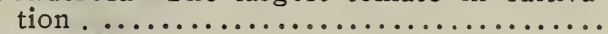

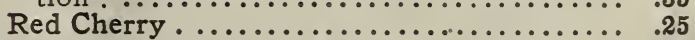

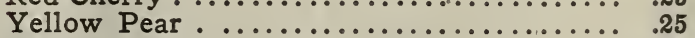

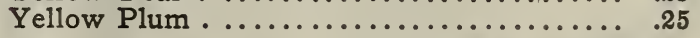
.60

We carry Tomato Plants in Season at Our Retail Stores

1418 Grand Ave. and 505 Walnut St.

Receiving them Fresh Every Morning

From the Seed Beds 


\section{RUTABAGAS}

Culture-Sow the seeds about a month earlier than turnips. Rutabagas should be sown on ground enriched with well-rotted manure, in drills $2 \mathrm{r} / 2$ feet apart, and should be thinned to 6 to 8 inches apart in row.

Improved American Purple-Top-Leading yellow variety; very productive, solid and of excellent flavor; the roots grow to a large size, and are of the finest quality; unsurpassed for stock feeding. Pkt., 5c; Oz., 10c; $1 / 4$ lb., 20c; lb., 60c, postpaid; by express, 5 lbs., $\$ 2.25$.

\section{TOBACCO SEED}

The tobacco Seed we offer has been carefully grown on crown shoots only, and improved by continuous selection. It will be found true to name and of the highest vitality. "Virginia Grown."

Yellow Oronoko-Used for first-class plug fillers, and makes, when sun-cured, the best Natural Chewing Leaf; a favorite wherever known. Pkt., 10c; oz., 30c; $1 / 4$ lb., 75c.

White Burley-This variety is especially valuable to manufacturers, either for cut or plug tobacco. It is sometimes used for wrappers. Pkt., 10c; oz., 60c; I/4 lb., $\$ 1.50$.

Connecticut Seed Leaf-The largest, best and finest variety of this indispensable kind. Pkt., 10c; oz., 25c; r/4 lb., 75c.

Big' Havana-A hybrid Havana or Cuban seed leaf; a heavy cropper of fine texture, delightful flavor and the earliest cigar variety to mature. Pkt., 10c; oz., 60c; I/4 lb. $\$ 1.50$.

Missouri Broad Leaf-Extensively grown in Kansas and Missouri; the large broad leaves are used for the wrappers. Pkt., 10c; 0z., 30c; I/4 lb., $\$ 1.00$.

\section{AROMATIC, MEDICINAL AND POT HERBS}

Varieties marked with an * are perennials.

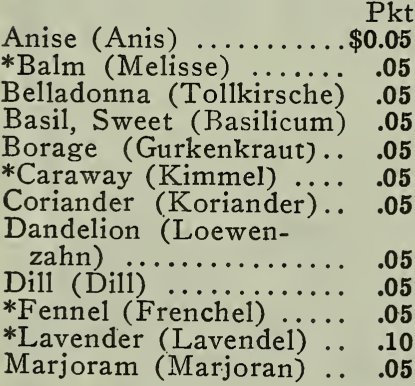

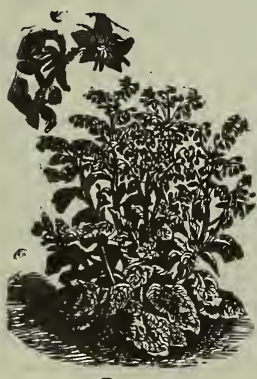

Sage.

Oz.
$\$ 0.10$
.25
.30
.15
.15
.10
.10
.25
.10
.20
.35
.15

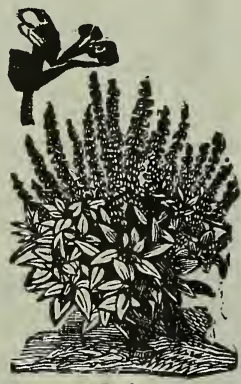

Majoram.
*Rosemary (Rosmarin) ..\$0.05 $\$ 0.40$ Rue (Route) ......... .05 .25 Sage (Salbei) I/4 1b., 50c; .05 .15 Saffron (Safron) kraut.. $.05 \quad .20$ *Summer Savory Bohnen . .............. .05 .20 Sorrel (Sauerampfer) .. *Thyme (Thymian) .... $\quad .10 \quad .30$ *Wormwood (Wermuth) $\quad .05 \quad .20$

Martynia

Martynia Proboscidea-For pickling. Plkt., 5c; Oz., 30c; I/4 lb., $\$ 1.00$.

TURNIP

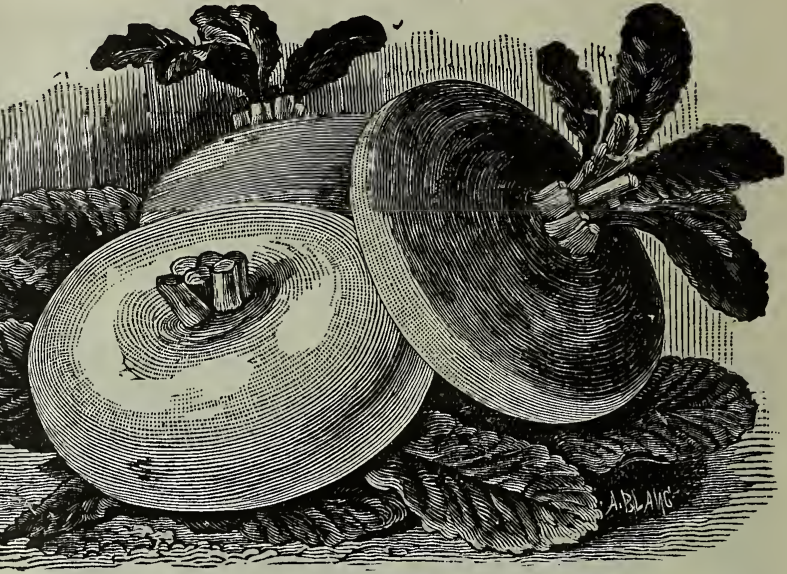

White Flat Dutch. Purple Top Strap-Leaf.

Extra Early Red-Top Milan-The earliest strap-leaf variety, maturing a week earlier than any other sort; bulbs white, purplish top; flat and solid. Pkt., 5c; oz., 10c; I/4 lb., 25c; 1b., 75c.

Early White Egg-Pure white, egg-shaped, rapid grower and fine quality. Pkt., $5 \mathrm{c}$; oz., 10c; I/4 1b., 25c; lb., 65c, postpaid.

Purple-Top Strap-Leaf-The most popular variety grown. Pkt., 5c; oz., 10c; I/4 lb., 20c; lb., 60c, postpaid; by express, 5 lbs., $\$ 2.25$.

Early White Flat Dutch-A popular, well-known early sort; the best variety for spring sowing. Pkt., 5c; oz., 10c; I/4 lb., 20c; 1b., 60c, prepaid; by express, 5 lbs., \$2.25.

Purple-Top White Globe-Improved variety of Purple Strap-Leaf, globular shaped; smooth and a favorite sort for market gardeners. It keeps well, and is excellent for early or winter market. Pkt., 5c; oz., 10c; I/4 1b., 20c; 1b., 60c; by express, 5 lbs., \$2.25.

Pomeranian White Globe-Valuable both for stock feeding and for table use; the roots will frequently grow to 12 lbs. in weight. Pkt., 5c; oz., 10c; $1 / 4$ lb., 20c; 1b., 50 c, postpaid; by express, 5 lbs., $\$ 2.00$.

Seven-Top or Forester (Winter Green)-Used extensively in the South for winter greens; does not produce a good bulb; desirable only for its tops; is very hardy and will grow all winter. Pkt., 5c; oz., 10c; I/4 1b., 20c; lb., 60c, postpaid.

Amber Globe-Yellow flesh, firm, fine grain; very sweet; skin yellow, with green top; keeps well; very popular in the South. Pkt., 5c; oz., 10; I/4 1b., 20c; 1b., 50c, postpaid; by express, 5 lbs., $\$ 2.00$.

If You Wish to Buy Turnips in Large Lots for Fertilizing Purposes Ask for Prices

\section{: Plant Harnden's Seeds They Grow and Give You Entire Satisfaction}




\section{FLOWER SEEDS \\ New and Standard Varieties}

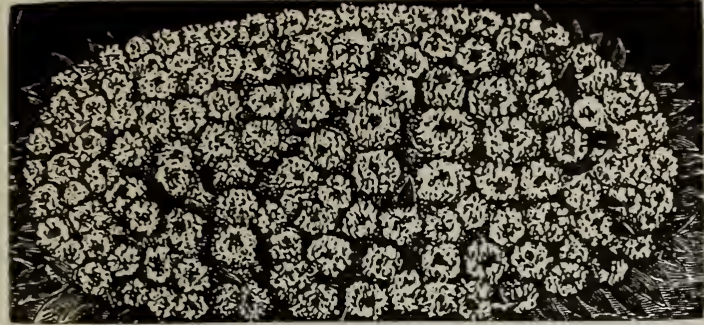

Alyssum-Little Gem or Carpet of Snow.

Prices on flower seeds are prepaid, either to go by mail or express.

While flower seeds will germinate in almost any kind of soil, they will not thrive or develop unless care is taken in the preparation of the seed beds. Dig the soil deep, thoroughly pulverize and liberally enrich with a large quantity of well rotted manure or good fertilizer. Make your seed bed as smooth and level as possible, and see that it is well drained so that no water will stand on it after a hard shower. Do not plant the seeds in the ground when it is wet.

Our flower seeds are put up in packets by ourselves, and our customers will find culture directions on the back of each packet.

A good rule to follow in planting flower seeds is to plant four times the depth of the diameter of the seed you are planting. Plant in rows so that the plants can be easily seen. Thin out the young plants if you find they are crowded when they come up. Keep as free from weeds as possible.

If a little care is taken along these lines you will have much better success with your flowers.

\section{Flowers from Seeds Are Usually Known as Annuals, Biennials and Perennials}

ANNUALS bloom and ripen seed the first year and then perish.

BIENNIALS do not generally flower the first season and are in perfection only one year.

PERENNIALS continue to flower for several years in succession. Many of them bloom the first year if sown early.

HARDY ANNUALS, Biennials and Perennials can be sown in the open ground early in the spring if desired, and Biennials and Perennials will not require any protection in winter.

HALF HARDY ANNUALS, Biennials and Perennials should not be sown in open ground until settled warm weather, though they can be sown in the house, if desired, early and afterwards transplanted. The two latter need to be protected in the winter, or carried over until spring in cold frames or greenhouses.

\section{Our.Flower Seeds Have All Been Tested and}

Will Give the Best of Satisfaction
AGERATUM-One of the best summer blooming plants grown from seeds. They are rapid growers, early and constant bloomers. Set the dwarf varieties 10 inches apart. Dark blue and white. Pkt., 5c; oz., 25c.

AQUILEGIA or Columbine-Hardy perennial plants, ornamental both in growth and flower and no bed of perennials would be complete without a due proportion of Columbine. Double white, pkt., 10c; Double purple, pkt., 10c; mixed, pkt., 5c.

ALYSSUM-Pretty little plants for beds, vases, edgings or rock work, with delicate white flowers of exquisite fragrance.

MARITIMUM-Very sweet scented. Oz., 30c; pkt., 5 cents.

ALYSSUM, Little Gem-This should really be called the Carpet of Snow. The plants are only about 2 inches high, but grow very dense and are completely covered with snow white blossoms from early summer until frost. Pkt., 5c; oz., 40c.

SAXATILE COMPACTUM-"Basket of Gold"Showy golden yellow flowers; hardy perennial; blooms the first season; excellent for rock work; $1 \mathrm{ft}$. Pkt., 10c; oz., 60c.

AMARANTHUS-Caudatus (Love Lies Bleeding)Pkt., 5c. Tricolor (Joseph's Coat)-Pkt., 5c. Splendens (Rainbow Plant)-Plants of upright growth; the inner foliage is of a dark, blackish bronze, while the outer foliage is an intense flaming crimson. Pkt., $5 \mathrm{c}$.

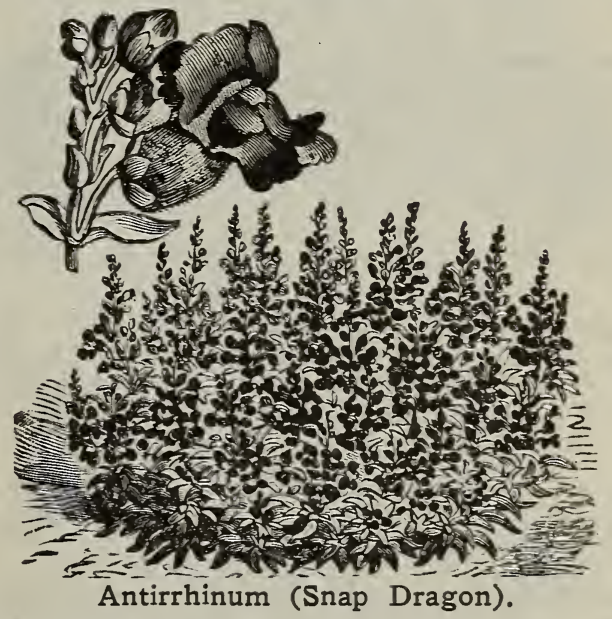

ANTIRRHINUM or Snap Dragon-An old garden favorite, with odd shaped flowers and pretty spotted throats; succeed in any good garden soil. They blossom the first season from seed sown in the spring.

Dark Scarlet-Pkt., 10c.

Coral Red-Pkt., 10c.

Queen Victoria-Very large, pure white. Pkt., 10c. Black Prince-Large flowers, almost black. Pkt., 10c. Galathee-Crimson and white. Pkt., 5c.

Delilah-White and carmine. Pkt., 5c.

Dwarf sorts, mixed. Pkt., 5c.

Tall varieties, mixed. $\mathrm{Pkt}$., $5 \mathrm{c}$. 


\section{ASTER}

It is unnecessary to dwell on the great beauty of these popular flowers, as they are appreciated by every one.

The seed may be planted out of doors as soon as the ground is warm and dry. Sow the seed at intervals until the last of June using different strains and you will have a succession of bloom until frost.

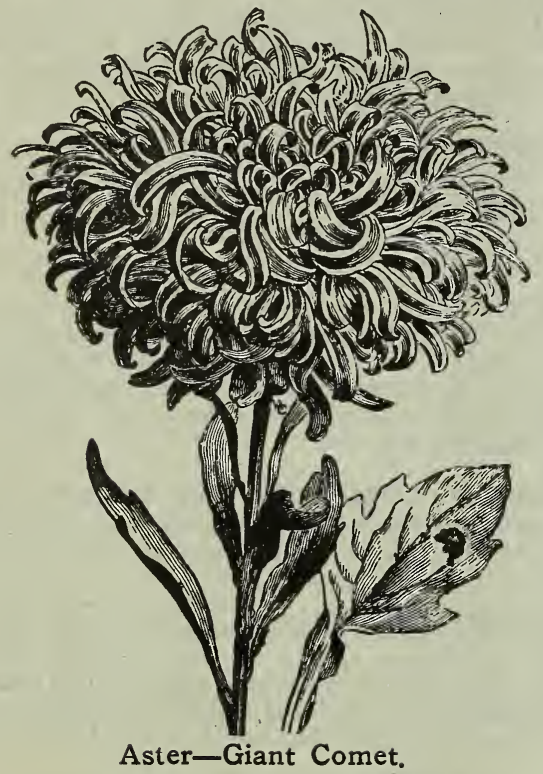

Giant Comet-The Comet Aster is well-known for its unique appearance, resembling the Japanese Chrysanthemums. The petals are longer and broader with the same beautiful wavy appearance of this class; 18 inches high; sulphur yellow, white, salmon rose, crimson, dark blue. Pkt., 10c; 3 for 25c; $1 / 8$ oz., 35c. Finest Mixed. 50c.

White Fleece-Large Comet shape. Pkt., 15c; 1/8 oz.,

Improved Victoria-Undoubtedly the finest Aster in cultivation; flowers large and perfectly double, $13 / 4$ feet high. Our strain of this variety is the very finest. Delicate pink, crimson, dark blue, white, violet purple, light blue. Pkt., 10c, 3 for 25c; $1 / 8$ oz., 50c.

Paeony Flowered Perfection-Large, brilliant, very double and inbricated, $1 \frac{1}{2}$ to 2 feet high; mixed. Pkt., $10 \mathrm{c}, 3$ for $25 \mathrm{c}$; $1 / 4$ oz., $50 \mathrm{c}$.

Giant Branching Aster-Beautiful aster for cut flowers, borne on long stiff stems; profuse bloomers; perfectly double; clear bright colors; deep violet, lavender, dark rose, pure white, shell pink, finest mixed. Pkt., $10 \mathrm{c} ; \mathrm{I} / 4$ Oz., $50 \mathrm{c}$.

Violet King-Soft violet, late branching habit, vigorous in growth, with long stiff stems; in form the flower is entirely new and distinct; petals somewhat resemble the quilled varieties, but are much larger and broader. Pkt., 10c; $1 / 8$ Oz., 50c.

Queen of the Market-The finest Dwarf Aster. It forms low bushy plants about ten inches high, of compact habit of growth, producing a great number of extra large flowers; fully two weeks earlier than other sorts. Mixed. Pkt., 10c; $1 / 8$ oz., 35c.
Dwarf Victoria Aster-Mixed colors; very beautiful, with large finely imbricate flowers. Pkt., 10c; $1 / 8$ oz., 25c.

Dwarf Comet Perfection Aster-Eight inches high, flowers early in July; flower five inches in diameter, petals well curled. Pkt., 10c; 1/8 oz., 25c.

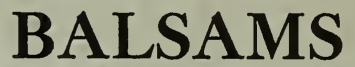

(Lady Slippers or Touch-Me-Not.)

To produce very double flowers they must be transplanted from the seed bed into rich soil; cut out some of the side branches when small. Sow the seed in March and transplant when three inches high. Plant in the open ground in May.

Balsam Double Camellia Flowered-Undoubtedly the showiest and most attractive variety of Balsam. Mixed colors. Pkt., 5c; $1 / 4$ Oz., 25 c.

Double Rose Flowered-Has perfectly double roselike blossoms of almost every shade and color. Mixed colors. Pkt., 5c; $1 / 4$ oz., 20c.

Balloon Vine (Love in a Puff) - A rapid growing climber, with peculiar inflated capsules. Pkt., 5c; $1 / 4$ oz., 25c.

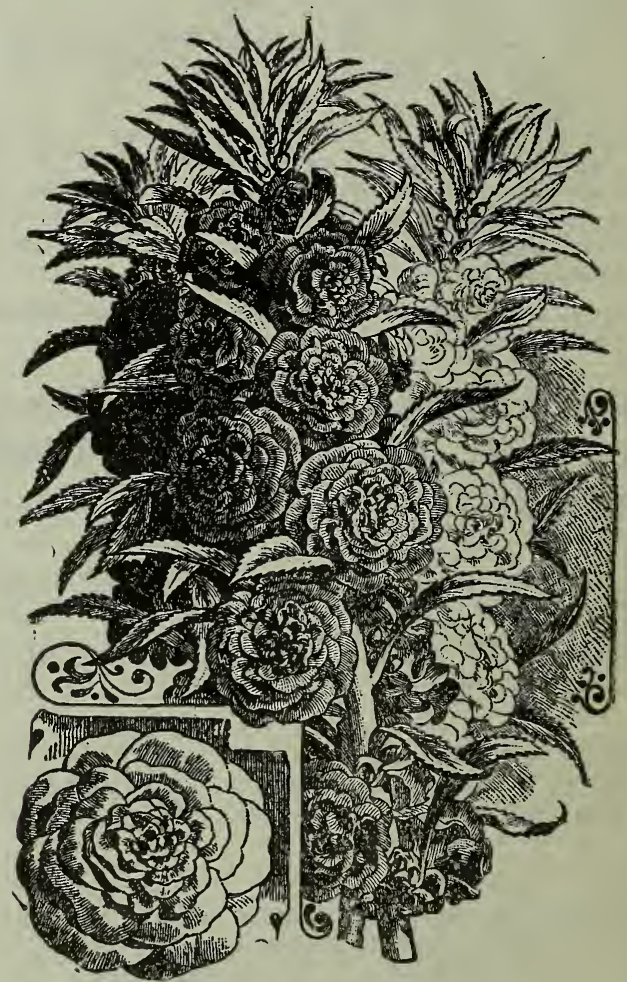

Balsam, Double Camellia Flowers.

YOUR LAWN SHOULD BE SOMETHING OF WHICH YOU ARE PROUD-Sow our Lawn Grass Mixture and you will be. Prices as follows: One pound, 35 cents; three pounds, $\$ 1.00$; bushel, $\$ 4.25$. If to $\mathrm{go}_{x}$ by mail add one-half cent per ounce. 


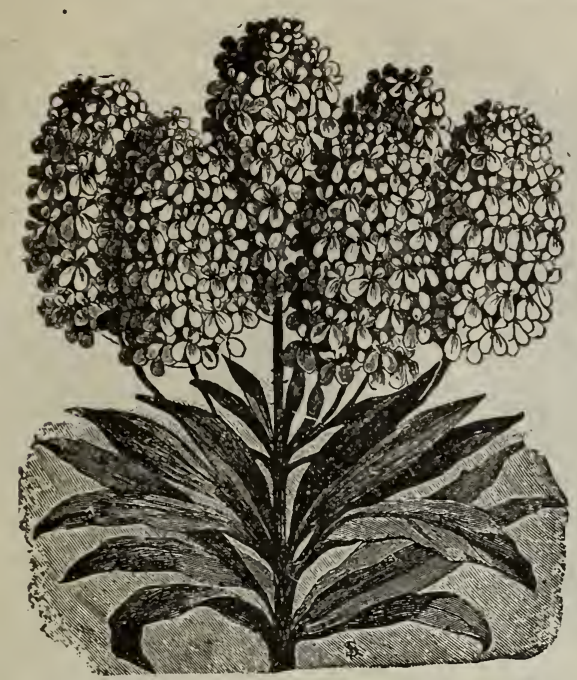

Candytuft-Giant Hyacinth Flowered.

CALLIOPSIS-Showy and beautiful free flowering annuals; blooming all summer and excellent for cutting.

Golden Wave-Plant very bushy and compact, about 2 feet high, and covered from July to October with hundreds of beautiful golden blossoms, marked with dark brown in center. Pkt., 5c; $1 / 2$ oz., 15c; 1 oz., 25c.

California Sunbeams (Hardy)-Very large flowers; various shades of yellow; height $1 \mathrm{ft}$. Pkt., 10c.

Radiata-Dark brown, with twisted and fluted petals. (New.) Pkt., 10c.

Calendula (Pot Marigold)-Sow the seed early in the open ground and they will bloom profusely from June until frost.

Orange King-The grandest and best of all the Marigolds. Pkt., 5c; $x / 2$ oz., $15 \mathrm{c}$.

CANDYTUFT - Giant Hyacinth Flowered - The flower heads are of immense size, 6 inches long and about 3 inches across, resembling a Dutch Hyacinth. They are pure white. Pkt., 10c; $1 / 2$ oz., 20c.

Older sorts in mixed colors. Pkt., 5c; oz., 20c.

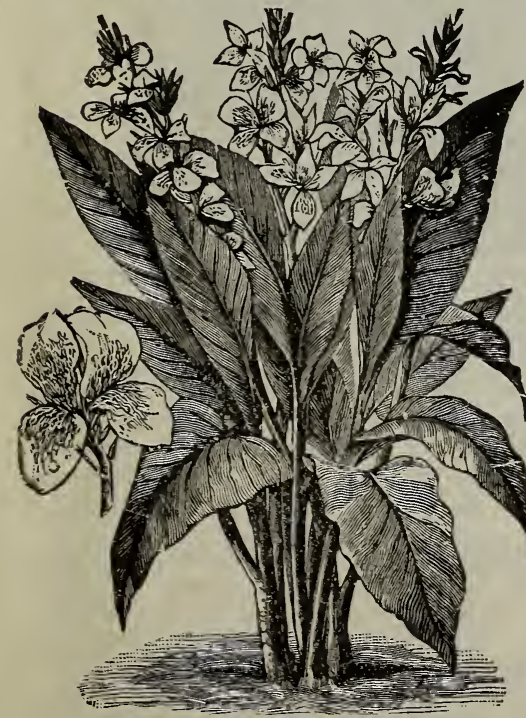

Candytuft Perennial Gibraltarica - Delicate blush white. Pkt., 10c.

CANTERBURY BELL (Campanula) - Cup and Saucer. A very striking and beautiful variety, and a most desirable and attractive addition to this class of old garden favorites; the flowers are nearly 4 inches in diameter, resembling a cup and saucer. Blue. Pkt., $5 \dot{c}$.

Medium Double Mixed. Pkt.,
CANNAS-“Giant Flowered Cozy Type"-Our seed has been saved from a collection comprising over 50 kinds. Soak the seed in hot water 12 to 24 hours before sowing. When young plants show two or more leaves, they should be transplanted. Pkt., 5c; oz., 20c. Gaint-Bright red. Pkt.. 5c: oz., 20c.

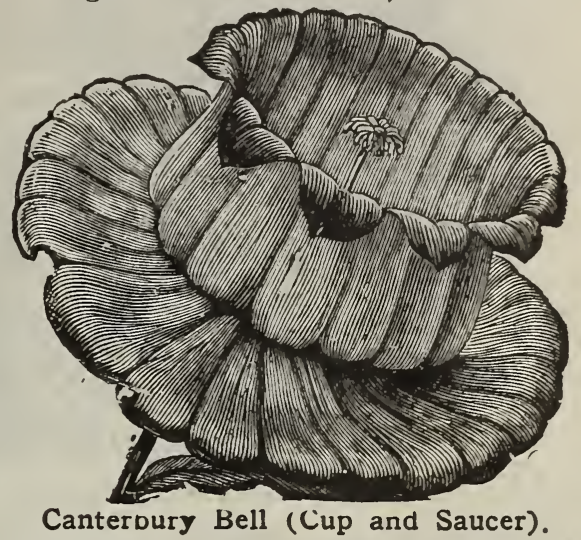

DWARF MARGARET CARNATION-A carnation that blooms the first year from seed. The plants are of dwarf, compact habit and flower most abundantly, through the whole year; 80 per cent of the flowers are very double, never burst, and embrace a great variety of color. Pkt., 10c; $1 / 8$ oz., 35c.

Grenadin-Dwarf, brilliant scarlet, very early flowering. Pkt., 10c. Large Double White, pkt., 10c; Large Double Pink, pkt., $15 \mathrm{c}$.

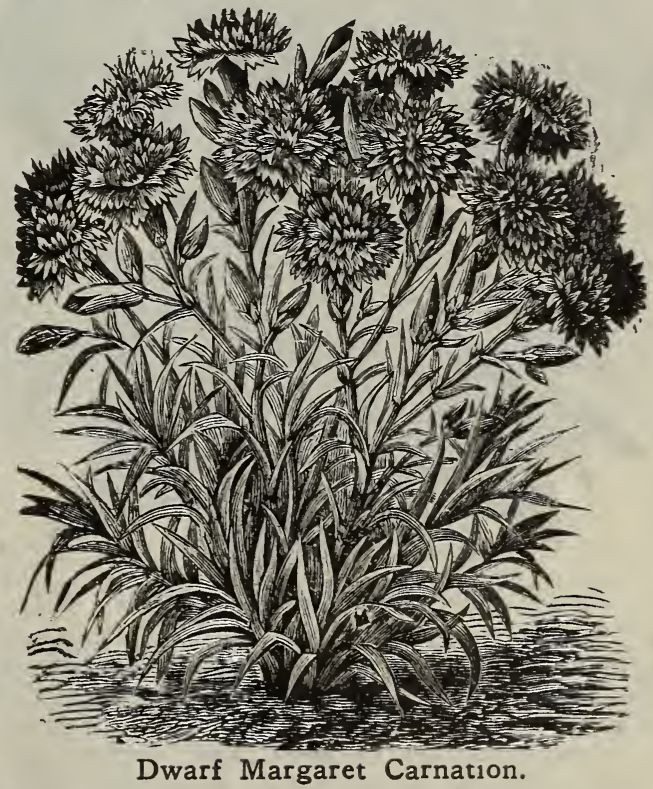

CENTAUREAS (Bachelor's Button)-Very free blooming, hardy annuals; also called Blue Bottle, etc. Pkt., 5c. Centaurea Candidissima, Pkt., 10c.

CENTAUREA (Marguerite)-This variety is entirely distinct from all other Centaureas. The plants grow about 18 inches high and are of the easiest culture. The large flowers are of the purest white.

CENTAUREA Imperialis (Giant Sweet Sultan)The bushes are from 3 to 4 feet high and are covered with large sweet-scented flowers. If cut when first opened will keep for a week in water. All colors mixed. Pkt., 5c. 


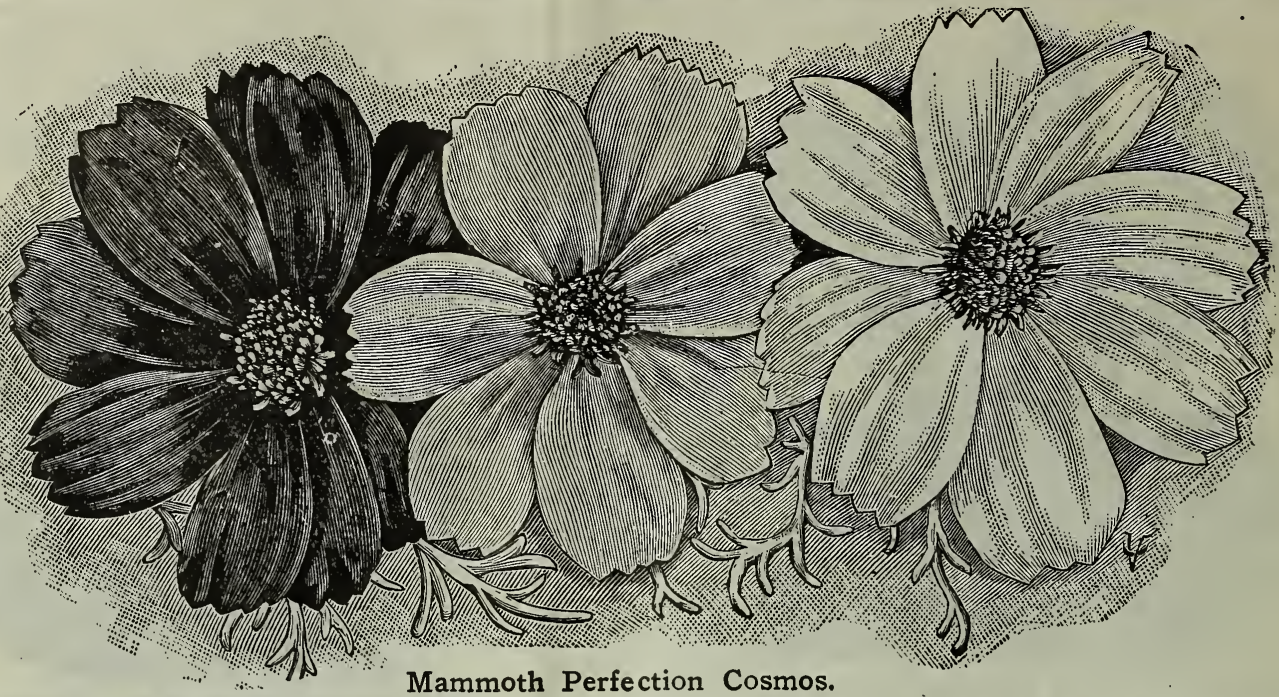

CHRYSANTHEMUM ANNUAL-No annual furnishes so many cut flowers as these, which bloom plentifully throughout the summer. Sow seed early in the spring in shallow drills and thin out or transplant, plants to be 10 inches apart. Double varieties mixed. Pkt., 5c; Oz., $15 \mathrm{c}$.

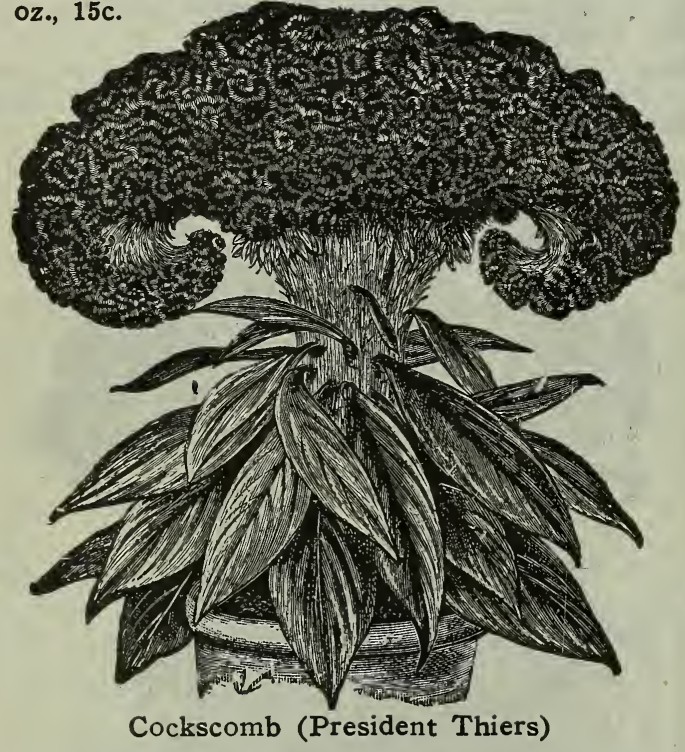

COCKSCOMB (Celosia)-Highly ornamental plants, producing crested heads, somewhat resembling a cock's comb; start in the house and transplant last of May.

COCKSCOMB (President Thiers)-One of the most dwarf of all cockscombs; bears large crimson combs; if planted alongside of rows of Golden Feverfew and Dusty Miller it will make one of the most brilliant strips of border; also a handsome pot plant. Pkt., 10c. Dwarf varieties, mixed, pkt., 5c.

COCKSCOMB (Ostrich Feather) - Ornamental, grown either in a pot or out of doors. Grows in pyramid form, about three feet high. Its scarlet flower sprays are feathered, or plume-shaped. Our mixture includes brightest colors in flowers and foliage. Pkt., 5c.

COSMOS-A very effective autumn flowering plant. Quite hardy and rapid growing, forming bushes often 4 to 6 feet high, and covered with large single Dahlialike flowers. Sow the seed early in spring thinly in drills, or two or three seeds may be planted in places where seed are to bloom; have the plants stand about two feet apart. If topped when half grown the plants will bloom much earlier, the check seeming to induce immediate flowering.

Mammoth Perfection-These are monstrous white flowers with flecked and pinked edges; the dark crimson flowers resemble large single Dahlias; the tinted varieties are charming, and others again are flushed with mauve and pink. The flowers measure from 3 to 4 inches across. White, pkt., $5 c$; pink, pkt., 5c; crimson, pkt., $5 c$; all colors, mixed, pkt., $5 c$; early flowering, mixed, pkt., $5 \mathrm{c}$; oz., $40 \mathrm{c}$.

\section{LADY LENOX COSMOS}

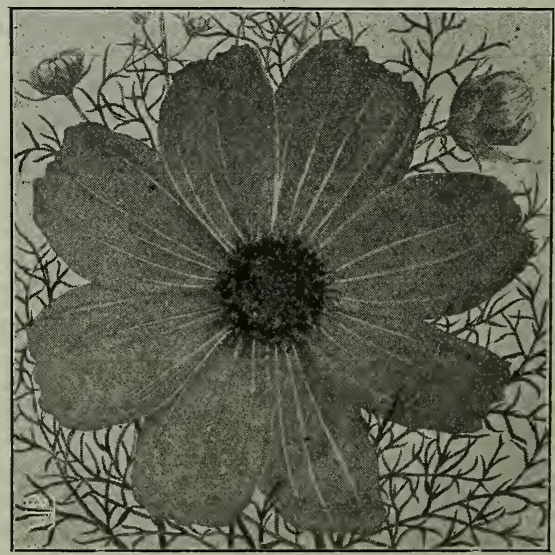

The New Gigantic Orchard Flowering Cosmos

An entirely new race of Cosmos of extraordinary size and beauty. Flowers 6 to 7 inches in diameter. Color a delightful shell pink, lighting up beautifully at night. Oval petals of splendid substance, forming a perfectly circular flower which, when cut, lasts an unusual length of time in water. Habit of plant strong and vigorous, growing 6 to 7 feet high. Flowers may be cut with any length of stem up to 5 feet. This is an entirely new Cosmos. Pkt., 20c.

WILD CUCUMBER-This is the quickest growing climber in our list. Grows wild, self-sown, in many parts of the West. It will grow 30 feet in one season. It is thickly dotted over with pretty white fragrant flowers, followed by an abundance of ornamental and prickly seed pods. For a trellis or pillar no annual vine is more chaste, and it will quickly cover an old tree or an unsightly building. Pkt., 5c; oz., 40c. 


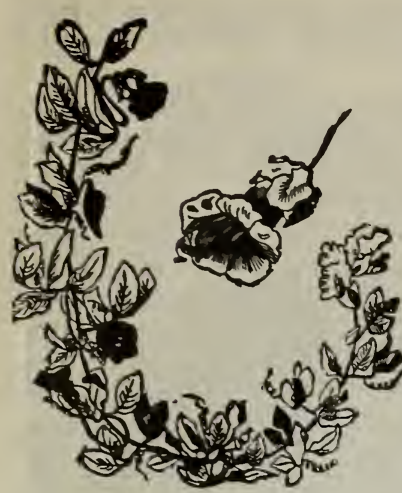

Cobaea Scandens.
COBAEA SCANDENS -A magnificent quickgrowing climber with beautiful foliage and large bell-shaped flowers. Plant the seed edgewise in moist earth and cover only slightly. Pkt., 5c.

CYPRESS VINE (Impomoea)-A most beautiful climber, with delicate dark green foliage and an abundance of bright starshaped rose, scarlet and white blossoms. Do not plant seed till the ground is thoroughly warmed. White, pink, crimson. Pkt., $5 c$; mixed, pkt., $5 \mathrm{c} ; 0 z ., 40 c$.

CYCLAMEN (Alpine Violet)-It is comparatively easy to cultivate Cyclamen from seed with much less expense and more satisfaction. They range in color from the brightest to the most delicate shades. Pkt., 10 seed, $20 \mathrm{c} ; 50$ seed, $65 \mathrm{c}$.

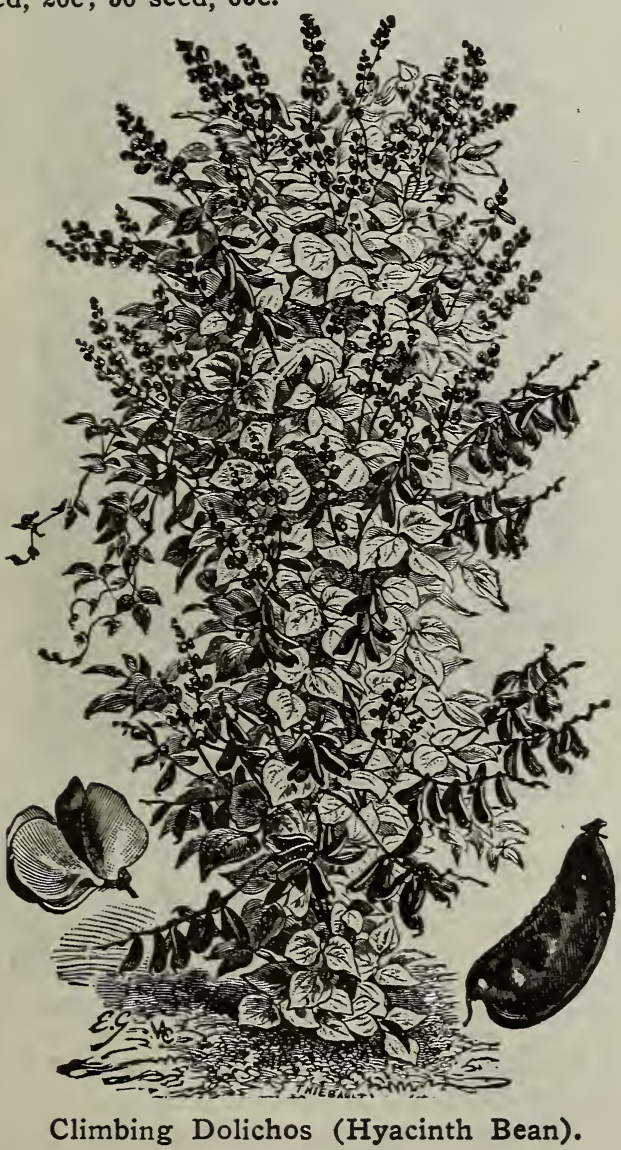

CLIMBING DOLICHOS (Hyacinth Bean)-(Princess Helen Daylight) - One of the prettiest climbers and certainly the most beautiful among the Dolichos or Hyacinth Beans. Of very rapid growth, the plant is indifferent to bad weather, and it will grow to a height of 15 feet by mid-summer. The flowers which appear in great numbers, are snow-white, sweet scented and are followed by cream colored pods, which hang on the plants until late in the fall. Pkt., 5c; oz., 35c; purple, pkt., 5c; oz., 20c.
DAISIES-Plants of double daisies will bloom the first summer and will continue to bloom for years if slightly protected during the winter.

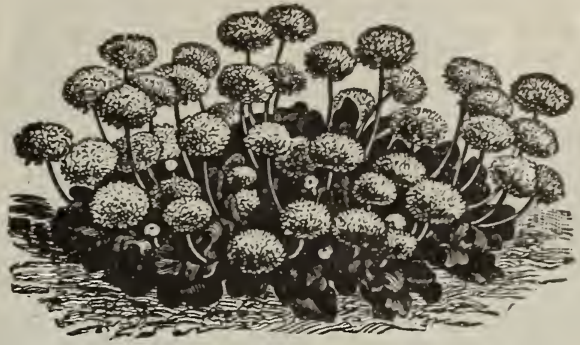

Double Daisy.

DOUBLE DAISIES (Bellis Perennis fl. pl.)-Very pretty flowers, desirable for borders; can be easily raised from seed sown in spring. Double white, pkt., $10 \mathrm{c}$; double mixed, pkt., $5 \mathrm{c}$.

SHASTA DAISY - A magnificent daisy or Marguerite, with pure white flowers with yellow centers. Borne on long, stiff stems; very valuable for cut flowers and decorative uses. The plants are perfectly hardy; blooms the first year from seed, but does not reach perfection until the second season. Seed, per pkt., 10c.

DAHLIAS-Grown from seed will flower the first year. Plant in the house in shallow boxes or pans; transplant as often as their growth requires; the seed germinates very easily. Double mixed, pkt., 10c.

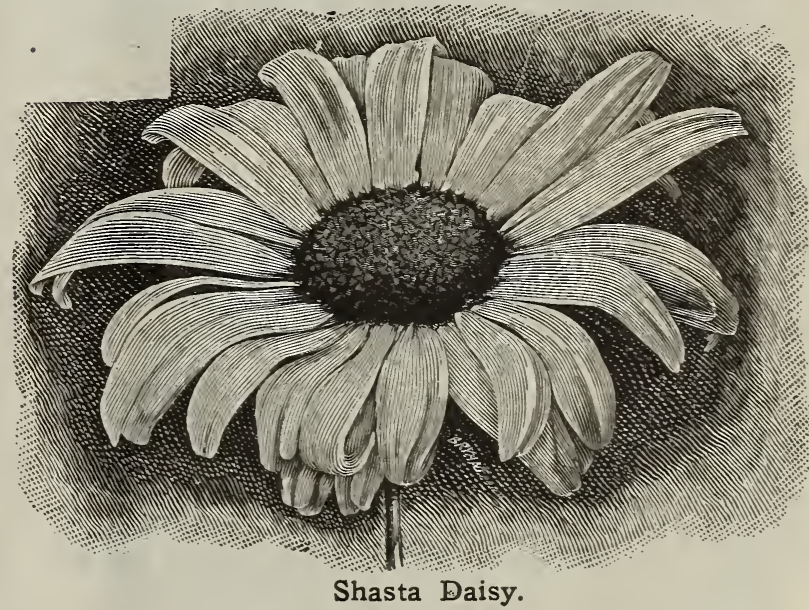

DELPHINUM (Larkspur)-One of the most showy hardy annuals in cultivation. The colors range in all shades of blue, white, pink, red and fawn. The shades are very seldom kept separate, as they are more effective when planted mixed.

Annual Varieties: Dwarf Rocket-Mixed, pkt., 5c; oz., 40c.

Tall Rocket-Mixed, per pkt., 5c; oz., 40c.

Perennial Varieties-Are taller than the annual varieties and need more space for growing. Blue, per pkt., $10 \mathrm{c}$.

ESCHOLTZIA, California Poppy-A genus of the poppy family, and fully as valuable as the common poppy for garden ornamentation, and as easily grown. Do not transplant. Height one foot.

THE GOLDEN WEST-Flowers have large overlapping petals, often delicately waved at the edges, showing beautiful and varied forms. Color an intense shining yellow with orange blotch at base of the petals. Pkt., 5c. 
FOXGLOVE (Digitalis)-Plants grow 3 to 4 feet and produce dense spikes of brilliantly colored flowers. A valuable flower in every perennial garden. Pkt., 5c.

FORGET-ME-NOT (Myosotis) - Beautiful little plants, with star-like flowers, blooming the first year if sown early. Pkt., 5c.

Alpestris-Blue. Pkt., 10c.

Alpestris Alba-White. Pkt., 10c.

Rosea-Pkt., 10c.

Victoria-Sky Blue. Pkt., 10c.

FOUR O'CLOCKS (Mirabilis or Marvel of Peru)Large growing shrub-like plants, with funnel-shaped flowers of many colors. Mixed, pkt., 5c; oz., 15c.

GERANIUMS-These grow readily from seed and produce blooming plants the first summer, and there is always the chance of securing something new and desirable in that way. Splendid mixed, pkt., $5 c$.

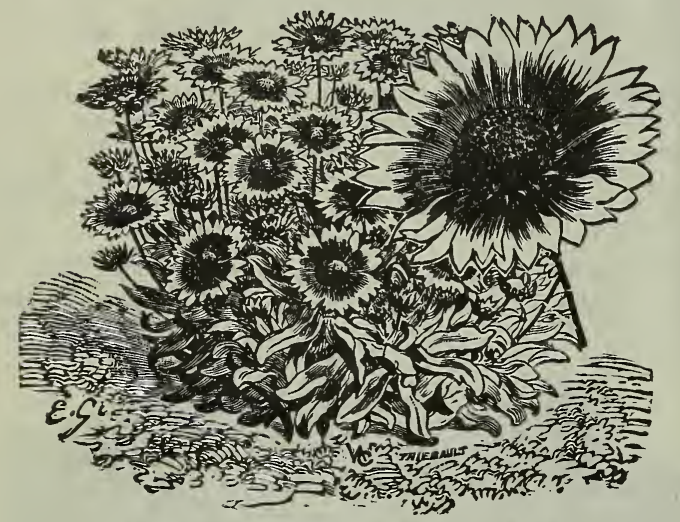

\section{Gaillardia Grandiflora Compacta.}

GAILLARDIA-Splendid bedding plants, remarkable for the profusion, size and brilliancy of their flowers, continuing in bloom during the summer and autumn.

Gaillardia Grandiflora Compacta-A beautiful new hardy flower. Compact growing varieties of the hardy perennial Gaillardias, forming round bushes of about 12 to 15 inches in height and bearing its long-stemmed blossoms perfectly upright. The colorings of the flowers are rich and varied. As the plants produce their flowers most profusely and in constant succession from June to autumn, this novelty with its improved habit will prove to be one of the most desirable of all hardy perennials, grown for cut flowers. Pkt., 10c, 2 for $15 \mathrm{c}$.

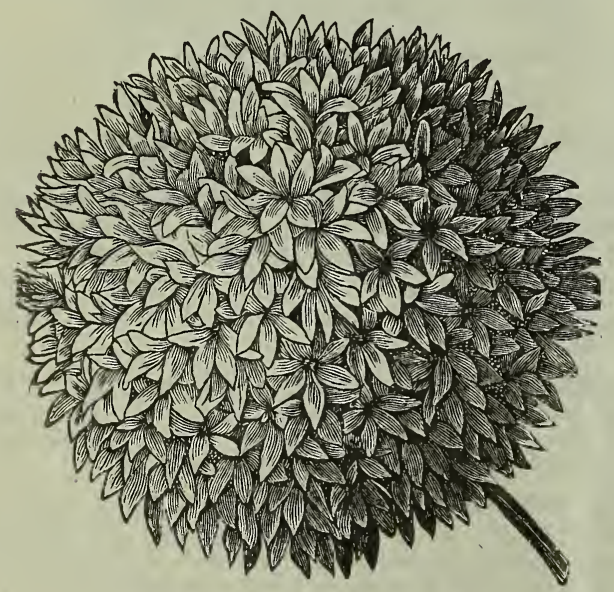

Gaillardia Picta Lorenziana.
Picta Lorenziana-A charming profuse double flowering strain of the hardy Gaillardia, beautifully mixed colors. Pkt., 5c.

ORNAMENTAL GOURDS-A class of rapidgrowing annual climbers, which attain a height of 20 feet in a season, and are most useful for covering old trellises, fences, stumps, verandas, etc.

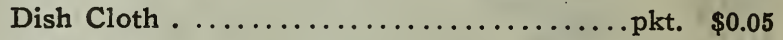

Nest Egg . . . . . . . . . .

Dipper........................... ${ }_{.05}^{.05}$

Sugar Trough $\ldots \ldots \ldots \ldots \ldots \ldots \ldots \ldots \ldots \ldots$. ${ }^{2}, \quad .05$

Apple Shaped . . . . . 05

Pear Shaped . ....................... ${ }_{05}$

Mixed . ..................... $\quad .05$

Mixed . ............................. $\quad .25$

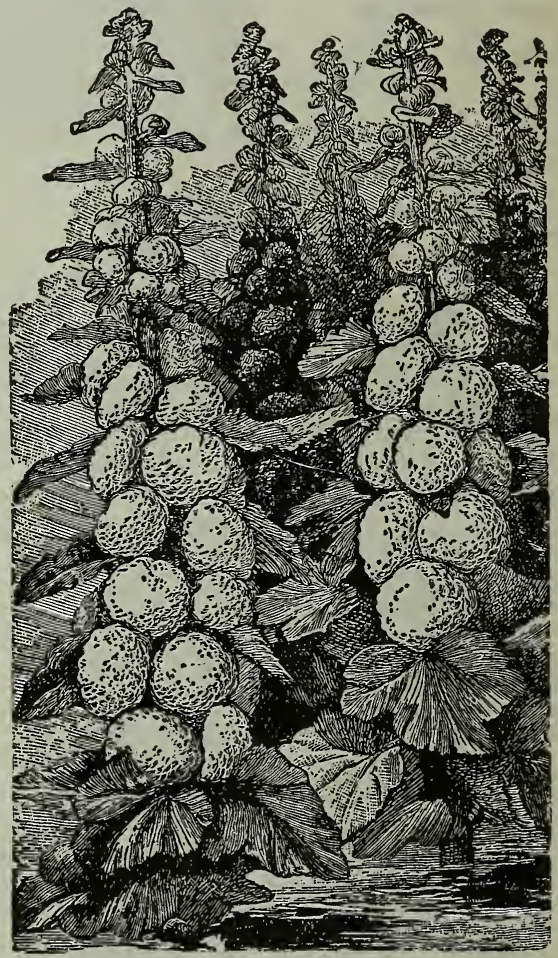

Hollyhock-Charter's.

THE HOLLYHOCK, in its present state of perfection, is very unlike its parents of olden times. It now ranks with the dahlia, aster, etc., being exceedingly rich and varied in color, and as double as a rose, and in the best, brightest and most charming colors. Charter's finest mixed, pkt., 10c; oz., $\$ 1.50$; Double White, pkt., 10c: oz., \$2.00; Double Pink, pkt., 10c; oz., \$2.00; Double Crimson, pkt., 10c; oz., \$2.00; Double Yellow, pkt., 10c; oz., $\$ 2.00$.

Mammoth Allegheny-Pkt., 60 seeds, 10c; 3 for 25c.

New Everblooming-Double and single mixed; blooms the first year from seed. Pkt., 10c. Single Mixed, pkt., 10c.

HELIOTROPE-A well-known old variety; its delightful perfume makes it a most desirable bouquet flower. Pkt., 10c.

JAPANESE HOP (Humulus Japonicus)-A splendid annual climber of rapid growth; withstands heat, drouth and insects; remains fresh until late in the fall. Pkt., 5c. 


\section{Chinese."Kudzu Vine}

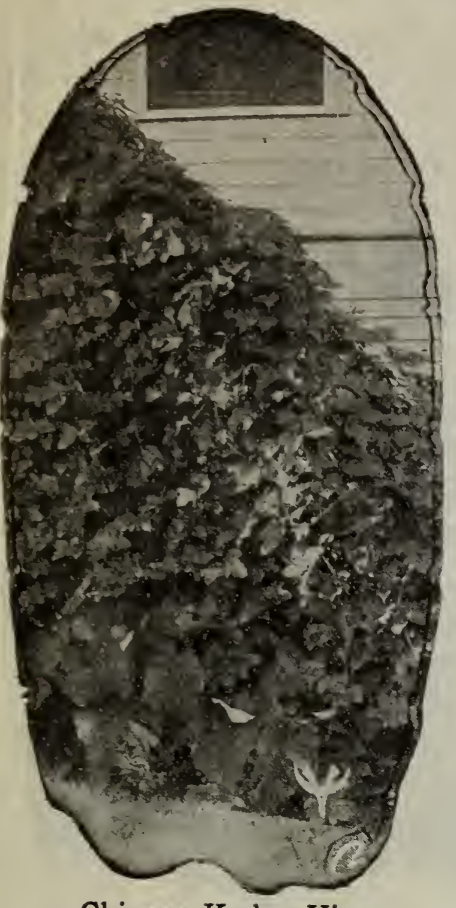

Chinese Kudzu Vine. Plst., 10c. (Jack and the Bean Stalk Vine) - A vine that will grow and flourish where nothing else will. Invaluable for covering fences, porches, old or dead trees. This vine is a native of China and is cultivated for its beauty and also for the edible value of its roots. Its large bright green leaves afford a dense shade. It is hardy and will last for many years. Will grow fifty feet if permitted, and has dense foliage clear to the ground. Per pkt., 10c; Oz., 75c.

KOCHIA SCO. PARIA (Summer Cypress)-Pretty ornamental plant with fine feathery foliage, very much like $\mathrm{Cy}-$ press Vine; light green turning to blood red in autumn.

LOBELIA-Exceedingly pretty and of value chiefly for hanging baskets and border work.

Crystal Palace Compacta-Deep blue, for bedding. Pkt., 10c.

Lobelia Cardinalis-Long spikes of rich cardinal flowers. Pkt., 10c.

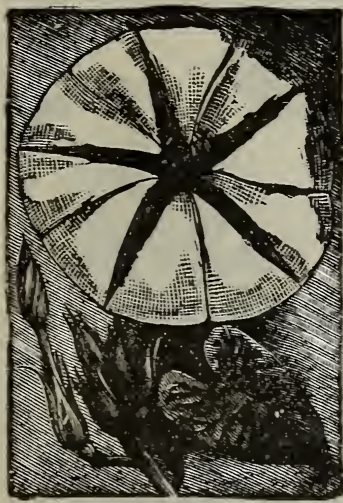

Moon Flower.
Lychins Haageana-Mixed, includes the choicest of flowers. Pkt., 10c.

Matricaria Golden BallSmall double yellow flowers, one foot. Pkt., 10c.

MOON FLOWER (White) -The most beautiful of annual climbers. In rich, warm ground the plants readily grow 25 feet high. The large flowers open at dusk, or earlier on cloudy days, at which time they are deliciously fragrant. Pkt., 10c; Moon Flower plants, $15 \mathrm{c}$ each; prepaid, $25 \mathrm{c}$.

\section{Giant Japanese Morning Glory}

Special Mixture-Nothing among flowers can furnish a more beautiful sight than a screen or trellis of these "Giant Japanese Morning Glories." Soak the seed in water for 24 hours before sowing. Best single fringed, mixed, pkt., 10c; oz., 25c.

Morning Glory (Convolvulus)-The best-known and most popular climber. Tall varieties, mixed, pkt., 5c; Oz., 10c; $1 / 4$ lb., $25 \mathrm{c}$.

\section{Marigolds}

The African and French Marigolds are old favorites; the former have uniformly large yellow or orange colored flowers and are well adapted for large beds; the latter are dwarf in growth, with beautifully striped flowers and better suited for bedding purposes; succeed best in light snil. with full exposure to the sun.

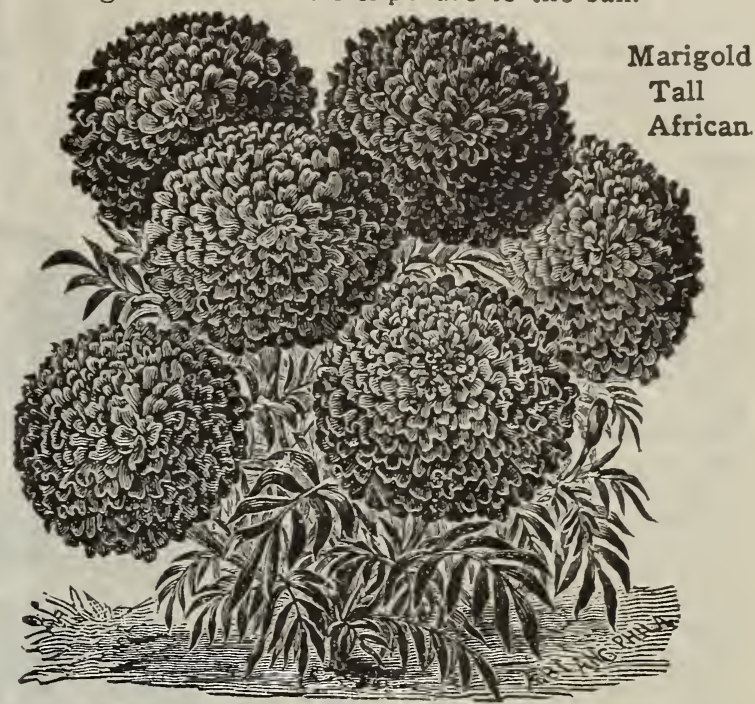

Double Tall African-Mixed, oz., 40c; pkt., 5c.

Double Dwarf French-Mixed, oz., 50c; plt., $5 \mathrm{c}$.

Legion of Honor-A beautiful single dwarf, bushy variety, bearing rich golden yellow flowers, marked with velvety brown.

MAURANDIA-Graceful climber for conservatory, parlor baskets, or out-door purposes; with rich purple, white and rose, tube-shaped flowers. Pkt., 10c.

\section{Mignonette}

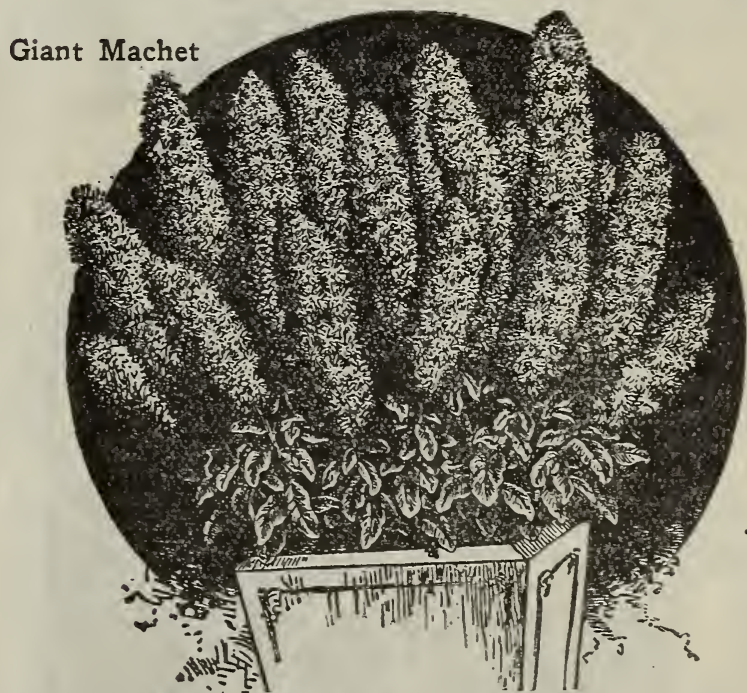

Giant Machet-There is no Mignonette which can equal this. Its flowers are larger in every way than those of other sorts, the spikes are very dense, its foliage distinct, while its odor is strong and most delicious. Pkt., 10c; $1 / 2$ oz., $40 \mathrm{c}$.

Reseda Odorata (Sweet Scented)-A well-known annual, producing dense, semi-globular heads of exceedingly fragrant flowers. Pkt., 5c; oz., 15c.

Ameliorata-Very sweet scented. Plst., 5c; oz., 15c.

Crimson Queen-Pkt., 5c; $1 / 2$ oz., $40 \mathrm{c}$.

Mimulus Cuprens-Mixed hardy annual, musk scent; nice for border. Pkt., 10c. 


\section{NASTURTIUMS-Tall Varieties}

Besides their ordinary use in the garden for trailing over stone walls, fences and trellises, they are very pretty grown in pots, hanging baskets and vases for winter plants. 20c.

Crown Prince of Prussia-Blood red. Pkt., 5c; oz.,
Queen Victoria-Rich scarlet. Pkt., 5c; oz., 20c.

Spitfire-Brilliant scarlet; very effective. Pkt., 5c; oz., 15c.

Ruby King-Dark red. Pkt., 5c; oz., 20c.

Dark Crimson-Pkt., 5c; oz., 20c.

Chamelon-Mixed. Pkt., 5c; oz., 15c.

King of the Blacks-Crimson maroon, with dark markings. Pkt., 5c; Oz., 20c.

Black Prince-Velvety black purplish-crimson, dark foliage. Pkt., 5c; oz., 20c.

Lucifer-Dark scarlet. Pkt., 5c; oz., $20 \mathrm{c}$.

Primrose-Cream with brown spots. Pkt., 5c; Oz., 20c.

Pearl White-Pkt., 5c; 0z., 15c.

Extra Fine Tall Mixed-A very choice mixture of the best named sorts, including some of "Lobb's Nasturtiums" and the beautiful "New Hybrids." Pkt., 5c; Oz., 15c; I/4 lb., 30c; $1 \mathrm{lb} ., \$ 1.00$.

Hybrids of Madam Gunther's-This race is distinguished by its dark foliage and richness of color. They make a strong growth, climbing from 6 to 10 feet high, and are covered with large flowers of the most brilliant shades. They are remarkable for their wide range in self colors, as well as striped and blotched. Pkt., 5c; oz., 10c; $1 / 4 \mathrm{lb}$., $30 \mathrm{c}$.

Tropaeolum Lobbranum - Mixed, each: Pkt., 5c; 0z., 10c; $1 / 4$ lb., 30c; 1b., $\$ 1.00$.

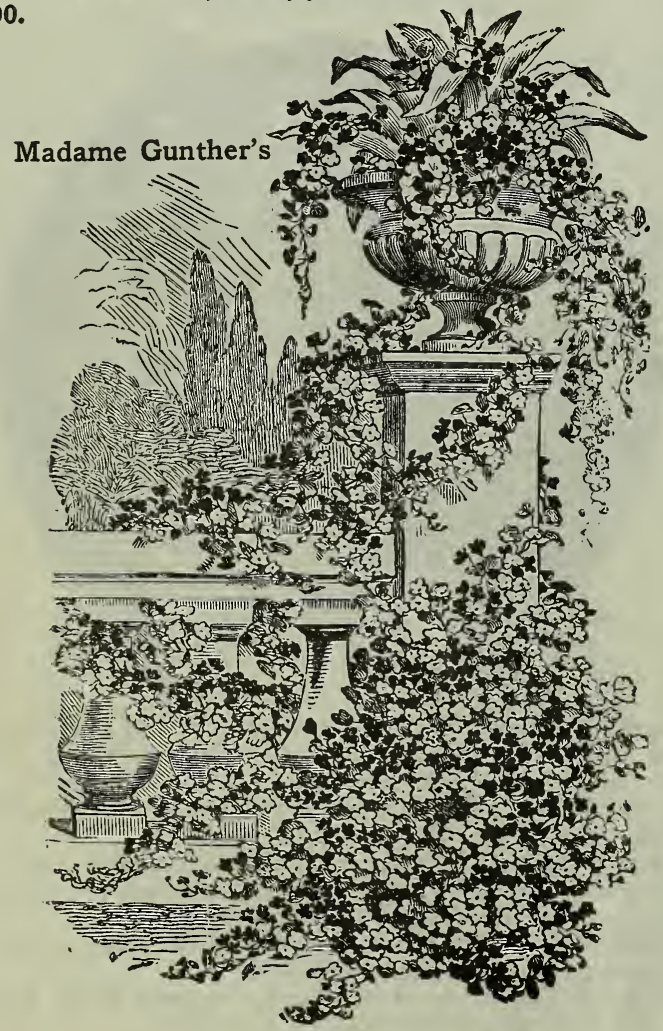

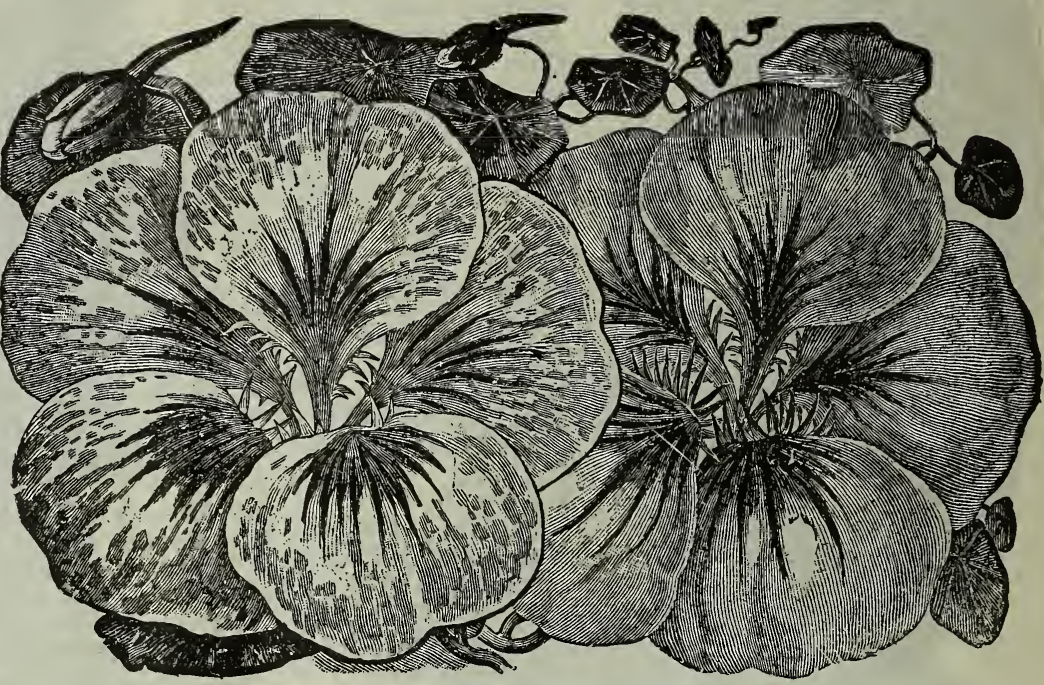

Dunnett's Orange-Pure orange, no markings, Pkt., 5c; oz., 15c.

Golden Queen-Golden yellow. Pkt., 5c; oz., 20c. $15 \mathrm{c}$.

Heinemanni-Silky bronze chocolate. Pkt., 5c; az.,

\section{Dwarf Varieties}

Aurora - D e e p chrome yellow, the two lower petals blotched and varied yer carmine. Pkt., 5c;

oz., 20c. Dark maroon, bluish $\%$. green foliage. Pkt., 5c; oz., 25c. Prince Henry-
Flowers beautiful golden yellow, spotted scarlet; deep Pkt., 5c; oz., 20c.

Empress of India - Deep crimson, with dark foliage.

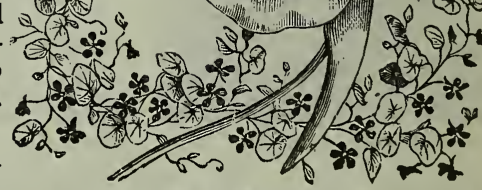

Lobb's Nasturtiums.
Pkt., 5c; Oz., 20c.

Golden King-Rich golden yellow. Pkt., 5c; oz., 15c.

King of Tom Thumbs-Dark scarlet, dark leaves. Pkt., 5c; oz., 20c.

Pearl-Creamy white. Pkt., 5c; oz., 15c.

Ruby King-Rich crimson. Pkt., 5c; oz., 20c.

Extra Fine Dwarf Mixed-Pkt., 5c; oz., 15c; 1/4 lb., $35 \mathrm{c} ; 1$ lb., $\$ 1.25$.

We are careful in the selection of the Seeds we send our customers, hence the secret of our success. 


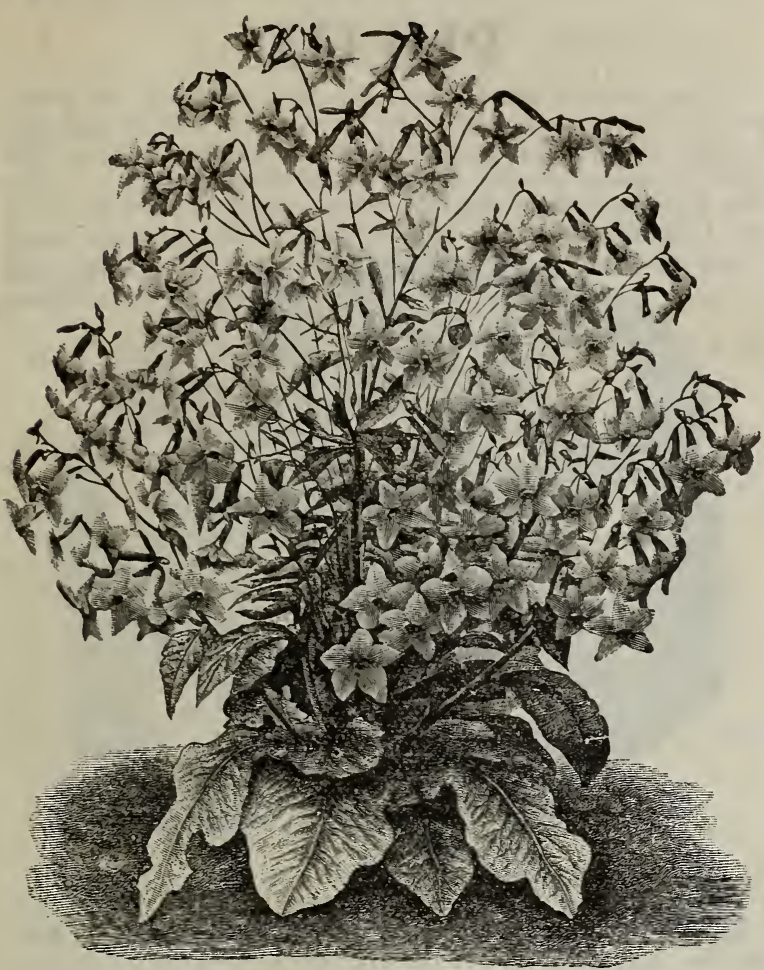

Nicotiana Sanderae.

NICOTIANA AFFINIS (Sweet Scented Tobacco Plant)-A handsome genus of garden plants of the tobacco family, noted for the freedom and fragrance of their bloom. Half hardy annuals, 3 feet high. Flowers white, salver shaped, having long tubular corollas, and are of exquisite fragrance. Deserves a place in every garden. Pkt., 5c.

NICOTIANA SANDERAE-Laden with handsome carmine blossoms from base to summit, which are produced on a single plant, making a beautiful plant for garden, bed or shrubbery border; a hardy annual, with dark foliage. Pkt., 10c.

\section{PANSIES}

May be sown either in early spring or fall. When sown in the fall, make fine blooming plants for early spring; if sown in spring will bloom through July and August. Pansies will bloom through the entire summer, but produce finest flowers in spring and fall when the weather is cool. They do better in a cool moist location.

Harnden's. many colors, in good mixture, pkt., $5 \mathrm{c}$; $1 / 4$ oz., 20c.

Curled Giant Pansy "Masterpiece"-This strain comes nearer to "Double Pansy" than anything ever introduced under that name. In reality the number of petals is the same as of other pansy flowers, but they are crimpled and curled in such a fashion that flowers appear double. The flowers are of enormous size, often 3 inches across, and the color, variations and combinations are odd and striking. The plants are unusually strong and healthy, holding their large, handsome flowers well up above the foliage. Pkt., $15 \mathrm{c} ; 1 / 8$ oz., $75 \mathrm{c} ; 1 / 2$ oz., \$2.00; oz., \$3.50.
Harnden's Superb Mixed-The richest and choicest mixture offered, producing the finest colors and largest flowers. The finest pansy we have ever offered our customers. Pkt., 25c; $1 / 8$ oz., $\$ 1.25 ; 1 / 2$ oz., $\$ 4.00 ;$ oz., $\$ 7.50$.

Imperial Giant German Mixed-Pkt., 25c; $1 / 2$ oz., $\$ 2.50$; oz., $\$ 5.00$.

Best Giant French Mixed-Pkt., 15c; I/2 oz., \$2.00; oz., $\$ 3.50$.

Harnden's Park Bedding Varieties comprise all the best colors and strains of pansies we have tested for the last fifteen years, and can recommend each and every one. The plants are of even growth; the flowers are large and well above the foliage; a fine strain for bedding purposes. Pkt., 10c; $1 / 2$ oz., $\$ 1.50 ; 0 z ., \$ 2.50$.

Emperor William-Ultramine blue. Pkt., 10c; oz., \$2.

Red Riding Hood-Bright shade of red. Pkt., 10c; oz., \$2.

Snow Queen-Pure satiny white. Pkt., 10c; oz., \$2.

Golden Queen-Pure yellow. Pkt., 10c; oz., \$2.

King of the Blacks-Pkt., 10c; oz., \$2.

Bronze-Golden bronze. Pkt., 10c; oz., \$2.

Meteor-Bright yellow and brown blotched. Pkt., $10 \mathrm{c} ; \mathrm{oz}$., $\$ 2$.

Striped and Fancy-Pkt., 10c; oz., \$2.00.

Lord Beaconfield-Deep pure violet. Pkt., 10c; oz., \$2.

Emperor Frederic-Dark purple with golden orange border. Pkt., 10c; oz., \$2.00.

Peacock-Rainbow shades. Pkt., 10c; oz., \$2.

Light Blue-Beautiful self colored. Pkt., 10c; oz., \$2.

Purple-White edge. Pkt., 10c; oz., \$2.

Purple Mantle-Firey purple. Pkt., 10c; oz., \$2.

Victoria-Splendid claret red. Pkt., 10c; oz., \$2.

Many colors in splendid mixture. Pkt., $10 \mathrm{c} ; 1 / 8 \mathrm{oz}$., 30c; oz., \$2.

Giant Trimardeau-The largest flowering of all giant pansies. Contains a very fine assortment of colors. Pkt., $15 \mathrm{c}$; oz., $\$ 3.50$.

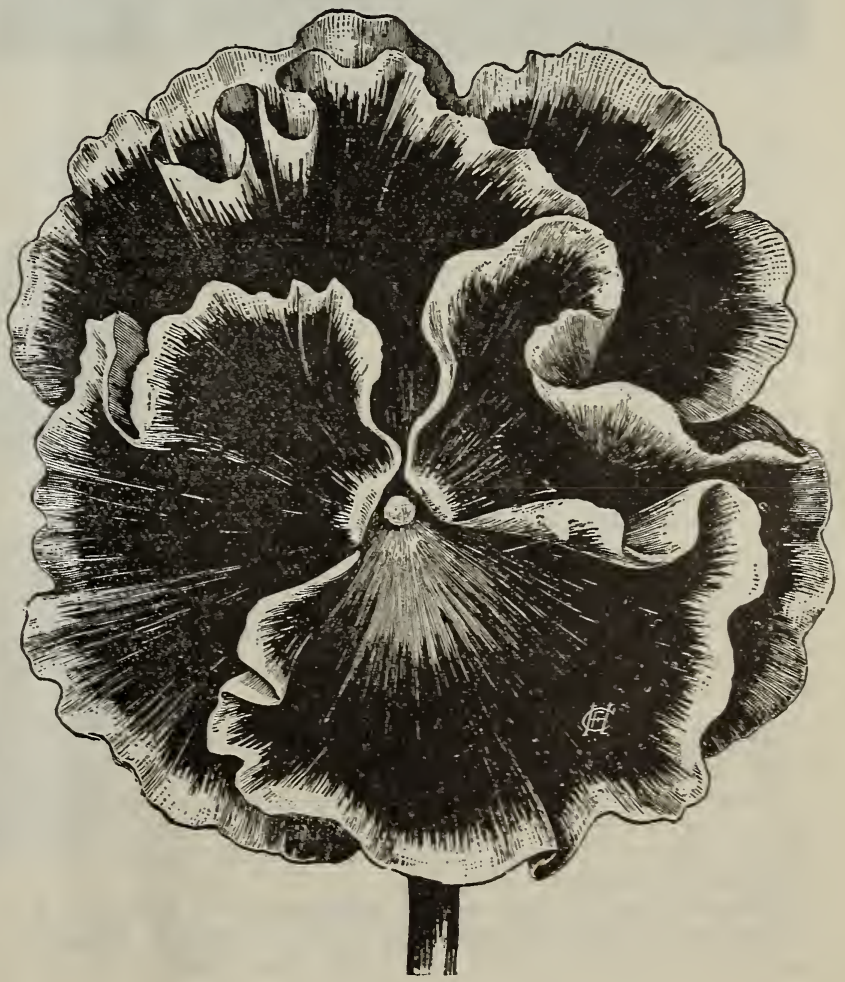




\section{PETUNIA}

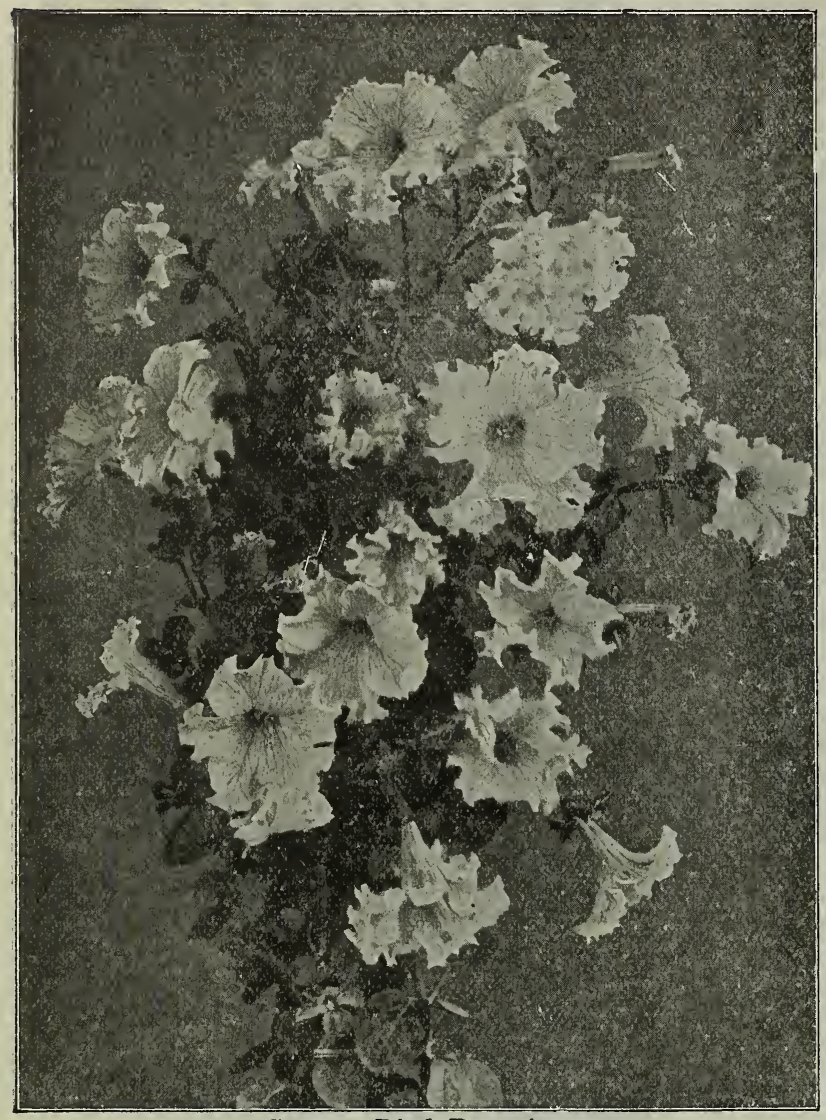

Canary Bird Petunia

Beautiful free blooming plants of easy cultivation. They commence flowering early and continue a mass of bloom throughout the season. Sow the seed any time in the spring in shallow drills or broadcast, and when well started thin out or transplant to stand 1 foot apart each way. The seed of the Double Giant Flowered varieties is so expensive that it would be advisable to sow it in boxes in March or April and transplant later.

Canary Bird Petunia-Attains a height of about 14 inches and has a compact habit of growth. Flowers of medium size, with finely fringed and curled borders and of a distinct yellow color which deepens in the throat. Some flowers have a slight green tinge, but the yellow color predominates. Per pkt., 25c.

Choice Mixed-A very fine strain, including many of the large flowering varieties. Pkt., 10c; $1 / 8$ oz., 25c.

Large Flowering-They are unexcelled in size, substance and brilliancy of color. Pkt., 20c.

Admiration-Beautiful dark blue with white stripes and spots.

Alba-Pure white.

Atropurpurea-Deep purple.

Dark Blood Red-With white throat.

Single Large Flowering Fringed-A choice selection; the flowers are of very large size and beautiful shape; deep throated and of varied and brilliant colors and beautifully fringed. Pkt., 25c.

Double Large Flowering Fringed-Will produce a large percentage of double flowers; of largest fringed varieties in bright colors and tints. Pkt., 25c.

\section{PHLOX}

There is no annual which can be compared for beauty and brilliance of colors to the Phlox; their long duration in bloom, combined with their almost unequaled richness of color, render them of invaluable service. Sow the seed thinly in shallow rows and thin out or transplant the plants when 2 inches high about 6 inches apart.

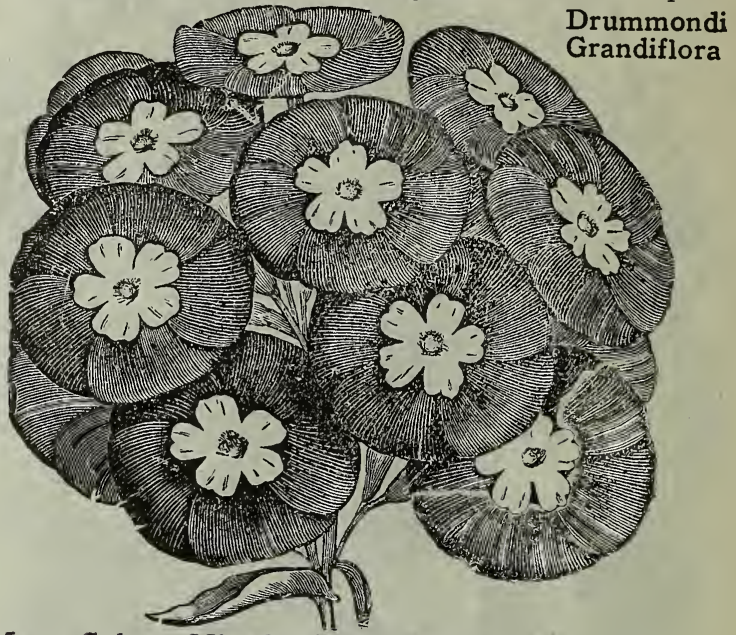

Many Colors, Mixed, $1 / 4$ oz., 15c; pkt., $5 c$.

Large Flowering Varieties, Mixed, $1 / 4$ oz., 25c; pkt., 10 cts.

Star of Quedlinburg-A very striking variety. The growth is dwarf and the habit very compact; the flowers are very distinct and of regular star-like appearance, thus producing a most brilliant effect. Many colors, mixed, pkt., 10c.

DWARF PHLOX-A lovely strain, the plants growing very symmetrical in neat little bushes about 6 to 8 inches high and covered with bright flowers during the whole summer and fall; much superior to the other phloxes for ribbon bedding or borders. Mixed, pkt, 10c.

Snowball-Flowers pure white. Pkt., 10c.

Fireball-Glowing brilliant scarlet. Pkt., 10c.

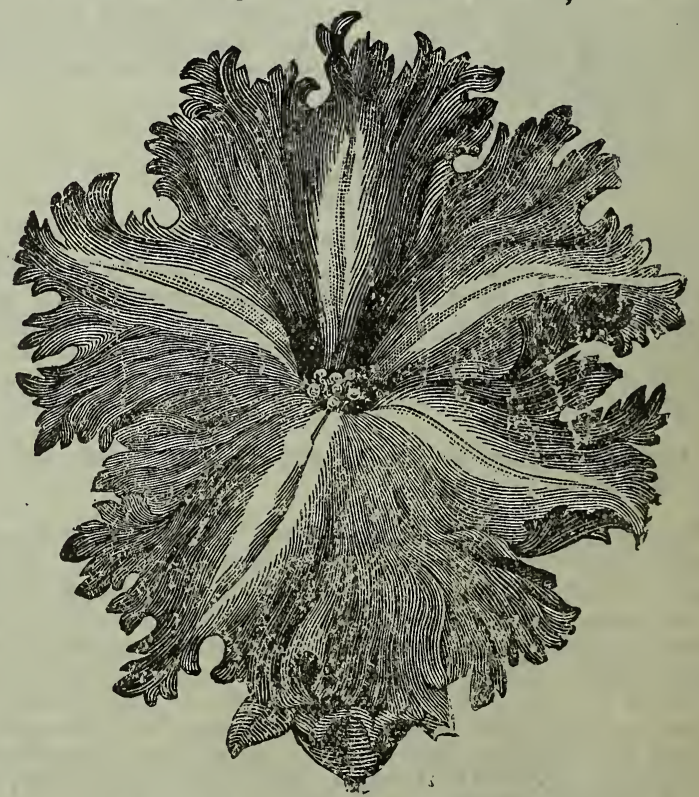

Single Large Flowering Fringed Petunia 


\section{PINKS-Dianthus}

Double Chinese-The flowers are all double and very showy. Mixed, per pkt., $5 \mathrm{c}$.

Heddewigi (Japan Pink)-Beautiful double flowers of the brightest colors. Handsomely fringed. Borne on long stiff stems. Per pkt., 5c.

Mourning Pink-The most striking of all pinks; rich velvety crimson, margined with pure white. Pkt., 5c.

PLATYCODON GRANDIFLORA (Japanese Bell Flower)-Blooms constantly from June until late in September; flowers large, bell shaped, white and blue; perfectly hardy; three feet high.

Blue, pkt., 10c. White, pkt., 10c. Mariesi, dark blue, pkt., 10c.

\section{PORTULACA}

There is scarcely any flower in cultivation that makes such a dazzling display of beauty as a bed of many-hued, brilliant-colored Portulacas. They thrive best in a rather rich, light loam or sandy soil, and an exposed sunny situation.

Single mixed, pkt., $5 c$; $1 / 2$ oz., $25 c$.

Double mixed, a very fine strain producing a great many double flowers. Pkt., $10 c ; 1 / 8$ oz., $75 c$.

PYRETHRUM (Feverfew)-Very useful and universally admired bedding plants, deserving a place in every garden.

AUREUM (Golden Feather)-Beautiful gold-leaved bedding plant; used largely for ribbon bedding. Pkt., 5c.

\section{POPPIES}

These old-fashioned flowers are at present, like the well-known Dahlias, regaining their old-time popularity. This is not strange when we consider how little time is required for their culture. Their brilliant color and wonderful variety make a very effective display in the garden or for cut flowers.

Shirley, Silk or Ghost Poppy-The Shirley Poppy is not new. The plants grow about $2 \frac{1}{2}$ feet high, with large, finely shaped flowers, being generally single or semi-double, and running through a great variety of colors, especially strong in shades of terra-cotta and combinations of this with pink. Pkt., $5 c$.

Tulip Poppy-Produces large, splendid, bright scarlet flowers, strikingly beautiful, reminding one of a dazzling bed of tulips; 14 inches high. Pkt., 5c.

Carnation Flowered-Splendid double fringed flowers of various colors. I/4 oz., $15 \mathrm{c}$; pkt., $5 \mathrm{c}$.

Feathered, double mixed, per pkt., $10 \mathrm{c}$.

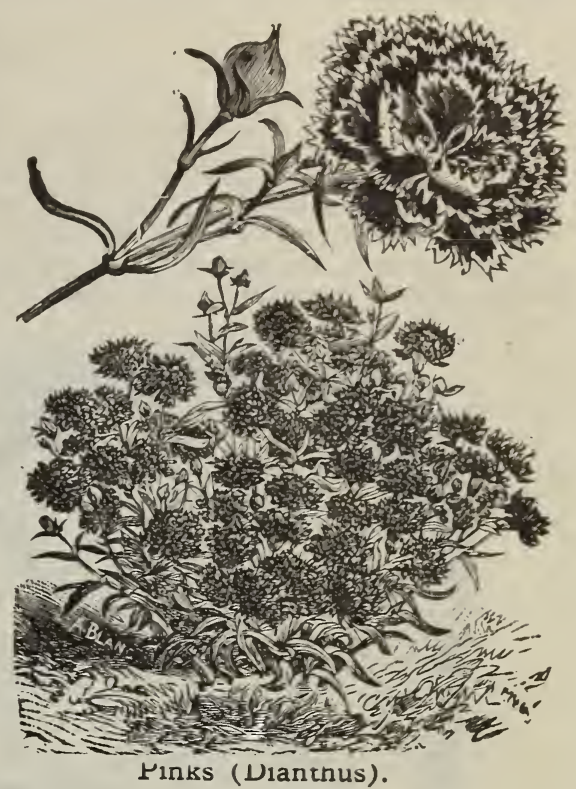

Oriental-Enormous flowers of deep flashing scarlet; perfectly hardy; 3 feet. Pkt., 10c.

Iceland Poppy-Hardy perennial; blooming the first year from seed; of graceful, neat habit, with bright green, fern-like foliage. The colors range from purest white to the deepest orange scarlet; one foot high; orange, white and yellow. Per pkt., 10c.

\section{RICINUS-Castor Bean}

A very showy plant. Can be used in various ways; planted thickly, it forms a handsome hedge or screen; may be used with Cannas to a very good effect, lends a tropical appearance to the garden.

Cambodgensis-Large, palm-like leaves of brilliant bronzy red; stalks nearly black. Pkt., 5c; r/2 oz., 20c.

New Zanzibar-A new and distinct class, which surpass in size and beauty all the varieties heretofore known. The plant grows from 10 to 15 feet high, and the leaves measure about 30 inches across. Mixed va. rieties, $1 / 2$ oz., $20 \mathrm{c}$; pkt., $5 \mathrm{c}$.

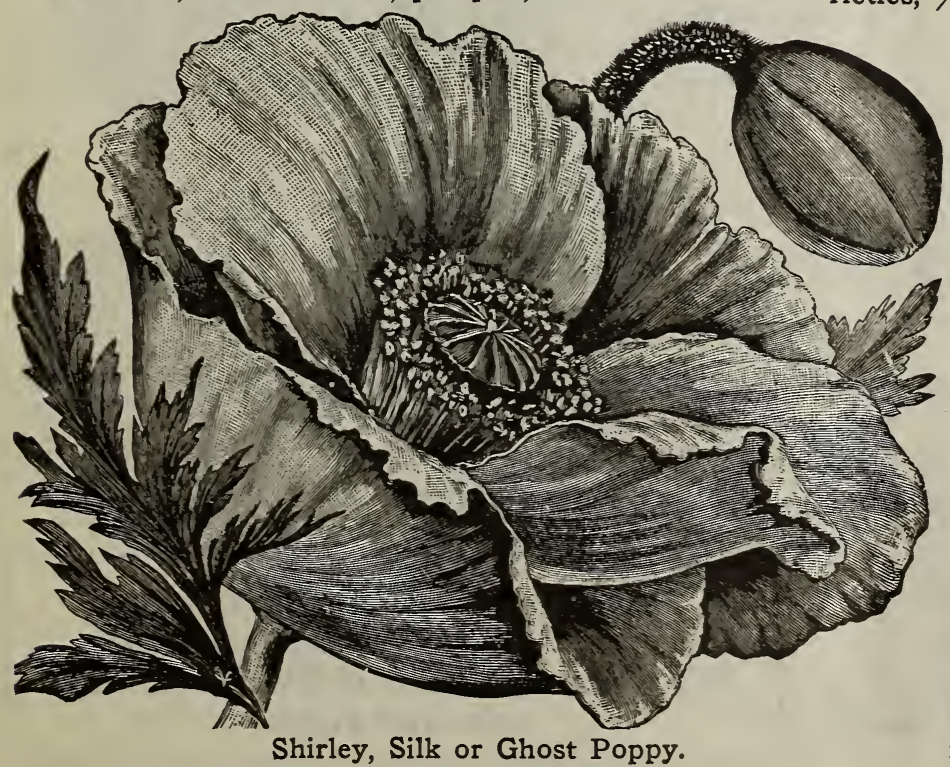

\section{SALPIGLOSSIS}

New Emperor-Thrives in any good garden soil, and in almost any situation. This strain is a great improvement over the older type in its increased size of flowers, their improved shape and large variety of colors. Pkt., 5c.

\section{SCABIOSA}

Mourning Bride-One of the handsomest summer plants; producing in great profusion very double flowers in a variety of shades and colors; a splendid flower for table bouquets; 1 to 2 feet. Mixed sorts, pkt., 5 c.

\section{SWEET WILLIAM}

\section{Dianthus Barbatus}

The seed can be planted very early in the spring and will blossom the following summer; or sown in August, will make blooming plants for spring. Single mixed, pkt., 5c; double mixed, pkt., 10c. 


\section{SWEET PEAS}

Culture-The seed should be sown as early as the ground can be worked in the spring, to enable the vines to get a good strong growth before the warm weather comes. They are usually grown in double rows with a wire trellis or a row of brush between. Make a trench six inches deep; in this sow the seed plentifully two inches deep. As soon as the plants begin to show

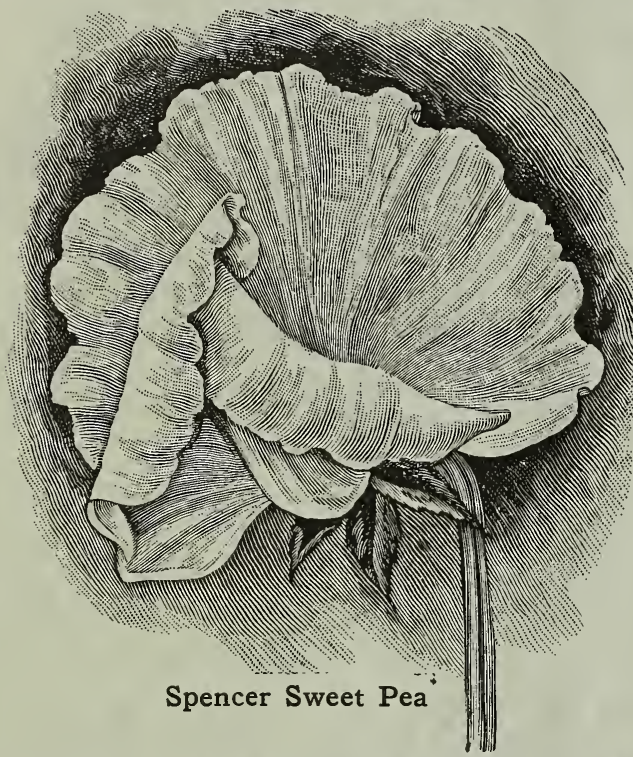

through, fill up the trench with soil. This will secure a deep planting without the bad effects of deep covering of the seed at first. As the flowers come in full bloom or fade, they should be cut off, for, if the pods are allowed to form they will stop blooming. Remember1st, Sweet Peas do best in rich, moist soil; 2nd, do not loosen soil around the plants; $3 \mathrm{rd}$, plant seed in a warm sunny spot. A liberal use of bone fertilizer worked into the soil will give excellent results.

Prices, unless otherwise noted: Pkt., 5c; oz., 10c; $1 / 4$ 1b., 25c; 1b., 60c.

\section{WHITE.}

Dorothy Eckford-Pure white, large flower.

Shasta-Large, ivory white, fluted wings.

Mont Blanc-Early flowering; pure white.

Emily Henderson-Clear white; wings broad; early.

Blanch Burpee-Large, pure white.

White Spencer-Produce in great profusion; enormous size; pure white. Pkt., 5c; oz., 10c; r/4 lb., 30c; lb., $\$ 1.00$.

\section{DEEP AND LIGHT PINK.}

Agnes Eckford-Soft bright pink; perfect form; giant size.

Apple Blossom-Crimson pink, shaded white; wings white shaded pink.

Blanche Ferry-Medium size, fine form, bright pink color, wings large.

Earliest of All-Bright rose, white wings.

Katherine Tracy-Soft rosy pink, light edges, large flowers.

Lovely-Deep pink, shaded to light pink.

Prima Donna-Large fine form. Blush pink.

Florence Morse-Spencer-Delicate blush, with pink margin. Excellent for cutting. Pkt., 10c; oz., 20c; $1 / 4$ lb., 50c; 1 lb., $\$ 1.75$.

\section{ORANGE PINK.}

Aurora-Beautifully flaked with bright orange salmon.

Bolton's Pink-Rich pink, profused with salmon.

Gorgeous-Bright orange pink, shaded rosy lilac.

Janet Scott-Light pink and buff.

Lady Mary Currie-Deep orange pink; delicately shaded rosy lilac.

Helen Lewis or Orange Countess-Spencer-Rich crimson orange; size large; fine Spencer form. Pkt., 5c; oz., 10c; $1 / 4$ lb., 30c; lb., $\$ 1.00$.

\section{LAVENDER AND LIGHT BLUE.}

Countess of Radnor-Distinct beautiful shade of lavender.

Countess Cadogan-Little darker than navy blue.

Dorothy Tennant-Rose purple.

Flora Norton-Bright sky blue.

Lottie Eckford-White shaded with lilac.

Lady Grisel Hamilton-Large flower, distinct shade of lavender.

Helen Pierce Spencer-Marble blue on white ground. Pkt., 5c; oz., 10c; T/4 lb., 30c; lb., $\$ 1.00$.

Phenomenal-Lilac with white edge. Pkt., 5c; oz., $10 c ; x / 4$ lb., 30c; lb., $\$ 1.00$.

\section{DARK BLUE AND PURPLE.}

Duke of Sutherland-Deep claret, standard; wings bright indigo blue.

Duke of Westminster-Almost a clear purple.

Lord Nelson-Deep navy blue.

Mrs. Geo. Higginson, Jr.-Azure blue.

Navy Blue-Blue, rich violet purple.

\section{BRIGHT RED AND ROSE.}

America-Blood red, striped white.

Mrs. Dugdale-Primrose, overlaid with bright red.

King Edward VII-Dark bright crimson, large flowers.

Prince of Wales-Shell shaped, clear rose crimson.

Salopian-Deep rich red variety, shell shape form.

Geo. Herbert-Spencer-Bright rose carmine; large. open and wavy form of the Countess Spencer. Pkt., 5c; oz., 15c; r/4 lb., 35c; lb., \$1.25.

\section{DARK RED AND MAROON.}

Black Knight-Dark maroon.

Black Michael-Beautiful dark plum color; large.

Mrs. Walter Wright-Rose purple, changing to blue when full matured.

Duke of Clarence-Dark claret.

\section{YELLOW AND PRIMROSE.}

Hon. Mrs. E. Kenyon-Fine large clear primrose.

Primrose-Spencer-Wings and standard crinkled and waved; pronounced primrose color. Pkt., 5c; oz., 10c; $\mathrm{x} / 4 \mathrm{lb}$., 30c; lb., $\$ 1.00$.

\section{Our Poultry Supply Department Is Up-to-Date We Carry all Kinds of Remedies, Sup- plies and Foods}




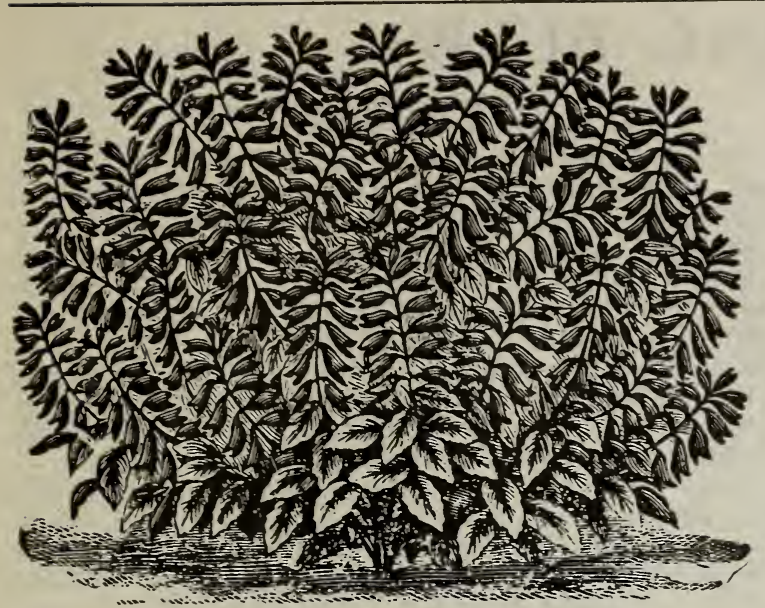

New Scarlet Sage-"Clara Bedman."

\section{VERBENAS}

Plants grown from the seed are not only cheaper, but are strong and vigorous in growth, with rich, dark foliage, and continue in bloom until cut off by heavy frosts. Sow seed early in cold frame boxes in light sandy soil, in a sunny window, or it may be sown thinly in shallow drills in open ground. When the young plants are well started, they should be thinned or transplanted to stand twelve inches apart in the row.

Hybrida-Fine mixed; very good strain. Pkt., 5c; $1 / 4$ oz., 30c.

New Mammoth Verbenas-Of unusual size, embracing a wide range of colors. Pkt., 10c; $1 / 8$ oz., 40c.

Mammoth-Large, pure white. Pkt., 10c.

Mammoth-Bright scarlet; good bedder. Pkt., 10c.

\section{SWEET VIOLETS}

Sow the seed in May, and when in flower in August and September, transplant in well enriched beds; soon after the snow is off in the fol-

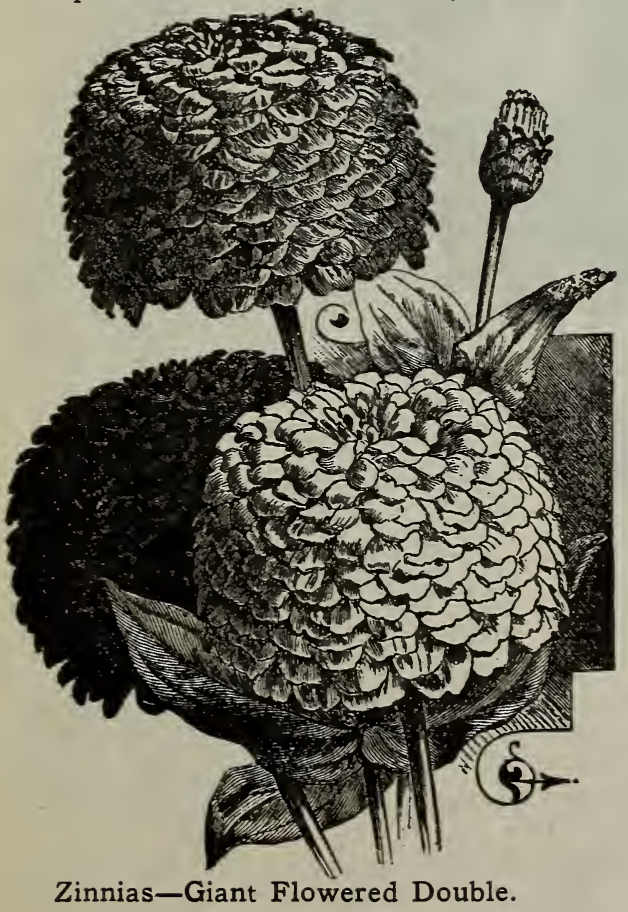
lowing spring they begin to bloom and throughout the spring will give a profusion of flowers. Blue, pkt., $5 c$.

\section{Flowering Sage}

Most gorgeous plants, with intensely vivid scarlet owers; a bed of them surpass the finest scarlet geraSplendentiliancy and contintious bloom.

Patens-The purest and brightest blue of all flowers. kt., 25c.

(Bonfire)-(See cut)-This new large two feet high by two feet in diameter. Color brilliant, azzling scarlet. Pkt., 20c.

SALVIA (Ball of Fire)-Of the many varieties now ers and is more free flowering than any other kind. The shoots producing from 4 to 6 flowering spikes so evenly hide the foliage.

Pkt., 25c.

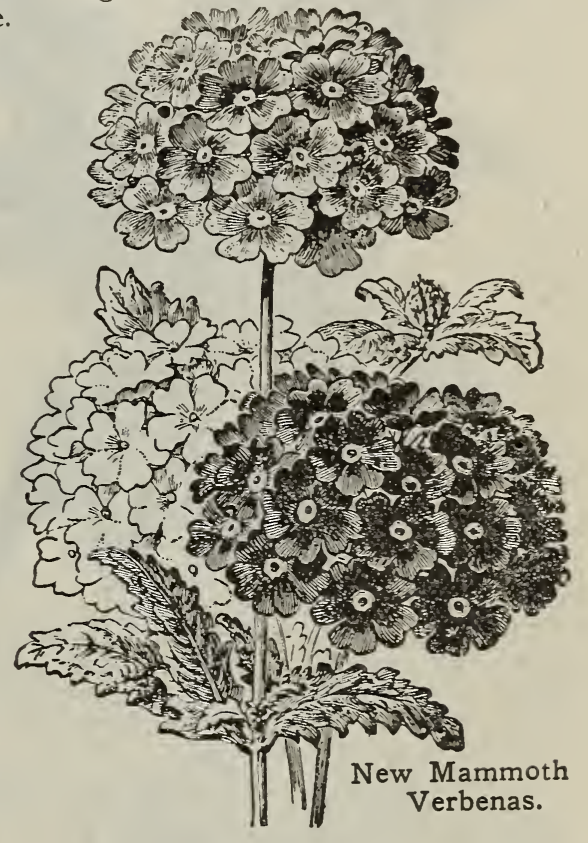

STOCKS (Gilly Flowers) - The Ten Weeks' Stocks are generally cultivated and bloom from ten to twelve weeks after being sown; they grow from 6 to 8 inches high, bearing an immense quantity of bloom of delightful fragrance. Mixed, pkt., $10 \mathrm{c}$.

VINCA-They flower from seed, if sown early, the first season, continuing until frost; or they may be potted and kept in bloom through the winter. Rosea-Rose, dark-eyed. Pkt., 10c. Alba Pura-Pure white. Pkt., 10c.

THUNBERGIA (Black-Eyed Susan)-Four feet, beautiful climbers for hanging baskets and lawn vases, flowers trumpet-shaped; mixed colors. Pkt., 5c.

\section{ZINNIAS}

A very showy plant, with large double imbricated flowers, which might easily be mistaken for Dwarf Dahlias. Sow the seed thinly in drills early in the spring, transplanting the young plants when 2 or $3 \mathrm{in}$. high to stand from $1 \frac{1}{2}$ to $2 \mathrm{ft}$. apart; or two or three seeds may be planted in a slightly raised hill.

Giant Flowered Double Mixed-This is a mixture of the largest Zinnias yet obtained, including the curled and crested varieties, with their most fantastic and graceful forms, as well as the Mammoth Zebra strains, with their curious markings. Pkt., 5c; oz., 50c.

Wallflower-Double dwarf branching. Mixed, pkt., 10c. 


\section{CHOICE SPRING BULBS}

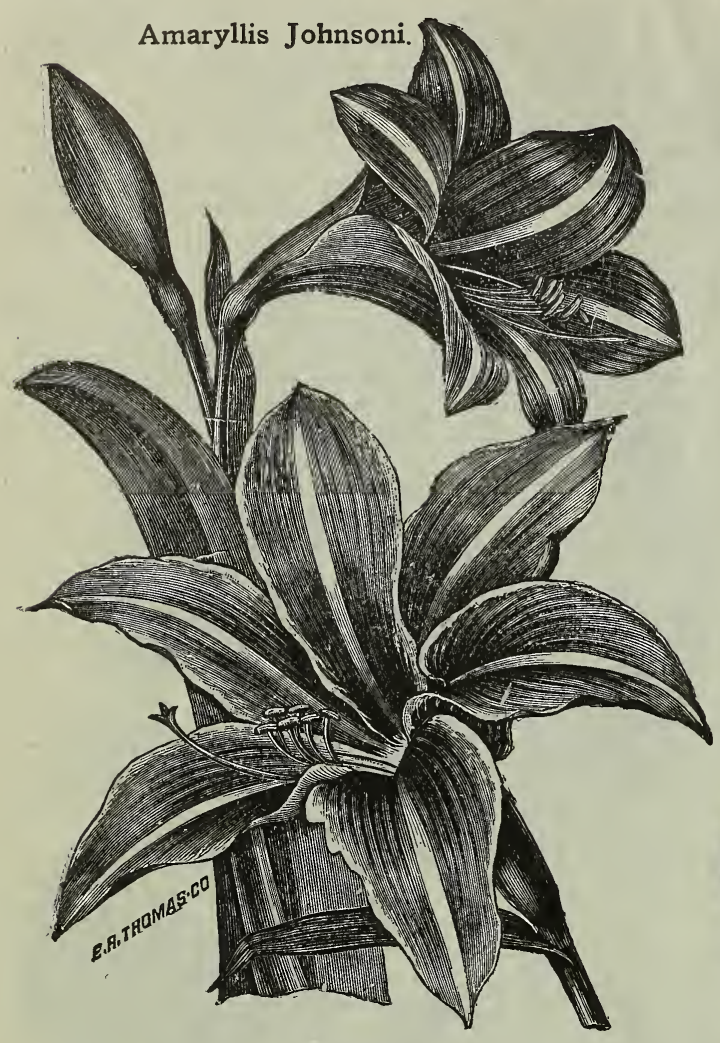

\section{Cannas}

Price: Large dry roots, 2 for $15 \mathrm{c}$; doz., 75c. Postpaid, each, 10c; doz., $\$ 1.00$. Growing plants, $10 \mathrm{c}$ each; doz., \$1.00. Postpaid, each, 15c; doz., $\$ 1.50$.

Burbank-Giant orchid flowers of rich, sulphur yellow, inner petals dotted with rich red; an excellent variety, blooms early and continuously. Foliage green and very compact. Height $4 \frac{1}{2}$ feet.

Buttercup-Flowers pure buttercup yellow with fine dots of bright red on lower petals. This is one of the oldest and best of the standards; always in bloom. Floliage green. Height 4 feet.

Chas. Henderson-Flowers brilliant crimson scarlet with yellow flame in throat; one of the best for bedding, a profuse bloomer; the great trusses of blooms always command admiration. Foliage green, dwarf and compact. Height $31 / 2$ feet.

David Harum-Bronze foliage; flowers scarlet, dotted crimson, 3 to $31 / 2$ feet.

Duke of Marlborough-Deep crimson maroon; 4 feet.

Egandale-Flower deep currant red of a peculiar and pleasing shade; it is an early and constant bloomer; one of the best bedders grown. Foliage rich bronze red. Height $31 / 2$ feet.

The Amaryllis is a window garden plant, producing under the simplest conditions one, two or even three spikes two feet or more high, which are crowned with from three to six large trumpet-shaped blooms which last long in good condition.

A. Johnsoni-The flowers of this magnificent variety are large and of fine crimson color, striped with white. Large bulbs, each, 40c; prepaid, 50c.

Formossissima-Can be grown in water same as Chinese Narcissus. Blooms early. Deep crimson. Each, $15 \mathrm{c}$; postpaid, 20.

Belladonna-A fall blooming sort with beautiful shell pink flowers on stems 18 to 24 inches high. They are exceedingly fragrant and very free of bloom. Each, 25c.

\section{Single Tuberous Begonias}

The Tuberose Rooted Begonias are among the most beautiful and desirable of all bulbous plants. For bedding in quantity, and when planted in partial shade and protected from severe storms, will give great satisfaction. Single mixed, all colors, 7c each; 4 for $25 c$; dozen, 70c, postpaid.

\section{Caladium Esculentum}

\section{Elephant Ear}

For obtaining tropical effects in lawn and garden planting, this beautiful plant takes a prominent place. Grows well in any garden soil, but should have plenty of water and good, rich soil to obtain best results. Extra large bulbs, $40 \mathrm{c}$ each; $\$ 4.00$ per doz. First size bulbs, 25c each; $\$ 2.50$ per doz. Add 10c each for extra large, and $7 \mathrm{c}$ for first size, if to go by mail. s

\section{(1)}
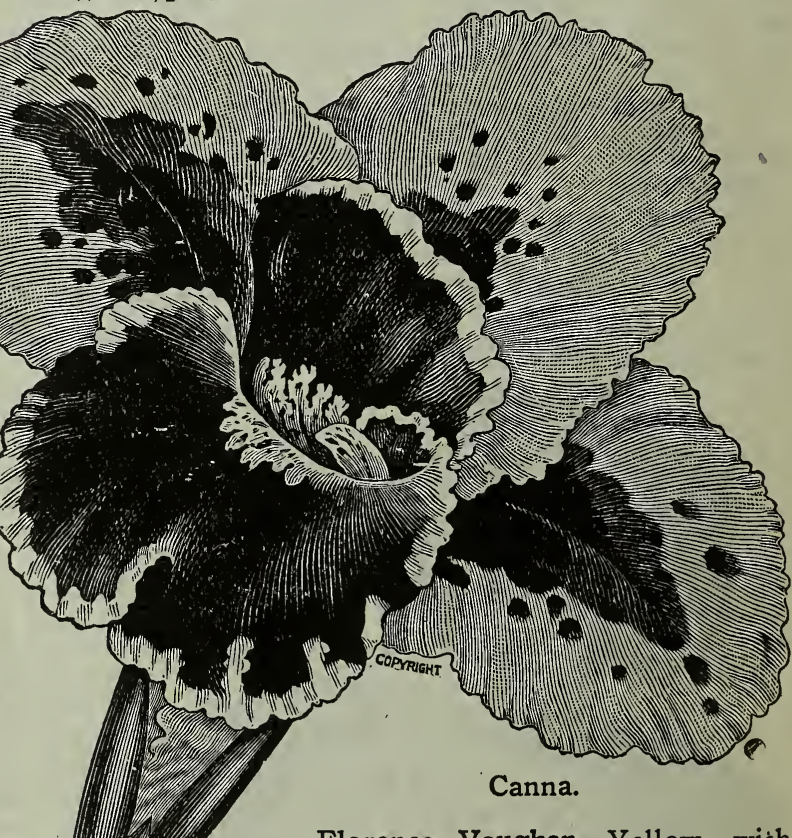

Canna.

Florence Vaughan-Yellow, with bright red spots; $4 \frac{1}{2}$ feet.

Florida - Flower large, orange scarlet in color, streaked and flamed with crimson and yellow; a good grower and profuse bloomer. Height 4 feet.

Gladiator-Big round flowers with bright yellow petals thickly spotted with crimson; smaller center petals of crimson; green leaves.

Grand Rogue-Handsome, crinkly leaves of darkest bronze, flowers red; 6 to 8 feet.

Italia-Orchid-flowering type; great, crinkly petals of clear yellow; irregularly overlaid with varied shades of orange scarlet; 5 feet. 
King Humbert-Nothing to equal it for "blazy" effects in bedding. Easily ahead of all bronze leaved Cannas, both in foliage and flower. Color fine orangescarlet, flaked carmine. Grows 4 to $4 \frac{1}{2}$ feet high and makes fine large clumps.

Louisiana-A bright crimson scarlet of the orchidflowered type; grows 5 to 6 feet high with immense spikes of bloom. Individual flower 5 inches across with correspondingly broad petals. Very showy in beds or as a center for more dwarf varieties.

Madame Crozy-Flowers brilliant vermillion scarlet with narrow gild edge, a very popular variety. Foliage bright green. Height $21 / 2$ feet.

Martha Washington-Dwarf, 3 feet. A handsome broad flowered rosy pink.

Mlle. Berat-Deep rose pink; 4 feet.

Mont Blanc-The only genuine pure white Canna; good heads of wide heavy bloom; 3 feet.

Mrs. Kate Gray-One of the finest orchid-flowered sorts; full of soft orange, shaded carmine and with dotted yellow throat; 6 feet.

Paul Marquant-Flowers salmon red, a very unique color; the blooms are large and borne in great clusters; it is a good variety for bedding. Foliage green; height $31 / 2$ feet.

Pennsylvania-Large orchid-flowered, scarlet; overlaid with orange; 5 to 6 feet.

Queen Charlotte-Dwarf scarlet, gilt edge; $21 / 2$ feet.

Rose Mawr-Bright rosy pink, mottled with rose, shaded golden yellow at throat; 3 feet.

Shenandoah-Flowers beautiful rosy pink, borne in large clusters. The foliage is very beautiful, being rich ruby red, exquisitely veined and tinted, resembling some rich tropical plant.

Venus-Warm rosy pink with irregularly mottled border of creamy yellow; green foliage.

Mt. Aetna-Leaves of rich bronze, large crimson flowers; 3 feet.

\section{Gladiolus in Colors}

We wish our customers to understand we carry no second size or No. 2 grades of bulbs. All are first size. Call at our retail store, 505 Walnut street, and we can quickly convince you. If to go by mail, add $5 \mathrm{c}$ per dozen.

These mixtures will be found to contain flowers equal to finest named kinds and a great range of shades, colors and markings. In assorted dozens you may rely on nearly every bulb to produce a different flower. The scarlets produce many shades of red and variations. This is also the case with the whites, which vary to light pink and lemon-tinted. Our mixtures contain all full-sized bulbs only; not bulblets. Plant in April and May, about 3 inches deep; in the fall bulbs may be taken up and stored in a dry, cool place.

Each. Doz. 100

Reds of various shades.................\$0.05 \$0.25 $\$ 1.50$

Light and white ............................ $05 \quad \begin{aligned} & .45 \\ & 2.25\end{aligned}$

Pink of various shades.....................

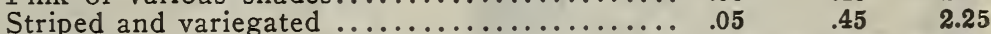

Yellow shades ............................. $.06 \quad .65 \quad 4.50$

Mixed, all colors ............................. $05 \quad .25 \quad 1.50$

\section{Hyacinthus Candicans}

A fine bulbous plant, producing in July and August a flower stem 3 to 4 feet high, covered with from 20 to 30 pure white pendant bellshaped flowers. It is hardy in most sections of the country, but north of this it would be better to protect it with leaves or long manure. Each, 10c; 2 for $15 c$.

\section{Gloxinia}

GLOXINIA-New Giant Flowered Hybrids-We know of no bulbous plants that will give such universal satisfaction as the Gloxinia. They are of unrivaled beauty, the soft velvety leaves being surmounted with a cluster of large, lovely, trumpet-shaped flowers of exquisite coloring. 'They are of the easiest culture and bloom continuously for months. Plant the bulbs in a 5 -inch pot in good, rich light soil, and give a partially shady situation. Mixed colors, each, 10c; 3 for $25 \mathrm{c}$.

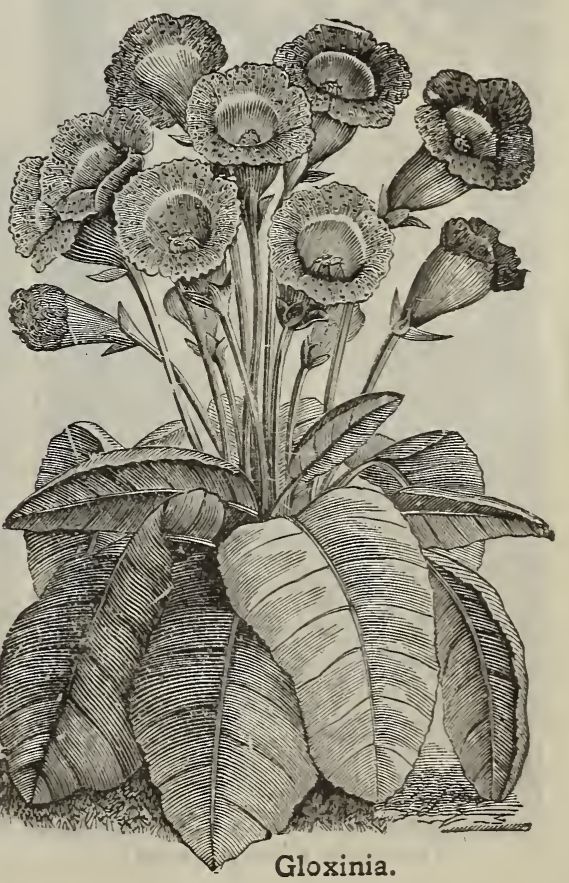




\section{Lilies}

The Lily, with eminent propriety, has been styled the "Queen of Flowers," and no flower is more expressive of the idea of queenly beauty and faultless purity than the lily. Their culture is simple, and with little care success is certain. They should be planted in the spring as soon as frost is out of the ground; in a well-drained spot, dig the soil deep, enrich it well, adding a liberal supply of sand. Set bulbs 4 to 6 inches deep. A bed once established should not be disturbed oftener than once in four or five years.

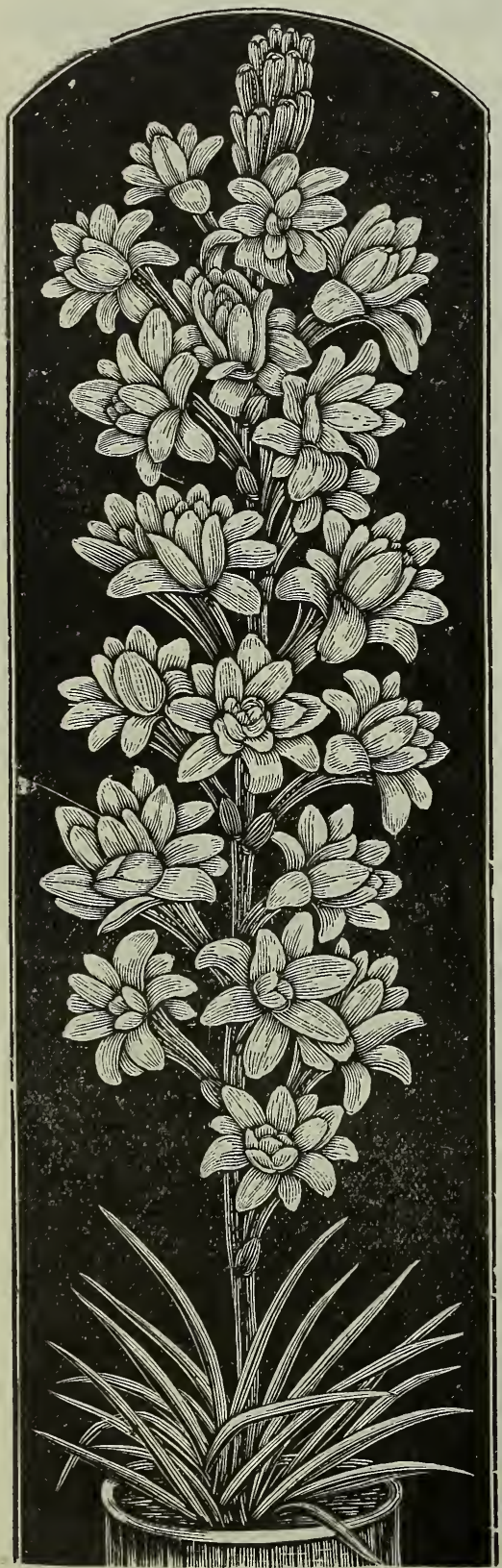

Tuberose (See page 39). grown. for cut flowers. rose.
Auratum-The glorious gold-banded Lily of Japan, and one of the grandest plants in cultivation. Its immense, ivory flowers are thickly studded with yellow and crimson spots, while in the center of each petal is a gold band, fading at the edges into white. Each, 25c; 2 for $45 \mathrm{c}$; doz., $\$ 2.50$.

Speciosum Album-Pure white flowers, with a greenish band through the center of each petal; they are of great substance and very fragrant. Each, 20c; 2 for $35 c$; doz., $\$ 2.00$.

Speciosum Rubrum-White, shaded and spotted with rose or crimson. Each, 20c; 2 for $35 \mathrm{c}$; doz., $\$ 2.00$.

Tigrinum fl. pl. (Double Tiger Lily)-Very hardy and free blooming, with beautiful orange flowers, spotted with black. Each, 15c; postpaid, 20c.

\section{Harnden's Collection of Choice Paeonies}

Harnden's Collection of Choice Paeonies, Old Fashioned, but still popular-Valuable for massing in beds or planting in groups. Can be produced in any good rich soil. Grow best in sunny positions, but thrive almost equally as well in shaded places. Once planted will last a lifetime. Perfectly hardy, require no protection whatever, and are not troubled with insect pests or disease of any kind.

Our collection comprises the choicest varieties which have been grown for us in Holland. Each, 35c; by mail add 10c per bulb; $\$ 3.50$ per dozen by express, not prepaid, except where otherwise noted.

Duchess de Orleans-Large and compact, guard petals, closely overlapping center; rosy, lake, with incurving salmon center.

Festiva Maxima-Very large pure white inner petals, slightly striped carmine; borne on long stiff stems. One of the most popular Paeonies

Fragrance-Bright purplish crimson or dark rose; one among the best

La Esperance-Dark rose.

Officinalis Rubra-This is the old-fashioned red, the most brilliant of all red Paeonies. Early and splendid cut flower.

Princess Mathilde-Delicate pink; high, full center.

Purpurea-Dark purple.

Queen Victoria-Best early white.

Rosea Elegans-Outside petals rose, center creamy white, suffused with

Rosea Magna-Beautiful clear pink of large size.

Rubra-Dark crimson.

Rosea Superb-Fine silvery rose, large size.

Double Pink, Double Red, Double White, each, 25c; doz., \$2.50.

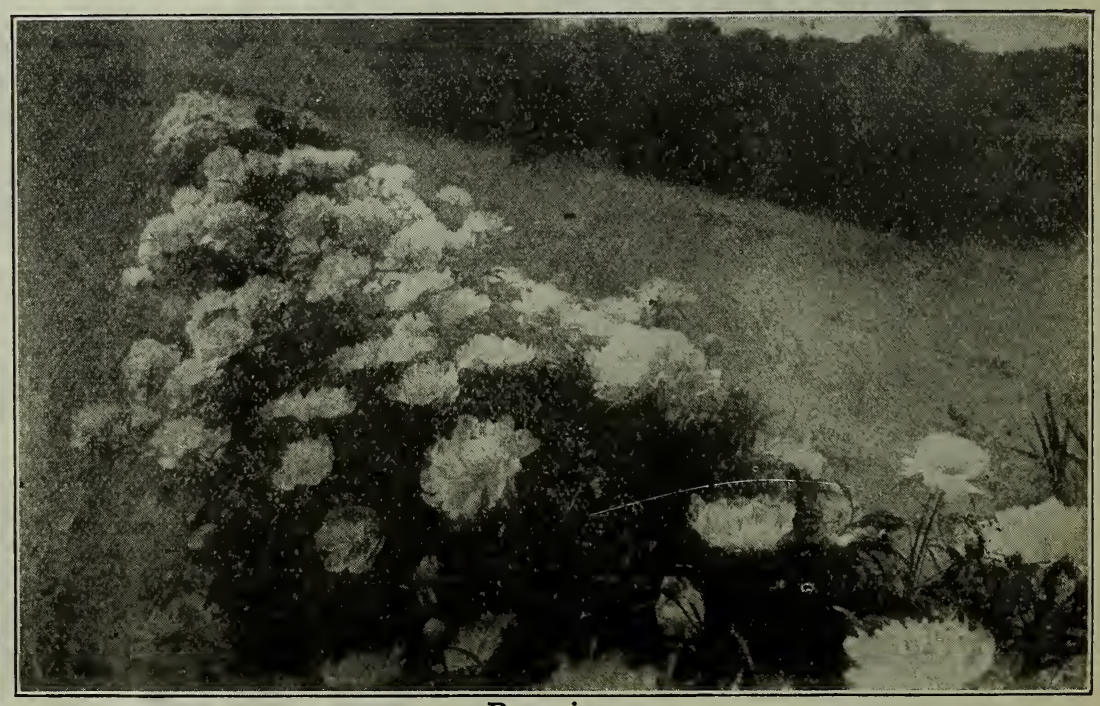

Paeonies 


\section{Dahlias}

Especial attention is being given to the culture of these splendid fall bloomers. Coming as they do, after most other flowers are gone, their bright colors and cheery appearance lend a charm to the table or center-piece. Everyone should have a few of these oldtime flowers. Our stock has been selected with great care.

Set out three feet apart, after all danger of frost is over. The plants should be supported by tying to stakes.

If to go by mail, add $8 \mathrm{c}$ per bulb.

\section{Cactus Dahlias}

Edith Groom-Pure white, large 'size, with twisted petals. Each, $35 \mathrm{c}$; per doz., $\$ 3.50$.

Kriemhilde-Beautiful clear pink, tinting lighter toward the center. Each, 25c; per doz., \$2.50.

Meteor-Ruby red, with purple shadings. Each, 20c; doz., \$2.00.

H. F. Robertson-Pure, deep yellow; more intense in color than any other Cactus variety. Petals are narrow from base to tip.

\section{Show Dahlias}

Miss Dodd-Pure yellow, of exquisite form; handsome flowers. Eacin, $15 \mathrm{c}$; per doz., $\$ 1.50$.

A. D. Livoni-Beauriful soft pink, with quilled petals. The standard pink for cutting. Each, 15c; per doz., \$1.50.

Storm King-Still the finest of all white Show Dah. lias. An extremely early, profuse and constant bloom-

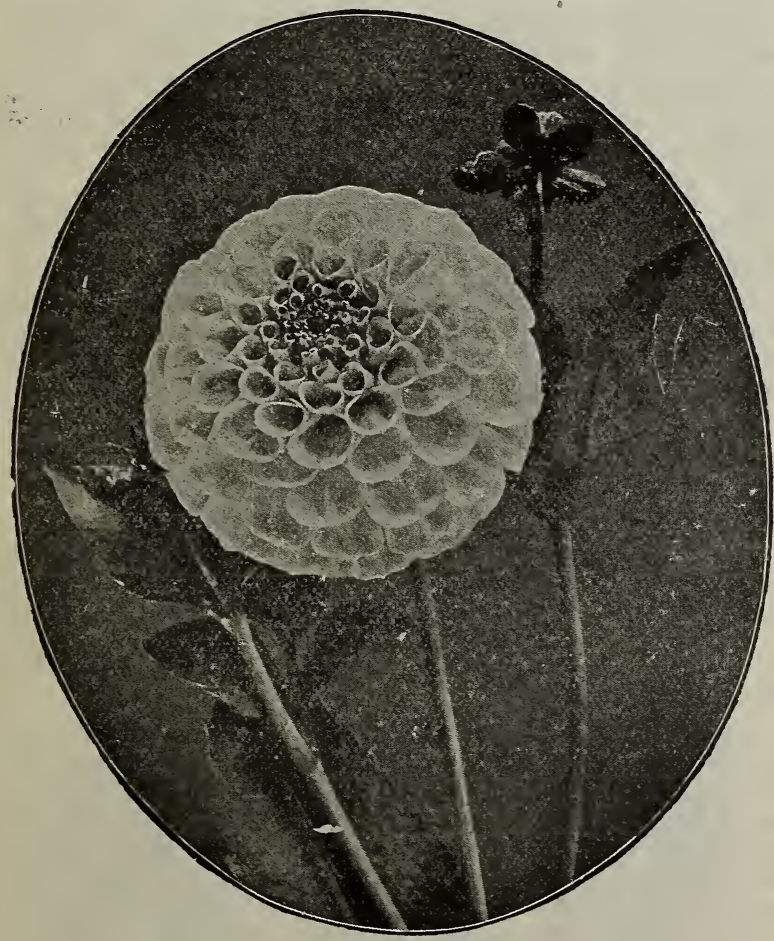

A. D. Livoni

er. A strong, vigorous grower of dwarf, branching habit, producing large, perfectly shaped flowers on long, stiff stems. Each, 25c; per doz., \$2.50.

Kaiser Wilhelm-Very large, fine form; quilled petals; yellow, lightly tipped crimson. Each, 20c; per doz., \$2.00.

Queen Victoria-Deep yellow, finely quilled. Each, $15 \mathrm{c}$; per doz., $\$ 1.50$.

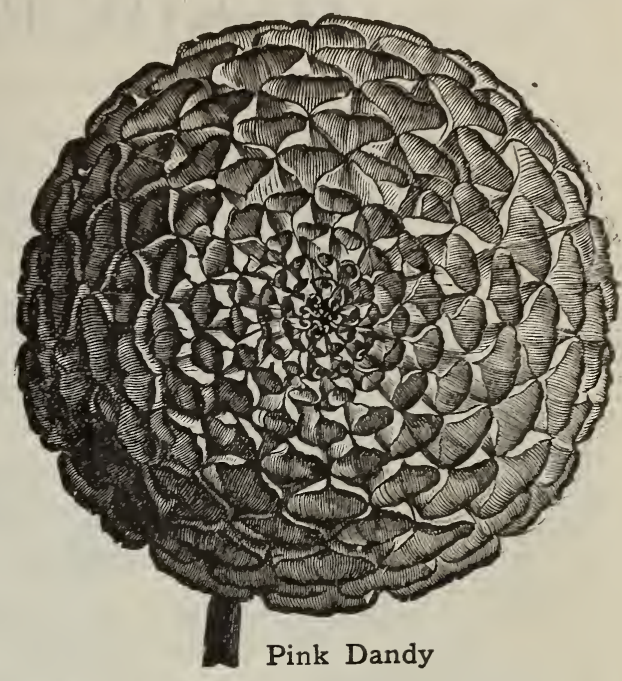

Lady G. Herbert-White, tipped deep purple. Each, 15 c; per doz., $\$ 1.50$.

Queen of the Belgians-Very delicate, blush pink; round form; full high center, early and profuse bloomer. Each, 25c; per doz., \$2.50.

Pink Dandy-Beautiful clear pink, quilled petals, Each, 20c; per doz., \$2.00.

Jack Rose-Flowers large to very large; of perfect form, full high center, while the outer petals reflex. The flowers are produced on long, slender, erect stems in the greatest abundance and keep longer when cut than any other variety. Color of Jack Rose is that old favorite "Jack Rose" (General Jacqueminot) from which it received its name. That rich, velvety crimson cannot be found elsewhere. Each, 35c.

\section{Decorative Dahlias}

Admiral Dewey-Brilliant, imperial purple.

William Agnew-Finest red ever introduced; immense size. Each, 20c; per doz., $\$ 2.00$.

Clifford W. Bruton-The best yellow. Immense size, perfect form. Finest canary yellow. Each, 20c; doz., $\$ 2.00$.

Henry Patrick-Large, pure white; long stems. Each, 25c; doz., \$2.50.

Lyndhurst-One of the best bright scarlets; invaluable for cutting. Each, 15c; per doz., $\$ 1.50$.

Nymphaea-The most delicately beautiful of the entire collection. Color clear, light shrimp, pink, tinting lighter toward the center. Each, 20c; doz., \$2.00.

\section{Tuberoses}

Excelsior Pearl-Very sturdy and dwarf in habit; flower large and double. Each, 5c; doz., 35c; by mail 45 c doz.; per $100, \$ 2.00$, not prepaid.

SUMMER FLOWERING OXALIS-These useful little plants are very effective in masses or beds, and are particularly valuable for edging. They produce an unbroken row of foliage and showy flowers. Mixed, per duz., 10c.

MADEIRA VINE-Tuberous rooted climber, with glossy green leaves, and delightfully fragrant white blossoms; of very rapid growth. 2 for $5 c$; doz., 30c; postpaid, doz., 35c. 


\section{HARDY PERENNIAL PLANTS}

These plants live through our winters with little protection. When once planted, always stay.

AQUILEGIA (Columbine)-A beautiful plant for the border or rockery; flowers often three inches in diameter; height of plant two feet. Large field clumps, each, 20c; doz., \$2.20.

COREOPSIS LANCEOLATA-Flowers bright golden yellow, blooming from June until frost; height 11/2 feet. Each, 15c; per doz., $\$ 1.50$.

DIELYTRA (Bleeding Heart)-One of the most beautiful hardy border plants. Flowers in early spring, with rose-colored heart-shape flowers on under side of stem. Perfectly hardy. Each, 35c.

DELPHINIUM FORMOSUM (Larkspur)-The best known of all the Larkspurs, blooming in long trusses of deep blue flowers, with white eycs. Each, 20c; doz., $\$ 2.00$.

GAILLARDIA GRANDIFLORA COMPACTA-Is a very satisfactory hardy plant; begins to bloom in early summer and blooms until frost; brownish red center; petals shaded into rings of orange, crimson and red. Long stems, fine for cutting; perfectly hardy. Each, $15 \mathrm{c}$; per doz., $\$ 1.50$.

HOLLYHOCKS-An old-fashioned plant, coming into general use again. For planting in masses, by itself, or as a background. Each, $15 \mathrm{c}$; doz., $\$ 1.50$.

ORCHID FLOWERED GERMAN IRIS-One of the prettiest of the type; the ground work being pure white, overlaid and penciled with the daintiest blue. Each, 10c; doz., \$1.00.

\section{Papaver-Perennial Poppy}

Orientale-A charming species, producing numerous stout leafy stems, $21 / 2$ feet high, with immense deep red flowers, having a black blotch at the base of each petal. Each, 20c; doz., \$2.25.

Nudicaule (Iceland Poppy)-A beautiful class of hardy Poppies; flower stems about a foot in height, bearing elegant cup-shaped flowers, ranging in color from pure white and yellow to deep orange scarlet; waluable for cut flowers, lasting well when cut, and

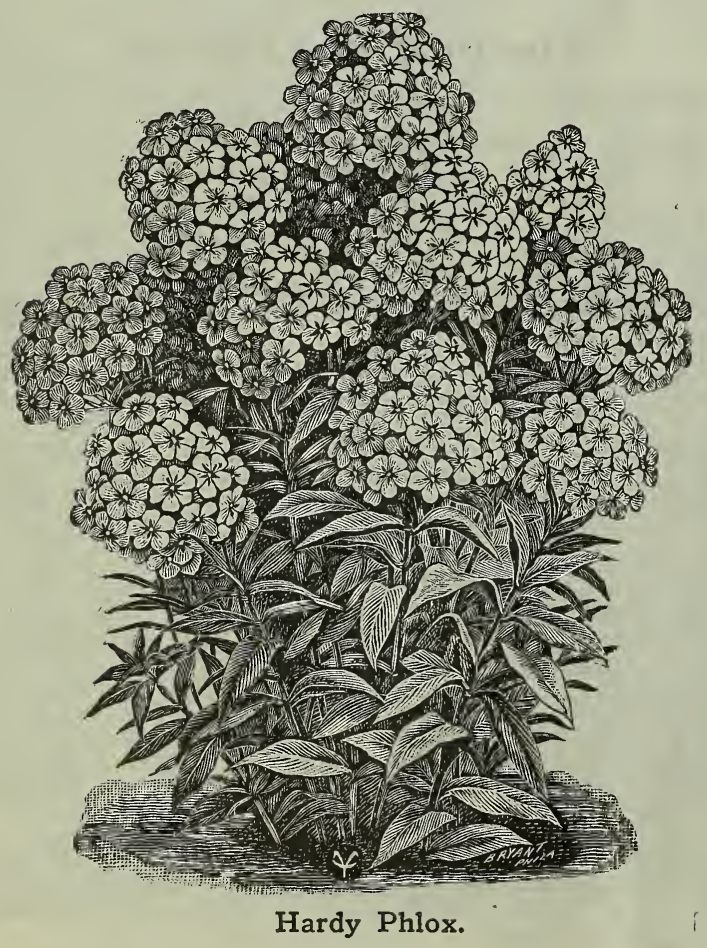

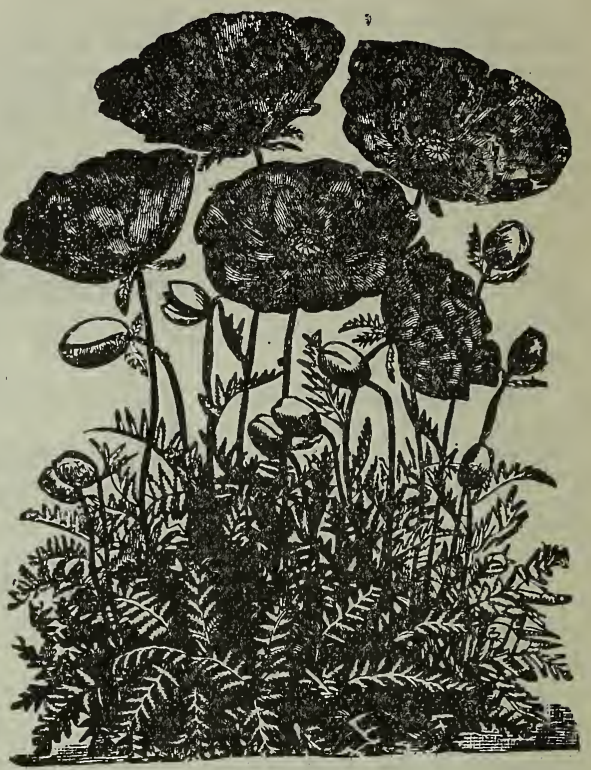

Papaver.

having a pleasant lilac perfume. We offer in separate colors, white and yellow. Each, 15c; doz., \$1.50.

HARDY PHLOX-Thrive in any ordinary rich soil, the ease with which they are cultivated, their entire hardiness, and the extended season of blooming make them particularly valuable for garden planting. To prolong the season of blooming, the flowers should be cut off when they commence to wilt down. Field-grown clumps in separate colors, each, $15 \mathrm{c}$; per doz., $\$ 1.50$.

PLATYCODON GRANDIFLORA (Japanese Bell Flower)-Blooms constantly from June until late in September; flowers large, bell shaped, white and blue; perfectly hardy; three feet high. Each, 15c; doz., \$1.50.

PINKS (Hardy Garden or May)-Valuable dwarf hardy plants, that will grow anywhere, and increase in beauty every year; field grown clumps. Each, 15c; doz., $\$ 1.50$.

RUDBECKIA (Golden Glow)-Decidedly one of the brightest and most showy among the hardy plants. It grows five to seven feet tall, with broad heads of yellow flowers, two and three inches in diameter; increases in beauty every year; strong field roots. Each, 15c; doz., $\$ 1.50$.

STOKESIA CYANEA (Corn Flower Aster)-A grand, large flowered hardy perennial that is 18 to 24 inches high, covered with large Centaurea-like flowers of a beautiful lavender blue shade. Blooms July to October, even after frosts have destroyed many of our outdoor flowers. Of easiest possible culiure, flourishing wherever given an open, sunny exposure. As a single specimen plant, used in mixed borders, or in large masses by itself, it is equally valuable, and by its use some very effective plantings may be worked out. Each, 20c; doz., $\$ 2.00$.

TRITOMA PFITZERI-An improved type of more perfect form, and showing a marked predominence of scarlet, the opened lower petals merely being rimmed with orange. Each, 20c; per doz., $\$ 2.00$.

SWEET VIOLET PLANTS-50c per doz.; $\$ 3.50$ per 100 , not prepaid. 


\section{HARDY ROSES FOR OUTDOOR PLANTING}

Hybrid Perpetual Roses are the most valuable roses for outdoor planting wherever a permanent bed is desired. They are perfectly hardy and will stand our most severe winters, and when once established they improve in beauty every year. They will do well almost anywhere, but delight in a deep, rich soil. A mulching of straw or leaves will greatly benefit them if applied in the fall and allowed to remain until spring. Our collection contains the choicest of the new and old varieties; twoyear-old, outdoor grown, dormant plants. Price, unless otherwise noted, 35c each; 3 for $\$ 1.00$ : $\$ 3.50$ per doz., not prepaid; by mail, add 7c per plant.

American Beauty-The largest, sweetest and best of all hardy roses; a genuine hardy ever-blooming rose; color rich crimson; its fragrance is wonderfully sweet. Each, 50c; 3 for $\$ 1.35$; per doz., $\$ 5.00$.

White American Beauty-A counterpart of the Red American Beauty, except in color; perfectly hardy everywhere; pure paper white, with bright, heavy foliage and strong upright growth. The bloom is perfect in form, on fine long stems. Each, 50c; 3 for $\$ 1.35$; per doz., $\$ 5.00$.

Baron de Bonstetten-Still the leading dark rose. A splendid shade of dark red, changing to velvety maroon. It blooms very freely and makes a fine shaped bush.

Coquette des Alps-Large, full, finely formed flower; color white, sometimes faintly tinged with pale blush; profuse bloomer. Each, $40 \mathrm{c} ; 3$ for $\$ 1.10$; per doz., $\$ 4.00$.

Conrad F. Meyer-An early flowering Hybrid with large cup-shaped flowers of a beautiful silvery pink.

General Jacqueminot-Rich velvet crimson, changing to scarlet crimson. A magnificent rose and well known.

General Washington-Color bright shining crimson; flowers large and perfectly double; blooms the first season and almost constantly.

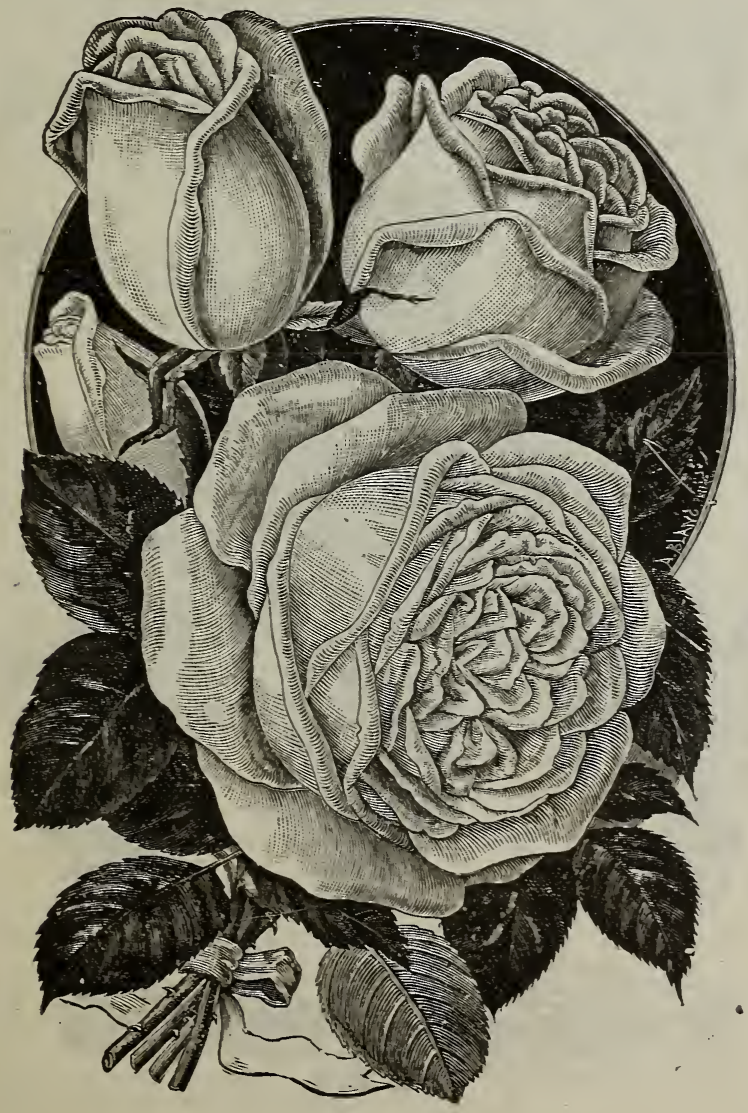

John Hopper-One of the most popular of the hardy perpetuals; flowers large and full; color, brilliant rose, changing to pink, shaded with crimson; sweet and a profuse bloomer.

Hugh Dickson-Magnificent crimson, shaded with. scarlet. Flowers very large, of perfect shape, and fully. double. Each, $40 \mathrm{c} ; 3$ for $\$ 1.10$; per doz., $\$ 4.00$.

Lyon Salmon Pink-Each, 50c; 3 for $\$ 1.35$; doz., $\$ 5.00$.

Marshal P. Wilder-A rose of unusual excellence; flowers large, color bright cherry red, changing to crimson.

Meteor-The color is rich, velvety crimson, very bright and attractive. The plant is of vigorous growth and a very free bloomer.

Mrs. John Laing-A splendid hardy perpetual. Immense flowers, full and double; bloom on long, stiff stems in great profusion and exceedingly sweet; buds. long and pointed; color bright, shining pink, exquisitely. shaded.

Mme. Gabriel Luizet-Pink or coral-rose, large and very double, of good form and substance. A very splendid variety, full cupped and very sweet.

Paul Neyron-The largest flowered in cultivation and one of the most prolific bloomers; color, deep, clear rose, very fresh and attractive. The plant is an exceptionally good grower, making straight shoots 4 to 5 feet high in one season, and each shoot tipped with an immense flower, often 5 inches in diameter.

Prince Camille de Rohan-Very dark crimson, changing to intense maroon.

Soliel d'Or (Golden Sun)-A new hardy yellow rose, thoroughly distinct in habit of growth; color a blending of reddish gold, orange, yellow nasturtium, red and pink, not found in any other rose, from which it derives its name, "Golden Sun." A strong, robust flower; petals well incurved, forming double flowers. The colors of this rose are not found in any other flower. Each, 50c; 3 for $\$ 1.35$; per doz., $\$ 5.00$.

Ulrich Brunner-Known to all planters as one of the best flowers, very large, rich, globular; color rich crimson, flamed with scarlet; hardy, fragrant and a free bloomer. 


\section{Collection of Ever-Blooming Hardy Tea Roses}

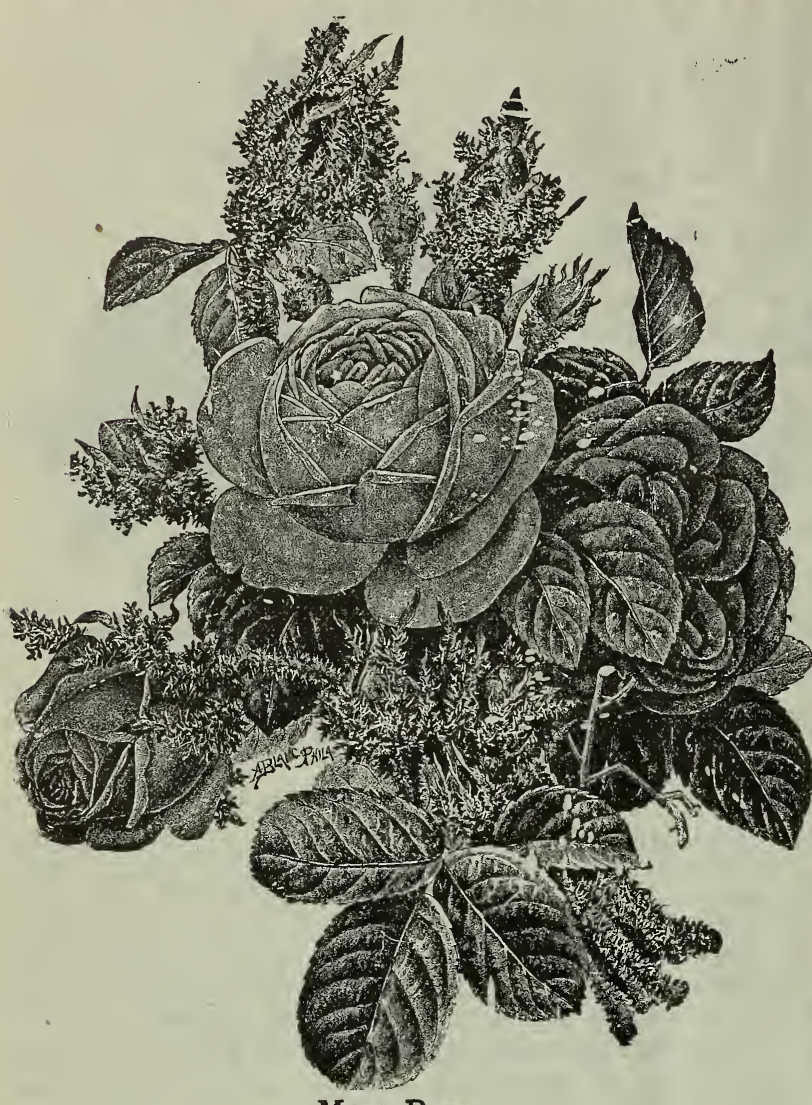

Moss Rose.

\section{Moss'Roses}

No rose garden is complete without the Moss Rose. They are as hardy as any rose can be, and are vigorous growers and are much admired on account of their beautiful buds, which are covered with a moss-like covering. They bloom but once a year, but the flowers are large, beautiful and plentiful. Strong field-grown plants. Price, each, $40 \mathrm{c}$; 2 for $75 \mathrm{c}$; not prepaid.

Blanche Moreau-Large, fully flowered, creamy white, tinged with rosy blush; fragrant and beautiful, fully mossed.

Salet Moss-One of the very best. Beautiful light rose; medium size; flat form and very free bloomer.

Luxemburg-Bright crimson. Large and beautifully mossed.

\section{Rose Trees}

Rose trees are grafted on hardy rose stocks; are tree shaped and when in bloom are objects of beauty; very handsome plants for the lawn or rose border. We offer these in different colors. Crimson Rambler. Everblooming Tree Roses. Each, 75c; 3 for \$2.00; per doz., $\$ 7.00$.

American Beauty-Each, $\$ 1.00$.

Baby Rambler Tree Roses-An attractive novelty in hardy roses, the most striking of all tree roses. Each, $\$ 1.00$.

Red and White on same stem, each, \$1.25.

These are sent by express or freight only, not prepaid.
Killarney (The New H̄ardy Everblooming Irish Hybrid Rose)-A native of the North of Ireland. Strong upright bush, with beautiful deep bronze-green foliage; free flowering, bearing its massive flowers on long stiff stems. In color, exquisite shade of deep, brilliant shell pink. Delightful tea fragrance, a continuous bloomer, two years old. Each, 35c; 3 for $\$ 1.00$.

Kaiserin Augusta Victoria-As hardy as any of the Hybrid Tea Roses, and blooms from early spring until late frosts, fully as' free blooming as any Tea Rose. Color delicate creamy white, large, full double flowers and very fragrant. Two years old. Each, 35c; 3 for $\$ 1.00$, not prepaid.

Etoile de France (Star of France)-A magnificent new rose. Healthy, hardy grower and abundant bloomer, buds pointed. Flowers large, double, $31 / 2$ to $4 \frac{1}{2}$ inches in diameter, particularly valuable for planting in the open ground. Flowers clear red, or crimson velvet, brightening in the center; exquisitely fragrant. Twoyear-old hardy plant. Each, 50c; 3 for $\$ 1.35$.

Grus an Teplitz-One of the brightest colored Roses grown, when first opened it is dark rich crimson, changing to bright scarlet, shading to fiery red; blooms continually. Two-year-old hardy plants. Each, 40c; 3 for $\$ 1.10$.

Souv. De Pres. Carnot-The flower is large, exquisite shape; delicate rosy flesh, shade deeper at the center. Each, 35c; per doz., $\$ 3.50$.

Perle Des Jardins-Beautiful clear yellow; distinct from all other tea roses. Two years old. Each, 35c; per doz., \$3.50.

La France-The most perfect type of a cut flower rose; delicate silvery rose, shaded with pink flowers continually throughout the season. Each, 35c; 3 for $\$ 1.00$; per doz., $\$ 3.50$.

Hermosa-Always in bloom, and always beautiful, the color is a most pleasing shade of pink. Each, $40 \mathrm{c}$; 3 for $\$ 1.10$; per doz., $\$ 4.00$.

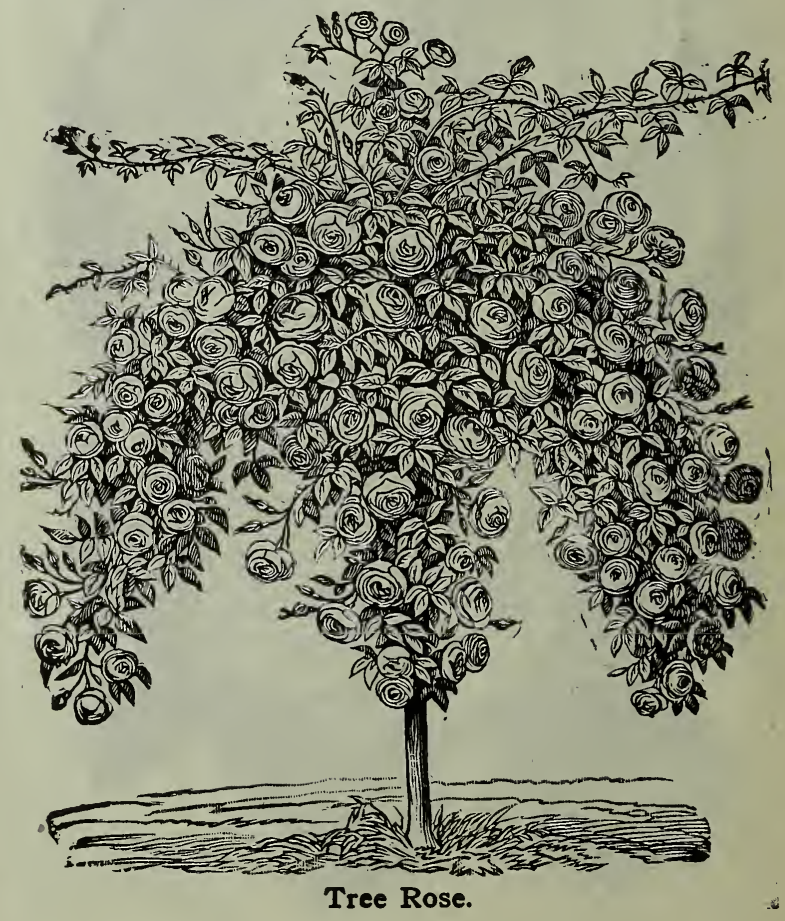




\section{GENERAL COLLEGTION OF HARDY ROSES}

\section{A BLUE ROSE \\ The Long-looked for \\ Novelty an Accomplished Fact}

\section{The Blue Rambler Rose--.-.}

Veilchenblau or Violet Blue is the proper name. This Rose first opens pink, but quickly changes to Violet Blue; some describe it as a Steel-Blue. The blossoms, massed in large umbels, are semi-double, of medium size. The plant is vigorous in growth, with shining green foliage. Each, $\$ 1.00$.

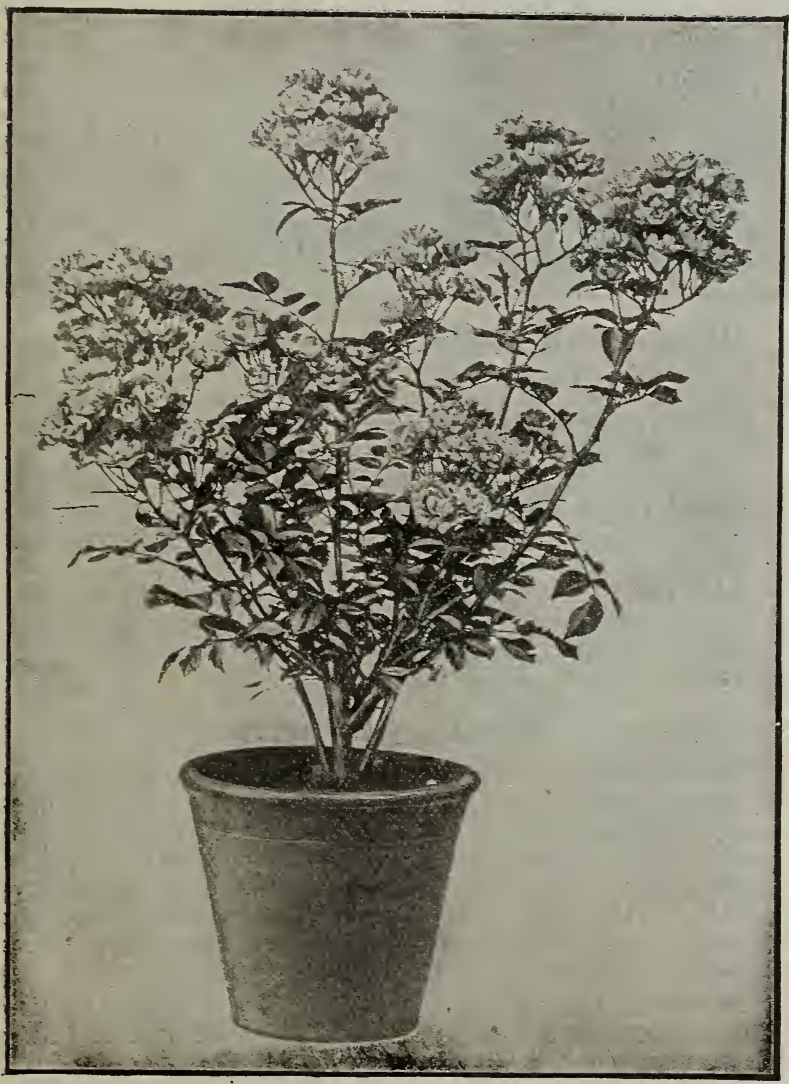

Baby Rambler.

\section{Baby Rambler}

A dwarf form of Crimson Rambler, blooming out of doors throughout the entire season until frost. Blooms in clusters of 25 to 40 flowers at one time. One of the very best for bedding, and may be grown in pots just as easily as any of the old-time pot plant varieties. With ordinary care will grow and bloom from one year's end to another. Strong two-year-old plants, 40c; $\$ 4.00$ per doz., not prepaid.
EVERBLOOMING CRIMSON RAMBLER (Flower of Fairfield)-A sport from the famous Crimson Ramblers, same climbing habits and hardiness. Has immense trusses of bloom similar in color, but more brilliant and lasting. It blooms profusely on the young wood in its first year. It starts blooming in early spring and continues to bloom until late in the autumn. It is rightly termed perpetual bloomer. Each, 50c; 3 for $\$ 1.35$; per doz., $\$ 5.00$.

\section{Climbing Roses}

Most desirable for covering trellises, walls or porches, as they are vigorous growers and succeed almost anywhere when once planted.

Each, 40c; 3 for $\$ 1.10$, not prepaid.

Prairie Queen-An old standard variety. No collection of hardy climbing roses is complete without it. Bright rosy red, large, compact and globular flower; very vigorous in growth.

Dorothy Perkins-Properly classed as a climbing rose; sweet scented, hardy and vigorous; a profuse blooner; flowers double, bloom in clusters of from six to ten, with crinkled petals; buds pointed. Color a beautiful shell pink, lasting a long time without fading.

\section{Everblooming Climbing Roses}

Climbing L. France-A distinct climbing form of the pink La France. Each, 40c; 3 for $\$ 1.10$.

\section{Rambler Roses}

We offer to our customers this year four popular Ramblers: Crimson, Yellow, Pink and White.

Prices: Large two-year-old dormant plants, field grown, by express, not prepaid-40c each, 3 for $\$ 1.10$; per doz., $\$ 4.00$.

Crimson Rambler-The Crimson Rambler is the most popular of the Rambler varieties. It begins to flower about the middle of June and remains in flower longer than any other hardy, out-door rose. It blooms in large clusters, with from 50 to 100 in a cluster, covering the vine its entire length with a solid mass of the most beautiful and perfectly shaped miniature crimson blossoms. It is vigorous in growth, often making shoots 10 to 12 feet long in one season. May be grown in any position, pegged down to the ground in beds, trained to porch pillars, the side of a building, or on trellises.

Yellow Rambler-The one yellow hardy climbing rose, and beautiful when in bloom, whether planted by itself or grouped with other Ramblers. Flowers yellow, borne in clusters.

Pink Rambler-Resembles the Crimson Rambler in every respect except color, which is a clear pink, often changing to a creany white when fully matured.

White Rambler-A worthy companion for the other Ramblers. Same in habit of growth, form and flowers. Perfectly hardy; flowers borne in good-sized clusters. The pcarly white flowers contrast nicely with those of the Crimson Rambler, and makes a beautiful display when planted together. Flowers are quite fragrant and last a long time after being cut. 


\section{HARDY ORNAMENTAL SHRUBS}

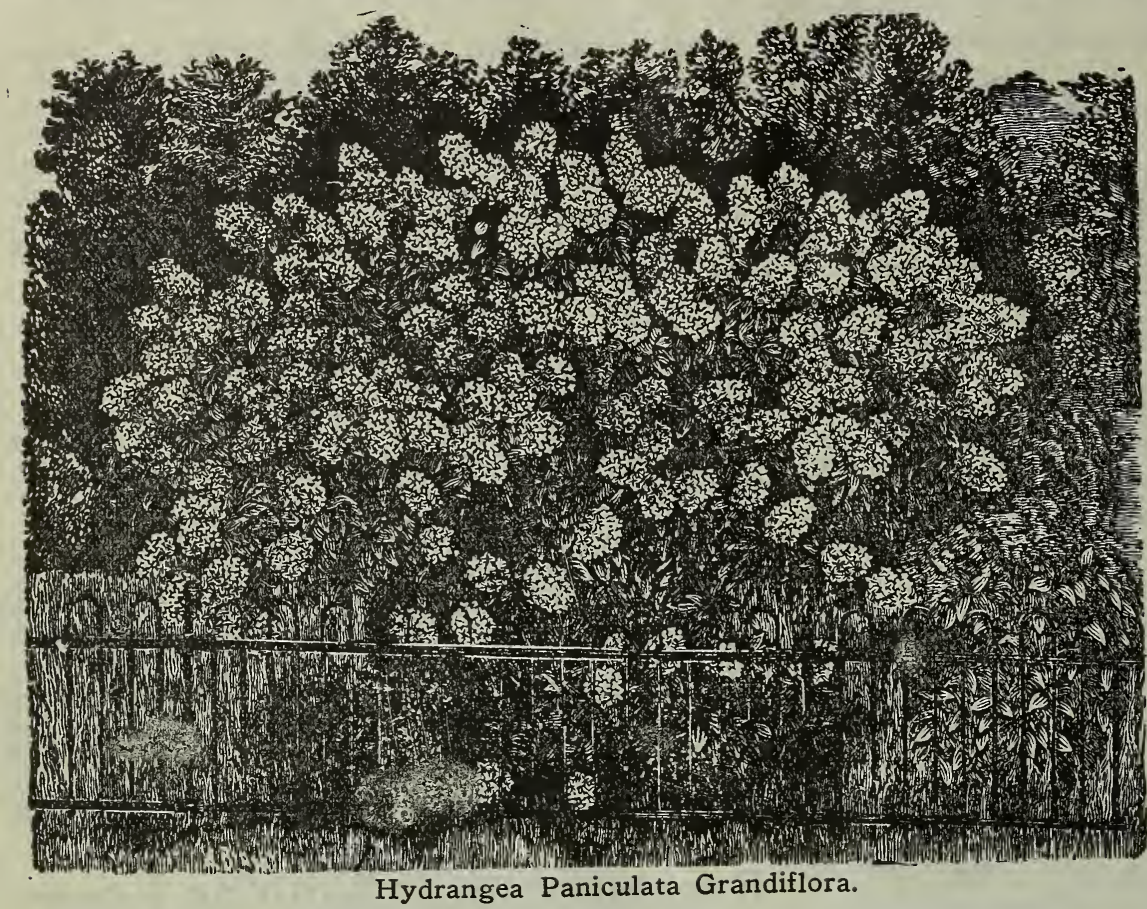

LILAC (Persian) - Purple and white. Each, 45c.

PHILADELPHUS (Mock Orange)-Vigorous growing shrubs, with fine, pure white flowers and bright, handsome foliage. Each, 50c.

PLICATUM (Japan Snowball)-Used extensively for decorating. Flowers pure white, large balls frequently borne in clusters of five or six. Each, 50c.

RHODODENDRONS Are most effective. They will grow in any good soil, but do better in a sheltered location where the soil is deep and well drained. Leaves make the best winter protection. Their summer blooming can be compared only to the Magnolia. in winter the great leathery leaves form rich banks of green. Blooms May and June. Large, well budded plants, each, $\$ 3.00$.

W E I G E L A - Beautiful shrubs; bloom June and July; very desirable for border or grouping. Double White and Double Pink. 50c each.

SPIREA VAN HOUTTEI-One of the most beautiful of all shrubs; pure snow-white flowers, borne in elegant plume-shaped clusters. Large plants, each, $45 \mathrm{c}$.

THUNBERGII (Thunberg's Spirea)-A very pretty white flowering variety, with narrow linear leaves; valuable for forcing; one of the first to flower. Each, 45c.

PRUNIFOLIA (Bridal Wreath)-Equally pretty like above; blooms in May, with pure white double flowers. Each, $45 \mathrm{c}$.

ANTHONY WATERER-A dwarf bush about 2 feet high, covered from spring to late in the fall with large heads of crimson flowers; grand for border to taller growing shrubs. Fine plants, each, 45c.

\section{Hedge Plants}

CALIFORNIA PRIVET (Ovalifolium)-The great hedging plant, conceded the best plant for hedging purposes. Remarkable for the beauty of its evergreen foliage and strong, regular, symmetrical growth. Foliage dark green, very glossy and wax-like; hardy everywhere. Better than Boxwood. Large Plants: One year old-10c each, 25 for $\$ 2.00 ; \$ 5.00$ per 100 . Two years old-15c each, 25 for $\$ 3.00 ; \$ 8.00$ per 100 .

BOX WOOD PLANTS-These are used extensively for lawn and porch decorations. Standards, each, \$2.00; Pyramidal, each, $\$ 2.00$; Bush, each, $\$ 1.50$.

BALL FORM-Each, \$2.50.

MAGNOLIA-Handsome beyond description. Their great white, pink and purple cups open in great profusion before the leaves of other trees appear; leaves tropical in size and appearance. One of the most beautiful species of flowering trees. Should be planted in the spring. Each, $\$ 2.50$.

CATALPA BUNGEI-Dwarf species from China, 3 to 5 feet high. Foliage large and glossy; very graceful and handsome. Grafted on stems 6 to 8 feet high it forms a pretty dome-shaped head of great soft heavy leaves, laying in shingle-like precision. Hardy, strong growing and unique. Price, each, $\$ 2.00$. 


\section{HARDY ORNAMENTAL CLIMBING VINES}

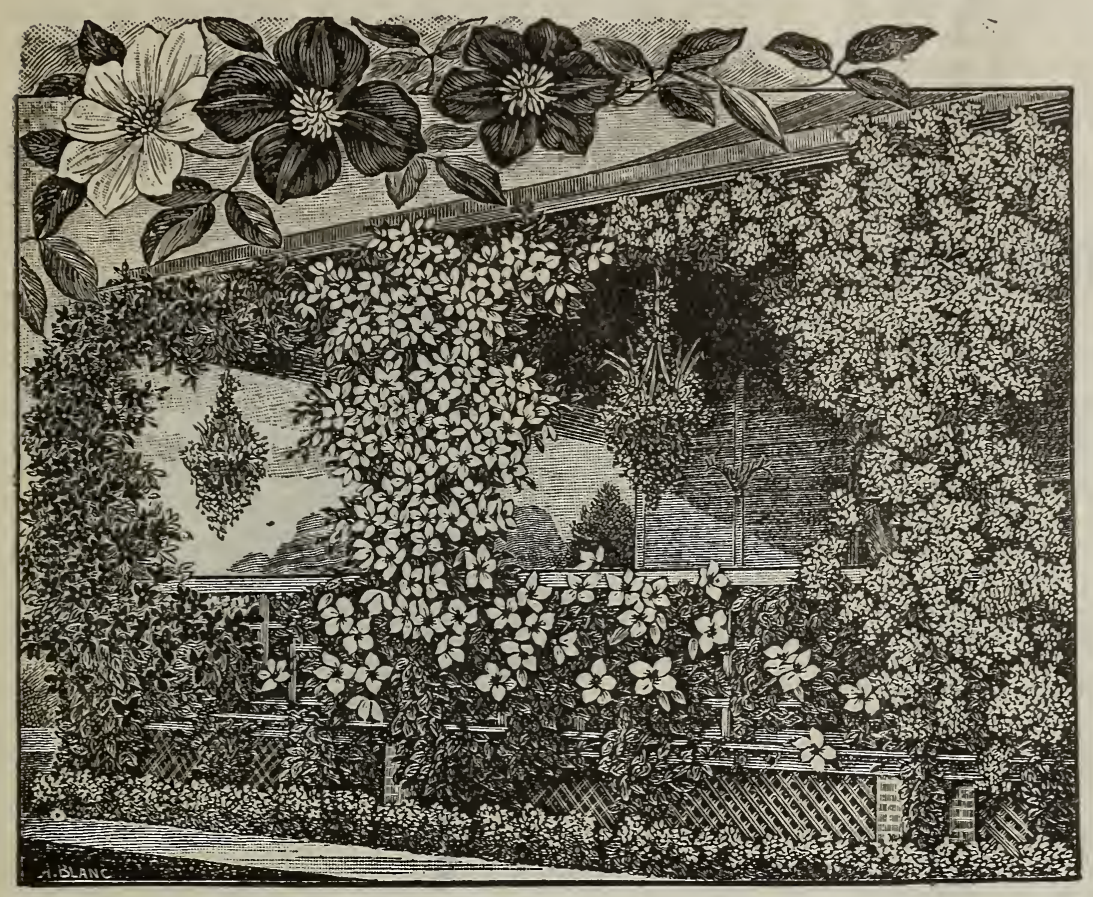

Clematis Jackmanni.

Clematis Henryi.

\section{Clematis}

For house fronts or pillar vines, nothing can surpass the Clematis in grandeur and in beauty.

The roots are perfectly hardy, although the tops die down to the ground every fall. In planting the roots the ground should be dug very deep.

The roots we offer are all three years old.

Jackmanni-Probably the most beautiful climber in cultivation, with rich, deep, velvety purple flowers. Three-year-old roots, each, 75c; postpaid, 90c.

Gypsy Queen-One of the finest; a strong grower, free bloomer, blossom purple with red tinge. Each, $75 \mathrm{c}$; postpaid, 90c.

Coccinea-Rich, scarlet tubular flowers. Each, 75c.

Henryi-A strong grower; flowers from 4 to 5 inches in diameter and pure white. Three-year-old roots, each, $65 \mathrm{c}$; postpaid, $80 \mathrm{c}$.

Paniculata-This is a valuable Japanese introduction, one of the finest additions to our list of hardy climbers; a very strong vigorous plant and as easily grown as the common. Each, 35c; postpaid, 40c. One each of five varieties of Clematis, $\$ 2.50$, not prepaid.

Bignonia Grandiflora (Trumpet Vine)-Clings to bark or walls. Fern-like foliage, orange scarlet; trumpetshaped flowers. Price, $25 \mathrm{c}$ each.

ARISTOLOCHIA RADICANS (Dutchman's Pipe) - Hardy vine of rapid growth, large heart-shaped leaves and brown flowers, resembling a small pipe. Each, 50c.

\section{Cinnamon Vine}

From the Oriental land, is one of the most charming climbers, and will quickly surround your arbor, window or veranda with a wonderful profusion of vines, covered with handsome, glossy, heart-shaped leaves and sweet- scented flowers, making it a perfect bower of beauty-thriving everywhere, and once planted will grow for many years. The vines often run 25 to 40 feet. Beautiful, hardy, entrancingly fragrant. Grows in shade or sun, wet or dry. No insects ever trouble, no winter harms. Once planted will grow a lifetime. Large roots, $10 \mathrm{c}$ each; 3 for $25 \mathrm{c}$; doz., $75 \mathrm{c}$, postpaid.

AMPELOPSIS VEITCHII (Boston Ivy)-One of the finest climbers for covering walls, as it clings firmly to the smoothest surface, covering it smoothly with overlapping foliage. $25 \mathrm{c}$ each, 3 for $60 \mathrm{c}$, not prepaid.

\section{Honeysuckle}

Halleana-White, sweet scented. $35 \mathrm{c}$ each, 3 for $\$ 1.00$.

Scarlet Trumpet-Sweet scented. $35 \mathrm{c}$ each, 3 for $\$ 1.00$.

Monthly Fragrant-Red and yellow, very fragrant; blooms all summer. Leaves tinged with reddish color. 35c each, 3 for $\$ 1.00$.

QUINQUEFOLIA (Virginia Creeper)-A native vine, handsome foliage, turning to bright crimson in fall. $25 \mathrm{c}$ each, 3 for $60 \mathrm{c}$, not prepaid.

WISTARIA-Beautiful climber of Clematis Paniculata. rapid growth, producing long pendulous clusters of pale purple flowers. Is very hardy. Price, each, 50c. 


\section{BLAGKBERRIES}

Early Harvest-One of the most valuable where earliness is sought, being one of the first to ripen. Good shipping qualities; compact dwarf grower, enormous bearer; fruits medium size, black and of excellent quality. Price, per $100, \$ 1.25$; per $500, \$ 6.00$; per $1,000, \$ 10.50$; by express, not prepaid.

Snyder-Extremely hardy, enormously productive, medium size; no hard, sour core; only half as many thorns as a Lawton or Kittatinny; most prolific blackberry grown. Price same as early Harvest.

Taylor-Berries of fine flavor; larger than Snyder. Canes of vigorous growth, iron-clad hardiness and wonderfully prolific; ripens late. $10 \mathrm{c}$ each; dozen, $75 \mathrm{c} ; \mathbf{5 0}$, $\$ 2.25 ; 100, \$ 4.00$.

\section{RASPBERRIES}

Kansas (Blackcap) -Best home and market berry. Price, doz., $50 \mathrm{c}$; $\$ 1.25$ per 100 ; per $500, \$ 4.50$; per $1,000, \$ 8.00$; by express, not prepaid.

Cumberland-The largest of all blackcaps. A healthy, vigorous grower, throwing up stout, stocky, well-branched canes that produce immense crops of magnificent berries. Fruit very large, firm; quality about same as Gregg; keeps and ships as well as any of the blacks. Each, 10c; dozen, $75 \mathrm{c} ; 50, \$ 2.25 ; 100, \$ 4.00$.

Gregg-The leading late blackcap; fruit large, meaty and of fine flavor. Dozen, $50 \mathrm{c} ; 100, \$ 1.25$; per $500, \$ 4.50$; per $1,000, \$ 8.00$.

Haymaker-The Haymaker is a purple cap; fruit large, solid, a fine keeper. Dozen, 50c; $100, \$ 1.25$; per 500, $\$ 4.50$; per 1,000, $\$ 8.00$.

Cuthbert, or Queen of the Market (Red)-A remarkably strong and hardy variety; very large; rich crimson. Dozen, 50c; 100, $\$ 1.25$; per $500, \$ 4.50$; per $1,000, \$ 8.00$.

Miller (Red)-Extremely hardy, very productive; one of the earliest to ripen; attractive color. Doz., 50c; 100, $\$ 1.25$; per 500, $\$ 4.50$; per $1,000, \$ 8.00$.

Loudon (Red)-Berries large, good color; excellent quality; very productive. Dozen, 50c; 100, $\$ 1.25$; per 500, $\$ 4.50$; per 1,000, $\$ 8.00$.

\section{STRAWBERRIES}

Culture-To produce large fruit, keep in hills, pinching runners as soon as they appear. In the winter, a covering of straw or leaves will protect the plants. Do not cover them, however, until the ground is frozen, and then not so deep as to smother them. Remove covering before growth starts in the spring. Plant in rows, 3 to

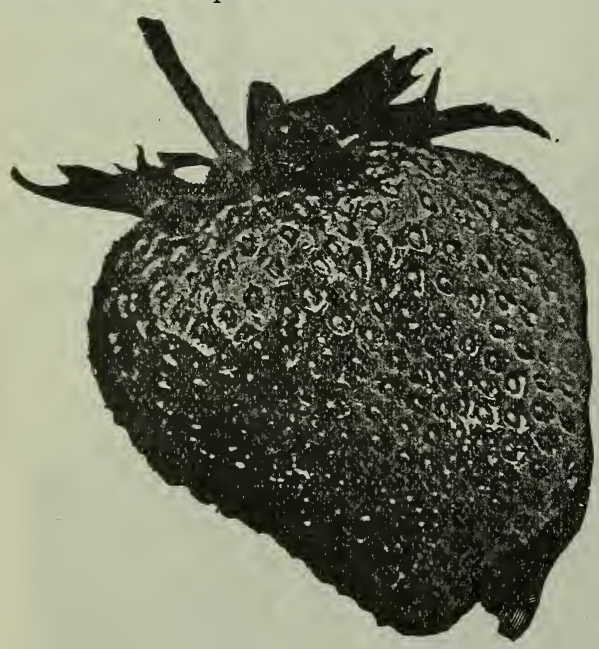
$3 \mathrm{~T} / 2$ feet apart, 15 to 18 inches in a row. Dip plants in water as soon as received, and bury the roots in moist, shady ground until you are ready to set them out; neglect for an hour or so is often fatal.

Price: 25 for $50 \mathrm{c}$; $\$ 1.00$ per 100 , prepaid. Not prepaid, $75 \mathrm{c}$ per 100 ; per $500, \$ 2.50$; per $1,000, \$ 4.50$; per 5,000 lots, $\$ 4.00$ per 1,000 . These to come by express. Do not ask us to ship by freight. Delivered at express office, Kansas City, Mo.

Brandywine-A large, handsome and productive berry of excellent quality; dark, glossy red; extra good sort for all purposes.

Bubach-A leading market sort; more of this variety being used than any other; large and uniform in size, fine form and color.

Senator Duriap-Fruit good size; regular form. Beautiful bright red, glossy, firm; splendid keeper and shipper; excellent quality; ripens early and continues a long time.

Captain Jack-A most vigorous grower, healthy and productive, berries large, handsome and solid.

Gandy-A reliable late variety; berries bright crimson, very uniform in size and shape; large and firm; plants vigorous and healthy.

Warfield-A reliable market sort; good flavor; vigorous and productive; very early.

We can also supply the following standard sorts: Aroma, Excelsior, Crescent, Monitor and Windsor Chief.

\section{GOOSEBERRIES}

Plant in good, rich soil and give a liberal dressing of manure every season. Regular pruning every year is essential for the production of fine fruit.

Downing-Large, handsome, pale green and of splendid quality for both cooking and table use; bush a vig- orous grower and usually free from mildew. 15c each; $\$ 1.50$ per dozen; $50, \$ 5.00$.

Houghton's-Small to medium; round, oval; pale red, sweet, tender, very good; plants spreading; shoots slender, enormously productive. $10 \mathrm{c}$ each; $\$ 1.00$ per dozen; $50, \$ 4.00 ; 100, \$ 7.00$. 


\section{FRUIT TREES}

Strong, Stocky Trees, packed and shipped by freight or express, delivered f. o. b. cars Kansas City, Mo., or express office, not prepaid.

\section{Summer Apples-2 Years Old, each 50c}

Early Harvest-Medium to large; round; bright straw color; flesh white, tender, juicy, crisp, with rich flavor. July.

Cooper's Early White-Very large, round, pale yellow, with faint biush; flesh white, crisp. August 1.

Carolina (Red June)-Medium size; red; flesh white, tender, juicy; an abundant bearer. Last of June.

\section{Autumn Apples-2 Years Old, each 50c}

Maiden's Blush-Large, regular, smooth, with fine, evenly shaded red cheek or blush on a clear yellow ground; flesh white. August and September.

Rambo-Medium; yellowish, streaked with dull red; mild, tender, productive. September to November.

\section{Winter Apples-each 50c}

Grimes Golden-Medium to large size; yellow; vigorous and productive.

Gano-Fruit bright red, on yellow ground; no stripes: large, oblong, surface smooth; prolific bearer.

Huntsman's Favorite-Very large, golden yellow, with bright red cheek; nearly sweet; fine flavor.

Jonathan-Fruit medium; round; skin yellow, nearly covered with dark red; fine grained, very tender and finely flavored.

Winesap-Medium; dark red, sub-acid; abundant bearer; a favorite market variety.

\section{Crab Apples-each 50c}

Hyslop-Almost as large and as early as the Strawberry apple; deep crimson.

Large Red Siberian Crab-About an inch in diameter; yellow, scarlet check; bears young.

\section{Peaches -4 to 6 Feet, each 50c}

Alexander Early (Cling)-Good quality; fine flavor; very early.

Champion (Freestone)-Very hardy; matures about August 15th.

Elberta (Freestone)-Finest yellow freestone in cultivation; family favorite; last of July.

Mountain Rose-July.

Old Mixon (Cling)-Pale yellow; August.

Old Mixon (Freestone)-Pale yellow; August.

Crawford's Early-Fruit large, oblong, yellow with red cheek; flesh yellow, juicy, sweet, excellent, free; last of July.

\section{Pears-2 Years Old, each 50c}

Wilder's Early-Medium size; greenish yellow.

Duchess d'Angouleme-Very large; greenish yellow; a general favorite; September and October.

Kieffer's Hybrid-Valuable for table and market. September and October.
Bartlett-Large size; very juicy and highly flavored: bears early and abundantly.

Seckel-Small; skin rich yellowish brown when ripe, with a dull red cheek; flcsh very firie grained, sweet and juicy. August and September.

\section{Plums-2 Years Old, each 50c}

Pottawattamie-Very hardy; an immense bearer; fruit yellow, overspread with bright pink; July.

Wild Goose-Rich crimson; July.

Damson-Fruit small, oval; skin purple, flesh melting and juicy, rather tart. September.

\section{Cherries-2 Years Old, each 50c}

English Morello-Medium to large; blackish red; July. Early Richmond-Medium size; dark red; June. Large Montmorency-Large, red cherry; July.

\section{Grapes}

Campbell's Early-One year old, $15 \mathrm{c}$; six for $75 \mathrm{c}$; $\$ 1.50$ per dozen. Two-year-old, $25 \mathrm{c} ; 6$ for $\$ 1.25 ; \$ 2.50$ per aczen.

Concord-One-year-old, 8c; 6 for $45 \mathrm{c} ; 75 \mathrm{c}$ per dozen. Two-year-old, $15 \mathrm{c} ; 6$ for $50 \mathrm{c}$; $\$ 1.00$ per dozen.

Moore's Early-One-year-old, 10c; 6 for 50c; $\$ 1.00$ per dozen. Two-year-old, $15 \mathrm{c} ; 6$ for $75 \mathrm{c} ; \$ 1.50$ dozen.

Niagara-One of the very best white grapes grown, sweet, delicious ilavor; vigorous and productive. Oneyear-old, $15 \mathrm{c}$ each; 6 for $75 \mathrm{c}$; $\$ 1.25$ per dozen.

Catawba (Red Grape)-Skin dark red when ripe; sweet, rich flavor; very productive. One-year-old, 15c each; 6 for $75 \mathrm{c}$; $\$ 1.25$ per dozen.

\section{Currants-2 Years Old}

Good two-year-oli strong plants, $15 \mathrm{c}$ each; $\$ 1.25$ per dozen; $\$ 5.00$ per 100.

Large Cherry-The largest of all the red currants; berries sometimes measure half an inch in diameter; bushes are short; very vigorous; the kind to plant in the city.

\section{PEDIGREED SEED CORN}

Is a Money Maker for the Farmer. Grow it and Increase Your Yield Five to Twenty Bushels Per Acre.

We Have Catalogued all the Varieties of Seeds Usually Demanded. If There is any Seed or Article You Want and it is in Our Line, Write Us for Prices. 


\section{FIELD SEEDS}

While we have for a great number of years handled a complete line of field seeds, we are this season in better shape to take care of your orders and make prompt shipment than ever before. Larger warehouse facilities give us the opportunity to buy in larger quantities than heretofore at more reasonable figures, allow-

\section{PEDIGREED}

We are offering this year for the first time a few of the best varieties of corn which we have bred up and made pure. The value of pedigreed seed corn is well known, and we need not mention that matter further, except to say that we can offer you seed that will increase your yield per acre from five to twenty bushels. That alone is sufficient reason for a man to plant pure pedigreed stock.

The fact that corn when mixed with other varieties loses not only its identity but its yielding power is an accepted fact by our corn men who have made this a study. Low vitality means poor yield.

Corn is a plant which is not only cross fertilized, but will also fertilize itself. In other words your corn, however strong, can be weakened by your neighbor's corn across the way; or if his corn is stronger than yours, yours will be benefited, while his will be weakened. These are facts. Another is that your corn will inbreed, the pollen from the stalk falling upon the silk of the ear on this stalk. This we know to be wrong, but in the open field we cannot prevent it, and for that reason it is necessary to change your seed every few years in order to get the pure strain practically free from cross and inbreeding. A farmer under ordinary circumstances cannot breed or pedigree his own stock of corn. We have therefore taken up this line and have been working on it for the past two years.

This season we offer for sale a complete line of pedi-

ing us to offer you the best grade of seed at reasonable prices.

If you require further descriptions of any variety of seed or wish samples, we will be most pleased to send same to you.

We offer only the best, and your orders will have our careful attention. All prices made f. o. b. Kansas City.

\section{SEED CORN}

greed seed corn. These varieties are well known and grown by all the best farmers in the country. We have not tried to get anything new, except one variety which for four years we have watched and bred up. No one grows it except that which is grown in our breeding plots. This corn is the Gold Nugget, a long-grained, small-cob yellow corn, ears cylindrical. Well filled at both butt and tip. The kernels are extra long, while the cob is very small and bright red.

Gold Nugget is a big yielder. We have found this to be true in every test we have made. The first half acre we put out yielded 60 bushels, 120 to the acre.

Corn breeding today is common sense, coupled with a small amount of science. Completing the breeding work is the most difficult part and that is generally left to the man who makes this his only work. Beginning with a single ear and taking the successive steps is reasonably easy, but to complete the test of fertilization, cross breeding, capping and hand pollination is extremely difficult and must be most carefully done.

We are the first to take up this line of work on an extensive scale in this section of the country, and are, therefore, in position to offer you the first home-grown pedigreed seed corn-corn that is acclimated and that will produce a fine crop the first season. A description of the different varieties will be found on the following pages.

\section{Golden Beauty}

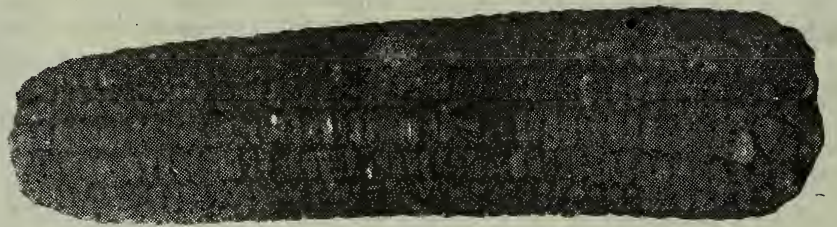

Golden Beauty.

This variety of yellow corn has been very popular in Missouri for many years and we obtained, a few years ago, a fine strain from which we have produced the stock of seed we now offer for sale.

This corn resembles the Leaming somewhat in color, but the kernel is broad and deep while the cob is a bright red, medium in size. The corn is carried out well at the butt and tip, giving the ear a cylindrical appearance. The rows are very straight and carry well to the ends. Matures medium early and is one of the biggest yielders we know about.

We have a small stock of this seed on hand and advise you to order early.

Ear Corn in bushel crates, $\$ 2.50$ per bushel.

Price, $\$ 2.00$ per bushel, shelled. Bags Free.

\section{Reid's Yellow Dent}

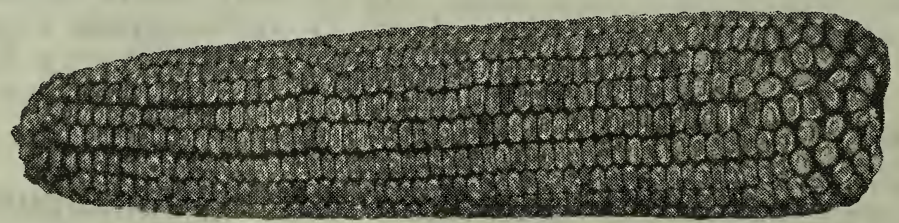

Yellow Dent.

This corn was originated in 1823 by J. L. Reid, and since that time it has been the staple and leading vari- ety. There have been many who thought they had something better, but have generally come back to the 
"old reliable." We have a selected pedigreed strain of this corn which we offer for sale.

Ears average 8 to 11 inches in length from 18 to 22 rows of kernels, having good deep color. The cob is a deep red, entirely covered by corn, which is one of the most essential features of this variety. There is no waste room on an ear of Yellow Dent. The shank is small, very easy to shuck. It is medium early in maturing, taking about 110 days in Kansas and Missouri and 100 to 105 days south of these two states. The stalk is heavy below the ear, making the corn the most wind-resistant known. Altogether this corn is probably the best known and best yielding variety. Plant it this season and if you have been growing it, change your seed, get some of our pedigreed stock. Order now. We will ship immediately unless otherwise ordered.

Ear Corn in bushel crates, $\$ 2.50$ per bushel.

Price, $\$ 2.00$ per bushel, shelled; Bags Free.

\section{Leaming}

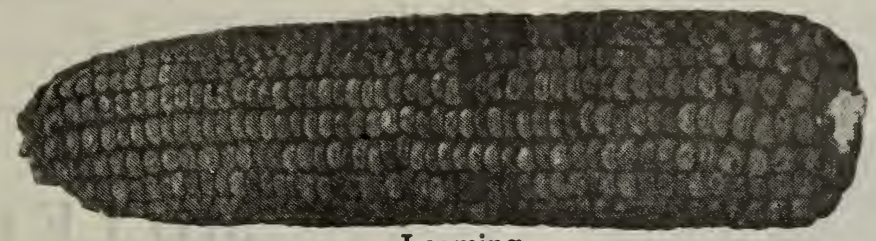

Leaming.

This variety of corn was originated in 1828 by J. S. Leaming and for many years was the leading corn in Ohio, when it was brought west. Illinois cattle men used it in large quantities and found it to be the best feed of any corn known. We brought some of the pure stock from the north and have bred it up in Missouri, making it thoroughly acclimated to your section of the country.

This season we offer you a fine strain of Leaming corn for seed, pure and pedigreed stock. For the cattle feeder there is no better corn on the market, because of its percentage of oil and protein. The ear measures about 8 to 11 inches in length, having a large butt, tapering well down to the tip. The kernels are deep, with rich yellow coloring. Rows carry well to both ends.

Rather rough in seed coat, but this feature makes it more attractive to the cattle. For ensilage no other corn can equal this in value. The big dairy men of the north use nothing else in their silos.

Kernels are deep and evenly situated on a red cob, rows cary well to the ends, producing a big percentage of shelled corn to the ear. Matures in 100 to 110 days and produces very heavy foliage and strong stalk.

Ear Corn in bushel crates, $\$ 2.50$ per bushel.

Price, $\$ 2.00$ per bushel, shelled; Bags Free.

\section{Gold Nugget}

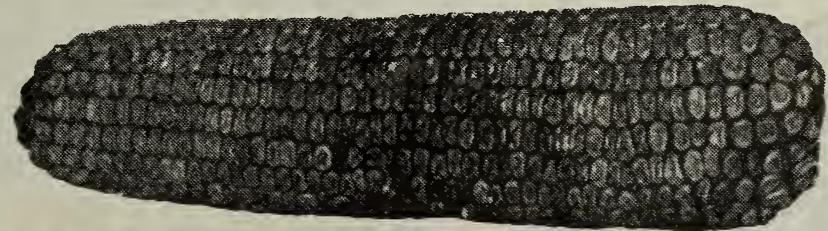

Gold Nugget.

This corn is practically an unknown variety and has been grown only by a few who happen to be neighbors of the man who first introduced this seed. The value of Gold Nugget corn is unknown except to us who have worked with it and seen it produce. We will have a small supply of this seed which was taken from one of our test fields, and this we offer for sale this spring.

Harnden's Gold Nugget is a yellow corn of a bright gold color. The kernels are very long, the longest we have ever seen, and the cob small and deep red. The ear averages about $61 / 2$ to 8 inches in length, while there are from 16 to 22 rows on the cob. This corn will shell out 88 to 90 per cent. The feeding value of this variety is very great, for the kernels contain a large amount of oil and protein. The depth of kernel guarantees this, and the man who feeds cattle or hogs knows what it means to feed oil and protein.

\section{Boone County White}

The king of white corn. No one has ever found a white corn to yield, year in and year out, with this variety. It stands the drouth better and is more windresistant than any white corn we know about. It is also the finest milling corn we know of-which often brings a premium over the yellow corn.

The general appearance of this corn is pure white, with medium large cob and long, deep, rough kernels. The ears will average 8 to 11 inches in length, being full and cylindrical in shape. There is no waste room on an years.
The yielding quality of this corn has been wonderful. The first half acre we put out yielded, by actual weight, 60 bushels, 120 bushels to the acre. This was our test field. From this we put out ten acres of purebred stock and have on hand a small amount of this seed to sell.

Don't fail to order some of this seed corn. If you could see the corn grow, with its deep green foliage, very heavy stalk and abundance of fodder, to say nothing of the ear itself, you would plant nothing else this spring. As our supply is low, send your order as soon as possible and if you wish we will hold your shipment for you.

Ear Corn in bushel crates, $\$ 2.50$ per bushel.

Price, $\$ 2.00$ per bushel, shelled; Bags Free.

(We cannot sell more than 15 bushels to any one customer.)

ear of Boone County White.

We are fortunate in having a fairly good supply of this variety, which we offer to our patrons. This seed has been thoroughly tested and has germinated $941 / 2$ per cent. Under the past season's growing conditions this is exceptionally high. This stock has also been bred from a pure strain which we have worked on for two

Ear Corn in bushel crates, $\$ 2.50$ per bushel.

Price, shelled, $\$ 2.00$ per bushel; Bags Free. 


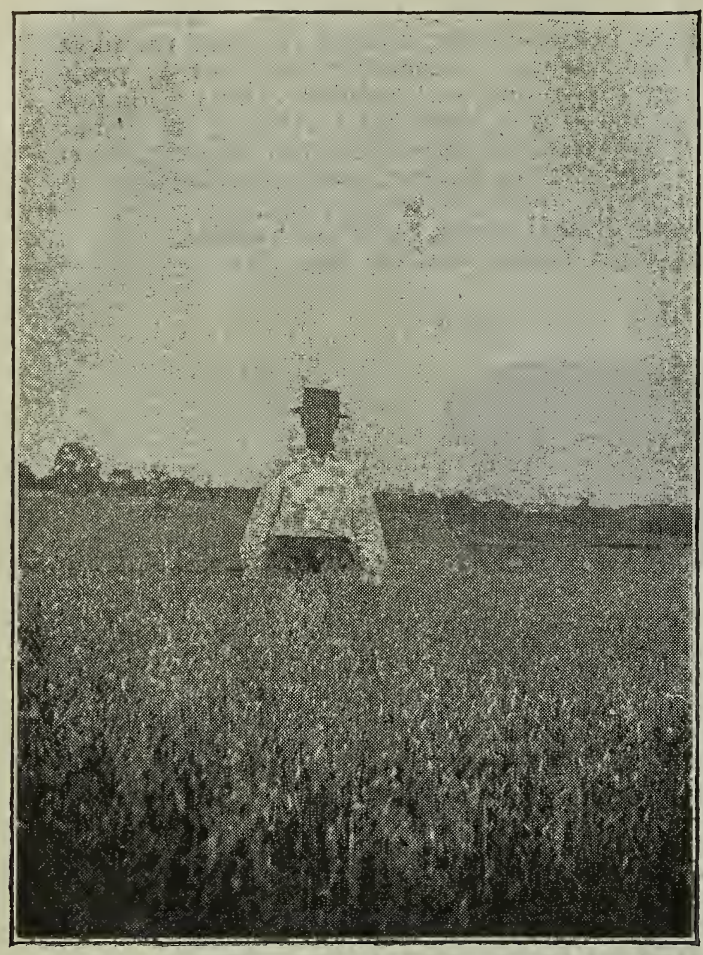

Field of Lincoln 60-Day Oats. Yield $52 \mathrm{x} / 2$ Bushels to the Acre.

\section{ALFALFA}

To describe this plant, or state its many different uses, is a waste of time. We all know how valuable this hay crop is, what a soil builder and fertilizer its roots are, and how nitrogen from the air is absorbed and permeates the roots, finally going out into the soil around each plant. Alfalfa is money, and its uses manifold.

Sow in spring or fall on ground well drained. Put your seed bed in extra fine condition. Buy clean seed.

We offer you pure non-irrigated Alfalfa seed, free from noxious weeds, withered grains or dead seeds. On board cars here at the market figure. Write for samples and prices. Bags extra.

\section{ALSYKE CLOVER}

Alsyke Clover is one of the best forage and hay crops known. A little hardier and tougher than the regular red clover, with which we are more familiar.

Pure seed, free from all noxious weeds. Prices on application. Cotton seamless bags, 22c extra.

\section{BARLEY}

We have both the Bearded and Beardless on hand. When in the market, send to us for samples and prices.

\section{Hildreth's Yellow Dent}

This corn is one of the most popular varieties grown in Kansas, Missouri and Oklahoma. It grows a large ear, with kernels carried well out to the ends. The cob is medium large and a bright red. The kernels are deep and set very close together, which means there is no waste room on an ear of Hildreth's.

The seed coat is medium rough, while the general color is a deep golden yellow. This particular strain of Hildreth's was grown by one of the best corn men in the State of Kansas. It is pure and pedigreed stock; well selected and graded.

We can ship either on the ear or shelled.

Prices: $\$ 2.50$ per bushel on the ear; $\$ 2.00$ per bushel, shelled.

\section{MILLET}

Last season Millet was very high and up to the the present time we cannot tell just what the market will be. Write us for prices when you need seed. We will carry German, Siberian and common Millet.

\section{LINCOLN 60-DAY OATS}

We have in these Oats the earliest variety known in straight unmixed White Oats. These will be ready to cut three weeks ahead of the ordinary oats which have been used in your neighborhood. This is very often advantageous, for a man may not want all his oats to ripen at the same time. Also it is a money-maker for these oats are fine to sow over frozen or drowned-out wheat fields. Disc your land and then drill or broadcast two bushels to the acre and you will have a fine crop of early oats. Prices: 1 to 5 bushels, $\$ 1.00 ; 5$ to 15 bushels, 95c; 15 to 50 bushels, 85c. Bags Free.

\section{RED TEXAS OATS}

We have an extra good grade of Texas Red RustProof Oats, native grown. These oats are heavy and will weigh about 36 to 37 pounds to the bushel, clean and free from withered grains or chaff.

This variety of oats has been a popular one for many years and no one can make a mistake in sowing them. Prices: In lots 1 to 5 bushels, $95 \mathrm{c} ; 5$ to 20 bushels at 85c. Bags Free.

Five bushels to a bag unless otherwise ordered.

\section{COW PEAS}

We have on hand a fine grade of Cow Peas, both the New Era and Whippoorwill. This is new crop seed and very fine. We offer these at present market prices. Write us for quotations. Sow a few field peas; it is good for your land and your hogs.
Evergreen Grass Mixture $\begin{aligned} & \text { We sell on y } \\ & \text { the best grade }\end{aligned}$ -the other kind doesn't pay. Sow the best-it's the cheapest. Prices as follows: One pound, 35 cents; three . ounds, $\$ 1.00$; bushel, $\$ 4.25$. If to go by mail add one-half cent per ounce.
Tell Your Friends About Our Paper The Kansas City Seedsman We Will Send it to Them if You Will Send Us Their Names 


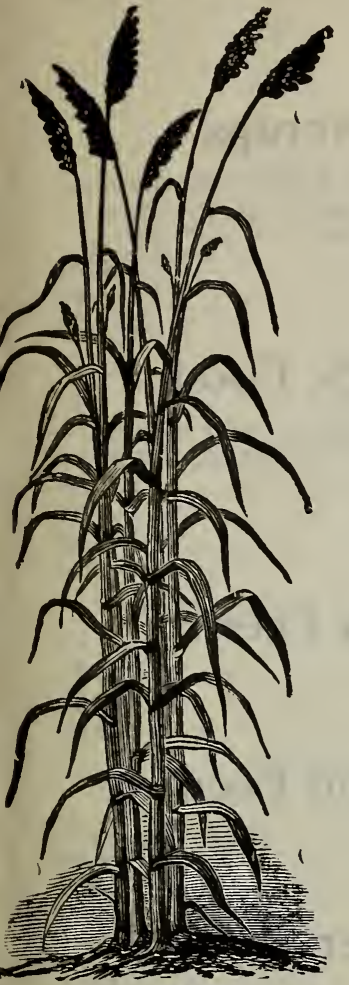

Cane.

\section{DWARF ESSEX RAPE}

Every farmer who has hogs, sheep or young stock should grow a little Rape each year. A feed lot in Rape will give you green feed during the summer months, and you will be more than repaid. It is often sowed in oat fields, which makes a fine fall pasture for sheep. Sow six pounds to the acre. Price, $\$ 6.00$ per 100 pounds.

\section{RYE}

We handle the pure Winter Rye and when you are in the market next summer or fall, don't forget to write for prices.

\section{SPELTZ OR EMMER}

A hardy, productive grain; grows like rye and matures as early as barley; tough and hardy, stands drouth, and for an all around feed for any fowl or beast it cannot be excelled. Write for prices.

\section{TIMOTHY}

Timothy seed this season is very high, and our stock is small. Weather conditions were against a good crop last year, and this, combined with a big demand. has caused high prices. The seed we have on hand is of exceptionally high grade, the safest and surest seed to buy.

Our seed was taken direct from thresher and bagged, insuring the seed from being bin-burned. This guarantees you a good stand, for bin-burned seed will not germinate and is the direct cause for many poor yields.

We offer you fancy recleaned Timothy seed at per bushel, f. o. b. Kansas City. Bags extra at 22 cents.

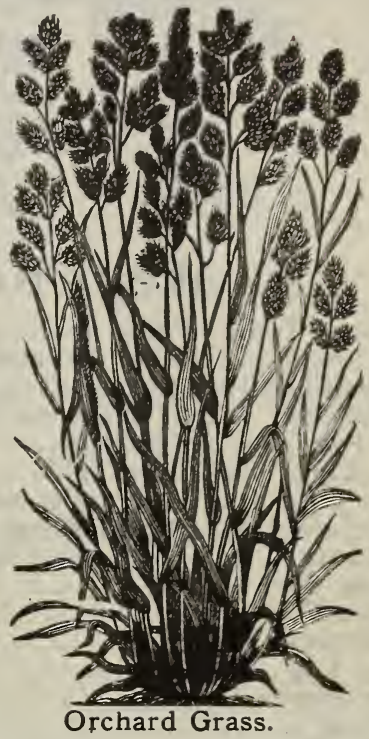

\section{BROOM CORN}

Oklahoma Dwarf-This variety is probably the most popular and the best. The brush is more uniform and in harvesting is pulled rather than broken. We can recommend this corn and know full well that no other variety will give you the satisfaction. Write for prices.

Cane, Kaffir, Buckwheat, White Clover, in fact all farm seeds, are carried in stock and prices will be gladly submitted at any time. If you desire samples we will be pleased to send same.

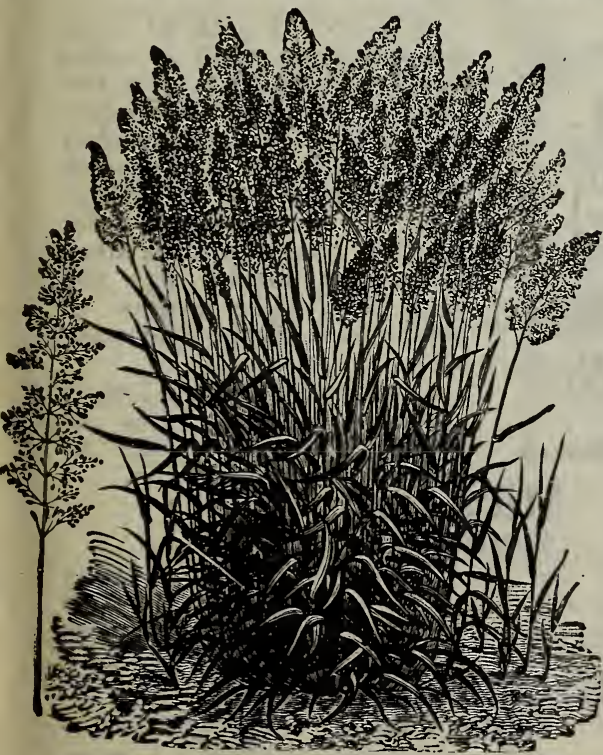

Red Top.

\section{VETCH}

This is a valuable forage plant. Belongs to the pea family, but the vines grow much longer and have more abundant foliage. It is also very valuable as a soil builder as it restores nitrogen. It is an annual, but drops its seeds freely and will come up year after year on the same ground. Sow with oats, barley or rye, etc. It succeeds on almost any soil and should not winter kill.

Sow Vetch in fall. The ground is then covered before winter, which prevents washing. Also sow in April and you can cut in July, the second crop being a fine hoy pasture during the summer. Yields from 10 to 15 tons per acre. Sow 20 pounds to the acre. Prices on application.

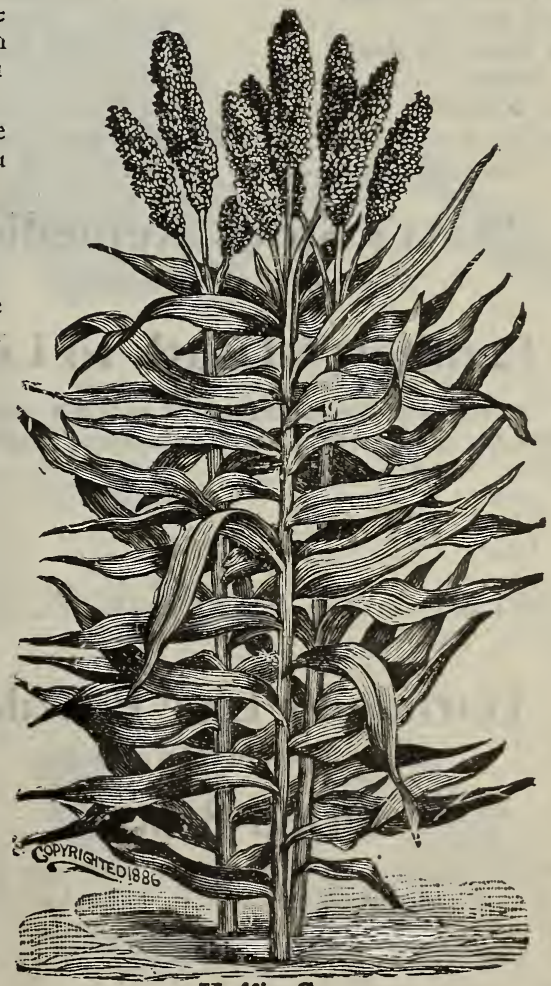

Kaffir Corn. 


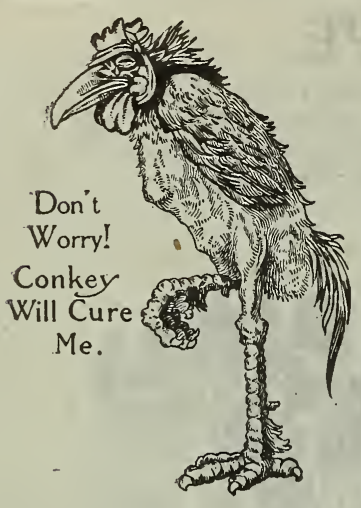

POULTRY

We carry many different kinds of Feed, Louse Killers and Remedies, and try always to keep up with any new goods of superior quality that come out. We have listed such goods as have been tried and found the best, and as fast as other new articles come out, we will put them in stock.

Add one cent per ounce to pay postage if sent by

\section{Conkey's Remedies}

Laying Tonic-Finest tonic for egg production.

ways produces results. 25c and 50c per package.

Gape Cure-Positive cure for the gapes. Don't delay in ordering. It may come too late to help your chickens. Price, $50 \mathrm{c}$ per package.

Conkey's Roup Cure-This cure is world-wide popular for it has produced results more than any other tonic ever known. 25c, 50c, $\$ 1.00$ per package.

Bronchitis ............................ 50 c Cholera Cure ....................................... $50 \mathrm{c}$ Chicken Pox ........................ 50 c

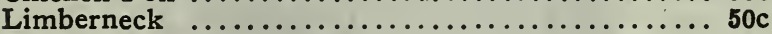

Scaley Leg ......................... 50c

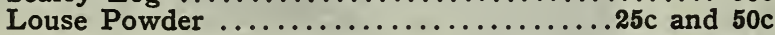

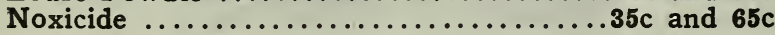

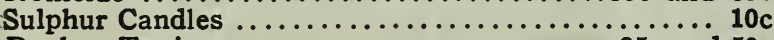

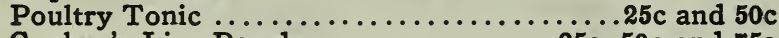
Conkey's Lice Powder................... 50 $\mathrm{c}$ and $75 \mathrm{c}$ Head Lice Ointment............1 oz., 10c; 3 oz., 25c

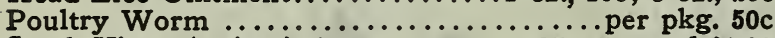
Stock Vigor (3 sizes) ...........25c, 50c and $\$ 1.00$ Pain Lotion ......................... 50c

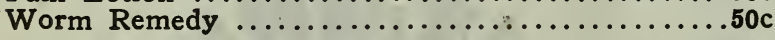

Conkey has a separate individual cure for each disease. Consider the value of this fact alone.

\section{Pratt's Stock Remedies}

We carry a full supply.

\section{Lambert's Death to Lice}

This well-known disinfectant will rid your fowls of all vermin; it is cheap and effective; highly recommended.

5-oz. box ........................ \$0.10

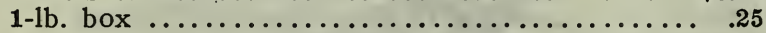

3-1b. box $\ldots \ldots \ldots \ldots \ldots \ldots \ldots \ldots \ldots \ldots \ldots \ldots \ldots \ldots \ldots \ldots, .50$

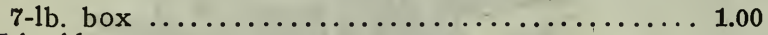

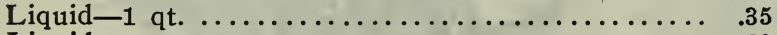

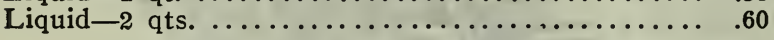

\section{Harnden's Lice Powder}

Sold only in $25 \mathrm{c}$ packages.

\section{Dried Blood}

Greatly relished by fowls; mix with the feed at the rate of one part blood to twenty of meal or shorts.

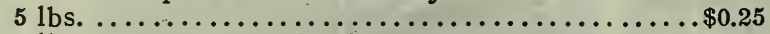

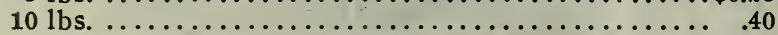

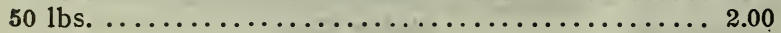

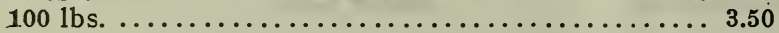

SUPPLIES

\section{Ground Beef Scraps}

Especially prepared for poultry food; not common meat scraps; feed three times a week, at the rate of about a handful to every three birds.

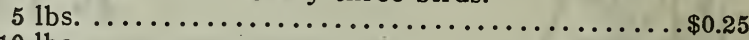

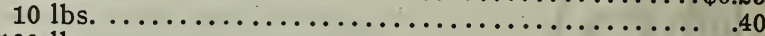

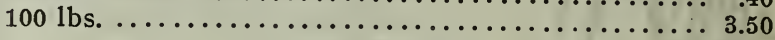

\section{Harnden's Chick Food}

A dry food for small chicks. Samples upon request.

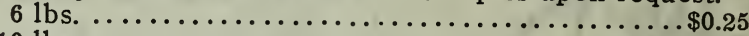

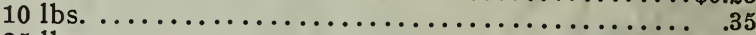

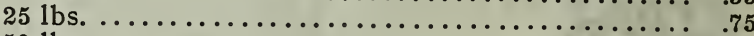

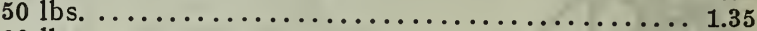

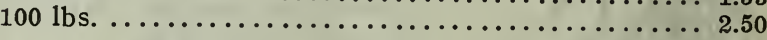

\section{Harnden's Hen Feed}

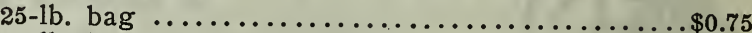

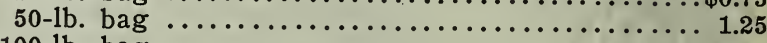

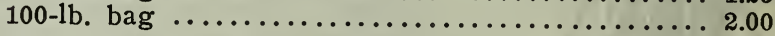

\section{Harnden's Pigeon Feed}

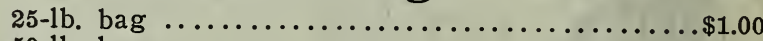

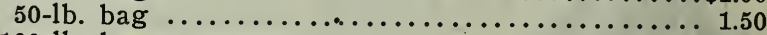

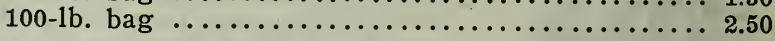

\section{Grushed Oyster Shell}

4 lbs. ........................ $\$ 0.10$

12 lbs. $\ldots \ldots \ldots \ldots \ldots \ldots \ldots \ldots \ldots \ldots \ldots \ldots \ldots \ldots \ldots \ldots, .25$

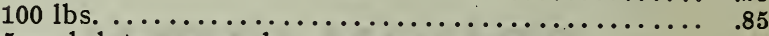

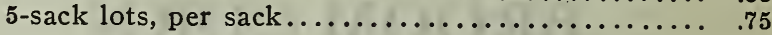

\section{Granite Crystal Grit}

3 lbs. ......................... \$0.10

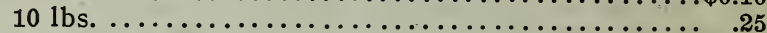

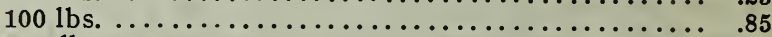

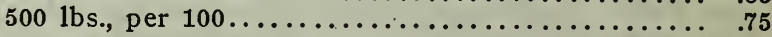

\section{Oyster Shell-Chicken Grit}

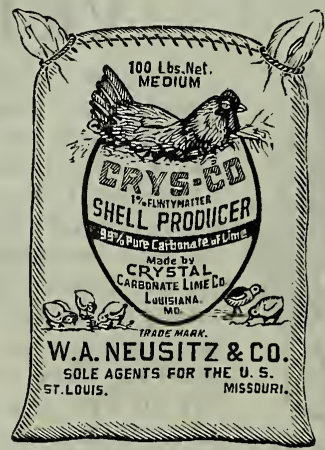

In place of both of these we are using what is called "Crys-Co" which is now recognized as better than either one. The leading poultry raisers all over the country are using it now in preference to any other oyster shell. It comes in three sizes, chick size, broiler size and large size. The medium or broiler size is the one most sold.

4 lbs. ............\$0.10

12 lbs. ............... .25

100 lbs. ............. .85

\section{Mica Grit \\ Coarse or Fine}

4 lbs. .......................... \$0.10

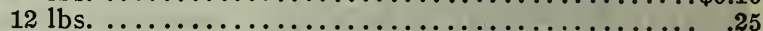

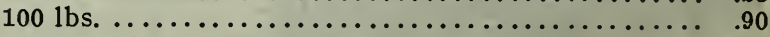

\section{Crushed Bone Fine or Coarse}

4 lbs. ......................... \$0.15

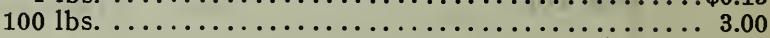




\section{POULTRY SUPPI Charcoal-Granulated \\ An excellent corrective for the fowls, and keeps them

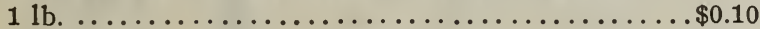

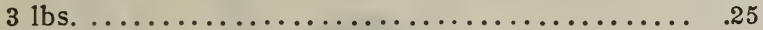

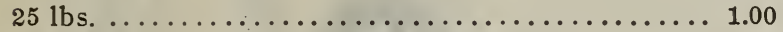
healthy.

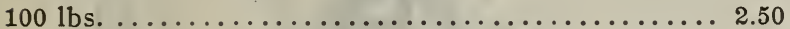

\section{Linseed Meal-Ground Oil Cake}

6 lbs. ................................ $\$ 0.25$

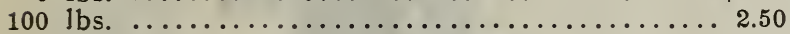

\section{Linseed Meal-Ground Flax Seed}

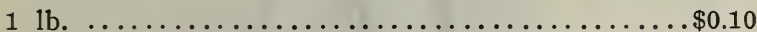

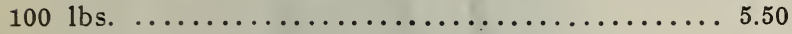

\section{Alfalfa Clover Meal}

This is today considered an absolute necessity, and is the standard "green" for winter egg production.

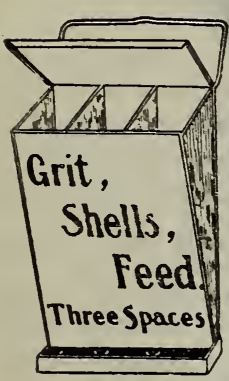

4 lbs. .................. \$0.25

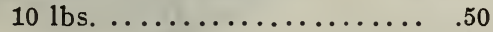

100 lbs. ..................... 2.50

\section{Sanitary Self-Feed- ing Box}

Made of galvanized iron. Saves waste; holds four quarts.

Per dozen ..............\$5.50

Each $\ldots \ldots \ldots \ldots \ldots \ldots \ldots \ldots, .50$

\section{Antiseptic Nest Egg}

The Great Discovery For Ridding Poultry of Vermin

The least trouble to use of any remedy on the market. Only place the egg in the nests, they do the work. Each ............................... \$0.05

Per dozen .............................60

CHINA NEST EGGS-3 for 10c; per dozen, 40 c.

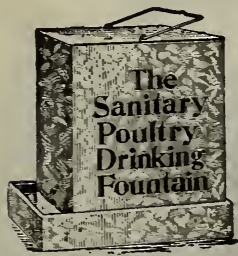

\section{Square Sanitary Drinking Fountain}

Keeps the water clean.

1-gallon

$\$ 0.50$

2-gallon $\ldots \ldots \ldots \ldots \ldots \ldots \ldots . .75$

\section{Star Wall Fountain}

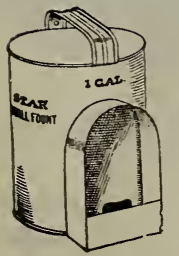

This Fountain is made of best galvanized iron. Will not rust and will last years. Quick and easy to fill and convenient to carry.

$1 \mathrm{qt}$

$\$ 0.30$

2 qt. ........................ 40

1 gal. .......................

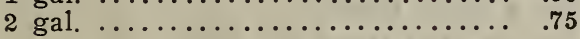

Leg Bands

\section{MT 25 PAT.APPLIEDFOR \\ Champion Leg Band}

"Champion"-See cut. Made of aluminum, adjustable to fit any fowl; in two sizes, 3 -inch and 4-inch.

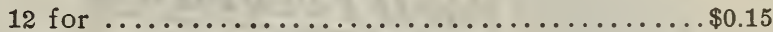

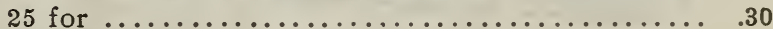

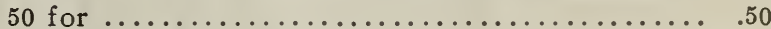

100 for, postpaid..........................90

\section{Champion Poultry Marker} 25c, Postpaid.

\section{Pigeon Bands}

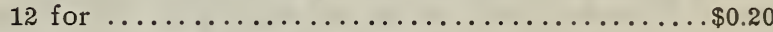

25 for $\ldots \ldots \ldots \ldots \ldots \ldots \ldots \ldots \ldots \ldots \ldots \ldots \ldots \ldots \ldots \ldots . .35$

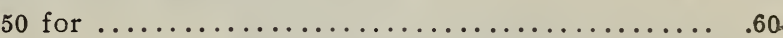

\section{Tennessee Grinding Mill}

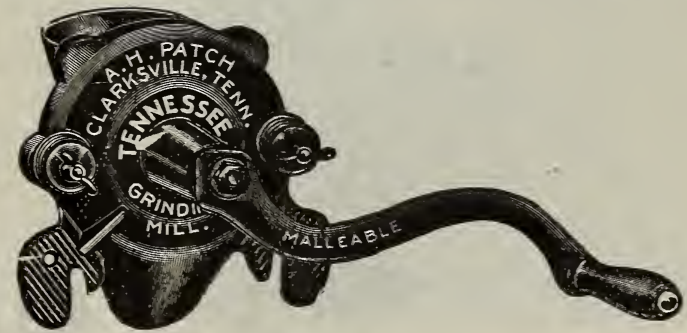

Above cut gives an idea of a cheap and handy grinding mill for farm and family use. It is readily taken apart for cleaning or oiling, without the use of any tools. Easily adjusted for fine or coarse grinding of wheat, corn or other dry grains. Weight, complete, 14 pounds. Price, $\$ 2.50$.

\section{A Non-Freezing Sanitary Fountain}

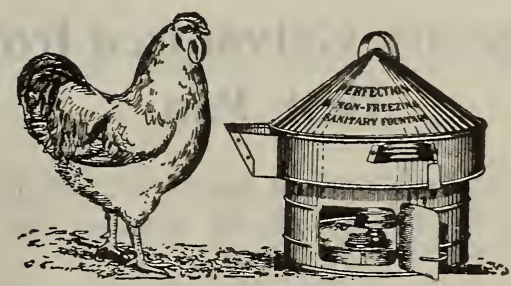

This fountain has been on the market three years, giving perfect satisfaction. 2-gal. size, single cup, $\$ 2.50$. 


\section{POULTRY SUPPLIES-Continued}

\section{X. L. Wall Feed Trough}

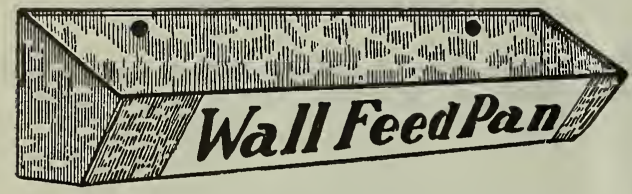

This trough is made of galvanized iron in five sizes. No one raising chickens should be without them. Just the thing for mash feeding. Also used for water and dry feeding.

No. 012 inches long, $21 / 2$ inches deep; price..... $\$ 0.20$ No. 118 inches long, $3 \frac{1}{2}$ inches deep; price..... .25 No. 224 inches long, $31 / 2$ inches deep; price..... .30 No. 330 inches long, $3 \frac{1}{2}$ inches deep; price..... .35 No. 445 inches long, $3 \frac{1}{2}$ inches deep; price..... .50

\section{I._X. L. Dry Food Hopper}

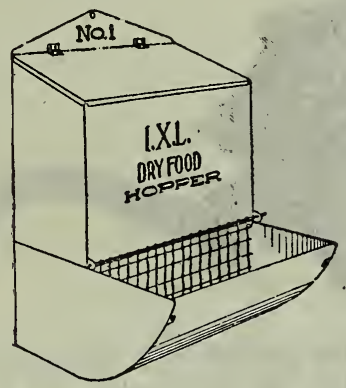

Dry feeding has come to stay, as it is the most practical way to feed poultry. Made of galvanized iron and with proper care will last indefinitely.

No. 1

No. 2

\section{Pigeon's Galvanized Iron Bath Pan}

A necessary article in any pigeon loft. Made in three sizes: No. 1, large enough for 12 pairs; No. 2 for 20 pairs; No. 3 for 25 to 30 pairs.

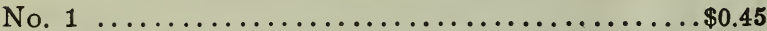

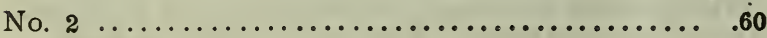

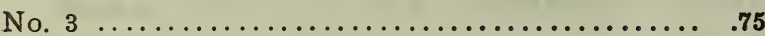

\section{Humphrey's Glover Cutter}

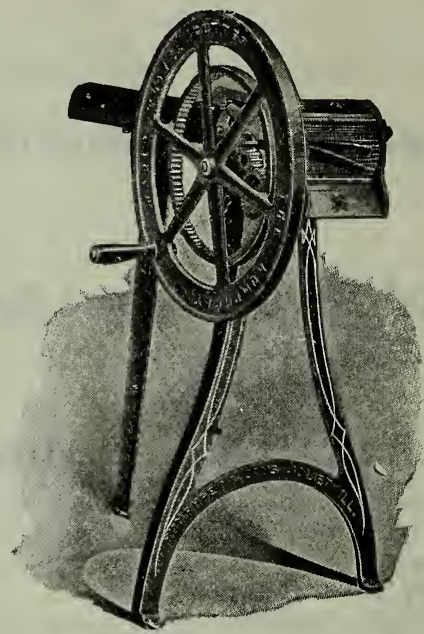

Humphrey's Clover Cutter

See Cut. Price, $\$ 11.00$.

A first-class machine, made of iron and steel. Cuts clover fine or coarse.

\section{Humphrey's Bone Cutter}

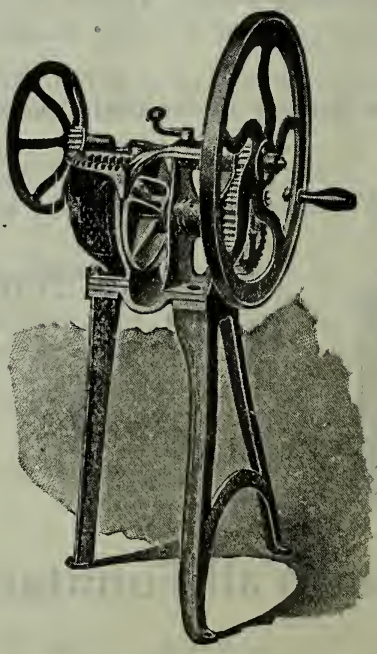

Humphrey's Bone Cutter

The only bone cutters that are practical vegetable and kraut cutters.

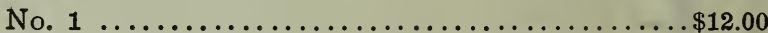

No. 2 Small Power....................... 14.50

No. $2 \mathrm{x} / 2$ Half Hand and Power.............. 16.00 


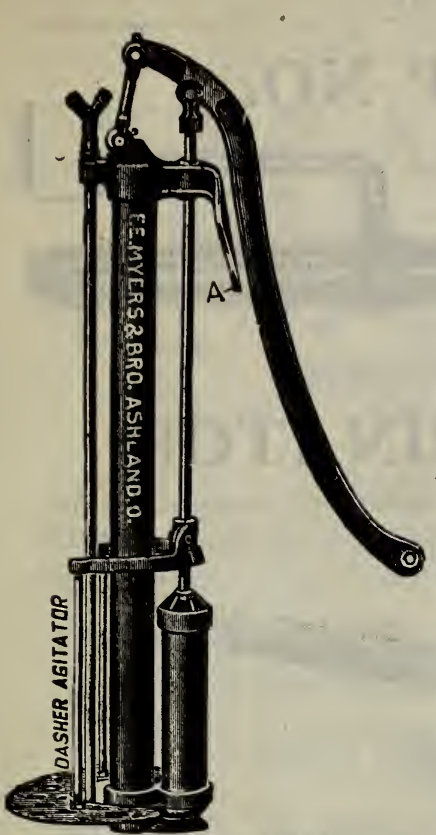

\section{LIGHTNING COMPRESSED-AIR SPRAY PUMP No. 25}

The Lightning Barrel Spray Pump has great capacity, and will throw a solid, continuous stream or any size spray desired. The air is compressed into the air chamber, thereby giving an unbroken stream; with one stroke of the pump handle the pressure is retained so that the working of the pump handle is very slow, and yet giving a great force of water, which is accomplished by the compressed air chamber, making it the most rapid spray pump made.

The agitator thoroughly stirs the liquids and prevents it from settling. It is provided with a brass strainer in the bottom of the suction barrel. The suction barrel is made of heavy brass, ground together so that all parts fit absolutely air tight, and will not corrode or rust out. This pump is easily and quickly adjusted to any barrel, provided with means of bolting to the staves of the barrel at the upper end. Price, $\$ 7.00$.

\section{5 \\ Lightning Compressed}

\section{THE NEW BRANDT SPRAYER}

No waste of time by stopping to pump it ahead. Can be done as the operator goes along.

For distributing Paris Green, Bordeaux Mixture, etc,

Will spray one or two rows of potatoes at a time as fast as a man walks. Will spray a row a mile long with only one filling of three gallons.

\section{PRICES-NOT PREPAID}

Brandt Sprayer, single nozzle

Brandt Sprayer, double and single nozzle...............6.50

Brandt Sprayer, tree attachment and both nozzles, complete...... 7.50

\section{THE LOWELL FOUNTAIN COMPRESSED-AIR SPRAYER}

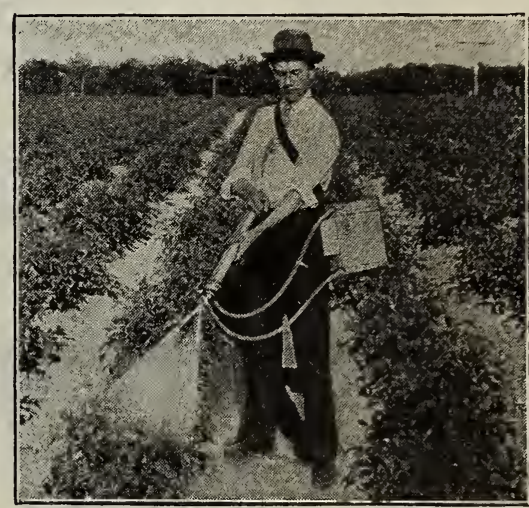

The New Brandt Sprayer

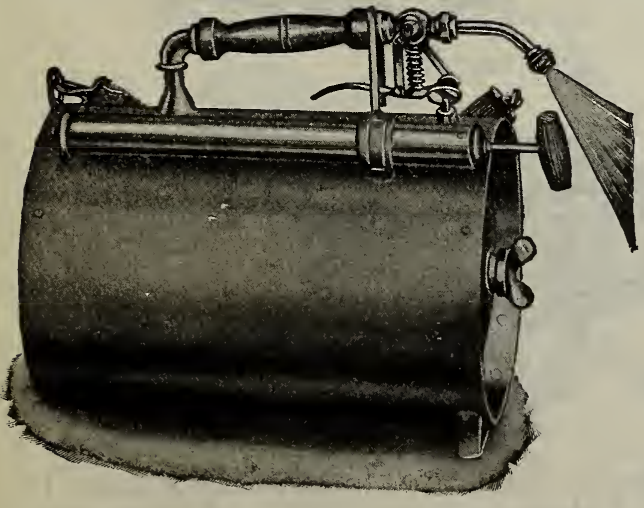

Lowell Fountain Sprayer No. 110, Galvanized Steel

New improvement, better than ever; it is devoid of complex or intricate parts; both automatic and positive in its action, it is so simple in construction that a child can operate. Capacity of tank three gailons; handy to carry, a shoulder strap with each machine. See cut, No. 110.

Complete with tree and vine attachment.............\$7.50

With vine attachment only................... 6.00

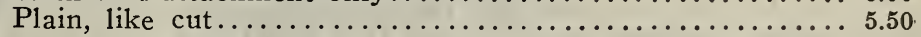

The vine attachment is made of brass with crookneck for spraying underneath the vines.

Brown's Auto Spray-This is one of the best Sprayers we carry and can only be appreciated by seeing it work. Price, complete, $\$ 6.00$.

No. 1, when properly charged, contains three gallons of solution and one gallon of compressed air. Eight to twelve strokes of the plunger will compress the air and two pumpings will discharge the entire contents. Three gallons of solution or one charge will easily cover one-quarter acre of potatoes or other similar crop.

We carry many Hand Sprayers, 50c, 75c. 


\section{LITTLE GIANT SPRAY PUMP NO. 1}

Constructed entirely of bräss; all labor is done on the downward stroke; provided with large air chamber and ball valves, so that the nozzle throws a continuous spray.

The best pump for spraying your chicken house, etc., with whitewash. Very strong and throws a steady spray. Price, each; $\$ 3.25$.

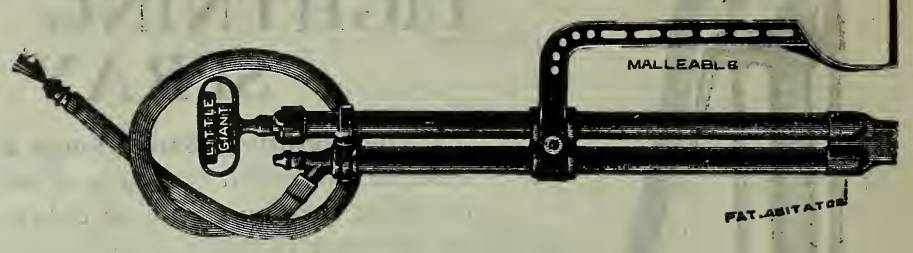

\section{LIGHTNING INSECT EXTERMINATOR}

Every household will have one when they know its value. It is adapted for all kinds of purposes, either for plants in the open field or house plants, shrubs, etc.; for spraying walls infested with insects, roosts of poultry houses, etc.

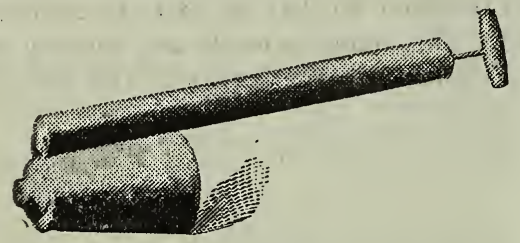

No. 104

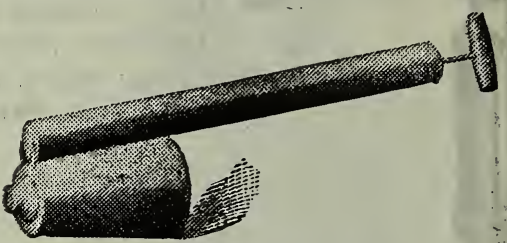

No. 108-Dust Sprayer

No. 104-Made of heavy tin, each...........\$0.50

No. 108 -Made of tin, price................ \$1.00

\section{SEED SOWERS}

\section{The Value of a Good Seed Sower is Almost Incalculable}

A good Seed Sower will pay for itself in sowing a few acres, both in the saving of seed, beside work is easily done, and in about one-fifth of the time that would be required to sow it by hand. Price, by express or freight, not prepaid

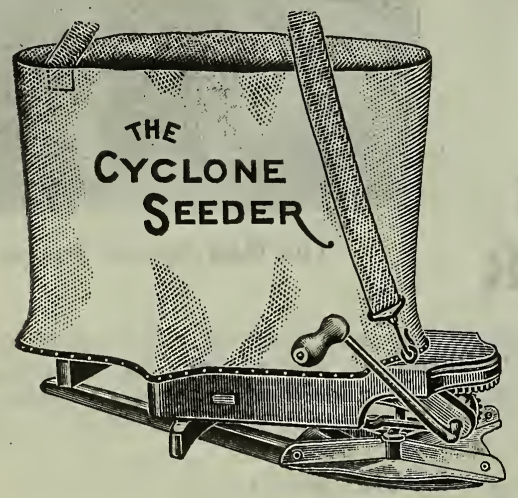

Cyclone-Differs materially and very advantageously from all other Sowers in having a slope feed board with an oblong hopper which terminates in a metal edge on which edge oscillates a feed plate which does not allow the seed to become clogged, but makes a positive force feed and insures a uniform flow and even distribution of seed. Price, $\$ 1.75$.

The Chicago Seeder, like the Cyclone, is a strictly first class machine, and will do equally well the same amount and kind of work. They differ only in the manner of operation, the Cyclone operating with a crank and the Chicago with a backward and forward movement of a "steel bow, through a swivel guide. This machine is sometimes called the "Fiddle Seeder." Price, $\$ 1.50$.
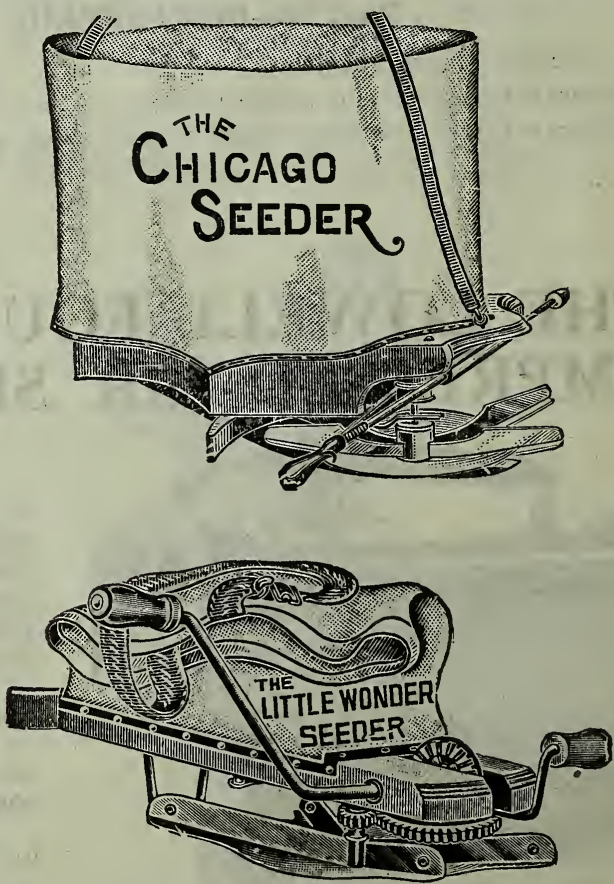

This illustration shows the Little Wonder Seeder. It has steel feed plate, oscillating device and spring-steel triangular bearings and adjustments. It will sow all varieties of field grain and seed, but is especially recommended for sowing grass seed. Price, \$1.25. 


\section{EXTRACTING THE ROOT It's Easy with a Cleveland Lawn Weeder}

75 Cents

Each
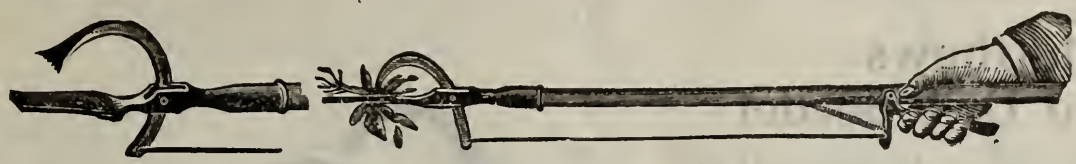

NO MORE BROKEN BACKS!

THIS LITTLE DEVICE GETS AT THE ROOT OF THE EVIL
75 Cents Each

The curved edge of the blade enters and loosens the soil, pressure on the lever then causes the toothed jaw to grasp the plant, and a slight pull suffices to dislodge it without disturbing the surrounding sod.

\section{Scollay Rubber Plant Sprinkler \\ BOTH STRAIGHT AND ANGLE NECK}

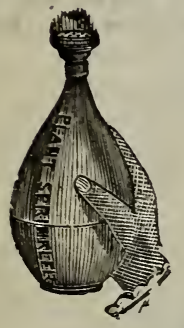

The Scollay Plant Sprinklers are made of rubber, with flat bottoms which admit of their standing upright when not in use. They can be used for sprinkling plants, cut flowers; also for dampening clothes, carpets and for disinfecting purposes.

Prices-(Add 10c postage if to go by mail)

No. 112 oz. capacity, each.................\$1.00

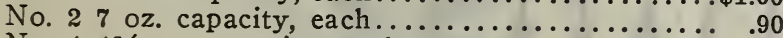

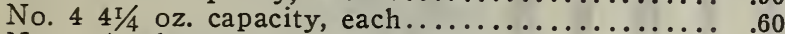

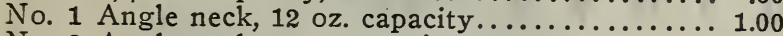

No. 2 Angle neck, 7 oz. capacity................. .90

\section{Scollay's Putty Distributor}

Price ...............................\$1.00 Liquid Glazing Putty, per $16-1 \mathrm{lb}$. can............... 1.50

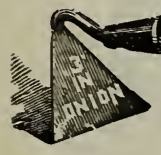

Onion Hoe

Jackson ..............\$0.25

Postpaid ..............35

Pruning Shears

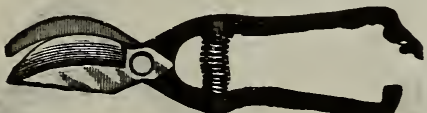

Henkel's - Three different sizes ...........\$1.00 each Pruning Shears-Common ............... .50 each Hedge Shears $\ldots \ldots \ldots \ldots \ldots \ldots \ldots \ldots \ldots \ldots \ldots \ldots \ldots .2 .00$ each

\section{Weeders}

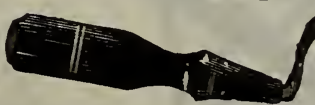

Weeder, Hazeltine...........\$0.25

Excelsior Weeder .................25

Postpaid, 10c extra.

\section{Plant Pot Labels}

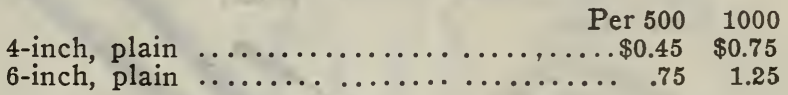

Wired Tree Labels $-3 \frac{1}{2} \times \mathbf{x} 5 / 8$, per $1,000 \ldots \ldots \ldots \ldots .25$

Cane Plant Stakes, per $100 \ldots \ldots \ldots \ldots \ldots \ldots \ldots \ldots . . \ldots 1.00$

The Little Giant (Mole Trap)-Self setting. No danger in setting this trap. Set by pulling up Plunger Rod. The trigger catches itself. Made of heavy cold rolled steel, thoroughly galvanized. The simplest, safest and strongest Mole Trap on the market. Price, $75 \mathrm{c}$.

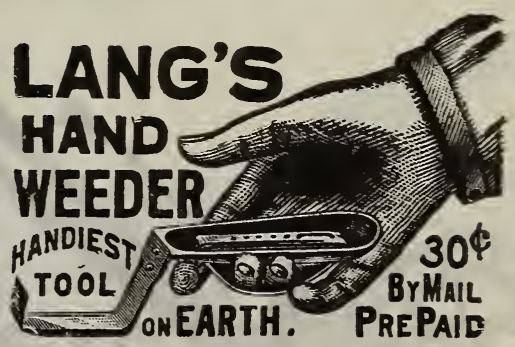

MAGNETIC HAMMERS-Each, 25c.

\section{Trowels}

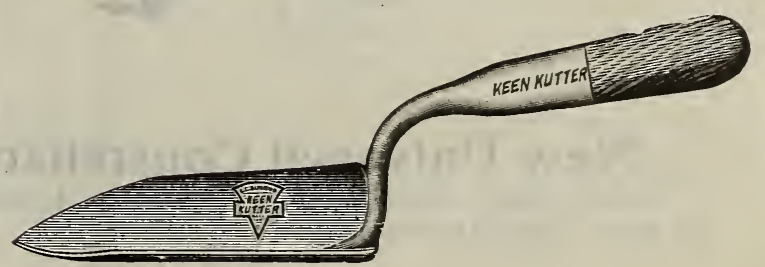

Steel, 6-inch ........................\$0.30

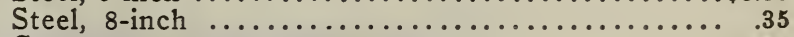

Common .......................... .25

\section{Dibber}

For transplanting; steel point..............\$0.30

Postpaid ..........................40 


\section{MATTHEWS NEW UNIVERSAL DRILLS, WHEEL HOES, HAND PLOWS, ETC.}

\section{Matthews Hill and Drill Seeder}

The same in style as the Garden Drill No. 17 , but is arranged so as to drop the seed either continuously in drill, or at distances of $4,6,8,12,16,24$ and 48 inches apart. The adjustment from drills to hills is made by one screw. The distance apart is regulated by the number of cogs on the driving wheel against which the agitator strikes. Price, boxed, $\$ 8.00$.

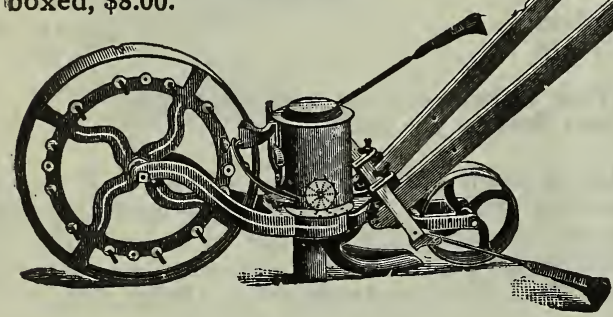

Sows all kinds of Vegetable Seeds, including peas, beans and corn. The depth may be gauged to any required space; will make a uniform deposit of the seed. It has a patent indicator bearing the names of different kinds of seeds, and conveniently located. Has the improved marker, and all late improvements (see cut). This drill opens the furrow, drops and covers the seed, rolls down the earth over it and marks the next row, all by simply pushing the machine forward. Price, boxed, $\$ 7.00$

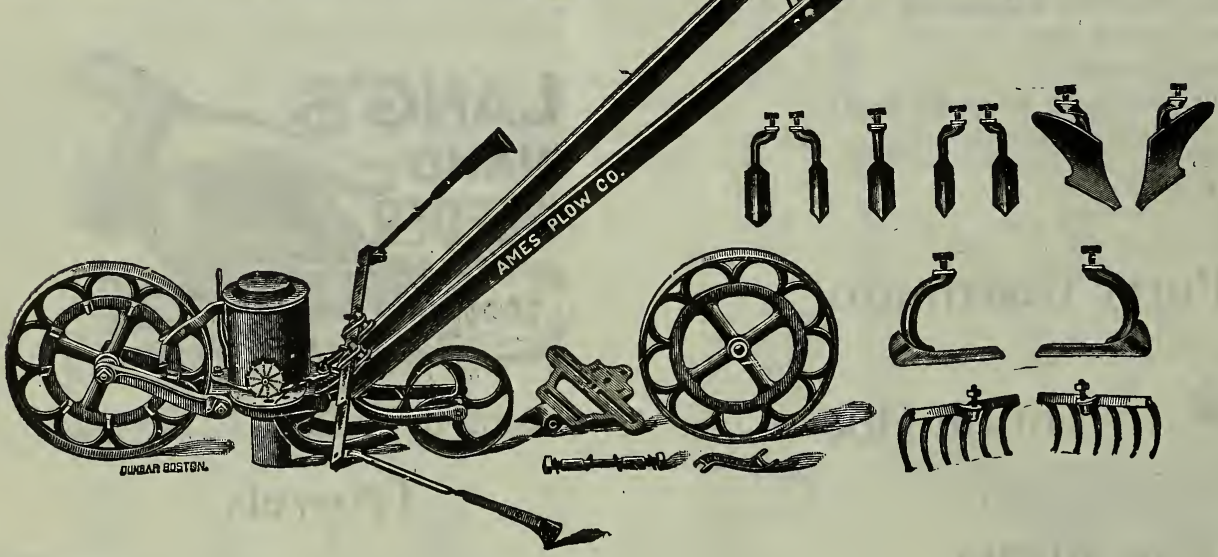

New Universal Constellation No. 19

Seeder, Hoe, Cultivator, Plow, Rake and Marker. The latest improved and most complete combination upon the market. Price, complete, $\$ 9.00$.

\section{The Easy Runner}

A Fine Cultivator for the small garden. Has a large wheel which makes it run very easily. Four special attachments: Plow, Rake, Cultivator. Shovel and Bull-Tongue.

Price, complete, $\$ 3.00$. 


\section{New Universal Double Wheel Hoe, Cultivator, Rake and Plow}

\author{
NO. 14-COMPLETE, AS SHOWN IN CUT \\ PRICE, BOXED, $\$ 6.00$
}

The attachments are: One pair Hoes, four Cultivator Teeth, one pair Plows, one pair Rakes and one pair Vine Guards.

\section{New Universal Double Wheel Hoe}

With One Pair of Hoes Only. The same machine as the New Universal Double Wheel Hoe, Rakes, Plows, Cultivator Teeth and Leaf Guards omitted.

\section{PRICE, BOXED, $\$ 3.75$}

We also carry carry a full line of 5 and 14-tooth Cultivators, Potato Planters, Diggers and Cutters, and All Hand Garden Tools. Prices on application.

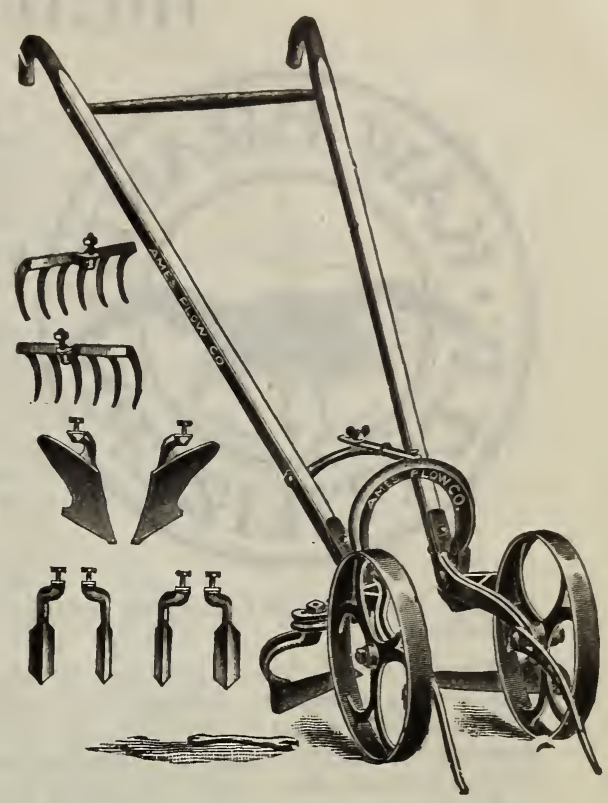

\section{The Keystone Weeder}

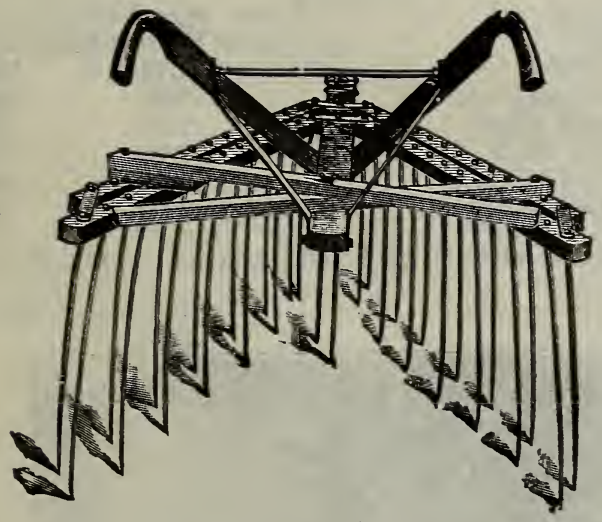

Narrowed to 30 inches.

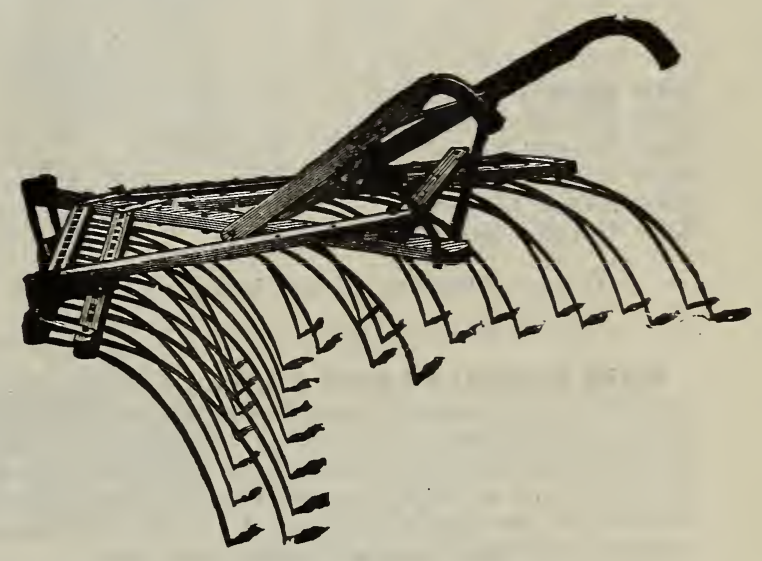

Expanded to $7 / 2$ feet.

The "Keystone Weeder" is the only weeder that is adjustable to any depth and width. It has no shafts that will hinder working close to the fence. It will not clog; the long, curved spring teeth are so placed and shaped that clogging is impossible. Twelve to fifteen acres can be covered in a day. It requires but one horse, and a boy can handle it. The teeth will not break. Price, $\$ 6.50$.

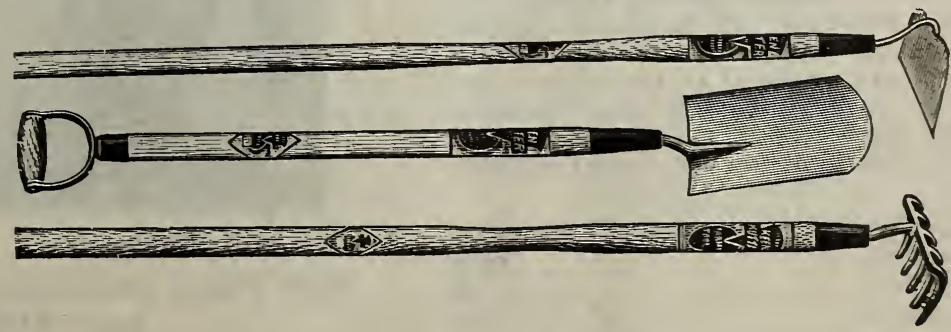




\section{HIGH GRADE FERTILIZER}

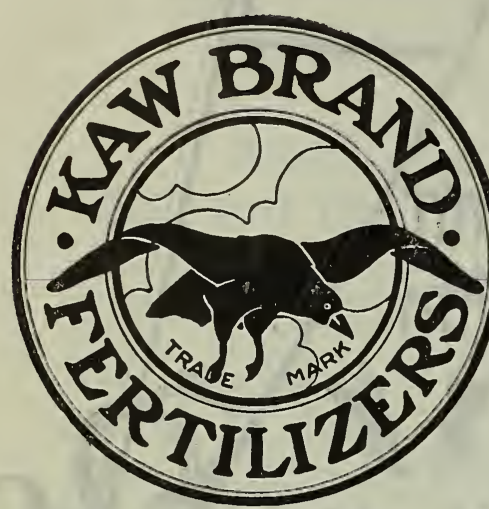

Next to good seeds there is nothing that repays the planter a larger percentage on the investment $t \mathrm{~h}$ a $\mathrm{n}$ go o d fertilizers. No difference what you plant, the stimulation of a crop will enable it to thrive under adverse circumstances and produce much heavier crops. We offer the we 11 known b r a nd, " $\mathrm{K}$ a w Brand" fertilizers.

Licensed in Missouri, Kansas, Oklahoma and Arkansas as follows:

Manufactured entirely from Stock Yards Manure, highly concentrated through patented process. One $100 \mathrm{lb}$. sack is equal to two tons of the richest unleached manure-properly balanced for different crops. No filler used; all plant food. No strong chemicals to burn and wear out your land. These are actual soil builders and root feeders.

\section{General Fertilizers}

Per 100 lbs.

Bone Flour ........................ \$2.50

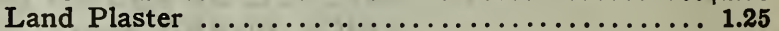

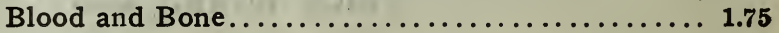

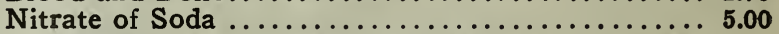

If wanted in larger quantities, ask for prices.

\section{Fertilizers}

Armour's Lawn Fertilizer-The first application should be made early in spring, or even in the winter, and again in June or July; do this before a shower, if possible.

Use 25 pounds to 1,000 square feet of surface. 25 -lb. package, $\$ 1.00 ; 50$ lbs., $\$ 1.50 ; 100$-lb. sack, $\$ 2.50$.

\section{Armour's Flower Food}

An excellent food for flowers and house plants, insuring a steady growth, healthy foliage and early bloom. $1 / 2$ lb. pkg., 15c; lb. pkg., 25c, not prepaid. If to go by mail, add $1 \mathrm{c}$ per ounce.

SPECIAL BOOKLET PERTAINING TO SCIENTIFIC FERTILIZATION OF ALL CROPS FREE POSTPAID UPON REQUEST.

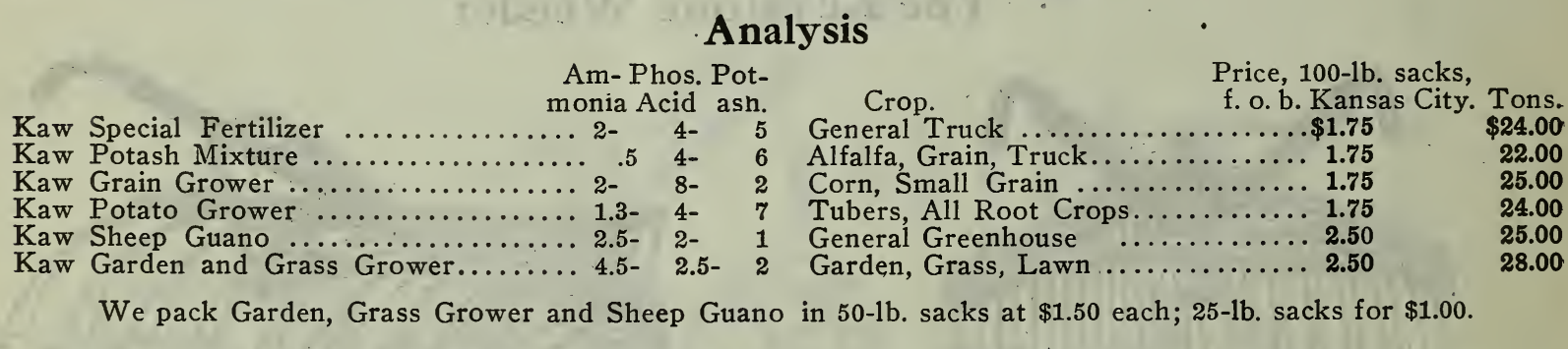

KAW BRAND PLANT FOOD-A delicacy for tender plants; producer of beautiful blossoms with fragrant scents. Will make their foliage luxuriant and greatly increase the flowering capacity of all plants. You can't afford to pot a single one without it. Put up in neat, convenient one-pound cartons at 41c each, postpaid; by express, customer paying charges, $25 \mathrm{c}$ each.

Will make close prices to parties ordering car lots and can assort car to suit customers.

\section{"Bonora," Nature's Plant Food}

The greatest discovery of modern times, liberally used and highly endorsed by the most prominent growers of the country, good for all kinds of plants, lawns, trees and any place where fertilizer can be used. Retains moisture, and enables the plants to withstand drouth. Contains all the elements essential to plant life, compounded in such a way as to give the most beneficial results. If you value your crop, lawn, shrubs or trees you cannot afford to be without this wonderful fertilizer -"Bonora."

Put up in dry form in all size packages as follows:

$1 / 4 \mathrm{lb}$., making 7 gallons................... $\$ 0.35$

1 lb., making 28 gallons.....................65

5 lb., making 140 gallons......................... 2.50

Circular and further information on application.

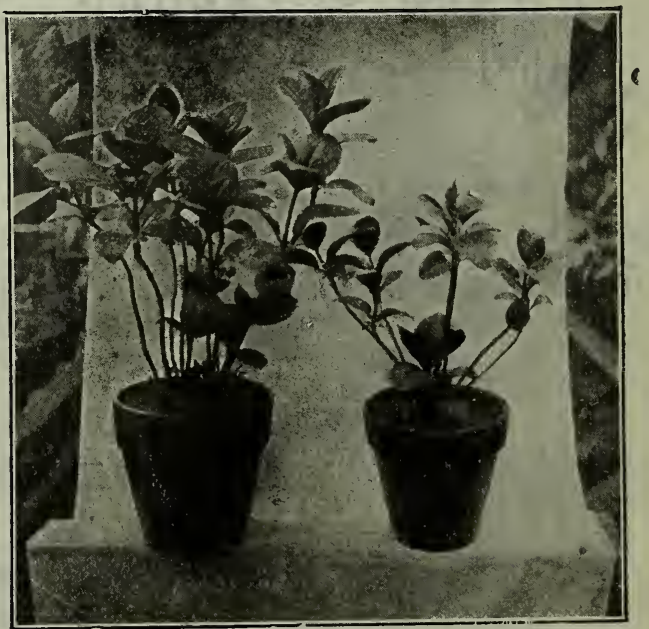

Treated with "Bonora."

Treated with Fertilizer.

These Plants Demonstrate the Results Obtained from "BONORA."

Both were the Same Size Before Treatment. 


\section{BEE-KEEPERS' SUPPLIES}

We will carry Bee Supplies at both stores, 505 Walnut and 1418 Grand Avenue. These goods are manufactured by the G. B. Lewis Co.

\section{DOVETAILED HIVES}

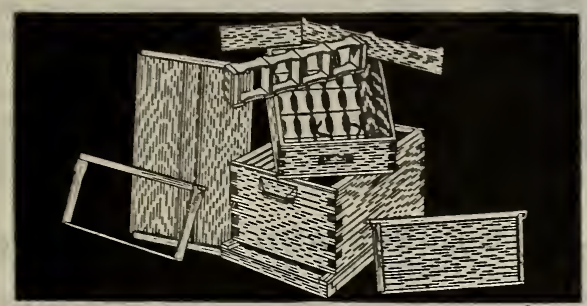

$1 \mathrm{x} / 2$-Story Hive, Open.

$1 \mathrm{I} / 2$ and 2-Story Hives, for Comb Honey. Not Including Section Boxes or Foundation Starters.

In Flat Inc. Nails

$$
*_{1} \dagger 1
$$

Hive Hive Hive Hives Hives

$11 / 2$-Story, 8 Frame......\$2.75 $\$ 2.50$ \$2.05 $\$ 9.50 \quad \$ 18.50$

$1 \mathrm{1} / 2$-Story, 10 Frame...... $2.90 \quad 2.65 \quad 2.20 \quad 10.25 \quad 20.00$

2 Story, 8 Frame....... $3.45 \quad 3.10 \quad 2.60 \quad 12.00 \quad 23.50$

2 Story, 10 Frame....... $3.65 \quad 3.30 \quad 2.80 \quad 13.00 \quad 25.50$

*Nailed and Painted. † Nailed Not Painted.

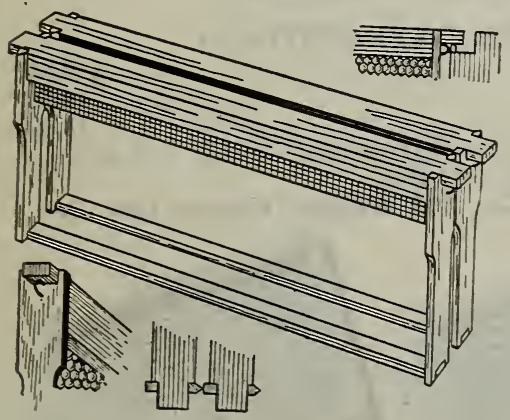

\section{BROOD FRAMES}

Self-Spacing Hoffman Frame.

Prices in Flat, including nails, 10 frames, $35 \mathrm{c} ; 100$ frames, \$\$.00.

\section{PRICE LIST OF COMB FOUNDATION}

In lots of ............. $1 \quad 5 \quad 10 \quad 25$ Medium brood ............... per lb. $\$ 0.57 \$ 0.55 \$ 0.53 \$ 0.51$ Light brood ...............per lb. $\quad .59 \quad .57 \quad .55 \quad .53$ $\begin{array}{lllll}\text { Thin surplus } \ldots \ldots \ldots \ldots \ldots & .5 & \\ \end{array}$ Extra thin surplus ........ per lb. $\quad .67 \quad .65 \quad .63 \quad .61$ Foundation by mail, $25 \mathrm{c}$ per lb. additional for postage.

\section{SIZE AND SHEETS PER POUND}

Medium brood ................161 $12 \times 73 / 4$

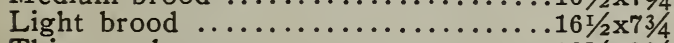

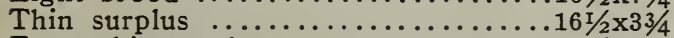

7 to 8

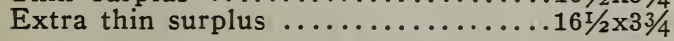
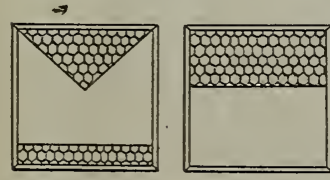

Fig. 1

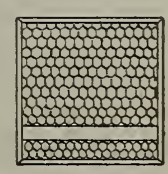

Fig. 3
Fig. 1 shows a section with three cornered starter on top and very narrow starter $(\mathrm{r} / 2$ inch) on the bottom.

Fig. 2 is another form of starter commonly used.

Fig. 3 is a section with narrow bottom starter and sheet on top, coming within $3 / 8$ inch of the same. This

method is considered most desirable and is used by many large bee-keepers.

If you wish to produce honey for the market, we would urge you to use both top and bottom starters, as you will thereby secure honey that will bear shipment much better.

\section{BINGHAM BEE SMOKERS}

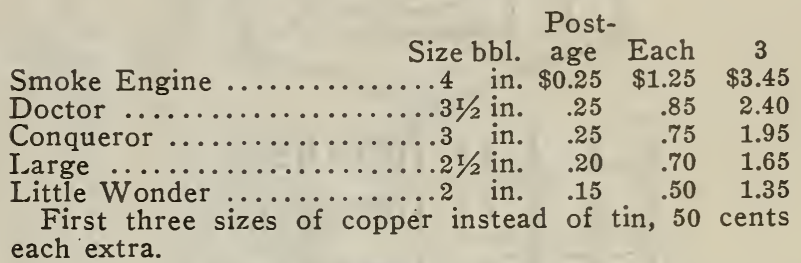

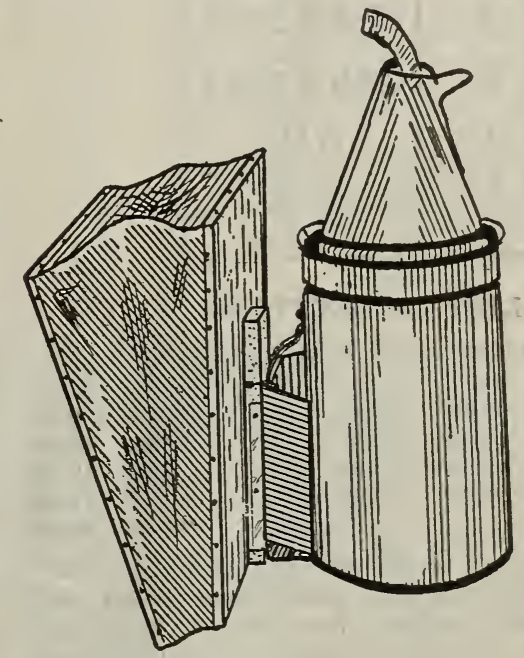

This is one of the very best styles of smoker we sell. It has b e e $n$ improved and is up to date in every respect, and if you are looking for a good article we highly commend the Bingham smoker. We have sold these for a good many years and never received a single complaint. These include all ne w im provements, direct draft, bent cap, wire handles, inverted bellows and soot burning device.

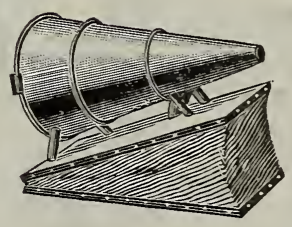

\section{CLARK SMOKER}

Each, 55c; 3 for $\$ 1.50$.

Postage, 20c each extra.

This is a Cold Blast Smoker, that is, the blast is forced from the tube in front of instead of through the fire.

\section{PRICE LIST OF SHIPPING CASES \\ With 3-Inch Glass, Nails and Paper}

In lots of .................... 10

To hold 12 sections, $4 \mathrm{r} / 4 \times 17 / 8$ or 2 in ........ $\$ 1.30 \quad \$ 11.50$

To hold 12 sections, $41 / 4 \times 11 / 2$ in. ........... $1.20 \quad 11.00$

To hold 12 sections, $4 \times 5 \times 13 / 8$ in. ............. 1.2011 .00

To hold 24 sections, $4 \frac{1}{4} \times 17 / 8$ or 2 in. ....... 2.0018 .00

To hold 24 sections, $41 / 4 \times 1 \quad$ in. .. $\quad \ldots . .1 .80 \quad 16.00$

To hold 24 sections, $4 \times 5 \times 13 / 8$ in. .......... 1.8016 .00

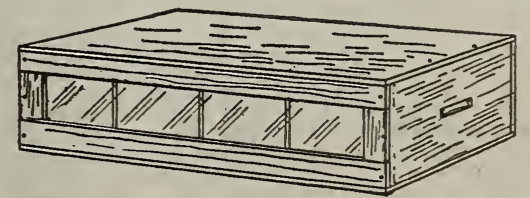

The above illustrates the 24-section case, with four sections to the front. 


\section{BEE-KEEPERS' SUPPLIES-Continued}

LEWIS 1-PIECE BRIGHT POLISHED SECTIONS

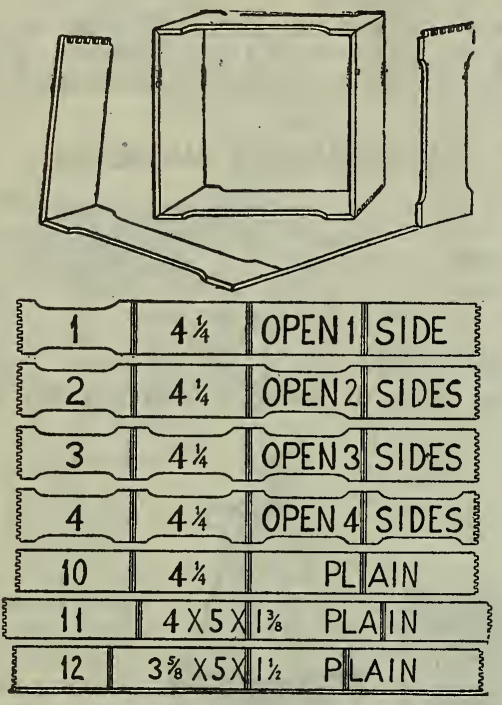

\section{PRICE LIST OF SECTIONS}

Regular size, $4 \frac{1}{4} \times 4 \frac{1}{4} / 4 \times 1 / 2$ to 2 inches wide.

No. 1 No. $2 \quad$ No. 1 No. 2

$100 \ldots \ldots \ldots . \$ 0.80 \quad \$ 0.70 \quad 2000 \ldots \ldots \ldots \$ 10.50 \$ 9.50$

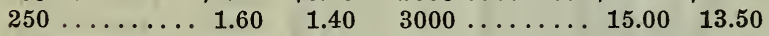

$500 \ldots \ldots \ldots \ldots 2.75 \quad 2.50 \quad 4000 \ldots \ldots \ldots 20.00 \quad 18.00$

$\begin{array}{lllllll}1000 & \ldots \ldots \ldots \ldots & 5.50 & 5.00 & 5000 \ldots \ldots \ldots \ldots & 23.75 & 21.25\end{array}$

$10000 \ldots \ldots \ldots \ldots \ldots \ldots \ldots \ldots \ldots \ldots \ldots .45 .00 \quad 40.00$

Plain sections, no bee-ways, 25c per 1000 less than above prices. Parties wanting more than 10000 will please write for special prices. Sections are regularly crated in lots of 500. Average weight of 1000 bee-way sections is 70 pounds and of plain sections 60 pounds.

\section{BEE PROTECTORS GLOVES}

Price, either style, large, medium or small, per pair, 50c. By mail, 57c.

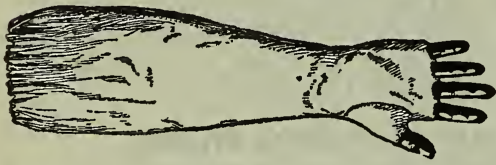

Canvas gloves with long sleeves, with or without fingers. These protect the hands as well as the wrists from stings. An improvement in canvas gloves has been made this season. The canvas is prepared in such a way as to make the glove practically sting-proof.

GLOBE BEE VEIL

Sent by mail for $\$ 1.00$; extra nets, 60 cents each.

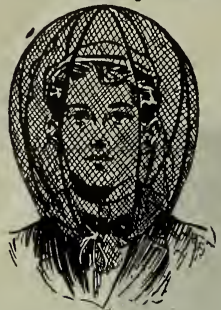

ALLEY'S Perforated Zinc Style Each, $45 \mathrm{c} ; 10, \$ 4.00$. By mail, $15 \mathrm{c}$ each extra.

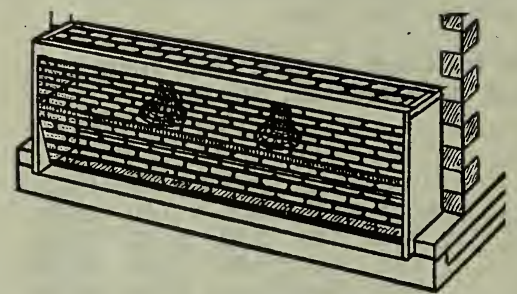

This is designed to catch and cage the drones in an apartment by themselves. They can then be carried to another apiary, or be destroyed, as circ u $\mathrm{m}$ s $\mathrm{t}$ a nces require. The trap will also catch the queen when a swarm issues, and hold her confined until the swarm comes back.

\section{HONEY EXTRACTORS}

The Novice $\ldots \ldots \ldots \ldots \ldots \ldots \ldots \ldots \ldots \ldots \ldots \ldots \ldots .50$

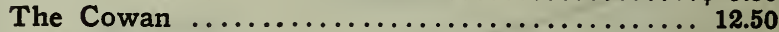

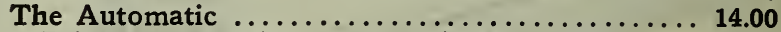

Prices on anything not mentioned in this list will be made you on request. Address

The Harnden Seed Co., 505 Walnut, Kansas City, Mo.
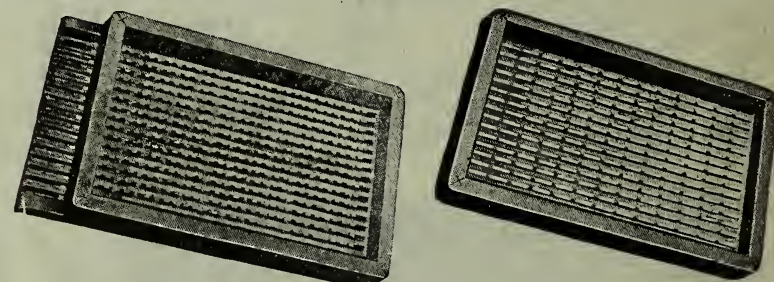

HAND SEED CORN GRADER-The most useful and necessary implement a corn grower can have. The Planters Patent Grader works like a charm. It gives you a good stand-that means more corn, more money. No corn planter can drop grains that are not regular. Order one of these graders. We have either the single or double screens, like cut. Prices: Single screen, $\$ 1.00$; Double screen, $\$ \mathbf{1 . 5 0}$. Write for pamphlet giving further particulars.

TO OUR CUSTOMERS. For 25 years we have been working on the seed trade in Kansas City, and each year has shown a material growth in our business. We have tried at all times to send out the very best seeds obtainable, both in this country and Europe, testing everything that goes out and watching very carefully the products that are brought on our market here each year. By this means we are able to give our customers the benefit of our experience both as to the very best varieties to plant and the kinds that mature most favorably in this climate. We believe we are in position to give our customers better service than they can obtain by buying from Eastern houses. A novelty is never sent out until it has been thoroughly tested by us and proven to do well in this climate, producing a good crop and selling well on our market. To our market gardener friends who buy in large quantities, if they will write us sending the quantity they require, we will send them our special price list to market gardeners. We wish especially to call the attention of our customers to flower seeds and spring bulbs. We find that this trade is increasing as the cnuntry grows older. We carry a large stock of choice varieties of flower seeds, bulbs and shrubs which we import direct from Holland and other European countries.

TO OUR CUSTOMERS IN THE CITY. We have established an up-town store, 1418 Grand Ave., where we carry all kinds of seeds, poultry supplies, bee supplies, chicken feed, fertilizer and everything needed by a city gardener, Our 'phones at the new store will be 1618 Grand, Bell, and 1617 Main, Home. Address all mail to 505 Walnut St. Our'phone number at the office is 1618 Main, both 'phones. We thank you for the liberal patronage you have extended us in the past and trust that we shall merit your trade in the future. 
THE HARNDEN SEED CO., KANSAS CITY, MO.

\section{USEFUL INFORMATION.}

Quantity of Seed Required for a Given Number of Hills.

Pole Beans

Corn ................... qt. to 200

Cucumber............... oz. to 50

Watermelons ............. oz. to 30

Muskmelons .............2 oz. to 60

Pumpkins ................ oz. to 20

Squash................. oz. to 30

Okra .................. oz. to 100

Quantity of Seed Required for a Given

Feet of Drill

Asparagus . . . . . . . . . . . . 50

Beet .................... oz. 60

Beans, Dwarf . . .............. pt. 60

Carrot .................... oz. 100

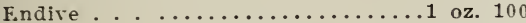

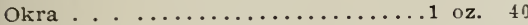

Onions .................. oz. 50

Onion Sets . . . . . . . . $20 \ldots \ldots \ldots 1$ pt. 20

Parsley . . . .................... oz. 100

Parsnins . . ................. oz. 100

Peas ................... pt. 50

Radishes . . . . . . . . . . . . . 1 oz. 100

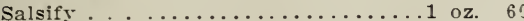

Spinach . . . . . . . . . . . 100

Turnip

1 oz. $15 n$
Quantity of Seed Required for a Given

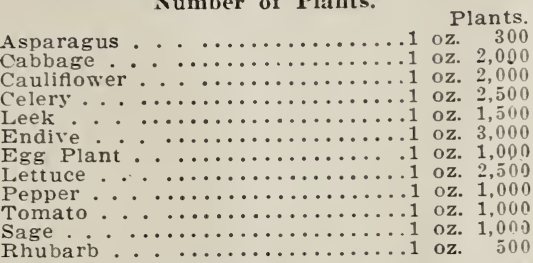

Weights Per Bushel and Amounts of Seed sown to the scre.

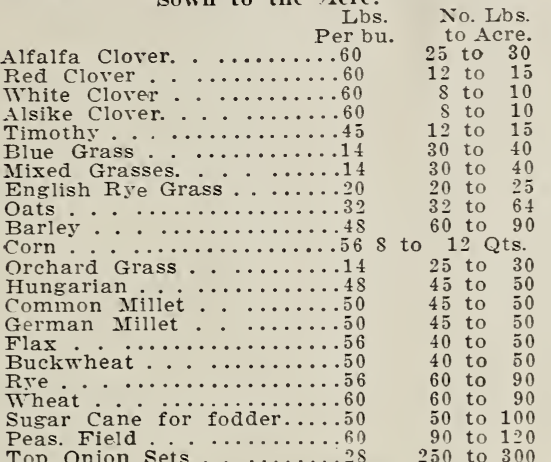

Top Onion Sets
Dwarf Beans

Early Peas

Marrowfat Peas

Beets

Mangel Wurzel

Carrots

Onions

Onions for Sets

Onion Sets

Parsnips

Radishes

Rutabaga

Spinach

Salsify

In Drills.

No. Lbs. to Acre

- 75 to 98

0 to 80

\section{Maturity Table.}

Beans, table use

Cabbage, early f........... 50 to 70 days

Cabbage, late for cutting...100 to 120 days Carrots, table use Celery, table use........120 to 140 days Sweet Corn, table use.....6.65 to so days Lettuce, table use. .....4 40 to 50 days

Irelons, table use

Onions for storage

Peas, table use

Radishes, tahle use

Tomato, table use

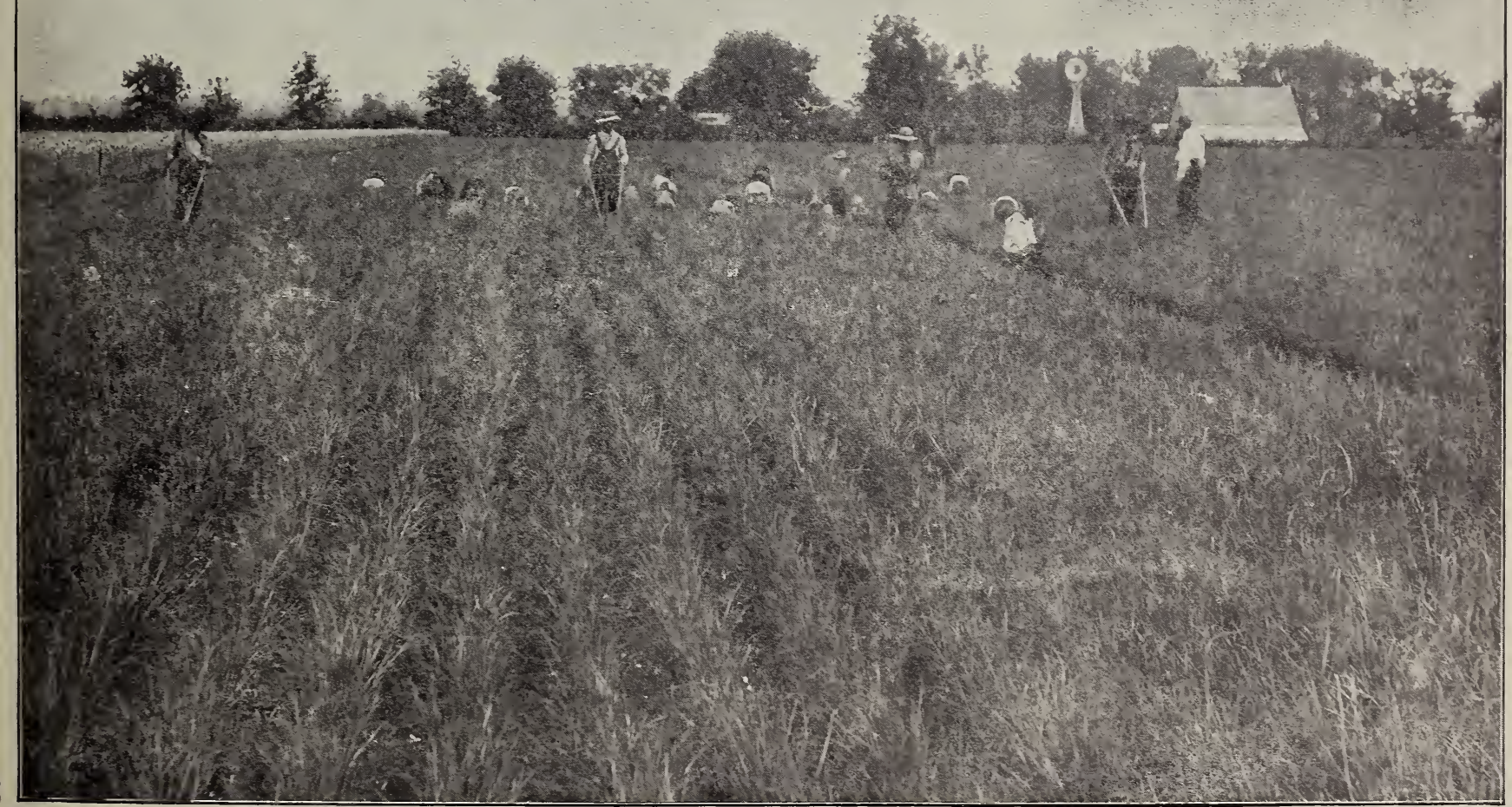




\section{Field, Garden \\ and FlowER \\ SEEDS}

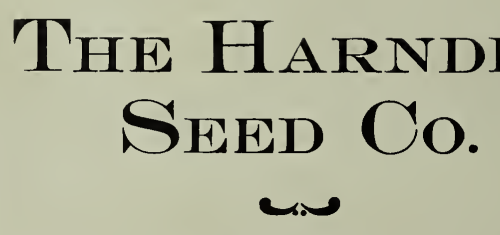

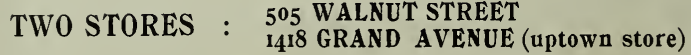

Kansas City, Mo. 